\title{
WestVirginiaUniversity
}

THE RESEARCH REPOSITORY @ WVU

Graduate Theses, Dissertations, and Problem Reports

2014

\section{Three Essays on Trading by Members of Congress}

Serkan Karadas

West Virginia University

Follow this and additional works at: https://researchrepository.wvu.edu/etd

\section{Recommended Citation}

Karadas, Serkan, "Three Essays on Trading by Members of Congress" (2014). Graduate Theses,

Dissertations, and Problem Reports. 421.

https://researchrepository.wvu.edu/etd/421

This Dissertation is protected by copyright and/or related rights. It has been brought to you by the The Research Repository @ WVU with permission from the rights-holder(s). You are free to use this Dissertation in any way that is permitted by the copyright and related rights legislation that applies to your use. For other uses you must obtain permission from the rights-holder(s) directly, unless additional rights are indicated by a Creative Commons license in the record and/ or on the work itself. This Dissertation has been accepted for inclusion in WVU Graduate Theses, Dissertations, and Problem Reports collection by an authorized administrator of The Research Repository @ WVU.

For more information, please contact researchrepository@mail.wvu.edu. 


\title{
Three Essays on Trading by Members of Congress
}

\author{
by \\ Serkan Karadas \\ Dissertation submitted to the \\ College of Business and Economics \\ at West Virginia University \\ in partial fulfillment of the requirements \\ for the degree of \\ Doctor of Philosophy \\ in \\ Economics \\ Stratford Douglas, Ph.D., Chair \\ Joshua Hall, Ph.D. \\ Alexander Kurov, Ph.D. \\ Harry Turtle, Ph.D. \\ Ronald Balvers, Ph.D., Chair \\ Department of Economics \\ Morgantown, West Virginia \\ 2014
}

Keywords: informed trading, insider trading, congressional trading, STOCK Act

Copyright 2014 Serkan Karadas 


\section{Abstract}

\section{Three Essays on Trading by Members of Congress}

\section{Serkan Karadas}

My dissertation examines the information content of stock trades by members of Congress (politicians) in three separate essays. In my first essay, based on approximately 62,000 common stock transactions over the 2004-2010 period, I present evidence that past firm-level trading activity by politicians predicts future firm-level stock returns, and this prediction is stronger for the pre-recession period and for small firms. By constructing buy-minussell transactions-based portfolios, I document that the portfolios of Republicans outperform those of Democrats. Also, being a powerful member of Congress is associated with substantially higher abnormal returns for Republicans, but not for Democrats. Among powerful Republicans, the portfolios of unsophisticated traders perform significantly better than those of sophisticated ones with abnormal returns exceeding $34 \%$ on annual basis under one-week holding period. The abnormal returns in general disappear beyond three-month holding period suggesting that politicians trade on time-sensitive value-relevant information. This study contributes to the literature showing that power, party membership, and investor sophistication are important determinants of the abnormal returns in congressional stock portfolios.

In my second essay, I, for the first time in the literature, separately examine the performance of common stock transactions of politicians and their family members (spouses and dependent children). I document that the transactions by both politicians and spouses contain value-relevant information, but the content of information is less time-sensitive for spouses. On the other hand, the transactions in the accounts of the dependent children perform very poorly. I also present evidence that the transactions in tax-deferred accounts such as 401(k)s contain less information than those in taxable trading accounts for both politicians and their spouses. I finally show that the portfolios of the powerful politicians' spouses outperform those of the non-powerful politicians' spouses. These results suggest that members of Congress take advantage of their informational advantage trading through the accounts of their spouses.

My third essay examines the properties of aggregate congressional trading. I investigate the ability of aggregate trading activity by members of Congress to predict stock market returns using 77,663 stock transactions over the 2004-2010 period. I find that aggregate congressional trading predicts excess market returns 2 to 3 months in advance. These findings imply that politicians, similar to corporate insiders, trade on information containing macroeconomic components. 


\section{Dedication}

To my wife, Minh Tam Tammy Schlosky, who has always supported me and never stopped believing in me.

To my parents, Riza and Kadriye Karadas, who have always prayed for me.

To my aunt, Gulfiye Gerin, who was very proud of me and was as close to me as my own mother, but could not share my happiness at this stage of my life due to terminal cancer. 


\section{Acknowledgements}

The past five years that I spent at West Virginia University transformed me from a shy undergraduate student to a passionate teacher and scholar. I owe the biggest part of this change to my advisors and dissertation chairs, Dr. Ronald Balvers and Dr. Stratford Douglas. They helped me become an independent scholar, and always encouraged me when I had out-of-the-box ideas. Even though he spent the last two years at McMaster University, Dr. Balvers never let me feel that he was further away from me. He patiently read through my pages long e-mails and helped me get through challenging times with his unmatched intuition and guidance. Despite having so many other commitments, Dr. Douglas did not hesitate to advise me. His friendly attitude and critical reasoning ensured that I made significant progress in my dissertation.

I am also very thankful to the other members of my dissertation committee: Dr. Joshua Hall, Dr. Alexander Kurov, and Dr. Harry Turtle. Dr. Hall has been my mentor ever since I started studying in the US. He is one of the biggest reasons why I chose West Virginia University to get my doctoral degree. Dr. Kurov always met with a smile on his face, and I always enjoyed exchanging ideas with him. I learned so much from him as a young scholar. Despite not knowing me at first, Dr. Turtle was happy to help me with my dissertation. I always valued his input at every stage of my research.

I also owe a great amount of gratitude to Dr. Feng Yao, Dr. Arabinda Basistha, and Dr. Ann Marie Hibbert for giving me guidance at the times I was confused the most. I discovered my passion for teaching at West Virginia University. This discovery was possible thanks to Dr. Clifford Hawley who assigned me challenging and great courses to teach.

The best thing that happened to me at the graduate school was that I found the love of my life: Minh Tam Tammy Schlosky. She has kept me motivated all these years, and has loved me unconditionally. Tammy's parents, George Schlosky and Suong Schlosky, have made such a big difference in my life that I never felt alone in the US. Having their support and blessings helped me make so much progress in my personal and professional life. Despite thousands of miles between us, my parents, Riza and Kadriye Karadas, and my siblings, Mehmet Karadas, Ahmet Karadas, and Bedriye Ceven have always made sure that I was motivated to accomplish my dreams. Having their unconditional support gave me peace of mind and motivation in the last seven years I spent in the US.

The friends that I have met at West Virginia University and Beloit College, Dr. Ismail Celik, Perihan Celik, Dr. Neal Newfield, Dr. Susan Newfield, Eugene Bempong, Seydina Sene Ousmane, Jorida Papakroni, Kirill Temlyakov, Durga Gautam, Patrick Manzi, Will McAndrew, Danko Tarabar, and Ilija Bojovic made such a big difference in my life that I feel blessed to have met them. 


\section{Contents}

1 Introduction $\quad 1$

2 Informed Trading at Capitol Hill: Evidence from Congressional Trading 3

2.1 Introduction . . . . . . . . . . . . . . . . . 3

2.2 Literature Review . . . . . . . . . . . . . . . . . . . . . 7

2.3 Hypotheses . . . . . . . . . . . . . . . . . . . . . . . . . . . . . . . . . . . . . . . .

2.3.1 Predictive Ability . . . . . . . . . . . . . . . . . . . . 12

2.3.2 Abnormal Returns . . . . . . . . . . . . . . . . 13

2.4 Data . . . . . . . . . . . . . . . . . . . . . . 15

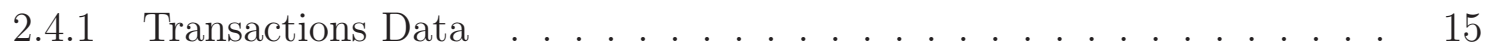

2.4 Committee Data . . . . . . . . . . . . . . . . 16

2.5 Firm-Level Analysis: Panel Data Approach . . . . . . . . . . . . . . . . . . 17

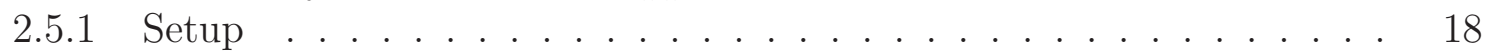

2.5.2 Main Results ... . . . . . . . . . . . . . . . . 20

2.5.3 Longer Time Horizon . . . . . . . . . . . . . . . . . . . . . . . 20

2.5.4 Is Information Related to Firm Size? . . . . . . . . . . . . . . . . . . 21

2.5.5 Subperiod Analysis around the Great Recession . . . . . . . . . . . . 21

2.5.6 Trades in Illiquid Stocks . . . . . . . . . . . . . . . . . . . . . 22

2.5.7 Limitations . . . . . . . . . . . . . . . . . . . . . . . . . . . . . . . . . . . . .

2.6 Calendar-Time Portfolio Analysis . . . . . . . . . . . . . . . . . . . . 23

2.6.1 Empirical Motivation . . . . . . . . . . . . . . . . 23

2.6.2 Two Choices for Calendar-Time Portfolios . . . . . . . . . . . . 25

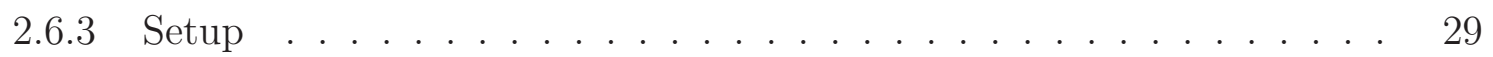

2.6.4 Measuring Abnormal Returns . . . . . . . . . . . . . . . . 31

2.6.5 Main Results . . . . . . . . . . . . . . . . . . . . . . 32

2.6.6 Party Memberships . . . . . . . . . . . . . . . . . . . . . . . . . . . . . . 33

2.6.7 Powerful Politicians . . . . . . . . . . . . . . . . . . . 34

2.7 Information versus Skill . . . . . . . . . . . . . . . . . . . 35

2.8 Transaction Size Relative to Net Worth . . . . . . . . . . . . . . . . . 37

2.9 Is It Really Power? . . . . . . . . . . . . . . . . . . . . . . . . . . . . . . . . . . . . . . . . . . . . . .

2.10 Is It Really Party Membership? . . . . . . . . . . . . . . . . . . . . . . . . . 39

2.11 Is It Really Private Political Information? . . . . . . . . . . . . . . . . . . 41

2.12 Conclusion . . . . . . . . . . . . . . . . . . 43 
3 Informed Trading through Family Members: Evidence from Congressional Trading 62

3.1 Introduction . . . . . . . . . . . . . . . . . . . . . . . . . 62

3.2 Hypotheses . . . . . . . . . . . . . . . . . . . . . . . . . 65

3.3 Data . . . . . . . . . . . . . . . . . . . . 66

3.4 Event Analysis and Results . . . . . . . . . . . . . . . . . . 67

3.4 .1 Setup . . . . . . . . . . . . . . . . . . . 68

3.4.2 Results . . . . . . . . . . . . . . . . . . . . . . . . . 69

3.5 Transactions-Based Calendar-Time Portfolios . . . . . . . . . . . . . . . 69

3.5.1 Portfolio Construction . . . . . . . . . . . . . . . 70

3.5.2 Alphas on the Long/Short Portfolios . . . . . . . . . . . . . . . 71

3.5.3 Portfolio Performance of Four Different Account Types . . . . . . . . 72

3.5.4 Investments through Taxable versus Tax-Deferred Trading Accounts . 73

3.5.5 Powerful Family Members . . . . . . . . . . . . . . . . . . . 75

3.6 Direct Comparison Between Politicians and Their Spouses . . . . . . . . . . 75

3.7 Spouses of Type II Politicians versus Spouses of Type III Politicians . . . . . 76

3.8 Conclusion . . . . . . . . . . . . . . . . . . . . . . . . . . . . 77

4 Aggregate Congressional Trading and Stock Market Returns $\quad 95$

4.1 Introduction . . . . . . . . . . . . . . . . . . . . . . . . 95 95

4.2 Legal Framework and the STOCK Act . . . . . . . . . . . . . . . 98

4.3 Literature Review and Hypothesis Development . . . . . . . . . . . . . 100

4.3.1 Politicians and Stock Returns: Political Investment . . . . . . . . . 100

4.3.2 Corporate Insiders and Market Returns . . . . . . . . . . . . . . . . 102

4.3 .3 Hypothesis Development . . . . . . . . . . . . . . . . . . . . . 102

4.3.4 Research Question and Hypotheses . . . . . . . . . . . . . . . 105

4.4 Data and Aggregate Congressional Trading . . . . . . . . . . . . . . 106

4.4 .1 Raw Data . . . . . . . . . . . . . . . . . . . . . . . 106

4.4 .2 Data Description . . . . . . . . . . . . . . . . . . . 108

4.4.3 Measure of Aggregate Congressional Trading . . . . . . . . . . . . . 109

4.5 Empirical Analysis and Results . . . . . . . . . . . . . . . . . . 110

4.5.1 Descriptive Statistics of Variables . . . . . . . . . . . . . . . 111

4.5 .2 Baseline Regression . . . . . . . . . . . . . . . . . . . . . . . . 111

4.5 .3 Macroeconomic Variables . . . . . . . . . . . . . . . . . . . . . . . 113

4.5.4 Industry-Level Returns . . . . . . . . . . . . . . . . . . . . . . 114

4.6 Subgroup Analysis: Chambers and Parties . . . . . . . . . . . . . . 116

4.7 Robustness Check . . . . . . . . . . . . . . . . . . . . . . . . . . . . 118

4.8 Conclusion and Policy Implications _ . . . . . . . . . . . . . . . 119

5 Conclusion 132

$\begin{array}{ll}\text { References } & 134\end{array}$ 


\section{List of Tables}

2.1 Descriptive Statistics . . . . . . . . . . . . . . . . . . . . . . . . 44

$2.2 \quad$ Firm-Level Prediction . . . . . . . . . . . . . . . . . . . . . . . . 45

2.3 Firm-Level Prediction: Sub-Period Analysis . . . . . . . . . . . . 46

2.4 Firm-Level Prediction: Illiquidity Filtered _ . . . . . . . . . . . . 47

2.5 Alphas on Long/Short (Buy-Minus-Sell) Portfolio: Full Sample . . 49

2.6 Number of Transactions and Traders . . . . . . . . . . . . . . . . 50

2.7 Republicans . . . . . . . . . . . . . . . . . . . . . . 51

2.8 Democrats . . . . . . . . . . . . . . . . . . . . . 52

2.9 Powerful Republicans _. . . . . . . . . . . . . . . . . . 53

2.10 Powerful Democrats _. . . . . . . . . . . . . . . . . . . 54

2.11 Sophisticated Powerful Republicans _ . . . . . . . . . . . . 55

2.12 Unsophisticated Powerful Republicans . . . . . . . . . . . . . . 56

2.13 Unsophisticated Powerful Republicans: Tercile Analysis . . . . . . . 57

2.14 Powerful Republicans: Power and Pre/Post-Power Years . . . . . . 58

2.15 Majority Control, Party Membership, and Portfolio Performance . 59

2.16 President's Party, Party Membership, and Portfolio Performance . 60

2.17 Connected and Non-Connected Portfolios . . . . . . . . . . . . 61

3.1 Politician Types and Number of Transactions _ . . . . . . . . . . 79

3.2 Descriptive Statistics _. . . . . . . . . . . . . . . . . . . . . . . 80

3.3 Politicians Only . . . . . . . . . . . . . . . . . . . . . . . . . . . 83

3.4 Spouses Only . . . . . . . . . . . . . . . . . . . . . . . . . . . . . 84

3.5 Dependent Children Only . . . . . . . . . . . . . . . . . 85

3.6 Joint Portfolios Only . . . . . . . . . . . . . . . . . . . . 86

3.7 Politicians' Retirement Portfolios _ . . . . . . . . . . . . . . 87

3.8 Politicians' Trust Portfolios . . . . . . . . . . . . . . . . . . . 88

3.9 Politicians' Portfolios (Excluding Trust Transactions) . . . . . . . 89

3.10 Powerful Spouses _. . . . . . . . . . . . . . . . . . . . 9 90

3.11 Nonpowerful Spouses . . . . . . . . . . . . . . . . . . . . . . . . . . . 91

3.12 Politicians' Paired Portfolios . . . . . . . . . . . . . . . . . . 92

3.13 Spouses' Paired Portfolios (Spouses of Type II Politicians) . . . . . 93

3.14 Spouses of Type III Politicians . . . . . . . . . . . . . . . . . . 94

4.1 Types of Securities in the Final Sample . . . . . . . . . . . . . . . 121

4.2 Dollar Amounts of Transactions by Politicians . . . . . . . . . . . 123

4.3 Top Ten Traders During the 2004-2010 Period . . . . . . . . . . . 124 
4.4 Breakdown of Transactions by Chamber and Party Affiliations . . 125

4.5 Descriptive Statistics . . . . . . . . . . . . . . . . . . 126

4.6 Aggregate Congressional Trading and Excess Market Returns . . . 127

4.7 Industry Level Congressional Trading and Excess Market Returns 128

4.8 U.S. House and U.S. Senate . . . . . . . . . . . . . . . . . . . . . . . . 129

4.9 Democrats (Dems) and Republicans (Reps) . . . . . . . . . . . 130

4.10 Aggregate Congressional Trading and Excess Market Returns . . . 131 


\section{List of Figures}

2.1 Calendar Time Portfolio Chart . . . . . . . . . . . . . . . 48

3.1 CARs on the Long/Short (Buy-Minus-Sell) Transactions . . . . . . 81

3.2 Calendar Time Portfolio Chart . . . . . . . . . . . . . . . 82

4.1 Person-Based Trading Index (PTI) . . . . . . . . . . . . . . . 122 


\section{Chapter 1}

\section{Introduction}

Members of Congress (politicians) have been required to report their financial transactions since the late 1970s. This requirement was put in place in order to rebuild public confidence in Congress following the Watergate era scandals. ${ }^{1}$ Ziobrowski et al. (2004; 2011) conducted two influential studies examining the performance of common stock investments by members of Congress over the 1985-2001 period. They revealed that the portfolios of Senators and Representatives outperformed the market during their sample period. These interesting findings have fueled a debate on whether members of Congress should be allowed to trade stocks, and if they are allowed, what limits and rules they should be subject to. Congress passed the Stop Trading on Congressional Knowledge Act (STOCK) of 2012 to increase transparency on congressional stock trades and to clearly forbid members of Congress from trading on inside information. Eroding public trust in Congress was a key factor in passing the STOCK Act after it was first proposed by Representatives Brian Baird and Louise M. Slaughter in $2006 .^{2}$

In the signing ceremony of the STOCK Act, President Obama hailed the STOCK Act as the right step to repair a deficit of trust between Congress and the public. ${ }^{3}$ Prior to the STOCK Act, members of Congress were required to submit financial disclosure reports once

\footnotetext{
${ }^{1}$ http://www.washingtonpost.com/wp-srv/national/longterm/watergate/legacy.htm

${ }^{2}$ http://www.nytimes.com/2012/03/23/us/politics/insider-trading-ban-for-lawmakers-clearscongress.html?.r=0

${ }^{3}$ http://www.cnn.com/2012/04/04/politics/stock-act-signing/
} 
a year on the financial transactions that they undertook in the previous year. The STOCK Act required that members of Congress post their trades online within 2 to 3 months of the transaction date to enhance transparency. Nevertheless, Congress amended the STOCK Act in 2013 by abandoning online posting requirement due to national security and identity theft concerns following a study by the National Academy of Public Administration. ${ }^{4}$

There is now an ongoing debate on the way that members of Congress trade stocks. Nevertheless, the information content of congressional stock trades is not well-known. We hope to shed light on this issue by studying different aspects of congressional trading. In the first essay (Chapter 2 of this dissertation), we investigate the information content of congressional trading at the firm- and portfolio-level, and find that the past firm-level trading activity by politicians predicts future firm-level stock returns. Also, the portfolios of Republicans earn short-term abnormal returns while there is almost no evidence of informed trading for Democrats. The second essay separately examines the presence of informed trading for politicians and their family members. We present evidence that the spouses of politicians are also informed traders. Furthermore, the portfolios of powerful politicians' spouses outperform those of non-powerful politicians' spouses. In the third essay, we analyze the aggregate properties of congressional trading, and document that aggregate congressional trading predicts stock market returns suggesting that there is also a macroeconomic component in congressional stock trades.

The findings in this dissertation suggest that members of Congress are informed traders, and they share private political information with their spouses. Also, members of Congress trade on both firm-specific and macroeconomic information. The information in congressional stock trades has a very time-sensitive nature, only capable of predicting stock returns and generating abnormal returns in the short-time periods (up to three months).

\footnotetext{
${ }^{4}$ http://www.napawash.org/2013/1453-stock-act-impact-of-providing-personally-identifiable-financialinformation-online.html
} 


\section{Chapter 2}

\section{Informed Trading at Capitol Hill:}

\section{Evidence from Congressional Trading}

\section{$2.1 \quad$ Introduction}

Alleged insider trading by members of Congress (politicians) caused mounting public pressure, which was a catalyst for change in the passage of the Stop Trading On Congressional Knowledge (STOCK) Act of 2012. ${ }^{1}$ This act banned trading using congressional knowledge on pending legislation and mandated congressional stock trades to be available online within two months of the transaction date by changing the annual paper-based filing requirement. One year later, Congress, with unanimous approval and in just 24 seconds, amended the STOCK Act by making online disclosure requirements for members of Congress and the Executive Branch optional and by striking down the section of the law that allowed the public to search, sort, and download the data in these electronic reports because of "identity theft and national security concerns". ${ }^{2}$ Such a hasty change raised questions whether Congress used allegations of national security and identity theft concerns to impede the effectiveness

\footnotetext{
${ }^{1}$ For example, see the articles available at http://www.economist.com/node/21541434 and http://www.cbsnews.com/8301-18560_162-57323527/congress-trading-stock-on-inside-information/

${ }^{2}$ http://sunlightfoundation.com/blog/2013/04/18/stock-act-strikeout-visualized/ and http://www.reuters.com/article/2013/04/12/net-us-usa-congress-security-idUSBRE93B0ZJ20130412
} 
of the STOCK Act. ${ }^{3}$ These recent changes suggest that there still could be a wealth of information embedded in recent congressional stock trades despite a new study that finds no evidence of informed trading in Congress (Eggers and Hainmueller, 2013a).

Politicians differ from retail traders and corporate insiders in that they generate or have access to private political information. The use of such information can be quite profitable not only for politicians but also other traders. For example, the Washington Post reports that there was unusual trading activity in the options of Humana, a health insurer, after a staffer on the Senate Finance Committee, talked about the prospects of a critical Medicare bill in a conference call organized by Capitol Street, a consulting firm, on March 18, 2013. On April 2, 2013, the government officially announced a rate increase for Medicare-participating insurers, which generated $500 \%$ or more returns on the options bought right after the conference call. ${ }^{4}$ The Wall Street Journal reveals that there was also a widespread spike in healthcare stocks just before the markets closed on April 1, 2013. This spike was triggered by a tip from a congressional staffer-turned-lobbyist who used to work at the Senate Finance Committee. ${ }^{5}$ One unidentified trader purchased 2,200 call options worth $\$ 368,025$ scoring approximately $\$ 1.6$ million in profits when the official announcement came out the following day. These events even triggered a SEC investigation due to possibility of leaking and trading on nonpublic and material information. ${ }^{6}$ These scandals are examples of how information from a powerful committee like the Senate Finance Committee can move the stock prices.

This paper investigates whether politicians are informed traders by using panel (pooled) regressions and calendar-time portfolios. We document that firm-level trading activity by politicians in the previous three months predicts future firm-level stock returns. The pre-

\footnotetext{
${ }^{3}$ http://www.forbes.com/sites/nathanvardi/2013/04/21/did-obama-and-congress-use-national-securityfears-to-gut-the-stock-act/

${ }^{4}$ http://articles.washingtonpost.com/2013-05-06/business/39066133_1z_investors-conference-call-staffmember

${ }^{5}$ http://online.wsj.com/article/SB10001424127887324345804578427102504475618.html

${ }^{6}$ http://online.wsj.com/article/SB10001424127887324582004578459714133929632.html
} 
dictive ability is stronger for smaller firms and for the pre-recession period. We also find that the portfolios of Republicans earn short-term abnormal returns exceeding $16 \%$ on an annual basis under the one-week holding period whereas there is almost no evidence of informed trading in the portfolio returns of Democrats. The abnormal returns are greater on the portfolios of powerful Republicans compared to non-powerful ones, but there does not appear to be a difference between the portfolio performance of powerful and non-powerful Democrats. These results imply that power is a determinant of abnormal returns only when it interacts with party membership. Sorting powerful Republicans into sophisticated and unsophisticated investor classes reveals that the portfolios of the unsophisticated investors outperform those of the sophisticated ones with abnormal returns exceeding $34 \%$ on annual basis under one-week holding period. Overall, we present evidence that there is nontrivial private political information in congressional stock trades that generates abnormal returns in the short-term, and unsophisticated powerful Republicans are the most informed traders of all.

Our study contributes to the literature the following ways. First, it is unique in documenting that past firm-level trading activity by politicians predicts future firm-level stock returns, and politicians are alike corporate insiders in that they also predict the returns of small companies better. Second, we provide the most consistent evidence in the literature that there is a substantial difference in the portfolio performance of Republicans and Democrats. Third, our paper is the first study investigating the joint effect of power and party membership on congressional stock returns. Fourth, we document that information in congressional stock trades has a very time-sensitive nature. Fifth, we show that there is a negative relationship between investor sophistication and degree of informed trading among politicians. Finally, our results contribute to the market efficiency literature by showing that markets are not strong-form efficient. 
The results of this study complement those in Karadas (2013c) showing that politicians trade on firm-specific information in addition to macroeconomic information. Our paper differs from the first studies on congressional trading (Ziobrowski et al., 2004; Ziobrowski et al., 2011) in that we use a more refined approach into separating informed and uninformed politicians based on the power structure of congressional committees and investor sophistication rather than the seniority of the politicians. Furthermore, our study measures the abnormal returns in a dynamic setup with holding periods ranging from one week to one year. We also employ panel estimation methods to analyze the predictive ability of congressional trading for different sizes of firms. Moreover, using more recent data (2004-2010) helps us examine the information content of congressional trading around the Great Recession. Finally, the recent data presents us with the opportunity to reveal the consequences of the Republican dominance, especially in the US House, following the 1994 US midterm elections.

Our analysis provides insights that are not documented by the recent studies on the performance of common stock investments by politicians (Eggers and Hainmueller, 2013a; 2013b). These studies do not document widespread abnormal returns using data from the 2004-2008 period. Nevertheless, they find 3\% abnormal returns on an annual basis in the local investments of politicians, but these investments do not generate short-term abnormal returns. The magnitude and time dimension of abnormal returns in these recent studies suggest that we are looking at different aspects of congressional trading.

Our study has some limitations. First, we do not test whether politicians trade on information related to specific legislation they work on or companies that their committees regulate. Second, it is possible that politicians use a mosaic of nonpublic information mixed with public information instead of specific tips. The use of such information falls under the mosaic theory, which is often brought up by the defense attorneys at the recent insider 
trading cases such as Raj Rajaratnam and Rajat Gupta. ${ }^{7}$ We do not distinguish between these different uses and acquisitions of information in our paper. Third, we do not measure the impact of the STOCK Act on the trading behavior of politicians due to lack of data.

The rest of the paper proceeds as follows. Section 2 provides a brief literature review on the intersection of politics and finance, and on trading by retail traders and corporate insiders. Section 3 develops the testable hypotheses. Section 4 introduces the transactions and committee assignment data. Section 5 and 6 outline the empirical methods and present the results of the empirical analysis. Section 7 separately examines the portfolio performance of skill-driven and information-driven trades. Section 8 summarizes the result of net worth-based portfolio analysis. Section 9 is on the relationship between power and portfolio performance. Section 10 provides a rigorous analysis of party membership and the extent of informed trading. Section 11 is on the source of private information that members of Congress trade on. Section 12 concludes the paper.

\subsection{Literature Review}

The question whether politicians are trading on private political information in their common stock investments has attracted a great deal of attention in the last two decades. The first comprehensive study answering this question is conducted by Ziobrowski et al.(2004). By constructing transactions-based calendar-time portfolios (i.e., synthetic portfolios), they find that U.S. Senators' common stock portfolios outperform the market over the 1993-1998 period. When they measure the performance of buy-minus-sell portfolios (portfolios that long the buy transactions and short the sell transactions) at the party level, they find very weak evidence of abnormal returns for Democrats and no evidence of abnormal returns for Republicans with the difference being statistically insignificant. In a related study in 2011,

\footnotetext{
${ }^{7}$ http://dealbook.nytimes.com/2010/11/29/just-tidbits-or-material-facts-for-insider-trading/ and http://www.forbes.com/sites/walterpavlo/2012/05/22/rajat-gupta-trial-will-be-governments-test-ofmosaic-theory/
} 
they find abnormal portfolio performance for the U.S. House of Representatives over the 1985-2001 period. However, they document that Democrats perform better than Republicans subject to how the portfolio returns are weighted. In both studies, they use the seniority of politicians as a proxy for power, but document that junior politicians perform better than senior ones in their common stock investments. Their results are not very surprising given that the importance of seniority declined after the 1995 Republican takeover of the U.S. House (Stewart III, 2012).

In our paper, we use a ranking of congressional committees based on their power structure in Congress and thus rely on a more consistent measure of power. We also measure the magnitude of abnormal returns in a dynamic fashion under holding periods ranging from one week to one year while Ziobrowski et al. (2004; 2011) use only one-year holding period. The dynamic holding periods shed light on whether politicians trade on time-sensitive information. Also, the sample period in these previous studies refer to a period when the balance of power started shifting towards Republicans following the 1994 midterm elections. Therefore, this sample period does not give us a clear picture on the relationship between party membership and informed trading. The Republican Party brought in sweeping changes to Congress following their midterm election success and significantly altered the power structure in the House of Representatives (Stewart III, 2012) since then. Republicans controlled the US House from 1995 until today with the exception of the 2007-2010 period. The Republicans were also in control of the Senate in 10 out of 16 years between 1995 and 2010. These long periods of (mostly) uninterrupted majority control suggest that the Republican Party stayed in power long enough to permanently alter the balance of power in Congress. As a result, using recent data after the change in the power dynamics stabilized presents us with the opportunity to examine how the Republican takeover of Congress in the mid-90s had an impact on the portfolio performance of Republicans and Democrats. 
Karadas (2014c) documents a systematic component in congressional trades such that aggregate congressional trading predicts future stock market returns over the 2004-2010 period. This finding implies that congressional stock trades are also driven by economywide information. Eggers and Hainmueller (EH hereafter, 2013a) conduct an examination of congressional stock returns over the 2004-2008 period. They investigate the presence of abnormal return using politicians' portfolio holdings based on various criteria such as politicians' power, net worth, seniority, and party membership, and fail to find any abnormal returns. On the contrary, we document short-term abnormal returns for Republicans and higher short-term abnormal returns for powerful Republicans by using a transacted-based portfolio-based approach.

Our study differs from the EH (2013a) paper in the following ways. First, by only focusing on the stocks that politicians hold, they drop the sell transactions from their analysis. We later document that there is non-negligible private information in the sell transactions of powerful Republicans. Second, when EH (2013a) group transactions and politicians in the powerful and non-powerful samples, they assume that if a politician serves on a powerful committee at some point during the sample period, all of his transactions should be classified in the powerful transactions' sample. We however show that the abnormal returns for the same politicians change considerably between the time that they are powerful and that they are non-powerful. Also, the authors do not look at the joint impact of party membership and power on congressional stock returns. Third, the holdings-based approach does not distinguish between short-term and long-term abnormal returns. As they explain in their subsequent paper (EH, 2013b), the presence of long-term abnormal returns implies that members of Congress trade in a similar fashion to retail traders investing in local stocks: the source of information is more about using their extensive network and general knowledge rather than trading on time-sensitive information. It is critical that we determine whether private political information comes from politicians' in-depth knowledge of companies (long- 
term) or their current activities (short-term).

The fourth difference between our study and EH (2013a) is that they include every congressperson who owned a stock during the 2004-2008 period in their portfolio analysis even though some of them did not place a single trade during the entire sample period. For example, in their full sample, they use portfolio returns from 422 members of Congress, but only 348 of them traded stocks during the 2004-2008 period according to our analysis. It is likely that these buy-and-hold type investors do not trade based on private information, and they are more likely to have average market returns. Fifth, instead of relying on seniority, we use a measure of investor sophistication to separate skill-driven trades from informationdriven trades. Fifth, we construct portfolios based on the ratio of transaction values to politicians' net worth to screen for high information-content trades instead of focusing only on net worth. Finally, EH (2013a) use estimates for transaction and asset values for the majority of the sample, which may confound the portfolio performance of politicians. We provide a more in-depth analysis of this estimation issue in the empirical analysis section.

Eggers and Hainmueller (2013b) sort politicians' transactions into connected and unconnected portfolios based on firms' proximity to a politician's district, campaign contributions, and lobbying activities targeting a politician's committee. They find that politicians have strong preferences to invest in companies headquartered in their districts, and these investments generate $3 \%$ annualized abnormal returns. Nevertheless, they don't find any short-term abnormal returns in these connected portfolios (location, lobbying and campaign contribution) based on the transactions-based calendar-time portfolios (i.e., synthetic portfolios), and they argue that politicians invest in local stocks based on their general knowledge of the local management, but not on time-sensitive information. They additionally show that this local premium does not depend on whether traders are powerful politicians or not. 
Our study complements the research on how politics affects the value and decisions of firms. By focusing on the most powerful 20 committees in Congress (10 from each chamber), Cohen et al . (2011) find that when a politician becomes the chairman of a powerful committee, the federal spending in his or her state increases, which in return crowds out corporate investment and employment. Tahoun and Van Lent (2010) document that politicians are more likely to bail out a firm if they hold its stock. Furthermore, the chance of a bail-out is higher for firms with investors from powerful committees. Cooper et al. (2010) present evidence that there is a positive relationship between the number of candidates a firm supports during an election and its subsequent abnormal returns. Kim et al. (2012) construct a political alignment index (PAI) between a state's politicians and the President, and show that there is a positive relationship between PAI and stock returns. They argue that the higher alignment is associated with higher chances of legislative change, and thus higher political risk. Belo et al. (2013) find that firms with higher levels of exposure to government spending perform better (worse) than those with lower levels of exposure when the president is a Democrat (Republican).

Our paper is closely related to the stream of studies on the investment performance of retail traders and corporate insiders. Odean (1999) investigates whether retail investors are overconfident in their trading decisions. He constructs calendar-time portfolios for buy and sell transactions and finds that the intercept (alpha) on the buy-minus-sell portfolio is significantly negative. His analysis implies that investors misinterpret information about stocks and that they have poor skills in projecting which stocks will rise and which stocks will fall in value. Seasholes and Zhu (2010) examine the investment skills of individual traders by looking at their local (stocks) holdings and transactions. By constructing holdings-based and transactions-based calendar-time portfolios, they document that individual traders do not earn abnormal returns on their holdings, and their transactions do not contain value-relevant information. 
This paper is also linked to the studies on corporate insider trading and market efficiency. Lakonishok and Lee (2001) present evidence that corporate insiders are able to predict market and cross-sectional stock returns. They show that the source of predictive ability comes from insiders in smaller firms and buy transactions. Jeng et al. (2003) document that buy transactions by corporate insiders outperform the market exceeding $6 \%$ a year while sell transactions do not have any abnormal performance. Cohen et al. (2012) filter out routine trades by corporate insiders and document abnormal returns around $10 \%$ a year for the rest of the transactions.

\subsection{Hypotheses}

\subsubsection{Predictive Ability}

We are primarily interested in uncovering the information content of congressional stock trades. If politicians are informed traders using value-relevant information, we should see a relationship between the direction of their past trades and future stock prices. Buy (sell) transactions should be followed with higher (lower) stock prices. Based on this expectation, we formulate our first hypothesis the following way:

- $H_{1}$ : There is a relationship between firm-level trading activity by politicians and stock returns such that past firm-level trading activity predicts future firm-level stock returns.

The insider trading literature shows that corporate insiders from smaller companies are better at predicting their firms' stock returns than those from larger companies (Lakonishok and Lee, 2001). The main argument in these studies is that there is more information asymmetry between public and management in smaller companies, and thus corporate insiders have an edge over outsiders. We argue that politicians also have a better chance of predicting 
the returns of smaller companies due to higher levels of information asymmetry about these companies. As a result, we formulate the second hypothesis as:

- $\mathrm{H}_{2}$ : The predictive ability of firm-level trading activity is stronger for smaller companies.

\subsubsection{Abnormal Returns}

Finding a strong positive relationship between past trading activity and future stock returns is a critical step towards establishing that politicians are informed traders, and there is value-relevant information embedded in congressional stock trades. If this information is valuable enough, then we should see positive abnormal returns on a portfolio that buys what politicians buy and sells what they sell (i.e., buy-minus-sell, hedged, long/short portfolio). Such a relationship does not necessarily establish that politicians reap all of these abnormal returns since we use hypothetical holding periods and take into consideration the losses avoided by selling at the right time. Nevertheless, this methodology presents evidence whether the value in the congressional stock trades is material enough to generate abnormal returns. As a result, our third hypothesis is:

- $H_{3}$ : Politicians trade on value-relevant information such that their trades generate abnormal returns.

We anticipate that the members of the Republican Party trade on more value-relevant information than those of the Democratic Party for the following reasons. The Republican takeover of Congress ensuring the 1994 elections (so-called Republican Revolution) changed the power balance in Congress in favor of the Republican Party. Republicans controlled the US House between 1995 and 2006, and the US Senate between 1995 and 2006 with the exception of the 2000-2001 period, which gave them the opportunity to implement the changes they pioneered. ${ }^{8}$ Stewart III (2012) documents that the transition in the power from

\footnotetext{
${ }^{8} \mathrm{http} / / /$ cstl-cla.semo.edu/renka/ui320-75/presandcongress.asp
} 
Democrats to Republicans had an especially significant effect in the House of Representatives, which represents approximately $75 \%$ of all transactions and traders.

The Republican Revolution was followed by the K Street Project, which was aimed at aligning the influence of lobbyists with the Republican Party by encouraging lobbying firms to hire Republicans in exchange for preferential access to powerful politicians. ${ }^{9}$ Republicans promoted this project to reduce the Democratic influence in the lobbying industry due to the long-held Democratic majority in Congress. ${ }^{10}$ According to the government watchdog POLITICO, Republicans still dominate the K Street despite losing control of the House for the 2007-2010 period and being the minority party in the Senate since 2007. ${ }^{11}$ The K Street Project cemented the ties between the Republican Party and the business community in addition to leading to increased campaign contributions to Republican candidates from lobbyists. ${ }^{12}$ We argue that the change in the power structure in Congress and the dominance in the lobbying industry, which is sometimes deemed as the fourth branch of the government ${ }^{13}$ enhanced the access to private political information by the members of the Republican Party. As a result, we expect that the members of the Republican Party are more informed than those of the Democratic Party, and set our fourth hypothesis as follows:

- $H_{4}$ : Abnormal returns on the portfolios of Republicans exceed those on the portfolios of Democrats.

Politicians widely differ with respect to how much power they have. We argue that powerful politicians in general possess more value-relevant information than other politicians because they are in positions to acquire more information and to be more influential in decisions that may affect stock prices. As a result, we anticipate that:

\footnotetext{
${ }^{9}$ http://www.npr.org/templates/story/story.php?storyId=5148982

${ }^{10}$ http://www.washingtonpost.com/blogs/fact-checker/post/rick-santorum-and-the-k-street-project-factchecker-biography/2012/01/05/gIQAbqwgjP_blog.html

${ }^{11}$ http://www.politico.com/story/2013/03/lobbying-republicans-keep-grip-on-k-street-89007.html

${ }^{12}$ http://www.huffingtonpost.com/2012/01/05/rick-santorum-lobbyists-k-street-project_n_1186606.html

${ }^{13}$ http://abcnews.go.com/US/story?id $\overline{1} 517964$
} 
- $H_{5}$ : Abnormal returns on the portfolios of powerful politicians are higher than those on the portfolios of non-powerful politicians.

\subsection{Data}

\subsubsection{Transactions Data}

We obtain raw daily transactions data for the 2004-2010 period from the Center for Responsive Politics (www.opensecrets.org). This study covers the period preceding the STOCK Act of 2012. Prior to the STOCK Act, politicians were required to file annual financial disclosure reports (FDR) by May 15th of every calendar year for their own and their family members' transactions exceeding $\$ 1,000$ that take place during the previous calendar year.

The raw data do not come with security identifiers. As a result, we match the raw dataset with the Center for Research in Security Prices (CRSP) data by using company names. We ensure that each asset has a permanent identifier (PERMNO) in the matched sample. Following Ziobrowski et al.(2004), we only keep transactions on U.S. common stocks (CRSP share code 10 or 11) trading on NYSE, AMEX and NASDAQ. We also eliminate transactions if there is no transaction date, no transaction amount, or the transaction amount is less than $\$ 100$.

We refine our sample further by following Ziobrowski et al. (2011) and eliminate transactions if there are not any stock returns within $-/+15$ days of the transaction date to possibly drop the transactions involving initial public offerings (IPOs). The FDRs do not always indicate the precise dollar amount of transactions. Many transaction amounts are

provided within intervals such as between $\$ 1,001-\$ 15,000$. As in Ziobrowski et al. (2004), we use the midpoint of such intervals as the dollar amount of transactions. Our final sample has 61,998 transactions and 2671 unique stocks. $49.76 \%, 46.72 \%$, and $3.52 \%$ of the stocks 
are listed on NYSE, NASDAQ, and AMEX, respectively. Out of 61,998 transactions, 30,785

and 31,213 of them are buy and sell transactions, respectively, and there are a total of 403 politicians in the sample.

\subsubsection{Committee Data}

We obtain the committee assignment data from Stewart III and Woon (2011). ${ }^{14}$ We merge the transaction data with the committee assignments by precisely matching the transaction dates and the period of committee membership. Let's suppose that politician A served on the Senate Appropriations Committee in 2007 and 2008, but he had common stock transactions during, before, and after his service period. We ensure that only the transactions that politician A carried out in 2007 and 2008 are associated with the Senate Appropriations Committee.

Similar to Cohen et al. (2011), we focus on the most powerful 20 committees (top 20), 10 from each chamber. We follow a more recent ranking produced by Charles Stewart III (Stewart III, 2012) while Cohen et al. (2011) employ an earlier version of the committee rankings that have less overlap with our sample period (Edwards and Stewart III, 2006). Stewart III (2012) uses an econometric technique, Grosewart method, based on the revealed preferences of politicians. For example, if a politician gives up his seat on the House Foreign Affairs committee to serve on the House Rules Committee, the value from serving on Rules exceeds the value from serving on Foreign Affairs. Here value refers to the set of monetary and non-monetary benefits politicians can extract from serving on a committee. For example, landing a private sector job after leaving Congress or accomplishing key legislative changes could be the benefits a politician attaches to serving on a given committee. The Grosewart method yields cardinal values for each congressional committee that are later used to rank

\footnotetext{
${ }^{14}$ We are thankful to Charles Stewart for making committee assignment data available to public at http://web.mit.edu/17.251/www/data_page.html. See www.opensecrets.org for the descriptions of congressional committees.
} 
congressional committees.

The powerful committees in order of importance are Ways \& Means, Energy \& Commerce, Appropriations, Rules, Foreign Affairs, Financial Services, Armed Services, Judiciary, House Administration, and Budget in the House. ${ }^{15}$ In the Senate, these committees in order of importance are Finance, Appropriations, Rules \& Administration, Armed Services, Commerce, Governmental Affairs, Health, Judiciary, Budget, and Veteran Affairs. ${ }^{16}$

\subsection{Firm-Level Analysis: Panel Data Approach}

We employ two different approaches to measure the value-relevance of congressional stock trades. First, we investigate whether past firm-level trading activity by politicians predicts future firm-level stock returns in a panel data framework. This approach helps us determine whether there is nontrivial value-relevant information on the common stock investments of politicians. Second, we construct transactions-based calendar-time portfolios and measure the abnormal returns at different holding periods ranging from 5 to 252 trading days (i.e., one week to one year).

Politicians traded 2,671 different common stocks during our sample period. It is critical to determine whether they have private political information in just a handful of companies or in a large majority of them. If politicians have information about a stock, the way that they traded this particular stock should correlate with its future returns. For example, if

\footnotetext{
${ }^{15}$ We do not have any transactions associated with Ethics Committee, which ranks \#9 in the House. We instead use the next committee, House Administration, for which we have available data.

${ }^{16}$ We also use the power committees in EH (2013a). EH (2013a) focuses on the most powerful 7 committees (top 7), 4 from the House and 3 from the Senate based on Stewart III (2012). Nevertheless, they elevate the ranking of the Senate Commerce Committee possibly because of the extremely rapid rise in its power in the last two decades and the declining popularity of some congressional committees such as Armed Services (Stewart III, 2012). Overall, EH (2013a) classify Rules, Appropriations, Ways \& Means, and Commerce in the House; Appropriations, Finance, and Commerce in the Senate as the powerful committees. Using top 7 instead of top 20 committees improves the short-term abnormal returns. The results are available from the author upon request.
} 
politicians place 100 buys and 10 sells in a stock in a given month, we should anticipate appreciation of the stock price in the subsequent month if their trades contain value-relevant information. The main objective of our paper is to find out whether members of Congress are informed traders in general. In other words, we are interested in documenting whether their informational advantage extends beyond a handful of companies. If this is the case, we should see a statistically significant relationship between politicians' past trading activity and future stock returns using a panel framework.

The firm-level trading analysis presents us the opportunity to investigate the timesensitivity of congressional stock trades. The number of months over which we measure the trading activity tells us about the time dimension over which information is value-relevant. Thanks to a large number of observations in the panel regressions, the firm-level analysis is also helpful for examining the presence of informed trading for short time intervals such as the post-recession period.

\subsubsection{Setup}

We measure firm-level trading activity based on the net number of transactions from the previous three months:

$$
\text { net3trade }_{i, t}=\frac{\sum_{j=1}^{3} \text { NBuys }_{i, t-j}-\sum_{j=1}^{3} N \text { Sell }_{i, t-j}}{\sum_{j=1}^{3} N \text { Buys }_{i, t-j}+\sum_{j=1}^{3} N \text { Sell }_{i, t-j}}
$$

where $N$ Buys $_{i}$ and $N$ Sell $_{i}$ are the number of buy and sell transactions that all politicians make in firm $_{i}$ a given month. Lakonishok and Lee (2001) also employ a similar approach to measure insider trading activity by including the transactions stretching back to more than one month in order to have more firm-years in the sample and to capture the broader patterns in the data. 
As in Cohen et al. (2012), we estimate a panel regression (standard errors are clustered at the firm level) with and without month fixed effects and employ past one month stock returns, past 12 month stock returns, market capitalization, and book-to-market ratio as the additional control variables. As a result, we estimate the following equation:

$$
\operatorname{rret}_{i, t}=\alpha_{i}+\beta_{1} \text { net } 3 \text { trade }_{i, t}+\beta_{2} r_{i, t-1}+\beta_{3} r_{i,(t-2, t-12)}+\beta_{4} \log \left(\text { size }_{i, t}+\beta_{5} \log (b m)_{i, t}+\varepsilon_{i, t}\right.
$$

where the dependent variable, rret $_{i, t}$, is the raw stock return of firm $i$ in percentages in month $t . \quad r_{i, t-1}$ is the past month raw return of firm $i$, and $r_{i,(t-2, t-12)}$ is the cumulative continuously compounded returns of firm $i$ from month $t-12$ to $t-2$. $\log ($ size $)$ is the $\log$ of market capitalization (in millions) measured in June of each calendar year $T$, and $\log (b m)$ is the log of book-to-market ratio with book equity measured in December of calendar year $T-1$ for all fiscal years ending in calendar year $T-1$. Both $\log (\operatorname{size})$ and $\log (\operatorname{bm})$ are attached to stock returns from July of year $T$ to June of year $T+1$ (Fama and French, 1992; Fama and French, 2008). We provide the summary statistics and correlations (Pearson's) of the regression variables in Table 2.1. The average returns are positive during the sample period. There is a statistically significant correlation between all variables except for rret and $\log ($ size $)$. However, the magnitude of the statistically significant correlation coefficients does not appear to be large enough to be the source of the multicollinearity problem.

\section{[Table 2.1 About Here]}

Eq. (1) generates many missing values since politicians trade some stocks very infrequently. We adopt two strategies to handle these missing observations. First, it could be that politicians did not have any information during these periods and hence they did not trade. In this case, we simply ignore those missing observations as in Eq. (2). It is also possible that politicians had some neutral information (neither bad nor good) about those 
firm-months and simply avoided trading. If this scenario is the case, dropping the missing observations may give us an incomplete picture about the predictive ability of congressional trading. In order to account for this possibility, we also estimate Eq. (2) with full3trade instead of net3trade, which replaces the missing index values with zeros.

\subsubsection{Main Results}

Columns 1-2 in Panels A and B of Table 2.2 present the main results of the panel regressions. net3trade predicts the future stock returns even after controlling for month fixed-effects implying that there is value-relevant information embedded in congressional stock trades. Also, full3trade has a predictive ability, which suggests that the periods of no-trade still contains valuable information with politicians avoiding trading stocks as a result of neutral information. Overall, these results support Hypothesis 1.

\section{[Table 2.2 About Here]}

\subsubsection{Longer Time Horizon}

We do a robustness check by constructing another trading index, net6trade, based on the previous six months of congressional trading activity:

$$
\text { net6trade }_{i, t}=\frac{\sum_{j=1}^{6} \text { NBuys }_{i, t-j}-\sum_{j=1}^{6} \text { NSells }_{i, t-j}}{\sum_{j=1}^{6} \text { NBuys }_{i, t-j}+\sum_{j=1}^{6} \text { Sells }_{i, t-j}}
$$

where $N B u y s_{i}$ and $N S_{e l l} s_{i}$ are the number of buy and sell transactions that all politicians make in firm $_{i}$ a given month.

Columns 1-2 of Panel C of Table 2.2 show that the information of content of firm-level trading activity degenerates once we extend it to include the transactions in the previous six months. These results suggest that politicians tend to trade on time-sensitive information 
whose content loses its value-relevance as more time passes subsequent to the transaction date.

\subsubsection{Is Information Related to Firm Size?}

Lakonishok and Lee (2001) document that corporate insiders in small firms are better at predicting their companies' stock returns than those in large firms. Motivated by this finding, we carry out firm-level estimations for both small and big market capitalization firms using net3trade, full3trade, and net6trade as the predictors. We use the median market value of NYSE listed firms to sort the stocks into small and big groups. It is essential to bear in mind that a politician may have investments in both small and big companies.

Columns 3-6 of Table 2.2 show that the transactions by politicians predict the returns of small companies even after controlling for month fixed effects, which is in agreement with Hypothesis 2. The predictability of the returns of big companies disappears after controlling for month fixed effects. On the other hand, the predictive ability for small firms disappears when we use net6trade as the predictor. These results suggest that politicians, like corporate insiders, predict the returns of small market capitalization companies better than those of big market capitalization companies, but this prediction is based on time-sensitive information.

\subsubsection{Subperiod Analysis around the Great Recession}

We repeat our analysis for three different sub-periods: pre-recession, recession, and postrecession based on the recession indicators from St Louis Federal Reserve. ${ }^{17}$ Such an analysis sheds light on the issue whether politicians systematically used political private information in their common stock trades, especially during the financial crisis as speculated in the media. ${ }^{18}$ The results in Table 2.3 indicate that the most of the informed trading took place

\footnotetext{
${ }^{17}$ These indicators are available as a dummy variable at http://research.stlouisfed.org/fred2/series/USREC

${ }^{18} \mathrm{http}$ ///articles.washingtonpost.com/2012-06-24/politics/35459172_1_portfolios-boehner-financial-crisis
} 
prior to the recession, and the information in congressional stock trades ceased to be valuerelevant in the post-recession period.

[Table 2.3 About Here]

\subsubsection{Trades in Illiquid Stocks}

We have assumed that each trade by politicians reveals private political information. There is however the possibility that politicians can buy or sell a stock in sequence of orders without revealing any new information if this stock is relatively illiquid. In other words, politicians may be concerned about price fluctuations when they trade illiquid stocks. If politicians act in this way, eliminating multiple transactions (combining them into a single trade) in relatively illiquid stocks should increase the predictive ability of net3trade since we will be discarding uninformative trades.

By following Amihud (2002), we construct an annual firm-level illiquidity index. We first

obtain all available stock returns from WRDS over the 2003-2009 period. Next, we only keep observations with valid returns and volume data. We also require being a US domestic stock and being listed on major US stock exchanges to stay in the sample. Having filtered our data, we calculate our illiquidity measure following Eq. (4):

$$
\text { Illiquidity }_{t}^{i}=\frac{1}{N A v a_{t, i}} \sum_{k=1}^{N A v a_{t, i}} \frac{\mid \text { Return }_{t, k}^{i} \mid}{\text { Dvol }_{t, k}^{i}}
$$

where Illiquidity $t_{t}^{i}$ is the annual illiquidity index for firm (stock) $i$ in year $t, N A v a_{t, i}$ is the number of days over which we have valid data for firm $i$ in year $t, \operatorname{Return}_{t, k}^{i}$ is stock $i$ 's return in day $k$ and year $t$, and $D v o l_{t, k}^{i}$ is stock $i$ 's dollar trading volume in millions in day $k$ and year $t$. A higher index value implies wider fluctuations in stock price for a given change in daily trading volume, and thus is an indicator of illiquidity. 


\section{[Table 2.4 About Here]}

Based on our annual illiquidity measure, we sort stocks into quintiles for each year from 2003 to 2009 such that the most liquid stocks go into the lowest quintile. We merge the illiquidity quintile in year $t$ with the congressional transactions data in year $t+1$ so that the trades by the politicians do not confound our illiquidity measure. $86.10 \%$ of the transactions in our dataset fall under the lowest illiquidity quintile whereas only $0.20 \%$ of them fall under the highest illiquidity quintile. If a stock is in Quintile 1 (lowest illiquidity), we do not eliminate any transactions. For the stocks in the other four quintiles, if there are multiple buy (sell) trades in a given month, we combine them into a single buy (sell) trade. We present the illiquidity-filtered results in Table 2.4. The predictive ability of congressional trading improves at the margins after filtering transactions based on illiquidity.

\subsubsection{Limitations}

The firm-level trading index, net3trade, may suffer from insufficient cross-sectional variation. Out of 49,081 valid observations, $10.35 \%, 31.48 \%$, and $32.92 \%$ of them are 0,1 , and -1 , respectively. As a result, we use the calendar-time portfolio approach to complement the results of the firm-level analysis. The portfolio analysis also enables us to measure the trading performance of the politicians in terms of abnormal returns.

\subsection{Calendar-Time Portfolio Analysis}

\subsubsection{Empirical Motivation}

When there is cross-sectional dependence in the abnormal returns, the test statistic based on the cumulative abnormal returns is inflated, and it over-rejects the null of no abnormal returns (Lyon et al., 1999). Therefore, Fama (1998) and Mitchell and Stafford (2000) strongly favor the use of the calendar-time portfolio approach that solves the problem of 
cross-sectional dependence in the data. Our data has overlapping return windows and event clustering that plague the event study-based inferences. Furthermore, politicians sometimes invest in the same stocks over similar time periods generating correlations between their portfolios. The construction of calendar-time portfolios yields a single time series of returns, which eliminates the problem of cross-sectional dependence (Seasholes and Zhu, 2010).

The calendar-time portfolio approach has some drawbacks. Mitchell and Stafford (2010) list some of the issues that may plague the calendar-time portfolio approach. First, standard asset pricing regressions assume constant coefficients on asset pricing factors, but the number and type of firms in the monthly calendar-time portfolios change, which may cause estimates to be biased. Second, the changing portfolio composition could also be at odds with the homoskedasticity assumption, and this issue is also raised by Fama (1998). Third, Loughran and Ritter (2000) point out that this approach treats each month identically with equal weights and ignore the possibility of some months having different abnormal return patterns than others. Finally, Fama (1998) argues that the bad model problem (CAPM, Three-Factor Model, etc.) can generate anomalies that do not exist in reality.

In dealing with the heteroskedasticity problem, we follow Seasholes and Zhu (2010) and estimate the asset pricing equations with Newey-West heteroskedasticity and autocorrelation robust standard errors. We attempt to alleviate the bad model problem by estimating four different models (CAPM, three-factor, four-factor, and five-factor models). The firm-level analysis in Section 1.5.5 shows that most of the value-relevant information comes from the transactions from the pre-recession period, and there is almost no value-relevant information in the post-recession period. As a result, assigning equal weights to each month would make it easier to fail to reject the null of no abnormal returns. We argue that the remaining problem, the constant coefficient assumption, is less of a concern than the problems associated with the event analysis approach given that we have a short-time series data. 


\subsubsection{Two Choices for Calendar-Time Portfolios}

There are two different calendar-time portfolios: holdings-based and transactions-based calendar-time portfolios, and this study is based on the latter. The former is simply the actual portfolios held by politicians. On the other hand, the transactions-based approach creates synthetic portfolios based on what politicians buy and what they sell under different holding periods. The main focus in these synthetic portfolios is the long/short (buy-minussell) portfolio that longs the buy transactions and shorts the sell transactions. We prefer the transactions-based approach to the holdings-based approach for the following reasons:

- Time-sensitivity of information (dynamic view): The transactions-based approach allows us to measure abnormal returns under different holding periods (1 week, 1 month, etc.) and to investigate whether there is any time-sensitive information in stock trades. If politicians trade on time-sensitive information, then we should expect abnormal returns on the long/short portfolio under the shorter holding time periods. On the other hand, if politicians invest in stocks based on long-term information, then we should expect abnormal returns on the same portfolio under the longer holding time periods. It is not possible to make such a distinction in the holdings-based approach.

It is critical to establish the dynamic structure of the private information used in congressional stock trades. The presence of abnormal returns over the long-term holding periods (one year or more) implies that politicians possess the skills to extract information that has value-relevance beyond short-term trading windows. Therefore, their trading decisions are mostly independent of the current bills or projects that they work on. Similar to retail traders who collect and process local information at an advantage (Ivkovic and Weisbenner, 2005), they are uniquely positioned to exploit congressional knowledge. On the other hand, the presence of short-term abnormal returns suggests that politicians trade on information that is related to their current activities 
in Congress since such information is more likely to have a time-sensitive nature. In this regard, the use of time-sensitive information raises more red flags than the use of long-term information.

- Sub-portfolios: The transactions-based analysis enables us to separate the transactions in the same stock by the same politician even on the same trading day into different portfolios based on an appropriate criterion. For example, in our study, we place the transactions by the unsophisticated powerful Republicans into three different portfolios based on the ratio of the transaction values to their net worth. EH (2013a; 2013b) use politicians' stock holdings at the end of a given calendar year, and work their way backward to calculate daily portfolio returns based on the transactions that politicians make during that calendar year. For example, a politician reports owning $\$ 20,000$ worth of GE shares at the end of 2010. He also reports two buy transactions on May 1st, 2010. EH (2013a; 2013b) update the daily value of GE holdings from December 31st to May 1st. Next, they subtract the value of these two buy transactions and update the daily portfolio value for the period between January 1st and April 30th. If one buy transaction represents $1 \%$ of the politician's net worth while the other one represents $0.001 \%$, their methodology fails to present the information content of each trade separately due to aggregating them under one single portfolio.

- Insufficient data: EH (2013a; 2013b) construct politicians' daily portfolio returns based on their holdings at the end of the year and transactions during the year as we exemplified in the previous section. Politicians do not always report the exact transaction amounts and asset values. EH (2013a; 2013b) report that they have exact amounts for $25 \%$ of the transactions and $8 \%$ of the end-of-year holdings. For the same sample period, we find that only 45 out of 348 politicians report exact transaction amounts. When the exact values are not stated, politicians report their transactions and asset 
holdings with large intervals such as between $\$ 250,000$ and $\$ 500,000$. For politicians who reported exact transaction and asset amounts, EH (2013a; 2013b) impute the transaction and asset values for the rest of their transactions and assets based on the exact amounts reported by fitting a distribution. Next, they assume that these imputed values should be the same for the rest of the politicians (the ones who did not report the exact transaction and asset amounts) as long as we look at the same intervals. Let's assume that EH (2013a) come up with $\$ 345,000$ imputed value for the $\$ 250,000-\$ 500,000$ interval for the politicians who reported some exact transaction amounts. They use this imputed value for every transaction between this interval for the politicians who did not report any transaction values. Even though their methodology is empirically appealing, it is not clear how much they improve upon simply taking the midpoint of intervals as in Ziobrowski et al. (2004; 2011). In both methods, the transactions by the politicians who do not report exact amounts are assigned a fixed number depending on the interval that they report.

Given that we do not know the exact transaction and asset amounts for most of the politicians and transactions, we argue that daily portfolio values in EH (2013a; 2013b) do not reflect the actual holding returns contrary to what they claim. In the transactions-based analysis, we only rely on the midpoint method to determine the transaction amounts when an interval is reported. Even though we use an estimate too, we do not use another estimate such as end-of-year values to determine the performance of this transaction. Suppose that politician A reported buying shares of ABC company for the first time on February 15, 2008 and provided a $\$ 50,000-\$ 100,000$ interval for the transaction amount. He also reported that the value of his ABC holdings was between $\$ 50,000-\$ 100,000$ at the end of 2008. EH (2013a; 2013b) would first estimate the value of ABC stock at the end of 2008, then determine the value of this holding from December 31, 2008 to February 15, 2008 using daily returns, subtract 
the estimated transaction amount on February 14, 2008, and continue computing the portfolio value until January 1, 2008. As a result, the difference between the portfolio values in January 1 and December 31 becomes very sensitive to the estimated values. In our transactions-based analysis, we simply track the subsequent performance of this transaction from the day it was executed, which depends on its future performance, not some estimated future value. The holdings-based approach would be appealing to us if there was data on the number of shares that members of Congress traded and held at some point in time. This way we could approximately pinpoint the value of their transactions and assets. Nevertheless, the number of shares is not available for transactions and asset holdings.

- Losses avoided: We are interested in determining whether politicians are informed traders. Informed trading is not only about buying but also about selling at the right time. By constructing long/short portfolios, the transactions-based approach takes both buy and sell transactions into consideration. Nevertheless, the holdingsbased approach only focuses on the existing stocks in a portfolio and discards useful information from sell transactions. For example, a politician owning a single stock with an average performance learns that the company will face lawsuits from the government in the coming weeks and immediately sells all of his holdings. The actual holdings-based analysis will show that the politician did not beat the market because the stock had an average performance during the actual holding period. However, the transactionsbased analysis will help us answer whether there were any losses that the politician managed to avoid shortly after the transaction date. Such a finding is critical for an SEC investigation because the SEC is concerned about not only illegal profits acquired but also losses avoided based on non-public material information. ${ }^{19}$

\footnotetext{
${ }^{19}$ For example, on March 29, 2013 the SEC brought charges against Michael Steinberg at Sigma Capital who traded stocks of Dell and Nvidia Corp in advance knowledge of their quarterly earnings with his inside trades generating substantial profits and avoiding large losses for their firm (see http://www.sec.gov/news/press/2013/2013-49.htm) Under the Insider Trading Sanctions Act (ITSA) of 1984, the SEC can seek civil penalties up to three times the profit acquired or loss avoided in an insider
} 
- Delays in reversing a position: It is possible that a politician times his buy transaction well, but may delay reversing his buy position to a sell for a variety of reasons (e.g., avoid suspicion). In such cases, information-based trading will be watered down by regular trading. Suppose that a politician places a trade that has information-benefit for 5 days. If the politician sells this stock 5 days after he bought it, the transactionsbased calendar-time portfolio under the 5-day holding period and the holdings-based calendar-time portfolio can both reveal these abnormal returns. However, if the politician sold this stock 10 days later, the 5-days of non-abnormal returns can cloud the 5-day of abnormal returns with the entire analysis yielding statistically insignificant abnormal returns under the holdings-based approach. The politician was an informed trader in this example, but he could not profit on his information. Nevertheless, the SEC still files criminal charges if a trader uses non-public material information even if he or she acquires no profits or avoids no losses. For example, in SEC vs. Rosenthal, the insiders got charged with criminal penalties, not civil penalties, for trading ahead of two expected mergers that never took place. ${ }^{20}$

\subsubsection{Setup}

Ziobrowski et al. (2004; 2011) use calendar-time portfolio approach in capturing the longrun abnormal returns following Fama's (1998) recommendation. They assume a fixed oneyear holding period and calculate portfolio returns for each calendar day by including all transactions that take place within the prior year. We follow their approach, but construct the portfolios assuming 1/4-,1-, 2-, 3-, 6-, and 12-month holding periods to capture the timesensitivity of information embedded in the transactions. We use the following formula to derive daily portfolio returns:

trading case in addition to seeking criminal penalties.

${ }^{20}$ http://www.law.du.edu/index.php/corporate-governance/sec-and-governance/sec-v.-rosenthal 


$$
R_{\text {port }, t}=\frac{\sum_{j=1}^{J} \operatorname{comp}_{j t} R_{j t}}{\sum_{j=1}^{J} \operatorname{comp}_{j t}}
$$

where $R_{\text {port }, t}$ represents the return on the calendar-time portfolio on trading day $t, \operatorname{comp}_{j t}$ the compound value of transaction $j$ from transaction date until trading day $t-1$. The denominator in Eq. (5) is the sum of the compounded value of each transaction at the beginning of trading day $t$. The numerator is the sum of the dollar returns on each transaction based on the compound value of the transaction at the beginning of trading day $t$. Suppose that the entire portfolio is composed of two transactions involving stock A $(\$ 1,000$ purchase) and stock B (\$5,000 purchase). On day 0 (transaction date), stock A appreciated 10\%, but stock B lost 5\%. On day 1, stock A and stock B went up by $20 \%$ and $10 \%$, respectively. The denominator for day 1 portfolio return is $\$ 1,000 x 1.10=\$ 1,100$ plus $\$ 5,000 x(0.95)=\$ 4,750$, which is $\$ 5,850$. In other words, we start day 1 with $\$ 5,850$ wealth. The numerator for day 1 return is $\$ 1,100 x 0.20=\$ 220$ plus $\$ 4,750 x 0.10=\$ 475$, which is $\$ 695$. In other words, on day 1, we earned $\$ 695$ on an initial investment of $\$ 5,850$ : $\frac{\$ 695}{\$ 5,850}=11.88 \%$ return.

The setup above generates daily returns, and we compound these daily portfolio returns to generate monthly returns as in Ziobrowski et al. (2004; 2011). We first calculate portfolio returns on buy and sell transactions, and then calculate the long/short portfolio returns as the difference between the buy and sell portfolio returns. Our interest primarily lies in the alphas (abnormal returns) on the long/short portfolios (Odean, 1999). Ziobrowski et al. (2004; 2011) compute both equal-weighted portfolio returns assuming $\$ 1$ initial value for each transaction and trade-weighted or value-weighted portfolio returns using original transaction amounts. They also average returns across politicians on each calendar day as a robustness check. We follow their approach, but weight politician (or member)-level returns both equally and by their portfolio size (the sum of the compounded value of all positions) on a given trading day. In other words, we adopt a two-stage weighting scheme. In the first stage, we weight each transaction either equally or by its original transaction amount. In 
the second stage, we weight politician-level returns either equally or by portfolio size. As a result, we use four different weighting schemes to calculate the returns. Figure 1 presents an overview of these weighting schemes.

\section{[Figure 1 About Here]}

The original transaction data cover the 2004-2010 period, but we have the monthly returns up to December of 2011 because the calendar-time portfolio approach allows us to keep any transaction in the sample as long as it takes place within the holding period. For

example, Senator A buys a stock of Company XYZ on March 9, 2010. If we want to calculate the portfolio returns on January 9, 2011 based on the one-year holding period, this stock will be part of the portfolio on this day because there are fewer than 252 trading days between the transaction date and January 9, 2011.

\subsubsection{Measuring Abnormal Returns}

We measure the abnormal returns using the Capital Asset Pricing Model (CAPM), FamaFrench Three-Factor Model, Carhart Four-Factor Model, and Five-Factor Model. We estimate the following time series models using monthly data:

$$
r_{p, t}=\alpha_{i}+\beta_{p}\left(r_{m, t}-r_{f, t}\right)+\varepsilon_{p, t}
$$

where $r_{p, t}$ is the return on the long/short portfolio (buy-minus-sell), $r_{m, t}$ is the CRSP valueweighted index return, and $r_{f, t}$ is the interest rate on the one month treasury bill, which represents the risk-free rate. Next, we add SMB and HML (three-factor model), UMD (four-factor model), and finally LIQUID (five-factor model) to this CAPM equation. SMB, small-minus-big, is the Fama-French size factor constructed by longing a portfolio of small firms and shorting a portfolio of big firms. $H M L$, high-minus-low, is the Fama-French value 
factor constructed by longing a portfolio of high value firms and shorting a portfolio of low value firms (Fama and French, 1993). UMD, up-minus-down, is the momentum factor constructed by subtracting the returns of a portfolio of losing stocks from the returns of a portfolio of winning stocks, and LIQUID is the Pastor and Stambaugh (2003) liquidity factor that is equal to the return difference between the most and least liquid beta portfolios. We collect all of these series from Wharton Research Data Services (WRDS).

The crux of our empirical strategy is to investigate whether $\alpha$ is statistically significant. The null hypothesis is that $\alpha$ is not statistically different from zero, which implies an average investment performance and lack of value-relevant information. The alternative hypothesis is that $\alpha$ is statistically significantly different from zero, which implies either below or abovemarket performance.

\subsubsection{Main Results}

We present the main results of the calendar-time portfolio analysis in Table 2.5. There are abnormal returns on the common stock transactions of politicians. The abnormal returns are the highest for the shortest holding period. When the holding period is assumed to be one week (1/4 of a month), the abnormal returns range from $10.34 \%$ to $19.12 \%$ on an annual basis, but they mostly disappear after the first three months ensuing the transaction date (i.e., holding periods exceeding three months). Both raw and abnormal returns are higher in Panels A and $\mathrm{C}$ than those in other panels. It appears that the magnitude of the abnormal returns depends more on the way that we weight returns across members than across transactions since in Panel A and C, the transactions are weighted differently (equal and by transaction size, respectively), but politician (or member)-level returns are equally weighted.

[Table 2.5 About Here] 
The raw and abnormal returns are lower and less significant when we weight politicianlevel returns by their portfolio size as reported in Panel B and D suggesting that there are politicians with losses on large portfolios bringing down the average returns. Furthermore, the results in Panel D are marginally significant only at one-week holding period where we weight transaction by their original amounts. In Panel D, large portfolios can be acquired with frequent trading and large trades, but in Panel B, the size of the transactions does not matter for the size of the portfolios since each transaction is assumed to be $\$ 1$. As a result, the poorer performance in Panel D should be at least partially caused by politicians with losses on large portfolios to which their large transactions have heavily contributed. These results overall suggest that $(i)$ politicians trade on time-sensitive value-relevant information, (ii) there are politicians with substantially large portfolios and large losses, and as long as we weight member-level returns equally, these losses do not impact the results, and (iii) there is an empirical support for Hypothesis 3 .

\subsubsection{Party Memberships}

In this section we investigate whether there are any information asymmetries between the members of the Democratic and Republican Parties. Under Hypothesis 4, we anticipate that the common stock portfolios of Republicans outperform those of Democrats. Panel A of Table 2.6 demonstrates the breakdown of the congressional trading data in terms of number of traders (politicians) and transactions. The number of Republicans outweighs that of Democrats by 64. Republicans also place more trades than Democrats on average.

\section{[Table 2.6 About Here]}

The results in Tables 2.7 and 2.8 present evidence in favor of Hypothesis 4 that the portfolio performance of Republicans is superior to that of Democrats with abnormal returns ranging from $16.57 \%$ to $28.25 \%$ under the one-week holding period. There is almost no 
evidence of informed trading for Democrats with mostly statistically insignificant abnormal returns.

[Table 2.7 About Here]

[Table 2.8 About Here]

\subsubsection{Powerful Politicians}

Hypothesis 5 predicts that the common stock portfolios of powerful politicians have higher abnormal returns than those of non-powerful politicians. We anticipate that the portfolios of powerful Republicans (Democrats) outperform those of non-powerful Republicans (Democrats). We provide the number of traders and transactions on the basis of party and power committee membership in Panel B and $\mathrm{C}$ of Table 2.6. The number of Republicans exceeds that of Democrats in both powerful and non-powerful samples. Furthermore, Republicans have more common stock transactions on average and in absolute number than Democrats.

We present the results in Table 2.9 and 2.10 only for powerful Republicans and Democrats, respectively. There is very weak evidence of informed trading for non-powerful Republicans and Democrats. While the portfolio performance of Republicans significantly improves when we go from non-powerful Republicans to powerful Republicans, there is almost no difference in the portfolio performance of powerful and non-powerful Democrats. These results suggest that being powerful enhances the portfolio performance of Republicans, but it has limited or no effect on Democrats.

[Table 2.9 About Here]

[Table 2.10 About Here] 
It is now evident that power is a determinant of the abnormal returns only when it interacts with the membership in the Republican Party.

\subsection{Information versus Skill}

We document that there are short-term abnormal returns on the congressional stock trades, and most of these returns are driven by powerful Republicans. Nevertheless, it is not conclusive yet whether powerful politicians get these abnormal returns thanks to their stock-picking skills or the use of private political information. Our results indicate that the nature of information in congressional stock trades is highly time-sensitive, but such a result still does not help us establish whether it is the skill or private political information generating the abnormal returns. In order to establish whether it is information or skill driving the abnormal returns, we need to separate politicians who are more experienced in trading stocks than other politicians. Seru et al. (RFS 2009) separate sophisticated retail traders from the rest based on whether a trader used options or not. They argue that "investors who trade options are likely to be more familiar with financial markets". We follow their approach and identify the powerful politicians who used options and/or short-selling in their trades, and call them sophisticated politicians.

Using the history of option trading/short-selling in identifying information- and skilldriven common stock trades has the following downside. It is possible that sophisticated traders exploit their informational advantage by trading through options, not common stocks. In case there are no or smaller abnormal returns on the portfolios of sophisticated traders, this weak performance can be explained by (relatively) weak trading skills or selective use of private information in option trades instead of regular common stock trades. Despite this downside, this methodology still allows us to separate information-driven common stock trades from regular common stock trades. If there are abnormal returns on the transac- 
tions by the sophisticated politicians, we can say that stock-picking skills contribute to these returns in addition to private political information. On the other hand, if it is the unsophisticated powerful politicians capturing the abnormal returns, then private political information is the main contributor to the abnormal returns for the unsophisticated politicians because they are more likely to resort to such information due to their lack of experience trading stocks.

There are 10,232 and 17,660 transactions in the sophisticated and unsophisticated sample, respectively. The number of sophisticated politicians is only 17 while the number of unsophisticated politicians is 146, which suggests that the sophisticated traders account for a large part of the full sample of the transactions despite representing less than $5 \%$ of all politicians in the sample. The results from Table 2.11 and 2.12 show that it is the powerful Republicans with less trading experience (i.e., unsophisticated) capturing most of the abnormal returns ranging from $34.68 \%$ to $47.23 \%$ on the annual basis under one-week holding period while the sophisticated ones have much weaker investment performance. Similar to the previous results, the abnormal returns disappear for holding periods exceeding three months.

\section{[Table 2.11 About Here]}

\section{[Table 2.12 About Here]}

Overall, there is evidence in favor of private political information embedded in congressional stock trades. It appears that additional trading for (perceived) skill-related reasons or the use of options in exploiting private information may have depressed the abnormal returns on the common stock investments of the sophisticated politicians. This result may not be surprising given that it is generally difficult to outperform the market by skill as in 
the case of mutual fund managers. ${ }^{21}$ However, it is possible to beat the market by using private information as in the case of corporate insiders (Jeng et al., 2003).

\subsection{Transaction Size Relative to Net Worth}

Our analysis presents evidence that unsophisticated powerful members of the Republican Party are the most informed traders of all in our sample. For this group of politicians, we now employ an additional layer of filter to separate high-information-content trades from low-information-content ones by scaling each trade with the inverse of politicians' net worth. We anticipate that the transactions that represent higher fraction of politicians' net worth contain more value-relevant information as politicians are more likely to play big when they have high quality information.

We obtain the net worth data from Center for Responsive Politics over the 2004-2010 period. We match a politician's net worth from the previous calendar year to her transactions in the current year so that current trading performance does not impact the level of net worth. As a result, we lose the transactions that members of Congress placed in year 2004 and end up with 13,941 transactions down from 17,660. Furthermore, we eliminate the trades from the politicians with negative net worth and the trades with extremely high ratio of transaction values (TV) to politicians' net worth (NW). We use 0.5 as a cut-off value to eliminate outliers. There are 296 transactions corresponding to the politicians with negative net worth and only three transactions with TV to NW ratio great or equal to 0.5.

\section{[Table 2.13 About Here]}

The remaining number of transactions is 13,642 , which we place in three terciles based

\footnotetext{
${ }^{21}$ http://business.time.com/2009/04/20/breaking-news-mutual-fund-managers-keep-failing-to-beat-themarket/
} 
on the TV/NW ratio. Next, we construct calendar-time portfolios for each tercile of the transactions. We report the estimation results in Table 2.13. To save space, we only report the abnormal returns based on the EW-MEW weighting scheme (transactions and returns are weighted equally) as the results based on the remaining weighting schemes are very similar. There seems to be an inverse U-shaped relationship between the TV/NW ratio and abnormal returns. The abnormal returns are the highest for the middle TV/NW tercile. We already anticipated lower abnormal returns for the bottom TV/NW tercile, but the weak abnormal returns for the top $\mathrm{TV} / \mathrm{NW}$ tercile are surprising. It is possible that the top tercile has transactions that politicians carry out as a result of irregular cash-flows such as buying a house or receiving an inheritance.

\subsection{Is It Really Power?}

In this section, we identify 50 powerful members of the Republican Party whose status shifted between powerful and non-powerful. These politicians have transactions from the periods that they were powerful and non-powerful. The comparison of their portfolio performances from these two distinct periods have the potential to illuminate the exact role of power in determining access to value-relevant information. EH (2013a) do not provide us with such insight since they assign all of a politician's transactions to the powerful sample as long as he serves on a powerful committee at some point during their sample period.

\section{[Table 2.14 About Here]}

These 50 politicians have a total of 20,799 and 4,233 transactions in the power and prepost power periods. The very same politicians traded almost five times more when they were powerful compared to the periods they were not powerful. We report the result of our power-based analysis in Table 2.14. There is a drastic change in the portfolio performance 
of the same politicians between the time they were in power and the time they were not. The abnormal returns in the power period exceed $30 \%$ under the one-week holding period while there is actually some evidence of underperformance in the non-power period.

\subsection{Is It Really Party Membership?}

Our main hypothesis anticipates that the members of the Republican Party are more informed than those of the Democratic Party. This hypothesis rests on the argument that the so-called Republican Revolution in the mid-90s changed the balance of power in Congress in favor of Republicans and encouraged closer ties with the business and lobbying community. It is possible that Republicans did not change the structure of Congress in such a way that they would be empowered with more value-relevant information than Democrats all the time. There could be time periods in which Democrats are also informed traders.

The informational advantage that Republicans enjoy could be restricted to the opportunities arising from being the majority party either in the House or the Senate. Separating the transactions into the periods based on which party controlled the House or the Senate has the potential to reveal whether the portfolios of Democrats outperform the market when the Democratic Party is the majority party. If being the majority party drives the superior trading performance, we will also expect that the portfolios of Republicans perform poorly when the Republican Party is not the majority party. Our sample period (2004-2010) presents us with clear-cut subsample periods to test this hypothesis. Republicans controlled the House and Senate for the 2004-2006 period while Democrats controlled these two chambers for the rest of the sample period. We call the 2004-2006 and the 2007-2010 intervals "Republican Majority" and "Democratic Majority" periods, respectively. We compare the portfolio performance of both powerful Republicans and Democrats in these two different periods. 


\section{[Table 2.15 About Here]}

We present the results of the party membership-majority control analysis in Table 2.15. In both Republican Majority and Democratic Majority samples, the portfolios of Republicans outperform those of Democrats. Despite the Democratic majority in both the House and Senate over the 2007-2010 period, Republicans continued making informed trades. On the other hand, there is no evidence of informed trading for Democrats even when they controlled both of the chambers. There is however weak evidence in favor of superior trading performance for Democrats during the Republican Majority period. Our paper is the first study in documenting that Republicans' informational advantage is not related to them being the majority party.

It is now clear that being the majority party does not explain the presence (lack of) of abnormal returns for Republicans (Democrats). Another possibility behind why we do not observe abnormal returns for the members of the Democratic Party could be related to the political alignment with the President's party (i.e., being from the same party). If the political alignment with the President explains the abnormal returns on congressional stock returns, we should observe that the portfolios of Democrats (Republicans) outperform the market during the Obama (Bush) presidency. In order to test this hypothesis, we compare the portfolio performance of powerful Republicans and Democrats during the Bush presidency (2004-2008) and the Obama presidency (2009-2010).

\section{[Table 2.16 About Here]}

The results in Table 2.16 show that Republicans do better when Bush was the president. On the contrary, the portfolios of Democrats do not outperform the market during the 
Obama presidency. There is actually some evidence that the portfolios of Republicans earn abnormal returns during the Obama presidency. These results suggest that Republicans benefit from having a Republican president in the White House while Democrats do not experience any meaningful change when the president is a Democrats in terms of their portfolios' performance. There is a similarity between the effect of power and that of presidential alignment on the portfolio performance of politicians: Power and presidential alignment both enhances only the portfolio returns of Republicans. Overall, these results support our earlier finding that the degree and presence of informed trading is an economically and statistically significant different between Republicans and Democrats.

Ziobrowski et al. (2011) show that for the 1985-2001 period, the portfolios of Democrats outperformed those of Republicans in the House of Representatives. They argue that “...when Republicans finally took control [of the House] in 1995, they arguably had far less

experience at handling the reins of power and may therefore have been unable to immediately enjoy all its perquisites." Our results suggest that in the post-2001 period, Republicans finally reaped the benefits of the drastic changes that they implemented in Congress following the so-called Republican Revolution.

\subsection{Is It Really Private Political Information?}

Our analysis of congressional stock portfolios finds that most of the abnormal returns are driven by private information as in the case of unsophisticated powerful Republicans. The implicit assumption behind this analysis is that private information in congressional stock trades has a political component. Nevertheless, it is possible that members of Congress may receive tips from various interest groups in exchange for political favors. The presence of such a relationship would suggest that members of Congress trade on private information, but this information is not generated by political decisions. 
Determining whether politicians trade on private political information requires the separation of congressional stock trades based on the likelihood of some trades being driven information that does not have political component. In order to make this distinction, we focus on the relationship the members of Congress and financial institutions that members of Congress use to trade stocks or that advise members of Congress on investing. We argue that financial institutions that work closely with politicians could share private information to make friends with politicians in anticipation of future favors. In other words, transactions that are associated with these financial institutions are more likely to contain private information with no political components whereas those that are not associated with any financial institution are more likely to contain private political information.

We identify the financial institutions that work closely with politicians based on whether politicians mention their names in their financial disclosure reports. Politicians must use financial institutions to trade stocks such as brokerage and investment firms, but only in some cases, they report the names of these financial institutions. The selective reporting of the names suggests that these institutions work closely with members of Congress when it comes to making trading decisions or filing financial disclosure reports. ${ }^{22}$ This is an imperfect measure of closeness as sometimes politicians make all of their investment decisions on their own even if they mention the name of a brokerage firm.

\section{[Table 2.17 About Here]}

We sort the transactions by the unsophisticated powerful Republicans into two portfolios based on our closeness indicator (connected and non-connected portfolios). We use 4,024

\footnotetext{
${ }^{22}$ Eggers and Hainmueller (2013a) state that when members of Congress mention the name of a financial institution, relevant transactions are directly reported by these financial institutions in the disclosure process. We could not independently verify this information. We only assume that these institutions help members of Congress in the disclosure and/or trading process to some extent.
} 
$(13,636)$ transactions in the construction of the connected (non-connected) portfolio. The results in Table 2.17 show that politicians are informed traders even when they do not work closely with a financial institution, which implies that at least some of congressional stock trades are driven by private political information.

\subsection{Conclusion}

We provide evidence that politicians trade on time-sensitive value-relevant information that is capable of predicting stock returns and generating abnormal returns in the short-term. The best performing group is the powerful politicians from the Republican Party with less trading experience (i.e., unsophisticated powerful Republicans) with abnormal returns exceeding $34 \%$ under the one-week holding period. It is not feasible to construct trading strategies based on congressional trading due to substantial lags between when these transactions take place and when the public become aware of them (5 to 17 months). The 2013 amendment of the STOCK Act prevents this valuable information from being incorporated into stock prices.

It is important to bear in mind that the use of private political information does not necessarily imply any illegal activity. It appears that politicians make informed bets thanks to their proximity to the decision making circles in Congress. It is possible that they predict

the future direction of legislation better than outsiders thanks to their deeper understanding of the political system and a rich network of connections. The fact that their transactions can predict the future stock returns even after three months following the transaction date suggests that politicians' informational advantage could be similar to that of corporate insiders who have a competitive edge over outsiders in putting the pieces together with the same amount of publicly available information (Seyhun, 2000). 


\section{Table 2.1: Descriptive Statistics}

This table presents the descriptive statistics of variables used in this analysis. The dependent variable, rret, is the firm-level monthly raw stock return in percentages. net3trade is the firm level trading index based on the congressional trading in the previous 3 months constructed according to Eq.(1). ret $_{-1}$ is the past month raw stock return, and ret $-2,-12$ is the cumulative continuously compounded returns from month $t-12$ to $t-2$ (both are in percentages). $\log ($ size) is the log of market capitalization (in millions) measured in June of each calendar year $T$, and $\log (\mathrm{bm})$ is the $\log$ of book-equity measured in December of calendar year $T-1$ for all fiscal years ending in calendar year $T-1$. Both $\log ($ size $)$ and $\log (\mathrm{bm})$ are attached to stock returns from July of year $T$ to June of year $T+1$. The transactions data is from Center for Responsive Politics, returns are from CRSP, and accounting data are from Compustat. We only keep the US domestic stocks (CRSP share code 10/11) listed on NYSE, AMEX, or NASDAQ. *, **, *** denote the 10,5 , and $1 \%$ significance levels.

Univariate Analysis

\begin{tabular}{llllll}
\hline Variables & Mean & Median & St Dev & Min & Max \\
\hline rret & 0.432 & 0.630 & 11.351 & -86.865 & 259.657 \\
net 3 trade $_{\text {ret }}$ & -0.017 & 0.000 & 0.832 & -1.000 & 1.000 \\
rret $_{-2,-12}$ & 0.657 & 0.724 & 11.716 & -86.865 & 259.657 \\
$\log _{(\text {size })}$ & 15.477 & 10.821 & 41.207 & -411.825 & 350.765 \\
$\log ($ bm $)$ & -0.963 & -0.937 & 0.796 & -8.924 & 2.821 \\
\hline
\end{tabular}

Correlation Analysis

\begin{tabular}{lllllll}
\hline Variables & rret & net3trade & rret $_{-1}$ & rret $_{-2,-12}$ & $\log ($ size $)$ & $\log (\mathrm{bm})$ \\
\hline rret & 1.0000 & & & & & \\
net $3 t r a d e$ & $0.024^{* * *}$ & 1.0000 & & & & \\
rret $_{-1}$ & $0.054^{* * *}$ & $0.028^{* * *}$ & 1.0000 & & & \\
rret $_{-2,-12}$ & $-0.010^{* *}$ & $0.054^{* * *}$ & $-0.016^{* * *}$ & 1.0000 & & \\
$\log \left(\right.$ size $\left.^{*}\right)$ & -0.006 & $-0.037^{* * *}$ & $-0.024^{* * *}$ & $-0.056^{* * *}$ & 1.0000 & \\
$\log (\mathrm{bm})$ & $0.019^{* * *}$ & $-0.015^{* * *}$ & $0.025^{* * *}$ & $0.025^{* * *}$ & $-0.125^{* * *}$ & 1.0000 \\
\hline
\end{tabular}




\section{Table 2.2: Firm-Level Prediction}

This table presents the pooled regression results using all congressional stock trades over 2004M022011M01 for all, small mcap, and big mcap companies. Dependent variable, rret, is raw stock returns in \%. net3trade (net6trade) is firm-level trading index based on the congressional trading in the previous 3 (6) months (Eq. 1). full3trade is the same as net3trade, but replaces the missing index values with zeros. ret $_{-1}$ is the past month raw return and ret $_{-2,-12}$ is the cumulative continuously compounded returns from month $t-12$ to $t-2 \cdot \log ($ size $)$ is the $\log$ of market capitalization (in millions) measured in June of each calendar year $T$, and $\log (\mathrm{bm})$ is the $\log$ of book-equity measured in December of calendar year $T-1$ for all fiscal years ending in calendar year $T-1 . \log (\operatorname{size})$ and $\log (b m)$ are attached to stock returns from July of year $T$ to June of year $T+1$. The transactions data is from Center for Responsive Politics, returns from CRSP, and accounting data from Compustat. We only keep the US domestic stocks (CRSP share code 10/11) listed on NYSE, AMEX, or NASDAQ. ${ }^{*},{ }^{* *},{ }^{* * *}$ are the 10,5 , and 1 $\%$ significance levels. Results with month-fixed effects (FEs) are reported in even numbered columns. Standard errors are clustered at the firm-level (t-statistics in parenthesis). Intercepts are not presented.

\begin{tabular}{|c|c|c|c|c|c|c|}
\hline & $(1)$ & $(2)$ & $(3)$ & $(4)$ & $(5)$ & $(6)$ \\
\hline Vars / Sample & All & All & Small & Small & Big & Big \\
\hline \multicolumn{7}{|c|}{ Panel A: net3trade } \\
\hline net3trade & $\begin{array}{l}0.322^{* * *} \\
(5.06)\end{array}$ & $\begin{array}{l}0.169^{* * *} \\
(2.89)\end{array}$ & $\begin{array}{l}0.416^{* * *} \\
(3.17)\end{array}$ & $\begin{array}{l}0.315^{* *} \\
(2.54)\end{array}$ & $\begin{array}{l}0.271^{* * *} \\
(3.91)\end{array}$ & $\begin{array}{l}0.099 \\
(1.59)\end{array}$ \\
\hline$r_{-1}$ & $\begin{array}{l}0.051^{* * *} \\
(5.85)\end{array}$ & $\begin{array}{l}-0.001 \\
(-0.09)\end{array}$ & $\begin{array}{l}0.013 \\
(0.93)\end{array}$ & $\begin{array}{l}-0.011 \\
(-0.84)\end{array}$ & $\begin{array}{l}0.078^{* * *} \\
(7.21)\end{array}$ & $\begin{array}{l}0.010 \\
(0.80)\end{array}$ \\
\hline$r_{-2,-12}$ & $\begin{array}{l}-0.003 \\
(-1.25)\end{array}$ & $\begin{array}{l}-0.003 \\
(-1.20)\end{array}$ & $\begin{array}{l}-0.002 \\
(-0.61)\end{array}$ & $\begin{array}{l}-0.001 \\
(-0.23)\end{array}$ & $\begin{array}{l}-0.004 \\
(-1.30)\end{array}$ & $\begin{array}{l}-0.006 \\
(-1.37)\end{array}$ \\
\hline $\log (\operatorname{size})$ & $\begin{array}{l}-0.019 \\
(-0.54)\end{array}$ & $\begin{array}{l}-0.028 \\
(-0.83)\end{array}$ & $\begin{array}{c}-0.314^{*} \\
(-1.79)\end{array}$ & $\begin{array}{l}-0.014 \\
(-0.08)\end{array}$ & $\begin{array}{l}-0.135^{* * *} \\
(-2.90)\end{array}$ & $\begin{array}{l}-0.077^{*} \\
(-1.74)\end{array}$ \\
\hline $\log (b m)$ & $\begin{array}{l}0.255^{* * *} \\
(3.61)\end{array}$ & $\begin{array}{l}0.088 \\
(1.29)\end{array}$ & $\begin{array}{l}0.373^{* *} \\
(2.08)\end{array}$ & $\begin{array}{l}0.203 \\
(1.19)\end{array}$ & $\begin{array}{l}0.193^{* * *} \\
(2.85)\end{array}$ & $\begin{array}{l}0.032 \\
(0.47)\end{array}$ \\
\hline Obs. & 49,081 & 49,081 & 13,214 & 13,214 & 35,867 & 35,867 \\
\hline \multicolumn{7}{|c|}{ Panel B: full3trade } \\
\hline full3trade & $\begin{array}{l}0.341^{* * *} \\
(5.37)\end{array}$ & $\begin{array}{l}0.139^{* *} \\
(2.39)\end{array}$ & $\begin{array}{l}0.446^{* * *} \\
(3.45)\end{array}$ & $\begin{array}{l}0.337^{* * *} \\
(2.78)\end{array}$ & $\begin{array}{l}0.281^{* * *} \\
(4.09)\end{array}$ & $\begin{array}{l}0.087 \\
(1.42)\end{array}$ \\
\hline$r_{-1}$ & $\begin{array}{l}0.040^{* * *} \\
(8.69)\end{array}$ & $\begin{array}{l}-0.006 \\
(-1.35)\end{array}$ & $\begin{array}{l}0.030^{* * *} \\
(5.65)\end{array}$ & $\begin{array}{l}-0.010^{*} \\
(-1.92)\end{array}$ & $\begin{array}{l}0.077^{* * *} \\
(11.77)\end{array}$ & $\begin{array}{l}0.006 \\
(0.91)\end{array}$ \\
\hline$r_{-2,-12}$ & $\begin{array}{l}-0.012^{* * *} \\
(-9.44)\end{array}$ & $\begin{array}{l}-0.011^{* * *} \\
(-7.82)\end{array}$ & $\begin{array}{l}-0.011^{* * *} \\
(-6.94)\end{array}$ & $\begin{array}{l}-0.010^{* * *} \\
(-5.51)\end{array}$ & $\begin{array}{l}-0.014^{* * *} \\
(-7.45)\end{array}$ & $\begin{array}{l}-0.015^{* * *} \\
(-5.76)\end{array}$ \\
\hline $\log (\operatorname{size})$ & $\begin{array}{l}-0.204^{* * *} \\
(-8.91)\end{array}$ & $\begin{array}{l}-0.186^{* * * *} \\
(-8.36)\end{array}$ & $\begin{array}{l}-0.466^{* * *} \\
(-7.28)\end{array}$ & $\begin{array}{l}-0.319^{* * *} \\
(-5.09)\end{array}$ & $\begin{array}{l}-0.290^{* * *} \\
(-8.73)\end{array}$ & $\begin{array}{l}-0.154^{* * *} \\
(-4.87)\end{array}$ \\
\hline $\log (b m)$ & $\begin{array}{l}0.341 * * * \\
(7.01)\end{array}$ & $\begin{array}{l}0.104^{* *} \\
(2.18)\end{array}$ & $\begin{array}{l}0.334^{* * *} \\
(4.70)\end{array}$ & $\begin{array}{l}0.085 \\
(1.22)\end{array}$ & $\begin{array}{l}0.253^{* * *} \\
(4.97)\end{array}$ & $\begin{array}{l}0.042 \\
(0.84)\end{array}$ \\
\hline \multirow[t]{2}{*}{ Obs. } & 177,091 & 177,091 & 105,086 & 105,086 & 72,005 & 72,005 \\
\hline & & Panel & ב: net6trad & & & \\
\hline net6trade & $\begin{array}{l}0.298^{* * *} \\
(4.87)\end{array}$ & $\begin{array}{l}0.085 \\
(1.54)\end{array}$ & $\begin{array}{l}0.313^{* * *} \\
(2.81)\end{array}$ & $\begin{array}{l}0.120 \\
(1.16)\end{array}$ & $\begin{array}{l}0.273^{* * *} \\
(3.92)\end{array}$ & $\begin{array}{l}0.065 \\
(1.05)\end{array}$ \\
\hline$r_{-1}$ & $\begin{array}{l}0.048^{* * *} \\
(7.05)\end{array}$ & $\begin{array}{l}0.001 \\
(0.10)\end{array}$ & $\begin{array}{l}0.016 \\
(1.47)\end{array}$ & $\begin{array}{l}-0.005 \\
(-0.53)\end{array}$ & $\begin{array}{l}0.079 * * * \\
(9.20)\end{array}$ & $\begin{array}{l}0.010 \\
(1.03)\end{array}$ \\
\hline$r_{-2,-12}$ & $\begin{array}{l}-0.006^{* * *} \\
(-2.91)\end{array}$ & $\begin{array}{l}-0.005^{* *} \\
(-2.23)\end{array}$ & $\begin{array}{l}-0.002 \\
(-0.53)\end{array}$ & $\begin{array}{l}-0.000 \\
(-0.02)\end{array}$ & $\begin{array}{l}-0.009^{* * *} \\
(-3.54)\end{array}$ & $\begin{array}{l}-0.010^{* * *} \\
(-2.97)\end{array}$ \\
\hline $\log (\operatorname{size})$ & $\begin{array}{l}-0.036 \\
(-1.21)\end{array}$ & $\begin{array}{l}-0.025 \\
(-0.86)\end{array}$ & $\begin{array}{l}-0.174 \\
(-1.38)\end{array}$ & $\begin{array}{l}0.120 \\
(0.95)\end{array}$ & $\begin{array}{l}-0.204^{* * *} \\
(-4.94)\end{array}$ & $\begin{array}{l}-0.114^{* * *} \\
(-2.89)\end{array}$ \\
\hline $\log (b m)$ & $\begin{array}{l}0.277^{* * *} \\
(4.49)\end{array}$ & $\begin{array}{l}0.089 \\
(1.49)\end{array}$ & $\begin{array}{l}0.296^{* *} \\
(2.07)\end{array}$ & $\begin{array}{l}0.105 \\
(0.77)\end{array}$ & $\begin{array}{l}0.251^{* * * *} \\
(3.98)\end{array}$ & $\begin{array}{l}0.072 \\
(1.17)\end{array}$ \\
\hline Obs. & 67,369 & 67,369 & 21,815 & 21,815 & 45,554 & 45,554 \\
\hline FEs (all panels) & No & Yes & No & Yes & No & Yes \\
\hline
\end{tabular}




\section{Table 2.3: Firm-Level Prediction: Sub-Period Analysis}

This table presents the pooled regression results using all congressional stock trades over 2004M022011M01 for all, small mcap, and big mcap companies for three different subperiods. Dependent variable, rret, is raw stock returns in percentages. net3trade is firm-level trading index based on the congressional trading in the previous 3 months (Eq. 1). ret $_{-1}$ is the past month raw return and ret re-12 $_{-12}$ is the cumulative continuously compounded returns from month $t-12$ to $t-2$. $\log ($ size $)$ is the $\log$ of market capitalization (in millions) measured in June of each calendar year $T$, and $\log (b m)$ is the $\log$ of bookequity measured in December of calendar year $T-1$ for all fiscal years ending in calendar year $T-1$. $\log ($ size $)$ and $\log (\mathrm{bm})$ are attached to stock returns from July of year $T$ to June of year $T+1$. The transactions data is from Center for Responsive Politics, returns from CRSP, and accounting data from Compustat. We only keep the US domestic stocks (CRSP share code 10/11) listed on NYSE, AMEX, or NASDAQ. ${ }^{*},{ }^{* *},{ }^{* * *}$ are the 10,5 , and $1 \%$ significance levels. Results with month-fixed effects (FEs) are reported in even numbered columns. Standard errors are clustered at the firm-level (t-statistics in parenthesis). Intercepts are not presented.

\begin{tabular}{|c|c|c|c|c|c|c|}
\hline & $(1)$ & $(2)$ & $(3)$ & $(4)$ & $(5)$ & $(6)$ \\
\hline Vars / Sample & All & All & Small & Small & Big & Big \\
\hline \multicolumn{7}{|c|}{ Panel A: Pre-Recession Period } \\
\hline net3trade & $\begin{array}{l}0.242^{* * *} \\
(3.72)\end{array}$ & $\begin{array}{l}0.172^{* * *} \\
(2.75)\end{array}$ & $\begin{array}{l}0.281^{* *} \\
(2.12)\end{array}$ & $\begin{array}{l}0.280^{* *} \\
(2.20)\end{array}$ & $\begin{array}{l}0.226^{* * *} \\
(3.34)\end{array}$ & $\begin{array}{l}0.118^{*} \\
(1.82)\end{array}$ \\
\hline$r_{-1}$ & $\begin{array}{l}0.010 \\
(1.25)\end{array}$ & $\begin{array}{l}0.004 \\
(0.44)\end{array}$ & $\begin{array}{l}-0.016 \\
(-1.27)\end{array}$ & $\begin{array}{l}-0.023^{*} \\
(-1.81)\end{array}$ & $\begin{array}{l}0.038^{* * * *} \\
(4.11)\end{array}$ & $\begin{array}{l}0.033^{* * *} \\
(3.64)\end{array}$ \\
\hline$r_{-2,-12}$ & $\begin{array}{l}-0.005^{*} \\
(-1.84)\end{array}$ & $\begin{array}{l}0.005^{*} \\
(1.83)\end{array}$ & $\begin{array}{l}-0.008^{*} \\
(-1.90)\end{array}$ & $\begin{array}{l}0.001 \\
(0.36)\end{array}$ & $\begin{array}{l}-0.002 \\
(-0.79)\end{array}$ & $\begin{array}{l}0.009^{* * *} \\
(2.78)\end{array}$ \\
\hline $\log ($ size $)$ & $\begin{array}{l}0.026 \\
(0.69)\end{array}$ & $\begin{array}{l}0.033 \\
(0.92)\end{array}$ & $\begin{array}{l}-0.275 \\
(-1.58)\end{array}$ & $\begin{array}{l}-0.014 \\
(-0.08)\end{array}$ & $\begin{array}{l}-0.009 \\
(-0.18)\end{array}$ & $\begin{array}{l}0.009 \\
(0.20)\end{array}$ \\
\hline $\log (b m)$ & $\begin{array}{l}0.137^{*} \\
(1.67)\end{array}$ & $\begin{array}{l}0.145^{*} \\
(1.85)\end{array}$ & $\begin{array}{l}0.231 \\
(1.15)\end{array}$ & $\begin{array}{l}0.213 \\
(1.15)\end{array}$ & $\begin{array}{l}0.082 \\
(1.03)\end{array}$ & $\begin{array}{l}0.109 \\
(1.44)\end{array}$ \\
\hline Obs. & 30,517 & 30,517 & 9,077 & 9,077 & 21,440 & 21,440 \\
\hline \multicolumn{7}{|c|}{ Panel B: Recessionary Period } \\
\hline net3trade & $\begin{array}{l}0.796^{* * *} \\
(3.77)\end{array}$ & $\begin{array}{l}0.340^{*} \\
(1.69)\end{array}$ & $\begin{array}{l}0.597 \\
(1.30)\end{array}$ & $\begin{array}{l}0.523 \\
(1.19)\end{array}$ & $\begin{array}{l}0.876^{* * * *} \\
(3.78)\end{array}$ & $\begin{array}{l}0.262 \\
(1.19)\end{array}$ \\
\hline$r_{-1}$ & $\begin{array}{l}0.090^{* * *} \\
(5.15)\end{array}$ & $\begin{array}{l}0.014 \\
(0.71)\end{array}$ & $\begin{array}{l}0.062^{*} \\
(1.90)\end{array}$ & $\begin{array}{l}0.025 \\
(0.74)\end{array}$ & $\begin{array}{l}0.106^{* * * *} \\
(5.15)\end{array}$ & $\begin{array}{l}0.011 \\
(0.48)\end{array}$ \\
\hline$r_{-2,-12}$ & $\begin{array}{l}-0.035 * * * \\
(-5.85)\end{array}$ & $\begin{array}{l}-0.014^{* *} \\
(-2.20)\end{array}$ & $\begin{array}{l}-0.021^{* *} \\
(-2.20)\end{array}$ & $\begin{array}{l}-0.004 \\
(-0.46)\end{array}$ & $\begin{array}{l}-0.042^{* * *} \\
(-5.34)\end{array}$ & $\begin{array}{l}-0.019 * * \\
(-2.17)\end{array}$ \\
\hline $\log ($ size $)$ & $\begin{array}{l}0.173 \\
(1.59)\end{array}$ & $\begin{array}{l}0.042 \\
(0.40)\end{array}$ & $\begin{array}{l}0.339 \\
(0.48)\end{array}$ & $\begin{array}{l}0.102 \\
(0.16)\end{array}$ & $\begin{array}{l}0.302^{* *} \\
(2.23)\end{array}$ & $\begin{array}{l}0.133 \\
(1.09)\end{array}$ \\
\hline $\log (b m)$ & $\begin{array}{l}-0.787^{* * * *} \\
(-3.61)\end{array}$ & $\begin{array}{l}-0.491 * * \\
(-2.47)\end{array}$ & $\begin{array}{l}-0.598 \\
(-0.99)\end{array}$ & $\begin{array}{l}-0.279 \\
(-0.48)\end{array}$ & $\begin{array}{l}-0.832^{* * *} \\
(-3.69)\end{array}$ & $\begin{array}{l}-0.580 \text { *** } \\
(-2.91)\end{array}$ \\
\hline \multirow[t]{2}{*}{ Obs. } & 9,508 & 9,508 & 2,347 & 2,347 & 7,161 & 7,161 \\
\hline & & nel C: Post & Recession I & riod & & \\
\hline net3trade & $\begin{array}{l}0.011 \\
(0.08)\end{array}$ & $\begin{array}{l}-0.005 \\
(-0.04)\end{array}$ & $\begin{array}{l}0.140 \\
(0.35)\end{array}$ & $\begin{array}{l}0.214 \\
(0.60)\end{array}$ & $\begin{array}{l}-0.030 \\
(-0.22)\end{array}$ & $\begin{array}{l}-0.061 \\
-0.50)\end{array}$ \\
\hline$r_{-1}$ & $\begin{array}{l}-0.090 * * * \\
(-5.96)\end{array}$ & $\begin{array}{l}-0.061^{* * *} \\
(-3.15)\end{array}$ & $\begin{array}{l}-0.082^{* * *} \\
(-2.86)\end{array}$ & $\begin{array}{l}-0.052^{*} \\
(-1.68)\end{array}$ & $\begin{array}{l}-0.098^{* * *} \\
(-5.53)\end{array}$ & $\begin{array}{l}-0.068^{* * *} \\
(-2.74)\end{array}$ \\
\hline$r_{-2,-12}$ & $\begin{array}{l}-0.023 * * * \\
(-4.05)\end{array}$ & $\begin{array}{l}-0.009 \\
(-1.40)\end{array}$ & $\begin{array}{l}-0.013^{*} \\
(-1.75)\end{array}$ & $\begin{array}{l}-0.004 \\
(-0.47)\end{array}$ & $\begin{array}{l}-0.032^{* * *} \\
(-4.17)\end{array}$ & $\begin{array}{l}-0.015 \\
(-1.57)\end{array}$ \\
\hline $\log ($ size $)$ & $\begin{array}{l}-0.266^{* * * *} \\
(-3.08)\end{array}$ & $\begin{array}{l}-0.326^{* * * *} \\
(-3.99)\end{array}$ & $\begin{array}{l}0.268 \\
(0.58)\end{array}$ & $\begin{array}{l}-0.212 \\
(-0.49)\end{array}$ & $\begin{array}{l}-0.472^{* * * *} \\
(-4.94)\end{array}$ & $\begin{array}{l}-0.474^{* * *} \\
(-5.19)\end{array}$ \\
\hline $\log (b m)$ & $\begin{array}{l}0.003 \\
(0.02)\end{array}$ & $\begin{array}{l}0.272^{*} \\
(1.68)\end{array}$ & $\begin{array}{l}0.493 \\
(1.24)\end{array}$ & $\begin{array}{l}0.571 \\
(1.47)\end{array}$ & $\begin{array}{l}-0.188 \\
(-0.99)\end{array}$ & $\begin{array}{l}0.116 \\
(0.70)\end{array}$ \\
\hline Obs. & 9,056 & 9,056 & 1,790 & 1,790 & 7,266 & 7,266 \\
\hline FEs (all panels) & No & Yes & No & Yes & No & Yes \\
\hline
\end{tabular}




\section{Table 2.4: Firm-Level Prediction: Illiquidity Filtered}

This table presents the pooled regression results using all congressional stock trades over 2004M022011M01 for all, small, and big mcap companies. Dependent variable, rret, is raw stock returns in $\%$. net3trade (net6trade) is firm-level trading index based on the congressional trading in the previous 3 (6) months (Eq. 1). full3trade replaces the missing value of net3trade with zeros. We combine multiple trades in a month into a single trade in relatively illiquid firms. ret $_{-1}$ is the past month raw return and ret $_{-2,-12}$ is the cumulative continuously compounded returns from month $t-12$ to $t-2$. $\log ($ size $)$ is the $\log$ of market capitalization (in millions) measured in June of each calendar year $T$, and $\log (\mathrm{bm})$ is the $\log$ of book-equity measured in December of calendar year $T-1$ for all fiscal years ending in calendar year $T-1$. $\log ($ size $)$ and $\log (\mathrm{bm})$ are attached to stock returns from July of year $T$ to June of year $T+1$. The transactions data is from Center for Responsive Politics, returns from CRSP, and accounting data from Compustat. We only keep the domestic NYSE/AMEX/NASDAQ stocks. *, **, *** are 10, 5 , and $1 \%$ significance levels. Results with month-fixed effects (FEs) are reported in even numbered columns. SEs are clustered at the firm-level (t-statistics in parenthesis). Intercepts are not presented.

\begin{tabular}{|c|c|c|c|c|c|c|}
\hline & $(1)$ & $(2)$ & $(3)$ & $(4)$ & $(5)$ & (6) \\
\hline Vars / Sample & All & All & Small & Small & Big & Big \\
\hline \multicolumn{7}{|c|}{ Panel A: net3trade } \\
\hline net3trade & $\begin{array}{l}0.326^{* * *} \\
(5.13)\end{array}$ & $\begin{array}{l}0.172^{* * *} \\
(2.94)\end{array}$ & $\begin{array}{l}0.421^{* * *} \\
(3.21)\end{array}$ & $\begin{array}{l}0.318^{* *} \\
(2.56)\end{array}$ & $\begin{array}{l}0.274^{* * *} \\
(3.95)\end{array}$ & $\begin{array}{l}0.101 \\
(1.63)\end{array}$ \\
\hline$r_{-1}$ & $\begin{array}{l}0.051^{* * *} \\
(5.85)\end{array}$ & $\begin{array}{l}-0.001 \\
(-0.10)\end{array}$ & $\begin{array}{l}0.013 \\
(0.93)\end{array}$ & $\begin{array}{l}-0.011 \\
(-0.84)\end{array}$ & $\begin{array}{l}0.078^{* * *} \\
(7.21)\end{array}$ & $\begin{array}{l}0.010 \\
(0.80)\end{array}$ \\
\hline$r_{-2,-12}$ & $\begin{array}{l}-0.003 \\
(-1.25)\end{array}$ & $\begin{array}{l}-0.003 \\
(-1.20)\end{array}$ & $\begin{array}{l}-0.002 \\
(-0.60)\end{array}$ & $\begin{array}{l}-0.001 \\
(-0.22)\end{array}$ & $\begin{array}{l}-0.004 \\
(-1.29)\end{array}$ & $\begin{array}{l}-0.006 \\
(-1.38)\end{array}$ \\
\hline $\log (s i z e)$ & $\begin{array}{l}-0.019 \\
(-0.53)\end{array}$ & $\begin{array}{l}-0.028 \\
(-0.82)\end{array}$ & $\begin{array}{c}-0.313^{*} \\
(-1.78)\end{array}$ & $\begin{array}{l}-0.014 \\
(-0.08)\end{array}$ & $\begin{array}{l}-0.135^{* * *} \\
(-2.90)\end{array}$ & $\begin{array}{l}-0.077^{*} \\
-1.74)\end{array}$ \\
\hline $\log (b m)$ & $\begin{array}{l}0.256^{* * *} \\
(3.63)\end{array}$ & $\begin{array}{l}0.088 \\
(1.29)\end{array}$ & $\begin{array}{l}0.372^{* *} \\
(2.07)\end{array}$ & $\begin{array}{l}0.203 \\
(1.18)\end{array}$ & $\begin{array}{l}0.195^{* * * *} \\
(2.88)\end{array}$ & $\begin{array}{l}0.033 \\
(0.48)\end{array}$ \\
\hline Obs. & 49,075 & 49,075 & 13,212 & 13,212 & 35,863 & 35,863 \\
\hline \multicolumn{7}{|c|}{ Panel B: full3trade } \\
\hline full3trade & $\begin{array}{l}0.344^{* * *} \\
(5.43)\end{array}$ & $\begin{array}{l}0.141^{* *} \\
(2.43)\end{array}$ & $\begin{array}{l}0.450^{* * *} \\
(3.48)\end{array}$ & $\begin{array}{l}0.341^{* * *} \\
(2.82)\end{array}$ & $\begin{array}{l}0.284^{* * *} \\
(4.13)\end{array}$ & $\begin{array}{l}0.089 \\
(1.45)\end{array}$ \\
\hline$r_{-1}$ & $\begin{array}{l}0.040^{* * *} \\
(8.67)\end{array}$ & $\begin{array}{l}-0.006 \\
(-1.37)\end{array}$ & $\begin{array}{l}0.030^{* * *} \\
(5.62)\end{array}$ & $\begin{array}{l}-0.010^{*} \\
-1.94)\end{array}$ & $\begin{array}{l}0.077^{* * *} \\
(11.77)\end{array}$ & $\begin{array}{l}0.006 \\
(0.91)\end{array}$ \\
\hline$r_{-2,-12}$ & $\begin{array}{l}-0.012^{* * *} \\
(-9.41)\end{array}$ & $\begin{array}{l}-0.011^{* * * *} \\
(-7.78)\end{array}$ & $\begin{array}{l}-0.011^{* * *} \\
(-6.90)\end{array}$ & $\begin{array}{l}-0.010^{* * *} \\
(-5.48)\end{array}$ & $\begin{array}{l}-0.014^{* * *} \\
(-7.45)\end{array}$ & $\begin{array}{l}-0.015^{* * *} \\
(-5.76)\end{array}$ \\
\hline $\log (s i z e)$ & $\begin{array}{l}-0.204^{* * *} \\
(-8.90)\end{array}$ & $\begin{array}{l}-0.186^{* * *} \\
(-8.35)\end{array}$ & $\begin{array}{l}-0.466^{* * *} \\
(-7.28)\end{array}$ & $\begin{array}{l}-0.319^{* * *} \\
(-5.09)\end{array}$ & $\begin{array}{l}-0.290^{* * *} \\
(-8.73)\end{array}$ & $\begin{array}{l}-0.154^{* * *} \\
(-4.87)\end{array}$ \\
\hline $\log (b m)$ & $\begin{array}{l}0.339^{* * *} \\
(6.97)\end{array}$ & $\begin{array}{l}0.102^{* *} \\
(2.15)\end{array}$ & $\begin{array}{l}0.330^{* * *} \\
(4.64)\end{array}$ & $\begin{array}{l}0.083 \\
(1.18)\end{array}$ & $\begin{array}{l}0.253^{* * *} \\
(4.97)\end{array}$ & $\begin{array}{l}0.042 \\
(0.84)\end{array}$ \\
\hline \multirow[t]{2}{*}{ Obs. } & 177,022 & 177,022 & 105,017 & 105,017 & 72,005 & 72,005 \\
\hline & & Panel & C: net6trad & & & \\
\hline net6trade & $\begin{array}{l}0.302^{* * *} \\
(4.91)\end{array}$ & $\begin{array}{l}0.090 \\
(1.62)\end{array}$ & $\begin{array}{l}0.317^{* * *} \\
(2.84)\end{array}$ & $\begin{array}{l}0.129 \\
(1.24)\end{array}$ & $\begin{array}{l}0.276^{* * *} \\
(3.96)\end{array}$ & $\begin{array}{l}0.067 \\
(1.09)\end{array}$ \\
\hline$r_{-1}$ & $\begin{array}{l}0.048^{* * *} \\
(7.05)\end{array}$ & $\begin{array}{l}0.001 \\
(0.10)\end{array}$ & $\begin{array}{l}0.016 \\
(1.47)\end{array}$ & $\begin{array}{l}-0.005 \\
(-0.53)\end{array}$ & $\begin{array}{l}0.079^{* * *} \\
(9.20)\end{array}$ & $\begin{array}{l}0.010 \\
(1.03)\end{array}$ \\
\hline$r_{-2,-12}$ & $\begin{array}{l}-0.006^{* * *} \\
(-2.91)\end{array}$ & $\begin{array}{l}-0.005^{* *} \\
(-2.23)\end{array}$ & $\begin{array}{l}-0.002 \\
(-0.52)\end{array}$ & $\begin{array}{l}-0.000 \\
(-0.02)\end{array}$ & $\begin{array}{l}-0.009^{* * *} \\
(-3.54)\end{array}$ & $\begin{array}{l}-0.010^{* * *} \\
(-2.98)\end{array}$ \\
\hline $\log (\operatorname{size})$ & $\begin{array}{l}-0.036 \\
(-1.20)\end{array}$ & $\begin{array}{l}-0.025 \\
(-0.86)\end{array}$ & $\begin{array}{l}-0.174 \\
(-1.38)\end{array}$ & $\begin{array}{l}0.120 \\
(0.95)\end{array}$ & $\begin{array}{l}-0.204^{* * * *} \\
(-4.94)\end{array}$ & $\begin{array}{l}-0.114^{* * *} \\
(-2.89)\end{array}$ \\
\hline $\log (b m)$ & $\begin{array}{l}0.278^{* * *} \\
(4.50)\end{array}$ & $\begin{array}{l}0.089 \\
(1.50)\end{array}$ & $\begin{array}{l}0.296^{* *} \\
(2.07)\end{array}$ & $\begin{array}{l}0.105 \\
(0.77)\end{array}$ & $\begin{array}{l}0.252^{* * *} \\
(4.00)\end{array}$ & $\begin{array}{l}0.073 \\
(1.17)\end{array}$ \\
\hline Obs. & 63,364 & 63,364 & 21,814 & 21,814 & 45,550 & 45,550 \\
\hline FEs (all panels) & No & Yes & No & Yes & No & Yes \\
\hline
\end{tabular}




\section{Figure 2.1: Calendar Time Portfolio Chart}

This chart presents the four different weighting schemes used to calculate the calendar-time portfolio returns.

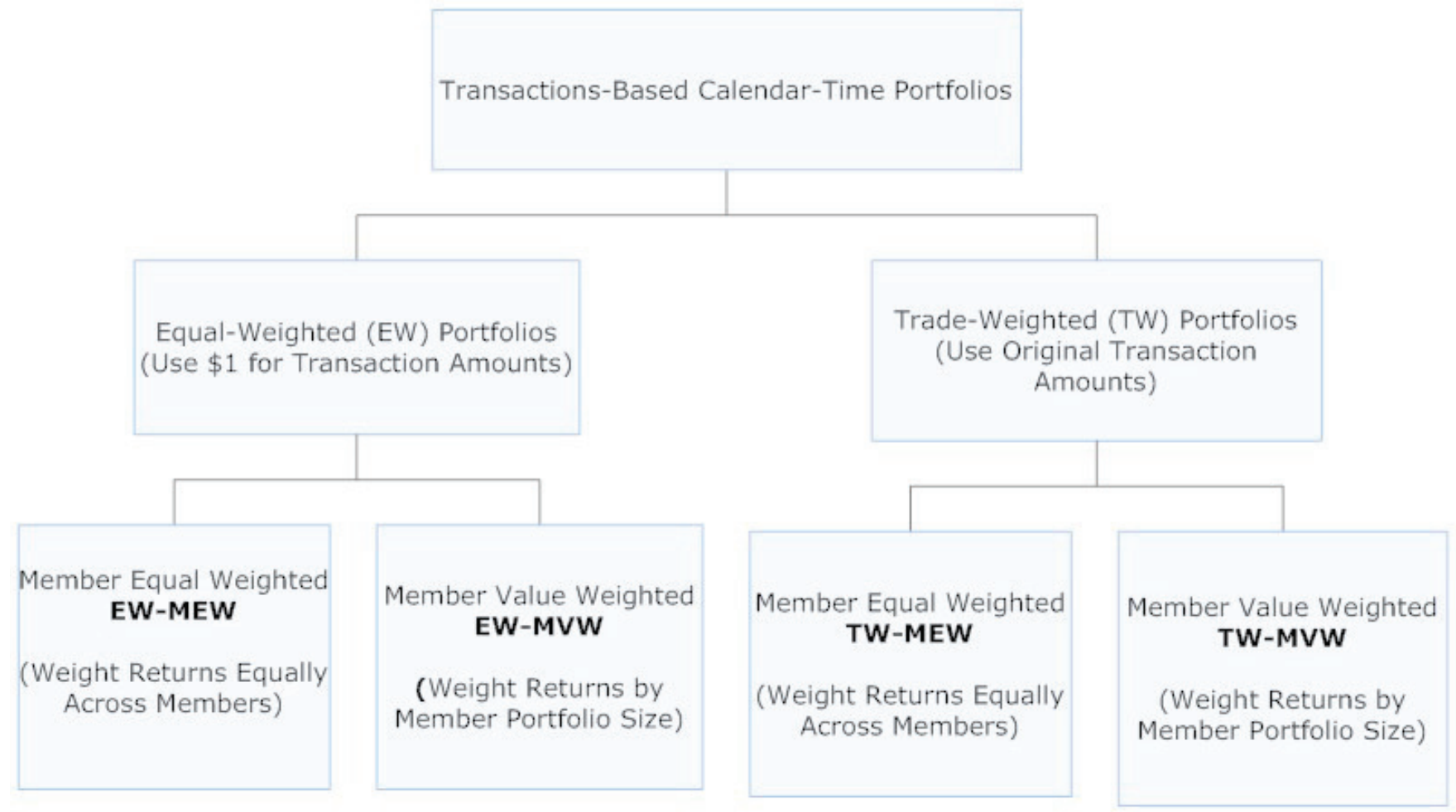




\section{Table 2.5: Alphas on Long/Short (Buy-Minus-Sell) Portfolio: Full Sample}

This table presents average monthly raw and risk-adjusted returns (alphas) in percentages over 2004M01-2011M12 period on the long/short (buy-minus-sell) portfolios from the transactions in NYSE/AMEX/NASDAQ stocks by members of Congress. Transactions data is from Center for Responsive Politics, stock returns from CRSP, and five factors and risk-free rate from WRDS. Daily portfolio returns are calculated using four different weighting schemes under holding periods from 1 week to 12 months and compounded to monthly returns. Newey-West robust t-statistics (three lags) are in parenthesis. $*, * *, * * *$ denote the 10,5 , and $1 \%$ significance levels.

\begin{tabular}{|c|c|c|c|c|c|c|}
\hline Holding Period (Months): & $1 / 4$ & 1 & 2 & 3 & 6 & 12 \\
\hline \multicolumn{7}{|c|}{ Panel A: Equal-Weighted Transactions and Equal-Weighted Portfolios (EW-MEW) } \\
\hline \multirow[t]{2}{*}{ Avg. Return } & $1.423^{* * *}$ & 0.305 & $0.364^{*}$ & 0.246 & -0.011 & -0.039 \\
\hline & $(3.38)$ & $(1.44)$ & $(1.85)$ & $(1.41)$ & $(-0.07)$ & $(-0.32)$ \\
\hline \multirow[t]{2}{*}{ CAPM Alpha } & $1.538^{* * *}$ & $0.365^{* *}$ & $0.398^{* *}$ & $0.277^{*}$ & 0.004 & -0.020 \\
\hline & $(4.33)$ & $(2.18)$ & $(2.40)$ & $(1.75)$ & $(0.03)$ & $(-0.18)$ \\
\hline \multirow{2}{*}{ FF Alpha } & $1.511^{* * *}$ & $0.356^{*}$ & $0.427^{* * *}$ & $0.329^{* *}$ & 0.042 & -0.007 \\
\hline & $(4.27)$ & $(1.87)$ & $(2.82)$ & $(2.36)$ & $(0.34)$ & $(-0.07)$ \\
\hline \multirow[t]{2}{*}{ Carhart Alpha } & $1.508^{* * *}$ & $0.352^{*}$ & $0.418^{* * *}$ & $0.321^{* *}$ & 0.035 & -0.008 \\
\hline & $(4.15)$ & $(1.92)$ & $(2.76)$ & $(2.21)$ & $(0.30)$ & $(-0.09)$ \\
\hline \multirow{2}{*}{ 5-Factor Alpha } & $1.474^{* * *}$ & 0.310 & $0.408^{* *}$ & $0.334^{* *}$ & 0.034 & -0.009 \\
\hline & $(3.64)$ & $(1.58)$ & $(2.56)$ & $(2.24)$ & $(0.28)$ & $(-0.10)$ \\
\hline \multicolumn{7}{|c|}{ Panel B: Equal-Weighted Transactions and Value-Weighted Portfolios (EW-MVW) } \\
\hline \multirow{2}{*}{ Avg. Return } & $0.832^{* *}$ & $0.270^{* *}$ & $0.258^{* *}$ & $0.210^{* *}$ & 0.118 & 0.024 \\
\hline & $(2.50)$ & $(2.15)$ & $(2.45)$ & $(2.13)$ & $(1.34)$ & $(0.35)$ \\
\hline \multirow[t]{2}{*}{ CAPM Alpha } & $0.860^{* * *}$ & $0.294^{* *}$ & $0.282^{* * *}$ & $0.232^{* *}$ & 0.139 & 0.034 \\
\hline & $(2.64)$ & $(2.43)$ & $(2.88)$ & $(2.59)$ & $(1.60)$ & $(0.52)$ \\
\hline \multirow[t]{2}{*}{ FF Alpha } & $0.838^{* *}$ & $0.284^{* *}$ & $0.283^{* * *}$ & $0.230 * * *$ & 0.131 & 0.029 \\
\hline & $(2.63)$ & $(2.56)$ & $(3.15)$ & $(2.75)$ & $(1.65)$ & $(0.52)$ \\
\hline \multirow[t]{2}{*}{ Carhart Alpha } & $0.838^{* *}$ & $0.285^{* *}$ & $0.278^{* * *}$ & $0.220^{* *}$ & $0.120 *$ & 0.023 \\
\hline & $(2.60)$ & $(2.57)$ & $(2.96)$ & $(2.51)$ & $(1.70)$ & $(0.47)$ \\
\hline \multirow{2}{*}{ 5-Factor Alpha } & $0.876^{* *}$ & $0.286^{* *}$ & $0.273^{* * *}$ & $0.229^{* *}$ & 0.098 & -0.005 \\
\hline & $(2.35)$ & $(2.43)$ & $(2.84)$ & $(2.52)$ & $(1.47)$ & $(-0.12)$ \\
\hline \multicolumn{7}{|c|}{ Panel C: Value-Weighted Transactions and Equal-Weighted Portfolios (TW-MEW) } \\
\hline \multirow[t]{2}{*}{ Avg. Return } & $1.466^{* * *}$ & 0.310 & 0.317 & 0.221 & -0.028 & -0.052 \\
\hline & $(3.28)$ & (1.46) & (1.61) & $(1.28)$ & $(-0.19)$ & $(-0.42)$ \\
\hline \multirow[t]{2}{*}{ CAPM Alpha } & $1.593^{* * *}$ & $0.364^{* *}$ & $0.342^{* *}$ & 0.241 & -0.023 & -0.042 \\
\hline & $(4.04)$ & $(2.04)$ & $(2.06)$ & $(1.50)$ & $(-0.15)$ & $(-0.36)$ \\
\hline \multirow[t]{2}{*}{ FF Alpha } & $1.567^{* * *}$ & $0.355^{*}$ & $0.371^{* *}$ & $0.289^{* *}$ & 0.012 & -0.029 \\
\hline & $(3.99)$ & $(1.78)$ & & $(2.01)$ & $(0.10)$ & $(-0.27)$ \\
\hline \multirow[t]{2}{*}{ Carhart Alpha } & $1.565^{* * *}$ & $0.352^{*}$ & $0.361^{* *}$ & $0.281^{*}$ & 0.008 & -0.028 \\
\hline & $(3.92)$ & $(1.81)$ & $(2$. & $(1.92)$ & $(0.07)$ & $(-0.26)$ \\
\hline \multirow{2}{*}{ 5-Factor Alpha } & $1.513^{* * *}$ & 0.325 & $0.374^{* *}$ & $0.315^{* *}$ & 0.036 & -0.014 \\
\hline & $(3.48)$ & $(1.58)$ & $(2.44)$ & $(2.09)$ & $(0.30)$ & $(-0.13)$ \\
\hline \multicolumn{7}{|c|}{ Panel D: Value-Weighted Transactions and Value-Weighted Portfolios (TW-MVW) } \\
\hline \multirow[t]{2}{*}{ Avg. Return } & $0.826^{*}$ & 0.277 & 0.147 & 0.147 & 0.045 & -0.010 \\
\hline & $(1.77)$ & $(1.25)$ & $(0.72)$ & $(0.85)$ & $(0.34)$ & $(-0.10)$ \\
\hline \multirow[t]{2}{*}{ CAPM Alpha } & $0.862^{*}$ & 0.272 & 0.140 & 0.144 & 0.053 & -0.008 \\
\hline & $(1.95)$ & $(1.35)$ & $(0.75)$ & $(0.75)$ & $(0.35)$ & $(-0.08)$ \\
\hline FF Alpha & $0.900^{*}$ & 0.285 & 0.152 & 0.140 & 0.048 & -0.009 \\
\hline & (1.98) & $(1.42)$ & $(0.87)$ & $(0.73)$ & $(0.32)$ & $(-0.10)$ \\
\hline Carhart Alpha & $0.891^{*}$ & 0.280 & 0.145 & 0.132 & 0.044 & -0.011 \\
\hline & $(1.89)$ & $(1.42)$ & $(0.83)$ & $(0.71)$ & $(0.29)$ & $(-0.13)$ \\
\hline 5-Factor Alpha & $0.931^{*}$ & 0.268 & 0.115 & 0.098 & 0.011 & -0.044 \\
\hline & $(1.84)$ & $(1.21)$ & $(0.59)$ & $(0.48)$ & $(0.07)$ & $(-0.48)$ \\
\hline
\end{tabular}




\section{Table 2.6: Number of Transactions and Traders}

This table presents the breakdown of the transactions and traders on the basis of party and powerful committee membership.

\begin{tabular}{|c|c|c|}
\hline Party & Politicians & Transactions \\
\hline \multicolumn{3}{|c|}{ Panel A: Full Sample } \\
\hline Republicans & 232 & 39,538 \\
\hline Democrats & 168 & 22,373 \\
\hline
\end{tabular}

\begin{tabular}{|c|c|c|}
\hline \multicolumn{3}{|c|}{ Panel B: Powerful Politicians } \\
\hline Republicans & 163 & 27,892 \\
\hline Democrats & 127 & 18,438 \\
\hline \multicolumn{3}{|c|}{ Panel C: Non-Powerful Politicians } \\
\hline Republicans & 119 & 11,646 \\
\hline Democrats & 96 & 3,935 \\
\hline
\end{tabular}




\section{Table 2.7: Republicans}

This table presents average monthly raw and risk-adjusted returns (alphas) in percentages over 2004M012011M12 on the long/short (buy-minus-sell) portfolios based on the transactions by the members of the Republican Party involving only US common stocks listed on NYSE, AMEX, or NASDAQ. Transactions data is from Center for Responsive Politics, stock returns from CRSP, and five factors and risk-free rate from WRDS. Daily portfolio returns are calculated using four different weighting schemes under holding periods from 1 week to 12 months and compounded to monthly returns. Newey-West robust t-statistics (three lags) are in parenthesis. *,**,*** denote the 10, 5, and $1 \%$ significance levels.

\begin{tabular}{|c|c|c|c|c|c|c|}
\hline Holding Period (Months): & $1 / 4$ & 1 & 2 & 3 & 6 & 12 \\
\hline \multicolumn{7}{|c|}{ Panel A: Equal-Weighted Transactions and Equal-Weighted Portfolios (EW-MEW) } \\
\hline Avg. Return & $\begin{array}{c}2.242^{* * *} \\
(4.71)\end{array}$ & $\begin{array}{c}0.856^{* * *} \\
(3.09)\end{array}$ & $\begin{array}{c}0.744^{* * *} \\
(2.99)\end{array}$ & $\begin{array}{c}0.542^{* *} \\
(2.44)\end{array}$ & $\begin{array}{c}0.097 \\
(0.57)\end{array}$ & $\begin{array}{l}-0.046 \\
(-0.29)\end{array}$ \\
\hline CAPM Alpha & $\begin{array}{c}2.354^{* * *} \\
(5.29)\end{array}$ & $\begin{array}{c}0.941^{* * *} \\
(4.32)\end{array}$ & $\begin{array}{c}0.831^{* * *} \\
(4.26)\end{array}$ & $\begin{array}{c}0.630^{* * *} \\
(3.08)\end{array}$ & $\begin{array}{c}0.137 \\
(0.87)\end{array}$ & $\begin{array}{l}-0.019 \\
(-0.14)\end{array}$ \\
\hline FF Alpha & $\begin{array}{c}2.348^{* * *} \\
(5.32)\end{array}$ & $\begin{array}{c}0.910^{* * *} \\
(4.32)\end{array}$ & $\begin{array}{c}0.841^{* * *} \\
(4.31)\end{array}$ & $\begin{array}{c}0.657^{* * *} \\
(3.08)\end{array}$ & $\begin{array}{c}0.159 \\
(1.02)\end{array}$ & $\begin{array}{l}-0.009 \\
(-0.06)\end{array}$ \\
\hline Carhart Alpha & $\begin{array}{c}2.347^{* * *} \\
(5.27)\end{array}$ & $\begin{array}{c}0.906^{* * *} \\
(4.14)\end{array}$ & $\begin{array}{c}0.835^{* * *} \\
(4.20)\end{array}$ & $\begin{array}{c}0.648^{* * *} \\
(2.93)\end{array}$ & $\begin{array}{c}0.148 \\
(0.96)\end{array}$ & $\begin{array}{l}-0.017 \\
(-0.13)\end{array}$ \\
\hline 5-Factor Alpha & $\begin{array}{c}2.261^{* * *} \\
(4.69)\end{array}$ & $\begin{array}{c}0.865^{* * *} \\
(3.53)\end{array}$ & $\begin{array}{c}0.798^{* * *} \\
(3.66)\end{array}$ & $\begin{array}{c}0.687^{* * *} \\
(3.13)\end{array}$ & $\begin{array}{c}0.206 \\
(1.38)\end{array}$ & $\begin{array}{c}0.013 \\
(0.11)\end{array}$ \\
\hline \multicolumn{7}{|c|}{ Panel B: Equal-Weighted Transactions and Value-Weighted Portfolios (EW-MVW) } \\
\hline Avg. Return & $\begin{array}{c}1.428^{* * *} \\
(3.75)\end{array}$ & $\begin{array}{l}0.253 \\
(1.49)\end{array}$ & $\begin{array}{c}0.292^{* *} \\
(2.58)\end{array}$ & $\begin{array}{c}0.221^{* *} \\
(2.04)\end{array}$ & $\begin{array}{c}0.090 \\
(0.94)\end{array}$ & $\begin{array}{l}0.031 \\
(0.40)\end{array}$ \\
\hline CAPM Alpha & $\begin{array}{c}1.420^{* * *} \\
(3.67)\end{array}$ & $\begin{array}{c}0.260^{*} \\
(1.79)\end{array}$ & $\begin{array}{c}0.305^{* * *} \\
(3.64)\end{array}$ & $\begin{array}{c}0.240^{* * *} \\
(2.78)\end{array}$ & $\begin{array}{c}0.116 \\
(1.30)\end{array}$ & $\begin{array}{l}0.038 \\
(0.50)\end{array}$ \\
\hline FF Alpha & $\begin{array}{c}1.416^{* * *} \\
(3.78)\end{array}$ & $\begin{array}{c}0.245^{*} \\
(1.74)\end{array}$ & $\begin{array}{c}0.310^{* * *} \\
(3.80)\end{array}$ & $\begin{array}{c}0.238^{* * *} \\
(2.84)\end{array}$ & $\begin{array}{c}0.106 \\
(1.23)\end{array}$ & $\begin{array}{c}0.031 \\
(0.44)\end{array}$ \\
\hline Carhart Alpha & $\begin{array}{c}1.417^{* * *} \\
(3.77)\end{array}$ & $\begin{array}{c}0.244^{*} \\
(1.69)\end{array}$ & $\begin{array}{c}0.303^{* * *} \\
(3.26)\end{array}$ & $\begin{array}{c}0.229^{* *} \\
(2.38)\end{array}$ & $\begin{array}{l}0.095 \\
(1.18)\end{array}$ & $\begin{array}{l}0.023 \\
(0.38)\end{array}$ \\
\hline 5-Factor Alpha & $\begin{array}{c}1.449^{* * *} \\
(3.74)\end{array}$ & $\begin{array}{c}0.309^{* *} \\
(2.07)\end{array}$ & $\begin{array}{c}0.330^{* * *} \\
(3.19)\end{array}$ & $\begin{array}{c}0.268^{* * *} \\
(2.71)\end{array}$ & $\begin{array}{c}0.081 \\
(1.07)\end{array}$ & $\begin{array}{l}-0.005 \\
(-0.09)\end{array}$ \\
\hline \multicolumn{7}{|c|}{ Panel C: Value-Weighted Transactions and Equal-Weighted Portfolios (TW-MEW) } \\
\hline Avg. Return & $\begin{array}{c}2.203^{* * *} \\
(4.41)\end{array}$ & $\begin{array}{c}0.855^{* * *} \\
(3.05)\end{array}$ & $\begin{array}{c}0.712^{* * *} \\
(2.83)\end{array}$ & $\begin{array}{c}0.497 * * \\
(2.25)\end{array}$ & $\begin{array}{l}0.094 \\
(0.57)\end{array}$ & $\begin{array}{l}-0.063 \\
(-0.41)\end{array}$ \\
\hline CAPM Alpha & $\begin{array}{c}2.333^{* * *} \\
(5.12)\end{array}$ & $\begin{array}{c}0.939^{* * *} \\
(4.17)\end{array}$ & $\begin{array}{c}0.796^{* * *} \\
(3.97)\end{array}$ & $\begin{array}{c}0.580^{* * *} \\
(2.86)\end{array}$ & $\begin{array}{c}0.122 \\
(0.78)\end{array}$ & $\begin{array}{l}-0.045 \\
(-0.33)\end{array}$ \\
\hline FF Alpha & $\begin{array}{c}2.331^{* * *} \\
(5.13)\end{array}$ & $\begin{array}{c}0.913^{* * *} \\
(4.20)\end{array}$ & $\begin{array}{c}0.805^{* * *} \\
(4.06)\end{array}$ & $\begin{array}{c}0.605^{* * *} \\
(2.85)\end{array}$ & $\begin{array}{c}0.140 \\
(0.88)\end{array}$ & $\begin{array}{l}-0.036 \\
(-0.26)\end{array}$ \\
\hline Carhart Alpha & $\begin{array}{c}2.328^{* * *} \\
(5.03)\end{array}$ & $\begin{array}{c}0.909^{* * *} \\
(4.05)\end{array}$ & $\begin{array}{c}0.798^{* * *} \\
(3.94)\end{array}$ & $\begin{array}{c}0.596^{* * *} \\
(2.72)\end{array}$ & $\begin{array}{c}0.132 \\
(0.83)\end{array}$ & $\begin{array}{l}-0.041 \\
(-0.31)\end{array}$ \\
\hline 5-Factor Alpha & $\begin{array}{c}2.229 * * * \\
(4.49)\end{array}$ & $\begin{array}{c}0.871^{* * *} \\
(3.50)\end{array}$ & $\begin{array}{c}0.773^{* * *} \\
(3.50)\end{array}$ & $\begin{array}{c}0.643^{* * *} \\
(2.97)\end{array}$ & $\begin{array}{c}0.196 \\
(1.22)\end{array}$ & $\begin{array}{l}-0.003 \\
(-0.03)\end{array}$ \\
\hline \multicolumn{7}{|c|}{ Panel D: Value-Weighted Transactions and Value-Weighted Portfolios (TW-MVW) } \\
\hline Avg. Return & $\begin{array}{c}1.364^{* * *} \\
(2.80)\end{array}$ & $\begin{array}{l}0.340 \\
(1.30)\end{array}$ & $\begin{array}{l}0.305 \\
(1.23)\end{array}$ & $\begin{array}{l}0.119 \\
(0.52)\end{array}$ & $\begin{array}{l}-0.097 \\
(-0.51)\end{array}$ & $\begin{array}{l}-0.025 \\
(-0.19)\end{array}$ \\
\hline CAPM Alpha & $\begin{array}{c}1.381^{* * *} \\
(3.09)\end{array}$ & $\begin{array}{l}0.352 \\
(1.46)\end{array}$ & $\begin{array}{l}0.319 \\
(1.31)\end{array}$ & $\begin{array}{l}0.149 \\
(0.63)\end{array}$ & $\begin{array}{l}-0.064 \\
(-0.29)\end{array}$ & $\begin{array}{l}-0.018 \\
(-0.15)\end{array}$ \\
\hline FF Alpha & $\begin{array}{c}1.399 * * * \\
(2.94)\end{array}$ & $\begin{array}{l}0.357 \\
(1.52)\end{array}$ & $\begin{array}{l}0.329 \\
(1.39)\end{array}$ & $\begin{array}{l}0.164 \\
(0.71)\end{array}$ & $\begin{array}{l}-0.072 \\
(-0.34)\end{array}$ & $\begin{array}{l}-0.025 \\
(-0.21)\end{array}$ \\
\hline Carhart Alpha & $\begin{array}{c}1.386^{* * *} \\
(2.74)\end{array}$ & $\begin{array}{l}0.346 \\
(1.36)\end{array}$ & $\begin{array}{l}0.313 \\
(1.22)\end{array}$ & $\begin{array}{l}0.145 \\
(0.61)\end{array}$ & $\begin{array}{l}-0.085 \\
(-0.40)\end{array}$ & $\begin{array}{l}-0.032 \\
(-0.28)\end{array}$ \\
\hline 5-Factor Alpha & $\begin{array}{c}1.566^{* * *} \\
(2.99)\end{array}$ & $\begin{array}{l}0.425 \\
(1.56)\end{array}$ & $\begin{array}{l}0.299 \\
(1.15)\end{array}$ & $\begin{array}{l}0.108 \\
(0.47)\end{array}$ & $\begin{array}{l}-0.147 \\
(-0.72)\end{array}$ & $\begin{array}{l}-0.103 \\
(-0.97)\end{array}$ \\
\hline
\end{tabular}




\section{Table 2.8: Democrats}

This table presents average monthly raw and risk-adjusted returns (alphas) in percentages over 2004M012011M12 on the long/short (buy-minus-sell) portfolios based on the transactions by the members of the Democratic Party involving only US common stocks listed on NYSE, AMEX, or NASDAQ. Transactions data is from Center for Responsive Politics, stock returns from CRSP, and five factors and risk-free rate from WRDS. Daily portfolio returns are calculated using four different weighting schemes under holding periods from 1 week to 12 months and compounded to monthly returns. Newey-West robust t-statistics (three lags) are in parenthesis. ${ }^{*}, * *, * * *$ denote the 10,5 , and $1 \%$ significance levels.

\begin{tabular}{|c|c|c|c|c|c|c|}
\hline Holding Period (Months): & $1 / 4$ & 1 & 2 & 3 & 6 & 12 \\
\hline \multicolumn{7}{|c|}{ Panel A: Equal-Weighted Transactions and Equal-Weighted Portfolios (EW-MEW) } \\
\hline \multirow[t]{2}{*}{ Avg. Return } & 0.315 & -0.206 & -0.004 & -0.042 & -0.112 & -0.024 \\
\hline & $(0.49)$ & $(-0.64)$ & $(-0.01)$ & $(-0.15)$ & $(-0.47)$ & $(-0.13)$ \\
\hline \multirow[t]{2}{*}{ CAPM Alpha } & 0.382 & -0.172 & -0.036 & -0.079 & -0.125 & -0.015 \\
\hline & $(0.65)$ & $(-0.60)$ & $(-0.13)$ & $(-0.28)$ & $(-0.53)$ & $(-0.08)$ \\
\hline \multirow[t]{2}{*}{ FF Alpha } & 0.309 & -0.171 & 0.006 & -0.005 & -0.067 & 0.004 \\
\hline & $(0.55)$ & $(-0.58)$ & $(0.02)$ & $(-0.02)$ & $(-0.34)$ & $(0.02)$ \\
\hline \multirow[t]{2}{*}{ Carhart Alpha } & 0.321 & -0.170 & -0.006 & -0.013 & -0.070 & 0.009 \\
\hline & $(0.61)$ & $(-0.57)$ & $(-0.02)$ & $(-0.06)$ & $(-0.36)$ & $(0.06)$ \\
\hline \multirow[t]{2}{*}{ 5-Factor Alpha } & 0.471 & -0.201 & 0.015 & -0.031 & -0.133 & -0.029 \\
\hline & $(0.80)$ & $(-0.66)$ & $(0.06)$ & $(-0.14)$ & $(-0.68)$ & $(-0.18)$ \\
\hline \multicolumn{7}{|c|}{ Panel B: Equal-Weighted Transactions and Value-Weighted Portfolios (EW-MVW) } \\
\hline \multirow[t]{2}{*}{ Avg. Return } & 0.103 & 0.154 & 0.149 & 0.164 & $0.201^{*}$ & 0.052 \\
\hline & $(0.21)$ & $(0.76)$ & $(0.80)$ & $(1.19)$ & $(1.93)$ & $(0.61)$ \\
\hline \multirow[t]{2}{*}{ CAPM Alpha } & 0.122 & 0.184 & 0.170 & 0.177 & $0.203^{* *}$ & 0.060 \\
\hline & $(0.29)$ & (1.29) & $(1.04)$ & $(1.38)$ & $(2.16)$ & $(0.77)$ \\
\hline \multirow[t]{2}{*}{ FF Alpha } & 0.110 & 0.195 & 0.175 & 0.177 & $0.206^{* *}$ & 0.064 \\
\hline & $(0.26)$ & (1.36) & $(1.09)$ & $(1.33)$ & $(2.22)$ & $(0.86)$ \\
\hline \multirow[t]{2}{*}{ Carhart Alpha } & 0.118 & 0.198 & 0.174 & 0.165 & $0.197^{* *}$ & 0.060 \\
\hline & $(0.29)$ & (1.42) & $(1.09)$ & $(1.37)$ & $(2.39)$ & $(0.84)$ \\
\hline \multirow[t]{2}{*}{ 5-Factor Alpha } & 0.253 & 0.147 & 0.163 & 0.182 & $0.225^{* *}$ & 0.069 \\
\hline & $(0.54)$ & $(0.82)$ & $(0.93)$ & $(1.31)$ & $(2.60)$ & $(0.88)$ \\
\hline \multicolumn{7}{|c|}{ Panel C: Value-Weighted Transactions and Equal-Weighted Portfolios (TW-MEW) } \\
\hline \multirow[t]{2}{*}{ Avg. Return } & 0.438 & -0.207 & -0.067 & -0.063 & -0.173 & -0.045 \\
\hline & $(0.67)$ & $(-0.63)$ & $(-0.21)$ & $(-0.23)$ & $(-0.74)$ & $(-0.23)$ \\
\hline \multirow[t]{2}{*}{ CAPM Alpha } & 0.507 & -0.184 & -0.111 & -0.116 & -0.191 & -0.045 \\
\hline & $(0.80)$ & $(-0.63)$ & $(-0.40)$ & $(-0.43)$ & $(-0$ & $(-0.24)$ \\
\hline \multirow[t]{2}{*}{ FF Alpha } & 0.430 & -0.192 & -0.068 & -0.047 & -0.135 & -0.027 \\
\hline & $(0.71)$ & $(-0.64)$ & $(-0.27)$ & $(-0.21)$ & $(-0$ & $(-0.16)$ \\
\hline \multirow[t]{2}{*}{ Carhart Alpha } & 0.447 & -0.190 & -0.080 & -0.053 & -0.135 & -0.019 \\
\hline & $(0.80)$ & $(-0.62)$ & $(-0.33)$ & $(-0.24)$ & $(-0.71)$ & $(-0.12)$ \\
\hline \multirow[t]{2}{*}{ 5-Factor Alpha } & 0.591 & -0.200 & -0.038 & -0.043 & -0.148 & -0.035 \\
\hline & $(0.96)$ & $(-0.66)$ & $(-0.16)$ & $(-0.19)$ & $(-0.77)$ & $(-0.21)$ \\
\hline \multicolumn{7}{|c|}{ 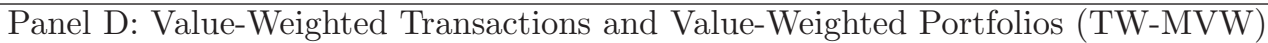 } \\
\hline \multirow[t]{2}{*}{ Avg. Return } & 0.817 & 0.039 & -0.076 & -0.011 & 0.191 & 0.004 \\
\hline & (1.19) & $(0.11)$ & $(-0.25)$ & $(-0.04)$ & (1 17 ) & $(0.03)$ \\
\hline \multirow[t]{2}{*}{ CAPM Alpha } & 0.820 & 0.033 & -0.103 & -0.038 & 0.186 & 0.007 \\
\hline & (1.14) & $(0.11)$ & $(-0.37)$ & $(-0.16)$ & $(1.22)$ & $(0.06)$ \\
\hline \multirow[t]{2}{*}{ FF Alpha } & 0.928 & 0.084 & -0.062 & -0.036 & 0.203 & 0.026 \\
\hline & $(1.30)$ & $(0.27)$ & $(-0.23)$ & $(-0.15)$ & $(1.30)$ & $(0.22)$ \\
\hline \multirow[t]{2}{*}{ Carhart Alpha } & 0.950 & 0.086 & -0.061 & -0.034 & 0.206 & 0.028 \\
\hline & $(1.44)$ & $(0.27)$ & $(-0.22)$ & $(-0.15)$ & & $(0.23)$ \\
\hline 5-Factor Alpha & 0.973 & 0.004 & -0.078 & -0.007 & 0.251 & 0.050 \\
\hline & $(1.32)$ & $(0.01)$ & $(-0.27)$ & $(-0.03)$ & (1.53) & $(0.41)$ \\
\hline
\end{tabular}




\section{Table 2.9: Powerful Republicans}

This table presents average monthly raw and risk-adjusted returns (alphas) in percentages over 2004M012011M12 on the buy-minus-sell portfolios from the transactions in NYSE/AMEX/NASDAQ common stocks by the members of the Republican Party serving on the top 20 powerful committees. Transactions data is from Center for Responsive Politics, stock returns from CRSP, and five factors and risk-free rate from WRDS. Daily portfolio returns are calculated using four different weighting schemes under holding periods from 1 week to 12 months and compounded to monthly returns. Newey-West robust t-statistics (three lags) are in parenthesis. ${ }^{*}, * *, * * *$ denote 10,5 , and $1 \%$ significance levels.

\begin{tabular}{|c|c|c|c|c|c|c|}
\hline Holding Period (Months): & $1 / 4$ & 1 & 2 & 3 & 6 & 12 \\
\hline \multicolumn{7}{|c|}{ 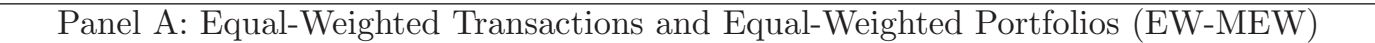 } \\
\hline Avg. Return & $\begin{array}{c}2.887^{* * * *} \\
(5.01)\end{array}$ & $\begin{array}{c}1.017^{* *} \\
(2.53)\end{array}$ & $\begin{array}{c}0.778^{* *} \\
(2.63)\end{array}$ & $\begin{array}{c}0.572^{* *} \\
(2.23)\end{array}$ & $\begin{array}{l}0.005 \\
(0.03)\end{array}$ & $\begin{array}{l}-0.290 \\
(-1.53)\end{array}$ \\
\hline CAPM Alpha & $\begin{array}{c}3.010^{* * *} \\
(5.46)\end{array}$ & $\begin{array}{c}1.163^{* * *} \\
(3.94)\end{array}$ & $\begin{array}{c}0.900^{* * *} \\
(3.81)\end{array}$ & $\begin{array}{c}0.694^{* * *} \\
(3.10)\end{array}$ & $\begin{array}{l}0.054 \\
(0.31)\end{array}$ & $\begin{array}{l}-0.261 \\
(-1.40)\end{array}$ \\
\hline FF Alpha & $\begin{array}{c}2.961^{* * *} \\
(5.33)\end{array}$ & $\begin{array}{c}1.116^{* * *} \\
(4.24)\end{array}$ & $\begin{array}{c}0.909^{* * *} \\
(4.01)\end{array}$ & $\begin{array}{c}0.706^{* * *} \\
(3.20)\end{array}$ & $\begin{array}{l}0.071 \\
(0.42)\end{array}$ & $\begin{array}{l}-0.252 \\
(-1.34)\end{array}$ \\
\hline Carhart Alpha & $\begin{array}{c}2.963^{* * *} \\
(5.35)\end{array}$ & $\begin{array}{c}1.114^{* * *} \\
(4.14)\end{array}$ & $\begin{array}{c}0.899^{* * *} \\
(3.85)\end{array}$ & $\begin{array}{c}0.693^{* * *} \\
(3.03)\end{array}$ & $\begin{array}{l}0.054 \\
(0.35)\end{array}$ & $\begin{array}{l}-0.260 \\
(-1.44)\end{array}$ \\
\hline 5-Factor Alpha & $\begin{array}{c}2.696^{* * *} \\
(4.62)\end{array}$ & $\begin{array}{c}0.932^{* * *} \\
(3.01)\end{array}$ & $\begin{array}{c}0.815^{* * *} \\
(3.17)\end{array}$ & $\begin{array}{c}0.669^{* * *} \\
(2.87)\end{array}$ & $\begin{array}{l}0.103 \\
(0.65)\end{array}$ & $\begin{array}{l}-0.250 \\
(-1.32)\end{array}$ \\
\hline \multicolumn{7}{|c|}{ Panel B: Equal-Weighted Transactions and Value-Weighted Portfolios (EW-MVW) } \\
\hline Avg. Return & $\begin{array}{c}2.295^{* * *} \\
(5.20)\end{array}$ & $\begin{array}{c}0.513^{* *} \\
(2.37)\end{array}$ & $\begin{array}{c}0.445^{* * *} \\
(3.07)\end{array}$ & $\begin{array}{c}0.297^{* *} \\
(2.30)\end{array}$ & $\begin{array}{l}0.098 \\
(0.87)\end{array}$ & $\begin{array}{l}-0.060 \\
(-0.50)\end{array}$ \\
\hline CAPM Alpha & $\begin{array}{c}2.280^{* * *} \\
(4.38)\end{array}$ & $\begin{array}{c}0.538^{* * *} \\
(2.87)\end{array}$ & $\begin{array}{c}0.458^{* * *} \\
(4.18)\end{array}$ & $\begin{array}{c}0.316^{* * *} \\
(3.01)\end{array}$ & $\begin{array}{l}0.124 \\
(1.17)\end{array}$ & $\begin{array}{l}-0.054 \\
(-0.43)\end{array}$ \\
\hline FF Alpha & $\begin{array}{c}2.271^{* * *} \\
(4.61)\end{array}$ & $\begin{array}{c}0.530^{* * *} \\
(3.08)\end{array}$ & $\begin{array}{c}0.458^{* * *} \\
(4.31)\end{array}$ & $\begin{array}{c}0.310^{* * *} \\
(3.06)\end{array}$ & $\begin{array}{l}0.108 \\
(1.03)\end{array}$ & $\begin{array}{l}-0.065 \\
(-0.54)\end{array}$ \\
\hline Carhart Alpha & $\begin{array}{c}2.276^{* * *} \\
(4.65)\end{array}$ & $\begin{array}{c}0.531^{* * *} \\
(3.07)\end{array}$ & $\begin{array}{c}0.451^{* * *} \\
(3.89)\end{array}$ & $\begin{array}{c}0.301^{* * * *} \\
(2.70)\end{array}$ & $\begin{array}{l}0.095 \\
(0.93)\end{array}$ & $\begin{array}{l}-0.074 \\
(-0.63)\end{array}$ \\
\hline 5-Factor Alpha & $\begin{array}{c}2.153^{* * *} \\
(4.48)\end{array}$ & $\begin{array}{c}0.443^{* *} \\
(2.57)\end{array}$ & $\begin{array}{c}0.441^{* * *} \\
(3.47)\end{array}$ & $\begin{array}{c}0.327^{* * *} * \\
(2.82)\end{array}$ & $\begin{array}{l}0.077 \\
(0.78)\end{array}$ & $\begin{array}{l}-0.136 \\
(-1.07)\end{array}$ \\
\hline \multicolumn{7}{|c|}{ Panel C: Value-Weighted Transactions and Equal-Weighted Portfolios (TW-MEW) } \\
\hline Avg. Return & $\begin{array}{c}2.868^{* * *} \\
(4.61)\end{array}$ & $\begin{array}{c}1.096^{* *} \\
(2.52)\end{array}$ & $\begin{array}{c}0.756^{* *} \\
(2.44)\end{array}$ & $\begin{array}{c}0.509^{*} \\
(1.93)\end{array}$ & $\begin{array}{l}-0.019 \\
(-0.10)\end{array}$ & $\begin{array}{l}-0.302 \\
(-1.64)\end{array}$ \\
\hline CAPM Alpha & $\begin{array}{c}3.016^{* * *} \\
(5.19)\end{array}$ & $\begin{array}{c}1.247^{* * *} \\
(3.82)\end{array}$ & $\begin{array}{c}0.881^{* * *} \\
(3.52)\end{array}$ & $\begin{array}{c}0.632^{* * *} \\
(2.74)\end{array}$ & $\begin{array}{l}0.019 \\
(0.12)\end{array}$ & $\begin{array}{l}-0.281 \\
(-1.47)\end{array}$ \\
\hline FF Alpha & $\begin{array}{c}2.967^{* * *} \\
(5.10)\end{array}$ & $\begin{array}{c}1.207^{* * *} \\
(4.24)\end{array}$ & $\begin{array}{c}0.889^{* * *} \\
(3.82)\end{array}$ & $\begin{array}{c}0.637^{* * *} \\
(2.78)\end{array}$ & $\begin{array}{l}0.032 \\
(0.19)\end{array}$ & $\begin{array}{l}-0.274 \\
(-1.42)\end{array}$ \\
\hline Carhart Alpha & $\begin{array}{c}2.965^{* * *} \\
(5.04)\end{array}$ & $\begin{array}{c}1.206^{* * *} \\
(4.19)\end{array}$ & $\begin{array}{c}0.879^{* * * *} \\
(3.64)\end{array}$ & $\begin{array}{c}0.623^{* * *} \\
(2.66)\end{array}$ & $\begin{array}{l}0.017 \\
(0.11)\end{array}$ & $\begin{array}{l}-0.279 \\
(-1.47)\end{array}$ \\
\hline 5-Factor Alpha & $\begin{array}{c}2.671^{* * *} \\
(4.37)\end{array}$ & $\begin{array}{c}0.989^{* * *} \\
(3.06)\end{array}$ & $\begin{array}{c}0.792^{* * *} \\
(3.01)\end{array}$ & $\begin{array}{c}0.610^{* *} \\
(2.56)\end{array}$ & $\begin{array}{l}0.075 \\
(0.45)\end{array}$ & $\begin{array}{l}-0.261 \\
(-1.31)\end{array}$ \\
\hline Panel D: Value-Weight & d Transact & ons and $\mathrm{V}_{\mathrm{c}}$ & ue-Weight & Portfolio & $(\mathrm{TW}-\mathrm{M}$ & (W) \\
\hline Avg. Return & $\begin{array}{c}2.084^{* * *} \\
(3.68)\end{array}$ & $\begin{array}{l}0.650^{*} \\
(1.94)\end{array}$ & $\begin{array}{l}0.415 \\
(1.43)\end{array}$ & $\begin{array}{l}0.159 \\
(0.64)\end{array}$ & $\begin{array}{l}-0.110 \\
(-0.52)\end{array}$ & $\begin{array}{l}-0.056 \\
(-0.34)\end{array}$ \\
\hline CAPM Alpha & $\begin{array}{c}2.082^{* * *} \\
(3.20)\end{array}$ & $\begin{array}{c}0.679 * * \\
(2.17)\end{array}$ & $\begin{array}{l}0.430 \\
(1.55)\end{array}$ & $\begin{array}{l}0.192 \\
(0.74)\end{array}$ & $\begin{array}{l}-0.069 \\
(-0.30)\end{array}$ & $\begin{array}{l}-0.046 \\
(-0.31)\end{array}$ \\
\hline FF Alpha & $\begin{array}{c}2.074^{* * *} \\
(3.22)\end{array}$ & $\begin{array}{c}0.704^{* *} \\
(2.56)\end{array}$ & $\begin{array}{c}0.445^{*} \\
(1.69)\end{array}$ & $\begin{array}{l}0.211 \\
(0.84)\end{array}$ & $\begin{array}{l}-0.085 \\
(-0.36)\end{array}$ & $\begin{array}{l}-0.056 \\
(-0.37)\end{array}$ \\
\hline Carhart Alpha & $\begin{array}{c}2.061^{* * *} \\
(3.05)\end{array}$ & $\begin{array}{c}0.692^{* *} \\
(2.29)\end{array}$ & $\begin{array}{l}0.427 \\
(1.48)\end{array}$ & $\begin{array}{l}0.189 \\
(0.72)\end{array}$ & $\begin{array}{l}-0.099 \\
(-0.43)\end{array}$ & $\begin{array}{l}-0.064 \\
(-0.43)\end{array}$ \\
\hline 5-Factor Alpha & $\begin{array}{c}2.165^{* * *} \\
(3.08)\end{array}$ & $\begin{array}{c}0.607^{* *} \\
(2.16)\end{array}$ & $\begin{array}{l}0.390 \\
(1.36)\end{array}$ & $\begin{array}{l}0.148 \\
(0.58)\end{array}$ & $\begin{array}{l}-0.159 \\
(-0.70)\end{array}$ & $\begin{array}{l}-0.162 \\
(-1.10)\end{array}$ \\
\hline
\end{tabular}




\section{Table 2.10: Powerful Democrats}

This table presents average monthly raw and risk-adjusted returns (alphas) in percentages over 2004M012011M12 on the buy-minus-sell portfolios from the transactions in NYSE/AMEX/NASDAQ common stocks by the members of the Democratic Party serving on the top 20 powerful committees. Transactions data is from Center for Responsive Politics, stock returns from CRSP, and five factors and risk-free rate from WRDS. Daily portfolio returns are calculated using four different weighting schemes under holding periods from 1 week to 12 months and compounded to monthly returns. Newey-West robust t-statistics (three lags) are in parenthesis.*, ${ }^{* *}, * * *$ denote 10,5 , and $1 \%$ significance levels.

\begin{tabular}{|c|c|c|c|c|c|c|}
\hline Holding Period (Months): & $1 / 4$ & 1 & 2 & 3 & 6 & 12 \\
\hline \multicolumn{7}{|c|}{ 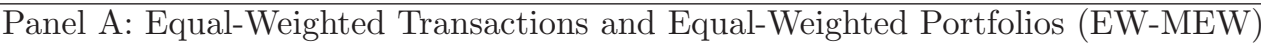 } \\
\hline \multirow[t]{2}{*}{ Avg. Return } & 0.617 & -0.203 & -0.144 & -0.092 & -0.057 & -0.039 \\
\hline & $(0.92)$ & $(-0.52)$ & $(-0.39)$ & $(-0.31)$ & $(-0.21)$ & $(-0.17)$ \\
\hline \multirow[t]{2}{*}{ CAPM Alpha } & 0.659 & -0.176 & -0.179 & -0.149 & -0.094 & -0.043 \\
\hline & $(1.08)$ & $(-0.51)$ & $(-0.62)$ & $(-0.58)$ & $(-0.39)$ & $(-0.21)$ \\
\hline \multirow[t]{2}{*}{ FF Alpha } & 0.625 & -0.165 & -0.118 & -0.068 & -0.018 & -0.018 \\
\hline & $(1.03)$ & $(-0.46)$ & $(-0.41)$ & $(-0.29)$ & $(-0.09)$ & $(-0.09)$ \\
\hline \multirow[t]{2}{*}{ Carhart Alpha } & 0.640 & -0.164 & -0.131 & -0.076 & -0.014 & -0.011 \\
\hline & $(1.13)$ & $(-0.45)$ & $(-0.48)$ & $(-0.34)$ & $(-0.07)$ & $(-0.06)$ \\
\hline \multirow[t]{2}{*}{ 5-Factor Alpha } & 0.769 & -0.092 & 0.000 & -0.007 & -0.037 & -0.052 \\
\hline & $(1.13)$ & $(-0.26)$ & $(0.00)$ & $(-0.03)$ & $(-0.16)$ & $(-0.27)$ \\
\hline \multicolumn{7}{|c|}{ Panel B: Equal-Weighted Transactions and Value-Weighted Portfolios (EW-MVW) } \\
\hline \multirow[t]{2}{*}{ Avg. Return } & 0.700 & 0.053 & 0.091 & 0.095 & 0.185 & 0.085 \\
\hline & $(1.25)$ & $(0.24)$ & $(0.46)$ & $(0.59)$ & $(1.48)$ & $(0.81)$ \\
\hline \multirow[t]{2}{*}{ CAPM Alpha } & 0.696 & 0.090 & 0.119 & 0.112 & $0.186^{*}$ & 0.096 \\
\hline & $(1.34)$ & $(0.57)$ & $(0.69)$ & $(0.73)$ & $(1.70)$ & $(1.01)$ \\
\hline \multirow[t]{2}{*}{ FF Alpha } & 0.691 & 0.102 & 0.145 & 0.121 & $0.203^{*}$ & 0.108 \\
\hline & $(1.33)$ & $(0.61)$ & $(0.80)$ & $(0.80)$ & $(1.85)$ & $(1.15)$ \\
\hline \multirow[t]{2}{*}{ Carhart Alpha } & 0.706 & 0.104 & 0.141 & 0.108 & $0.197^{*}$ & 0.105 \\
\hline & $(1.50)$ & $(0.62)$ & $(0.79)$ & $(0.80)$ & $(1.91)$ & $(1.16)$ \\
\hline \multirow[t]{2}{*}{ 5-Factor Alpha } & 0.876 & 0.025 & 0.133 & 0.123 & $0.217^{*}$ & 0.115 \\
\hline & $(1.48)$ & $(0.13)$ & $(0.69)$ & $(0.83)$ & $(1.90)$ & $(1.15)$ \\
\hline \multicolumn{7}{|c|}{ Panel C: Value-Weighted Transactions and Equal-Weighted Portfolios (TW-MEW) } \\
\hline \multirow[t]{2}{*}{ Avg. Return } & 0.828 & -0.158 & -0.192 & -0.112 & -0.083 & -0.042 \\
\hline & $(1.21)$ & $(-0.41)$ & $(-0.52)$ & $(-0.37)$ & $(-0.29)$ & $(-0.17)$ \\
\hline \multirow[t]{2}{*}{ CAPM Alpha } & 0.884 & -0.137 & -0.233 & -0.184 & -0.125 & -0.054 \\
\hline & $(1.35)$ & $(-0.42)$ & $(-0.82)$ & $(-0.71)$ & $(-0$ & $(-0.24)$ \\
\hline \multirow[t]{2}{*}{ FF Alpha } & 0.852 & -0.125 & -0.168 & -0.109 & -0.053 & -0.028 \\
\hline & $(1.29)$ & $(-0.37)$ & $(-0.60)$ & $(-0.45)$ & $(-0.24)$ & $(-0.14)$ \\
\hline \multirow[t]{2}{*}{ Carhart Alpha } & 0.873 & -0.121 & -0.179 & -0.114 & -0.044 & -0.020 \\
\hline & (1.46) & $(-0.35)$ & $(-0.68)$ & $(-0.48)$ & $(-0.20)$ & $(-0.10)$ \\
\hline \multirow[t]{2}{*}{ 5-Factor Alpha } & 0.981 & -0.072 & -0.057 & -0.027 & -0.022 & -0.048 \\
\hline & $(1.39)$ & $(-0.21)$ & $(-0.22)$ & $(-0.11)$ & $(-0.09)$ & $(-0.23)$ \\
\hline \multicolumn{7}{|c|}{ 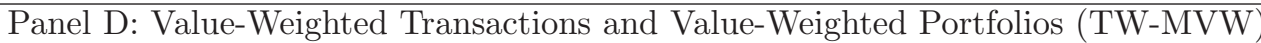 } \\
\hline \multirow[t]{2}{*}{ Avg. Return } & $1.223^{*}$ & 0.066 & -0.100 & -0.052 & 0.189 & 0.022 \\
\hline & $(1.67)$ & $(0.19)$ & $(-0.32)$ & $(-0.21)$ & $(0.99)$ & $(0.14)$ \\
\hline \multirow[t]{2}{*}{ CAPM Alpha } & 1.244 & 0.045 & -0.130 & -0.073 & 0.189 & 0.030 \\
\hline & $(1.42)$ & $(0.15)$ & $(-0.46)$ & $(-0.31)$ & $(0.99)$ & $(0.20)$ \\
\hline \multirow[t]{2}{*}{ FF Alpha } & 1.352 & 0.104 & -0.085 & -0.074 & 0.207 & 0.051 \\
\hline & $(1.60)$ & $(0.35)$ & $(-0.32)$ & $(-0.32)$ & (1.11) & $(0.35)$ \\
\hline \multirow[t]{2}{*}{ Carhart Alpha } & $1.388^{*}$ & 0.105 & -0.086 & -0.074 & 0.210 & 0.053 \\
\hline & & $(0.35)$ & $(-0.32)$ & $(-0.32)$ & $(1.11)$ & $(0.36)$ \\
\hline 5-Factor Alpha & $1.410^{*}$ & -0.020 & -0.108 & -0.031 & 0.275 & 0.097 \\
\hline & $(1.67)$ & $(-0.06)$ & $(-0.36)$ & $(-0.12)$ & $(1.33)$ & $(0.60)$ \\
\hline
\end{tabular}




\section{Table 2.11: Sophisticated Powerful Republicans}

This table presents average monthly raw and risk-adjusted returns (alphas) in percentages over 2004M012011M12 on buy-minus-sell portfolios from the transactions in NYSE/AMEX/NASDAQ common stocks by sophisticated (option trader/short-seller) Republicans on the top 20 powerful committees in Congress. Transactions data is from Center for Responsive Politics, stock returns from CRSP, and five factors and risk-free rate from WRDS. Daily portfolio returns are calculated using four different weighting schemes under holding periods from 1 week to 12 months and compounded to monthly returns. Newey-West robust t-statistics (three lags) are in parenthesis. ${ }^{*}, * *, * * *$ denote 10,5 , and $1 \%$ significance levels.

\begin{tabular}{|c|c|c|c|c|c|c|}
\hline Holding Period (Months): & $1 / 4$ & 1 & 2 & 3 & 6 & 12 \\
\hline \multicolumn{7}{|c|}{ Panel A: Equal-Weighted Transactions and Equal-Weighted Portfolios (EW-MEW) } \\
\hline \multirow[t]{2}{*}{ Avg. Return } & $1.650^{*}$ & 0.248 & 0.104 & 0.038 & 0.294 & -0.229 \\
\hline & $(1.73)$ & $(0.27)$ & $(0.14)$ & $(0.06)$ & $(0.55)$ & $(-0.61)$ \\
\hline \multirow[t]{2}{*}{ CAPM Alpha } & $1.693^{*}$ & 0.495 & 0.394 & 0.295 & 0.423 & -0.172 \\
\hline & $(1.81)$ & $(0.62)$ & $(0.72)$ & $(0.75)$ & $(0.89)$ & $(-0.56)$ \\
\hline \multirow[t]{2}{*}{ FF Alpha } & $1.767^{* *}$ & 0.550 & 0.457 & 0.304 & 0.424 & -0.187 \\
\hline & $(1.99)$ & $(0.77)$ & $(0.92)$ & $(0.86)$ & $(1.00)$ & $(-0.69)$ \\
\hline \multirow[t]{2}{*}{ Carhart Alpha } & $1.761^{*}$ & 0.531 & 0.433 & 0.272 & 0.389 & -0.204 \\
\hline & $(1.94)$ & $(0.71)$ & $(0.81)$ & $(0.74)$ & $(0.91)$ & $(-0.79)$ \\
\hline \multirow[t]{2}{*}{ 5-Factor Alpha } & $1.786^{*}$ & 0.398 & 0.404 & 0.242 & 0.417 & -0.208 \\
\hline & $(1.78)$ & $(0.49)$ & $(0.75)$ & $(0.65)$ & $(0.90)$ & $(-0.72)$ \\
\hline \multicolumn{7}{|c|}{ Panel B: Equal-Weighted Transactions and Value-Weighted Portfolios (EW-MVW) } \\
\hline \multirow[t]{2}{*}{ Avg. Return } & 1.278 & 0.574 & 0.191 & 0.172 & 0.056 & 0.025 \\
\hline & $(1.48)$ & $(1.19)$ & $(0.56)$ & $(0.62)$ & $(0.21)$ & $(0.10)$ \\
\hline \multirow[t]{2}{*}{ CAPM Alpha } & 1.127 & 0.551 & 0.168 & 0.151 & 0.037 & 0.002 \\
\hline & (1.45) & $(1.46)$ & $(0.63)$ & $(0.76)$ & $(0.18)$ & $(0.01)$ \\
\hline \multirow[t]{2}{*}{ FF Alpha } & 1.156 & 0.548 & 0.160 & 0.127 & -0.023 & -0.040 \\
\hline & $(1.52)$ & $(1.60)$ & $(0.61)$ & $(0.67)$ & $(-0.13)$ & $(-0.25)$ \\
\hline \multirow[t]{2}{*}{ Carhart Alpha } & 1.160 & 0.545 & 0.153 & 0.112 & -0.044 & -0.052 \\
\hline & (1.54) & $(1.57)$ & $(0.56)$ & $(0.55)$ & $(-0.24)$ & $(-0.34)$ \\
\hline \multirow[t]{2}{*}{ 5-Factor Alpha } & 1.396 & 0.622 & 0.313 & 0.284 & 0.039 & -0.035 \\
\hline & $(1.56)$ & $(1.56)$ & $(1.02)$ & $(1.20)$ & $(0.20)$ & $(-0.19)$ \\
\hline \multicolumn{7}{|c|}{ Panel C: Value-Weighted Transactions and Equal-Weighted Portfolios (TW-MEW) } \\
\hline \multirow{2}{*}{ Avg. Return } & 1.461 & 0.143 & -0.029 & -0.163 & 0.154 & -0.276 \\
\hline & $(1.49)$ & $(0.16)$ & $(-0.04)$ & $(-0.26)$ & $(0.28)$ & $(-0.79)$ \\
\hline \multirow[t]{2}{*}{ CAPM Alpha } & 1.517 & 0.407 & 0.281 & 0.095 & 0.269 & -0.234 \\
\hline & $(1.65)$ & $(0.51)$ & $(0.47)$ & $(0.22)$ & $(0.55)$ & $(-0.81)$ \\
\hline \multirow[t]{2}{*}{ FF Alpha } & $1.584^{*}$ & 0.480 & 0.350 & 0.112 & 0.267 & -0.261 \\
\hline & $(1.81)$ & $(0.69)$ & & $(0.31)$ & $(0.61)$ & $(-1.02)$ \\
\hline \multirow[t]{2}{*}{ Carhart Alpha } & $1.574^{*}$ & 0.457 & 0.327 & 0.079 & 0.234 & -0.270 \\
\hline & $(1.74)$ & $(0.62)$ & & $(0.21)$ & $(0.54)$ & $(-1.08)$ \\
\hline \multirow[t]{2}{*}{ 5-Factor Alpha } & 1.508 & 0.260 & 0.199 & 0.003 & 0.231 & -0.241 \\
\hline & $(1.50)$ & $(0.33)$ & $(0.36)$ & $(0.01)$ & $(0.49)$ & $(-0.90)$ \\
\hline \multicolumn{7}{|c|}{ Panel D: Value-Weighted Transactions and Value-Weighted Portfolios (TW-MVW) } \\
\hline \multirow[t]{2}{*}{ Avg. Return } & $1.893^{* *}$ & 0.871 & 0.252 & -0.086 & -0.256 & -0.232 \\
\hline & $(2.19)$ & $(1.51)$ & $(0.56)$ & $(-0.22)$ & $(-0.75)$ & $(-0.80)$ \\
\hline \multirow[t]{2}{*}{ CAPM Alpha } & $1.820^{* *}$ & 0.925 & 0.295 & -0.035 & -0.228 & -0.230 \\
\hline & $(2.37)$ & (1.61) & $(0.90)$ & $(-0.12)$ & $(-0.79)$ & $(-1.06)$ \\
\hline \multirow[t]{2}{*}{ FF Alpha } & $1.855^{* *}$ & $0.947^{*}$ & 0.304 & -0.021 & -0.259 & -0.245 \\
\hline & $(2.42)$ & $(1.90)$ & (1.01) & $(-0.08)$ & $(-0.93)$ & $(-1.22)$ \\
\hline \multirow[t]{2}{*}{ Carhart Alpha } & $1.845^{* *}$ & $0.922^{*}$ & 0.275 & -0.064 & -0.285 & -0.259 \\
\hline & $(2.32)$ & $(1.72)$ & $(0.79)$ & $(-0.23)$ & $(-1.04)$ & $(-1.38)$ \\
\hline 5-Factor Alpha & $1.993^{* *}$ & $0.860^{*}$ & 0.372 & 0.031 & -0.233 & -0.287 \\
\hline & $(2.26)$ & $(1.71)$ & $(1.00)$ & $(0.10)$ & $(-0.83)$ & $(-1.43)$ \\
\hline
\end{tabular}




\section{Table 2.12: Unsophisticated Powerful Republicans}

This table presents average monthly raw and risk-adjusted returns (alphas) in percentages over 2004M012011M12 on buy-minus-sell portfolios from the transactions in NYSE/AMEX/NASDAQ common stocks by unsophisticated (not option trader/short-seller) Republicans on the top 20 powerful committees in Congress. Transactions data is from Center for Responsive Politics, stock returns from CRSP, and five factors and risk-free rate from WRDS. Daily portfolio returns are calculated using four different weighting schemes under holding periods from 1 week to 12 months and compounded to monthly returns. NeweyWest t-statistics (three lags) are in parenthesis. ${ }^{*}, * *, * * *$ denote 10,5 , and $1 \%$ significance levels.

\begin{tabular}{|c|c|c|c|c|c|c|}
\hline \multirow{2}{*}{$\begin{array}{l}\text { Holding Period (Months): } \\
\text { Panel A: Equal-Weighte }\end{array}$} & $1 / 4$ & 1 & 2 & 3 & 6 & 12 \\
\hline & $\mathrm{d}$ Transact & nns and $\mathrm{Ec}$ & ual-Weight & d Portfolic & (EW-M & $\mathrm{EW}$ \\
\hline Avg. Return & $\begin{array}{c}3.332^{* * *} \\
(4.01)\end{array}$ & $\begin{array}{c}1.367^{* * *} \\
(2.86)\end{array}$ & $\begin{array}{c}1.035^{* * *} \\
(3.36)\end{array}$ & $\begin{array}{c}0.718^{* * *} \\
(2.83)\end{array}$ & $\begin{array}{l}-0.084 \\
(-0.49)\end{array}$ & $\begin{array}{l}-0.207 \\
(-1.20)\end{array}$ \\
\hline CAPM Alpha & $\begin{array}{l}3.430^{* * *} \\
(5.07)\end{array}$ & $\begin{array}{c}1.475^{* * *} \\
(3.55)\end{array}$ & $\begin{array}{c}1.111^{* * *} \\
(4.09)\end{array}$ & $\begin{array}{c}0.804^{* * *} \\
(3.09)\end{array}$ & $\begin{array}{l}-0.059 \\
(-0.36)\end{array}$ & $\begin{array}{l}-0.185 \\
(-1.30)\end{array}$ \\
\hline FF Alpha & $\begin{array}{c}3.304^{* * *} \\
(4.59)\end{array}$ & $\begin{array}{c}1.387^{* * *} \\
(3.67)\end{array}$ & $\begin{array}{c}1.101^{* * *} \\
(4.12)\end{array}$ & $\begin{array}{c}0.822^{* * *} \\
(3.10)\end{array}$ & $\begin{array}{l}-0.045 \\
(-0.26)\end{array}$ & $\begin{array}{l}-0.170 \\
(-1.21)\end{array}$ \\
\hline Carhart Alpha & $\begin{array}{c}3.306^{* * *} \\
(4.61)\end{array}$ & $\begin{array}{c}1.394^{* * *} \\
(3.76)\end{array}$ & $\begin{array}{c}1.097^{* * *} \\
(4.07)\end{array}$ & $\begin{array}{c}0.818^{* * *} \\
(3.04)\end{array}$ & $\begin{array}{l}-0.056 \\
(-0.34)\end{array}$ & $\begin{array}{l}-0.178 \\
(-1.34)\end{array}$ \\
\hline 5-Factor Alpha & $\begin{array}{c}2.890^{* * *} \\
(3.18)\end{array}$ & $\begin{array}{c}1.191^{* * * *} \\
(2.74)\end{array}$ & $\begin{array}{c}1.027^{* * * *} \\
(3.39)\end{array}$ & $\begin{array}{c}0.800^{* * *} \\
(2.75)\end{array}$ & $\begin{array}{l}-0.006 \\
(-0.04)\end{array}$ & $\begin{array}{l}-0.129 \\
(-1.02)\end{array}$ \\
\hline \multicolumn{7}{|c|}{ Panel B: Equal-Weighted Transactions and Value-Weighted Portfolios (EW-MVW) } \\
\hline Avg. Return & $\begin{array}{c}3.860^{* * *} \\
(4.98)\end{array}$ & $\begin{array}{c}1.039^{* * *} \\
(3.26)\end{array}$ & $\begin{array}{c}0.706^{* * *} \\
(3.14)\end{array}$ & $\begin{array}{c}0.530^{* * *} \\
(2.79)\end{array}$ & $\begin{array}{l}0.167 \\
(1.17)\end{array}$ & $\begin{array}{l}-0.003 \\
(-0.03)\end{array}$ \\
\hline CAPM Alpha & $\begin{array}{c}3.936^{* * *} \\
(5.40)\end{array}$ & $\begin{array}{c}1.086^{* * *} \\
(4.22)\end{array}$ & $\begin{array}{c}0.739^{* * *} \\
(4.18)\end{array}$ & $\begin{array}{c}0.570^{* * *} \\
(3.62)\end{array}$ & $\begin{array}{l}0.213^{*} \\
(1.70)\end{array}$ & $\begin{array}{l}0.016 \\
(0.15)\end{array}$ \\
\hline FF Alpha & $\begin{array}{c}3.837^{* * *} \\
(5.69)\end{array}$ & $\begin{array}{c}1.052^{* * *} \\
(4.47)\end{array}$ & $\begin{array}{c}0.718^{* * *} \\
(4.25)\end{array}$ & $\begin{array}{c}0.548^{* * *} \\
(3.70)\end{array}$ & $\begin{array}{l}0.201 \\
(1.59)\end{array}$ & $\begin{array}{l}0.011 \\
(0.09)\end{array}$ \\
\hline Carhart Alpha & $\begin{array}{c}3.841^{* * *} \\
(5.71)\end{array}$ & $\begin{array}{c}1.054^{* * *} \\
(4.48)\end{array}$ & $\begin{array}{c}0.709 * * * \\
(4.21)\end{array}$ & $\begin{array}{c}0.541^{* * *} \\
(3.45)\end{array}$ & $\begin{array}{l}0.189 \\
(1.59)\end{array}$ & $\begin{array}{l}0.002 \\
(0.02)\end{array}$ \\
\hline 5-Factor Alpha & $\begin{array}{c}3.259^{* * *} * \\
(4.78)\end{array}$ & $\begin{array}{c}0.862^{* * * *} \\
(3.35)\end{array}$ & $\begin{array}{c}0.602^{* * *} \\
(3.22) \\
\end{array}$ & $\begin{array}{c}0.481^{* * * *} \\
(2.79)\end{array}$ & $\begin{array}{l}0.138 \\
(1.14)\end{array}$ & $\begin{array}{l}-0.024 \\
(-0.23)\end{array}$ \\
\hline \multicolumn{7}{|c|}{ Panel C: Value-Weighted Transactions and Equal-Weighted Portfolios (TW-MEW) } \\
\hline \multicolumn{7}{|c|}{$\begin{array}{lllllll}\text { Avg. Return } & 3.451^{* * *} & 1.459^{* * *} & 1.029^{* * *} & 0.669^{* *} & -0.057 & -0.209\end{array}$} \\
\hline CAPM Alpha & $\begin{array}{c}3.571^{* * * *} \\
(5.06)\end{array}$ & $\begin{array}{c}1.572^{* * * *} \\
(3.53)\end{array}$ & $\begin{array}{c}1.105^{* * *} \\
(3.90)\end{array}$ & $\begin{array}{c}0.757^{* * *} \\
(2.88)\end{array}$ & $\begin{array}{l}-0.041 \\
(-0.25)\end{array}$ & $\begin{array}{l}-0.196 \\
(-1.30)\end{array}$ \\
\hline FF Alpha & $\begin{array}{c}3.435^{* * *} \\
(4.59)\end{array}$ & $\begin{array}{c}1.487^{* * *} \\
(3.72)\end{array}$ & $\begin{array}{c}1.093^{* * *} \\
(4.01)\end{array}$ & $\begin{array}{c}0.764^{* * *} \\
(2.86)\end{array}$ & $\begin{array}{l}-0.032 \\
(-0.18)\end{array}$ & $\begin{array}{l}-0.181 \\
(-1.23)\end{array}$ \\
\hline Carhart Alpha & $\begin{array}{c}3.437^{* * *} \\
(4.61)\end{array}$ & $\begin{array}{c}1.497^{* * *} \\
(3.88)\end{array}$ & $\begin{array}{c}1.090^{* * *} \\
(3.96)\end{array}$ & $\begin{array}{c}0.761^{* * * *} \\
(2.82)\end{array}$ & $\begin{array}{l}-0.040 \\
(-0.23)\end{array}$ & $\begin{array}{l}-0.187 \\
(-1.29)\end{array}$ \\
\hline 5-Factor Alpha & $\begin{array}{c}3.004^{* * *} \\
(3.20)\end{array}$ & $\begin{array}{c}1.262^{* * *} \\
(2.81)\end{array}$ & $\begin{array}{c}1.031^{* * *} \\
(3.37)\end{array}$ & $\begin{array}{c}0.765^{* * *} \\
(2.65)\end{array}$ & $\begin{array}{l}0.029 \\
(0.16)\end{array}$ & $\begin{array}{l}-0.131 \\
(-0.98)\end{array}$ \\
\hline \multicolumn{7}{|c|}{ Panel D: Value-Weighted Transactions and Value-Weighted Portfolios (TW-MVW) } \\
\hline Avg. Return & $\begin{array}{c}3.322^{* * *} \\
(4.83)\end{array}$ & $\begin{array}{c}1.095^{* * *} \\
(2.68)\end{array}$ & $\begin{array}{l}0.488 \\
(1.31)\end{array}$ & $\begin{array}{l}0.385 \\
(1.13)\end{array}$ & $\begin{array}{l}0.032 \\
(0.13)\end{array}$ & $\begin{array}{l}0.023 \\
(0.14)\end{array}$ \\
\hline CAPM Alpha & $\begin{array}{c}3.361^{* * * *} \\
(4.51)\end{array}$ & $\begin{array}{c}1.098^{* * * *} \\
(2.89)\end{array}$ & $\begin{array}{l}0.479 \\
(1.36)\end{array}$ & $\begin{array}{l}0.406 \\
(1.12)\end{array}$ & $\begin{array}{l}0.074 \\
(0.28)\end{array}$ & $\begin{array}{l}0.035 \\
(0.23)\end{array}$ \\
\hline FF Alpha & $\begin{array}{c}3.269^{* * *} \\
(4.74)\end{array}$ & $\begin{array}{c}1.051^{* * *} \\
(2.89)\end{array}$ & $\begin{array}{l}0.447 \\
(1.20)\end{array}$ & $\begin{array}{l}0.376 \\
(0.99)\end{array}$ & $\begin{array}{l}0.045 \\
(0.16)\end{array}$ & $\begin{array}{l}0.014 \\
(0.09)\end{array}$ \\
\hline Carhart Alpha & $\begin{array}{c}3.266^{* * *} \\
(4.69)\end{array}$ & $\begin{array}{c}1.063 * * * \\
(3.17)\end{array}$ & $\begin{array}{l}0.451 \\
(1.23)\end{array}$ & $\begin{array}{l}0.380 \\
(1.02)\end{array}$ & $\begin{array}{l}0.038 \\
(0.14)\end{array}$ & $\begin{array}{l}0.010 \\
(0.06)\end{array}$ \\
\hline 5-Factor Alpha & $\begin{array}{c}3.074^{* * *} * \\
(4.12)\end{array}$ & $\begin{array}{c}0.915^{* *} \\
(2.49)\end{array}$ & $\begin{array}{l}0.259 \\
(0.75)\end{array}$ & $\begin{array}{l}0.197 \\
(0.56)\end{array}$ & $\begin{array}{l}-0.064 \\
(-0.24)\end{array}$ & $\begin{array}{l}-0.048 \\
(-0.31)\end{array}$ \\
\hline
\end{tabular}




\section{Table 2.13: Unsophisticated Powerful Republicans: Tercile Analysis}

This table presents average monthly raw and risk-adjusted returns (alphas) in percentages over 2004M012011M12 on buy-minus-sell portfolios from the transactions in NYSE/AMEX/NASDAQ common stocks by unsophisticated (not option trader/short-seller) Republicans on the top 20 powerful committees in Congress. We first create three terciles of transactions based on the ratio of the transaction value (TV) to the net worth $(\mathrm{NW})$ of the politicians. We then construct calendar-time portfolios for each tercile of transactions. Transactions data is from Center for Responsive Politics, stock returns from CRSP, and five factors and risk-free rate from WRDS. Daily portfolio returns are calculated using four different weighting schemes under holding periods from 1 week to 12 months and compounded to monthly returns. Here we only report the results based on the EW-MEW weighting scheme (equal-weighted transactions and equal-weighted portfolios). Newey-West t-statistics (three lags) are in parenthesis. ${ }^{*},{ }^{* *},{ }^{* * *}$ denote 10,5 , and $1 \%$ significance levels.

\begin{tabular}{|c|c|c|c|c|c|c|}
\hline Holding Period (Months): & $1 / 4$ & 1 & 2 & 3 & 6 & 12 \\
\hline \multicolumn{7}{|c|}{ Panel A: Top Tercile } \\
\hline Avg. Return & $\begin{array}{l}3.370^{*} \\
(1.68)\end{array}$ & $\begin{array}{l}1.093 \\
(1.41)\end{array}$ & $\begin{array}{c}0.823^{* *} \\
(2.22)\end{array}$ & $\begin{array}{c}0.649^{*} \\
(1.83)\end{array}$ & $\begin{array}{l}-0.038 \\
(-0.15)\end{array}$ & $\begin{array}{l}-0.283 \\
(-1.00)\end{array}$ \\
\hline CAPM Alpha & $\begin{array}{c}3.216^{* *} \\
(2.10)\end{array}$ & $\begin{array}{l}1.113 \\
(1.62)\end{array}$ & $\begin{array}{c}0.860^{* *} \\
(2.32)\end{array}$ & $\begin{array}{l}0.681 \\
(1.66)\end{array}$ & $\begin{array}{l}-0.059 \\
(-0.21)\end{array}$ & $\begin{array}{l}-0.291 \\
(-1.00)\end{array}$ \\
\hline FF Alpha & $\begin{array}{l}2.880 \\
(1.60)\end{array}$ & $\begin{array}{l}0.975 \\
(1.38)\end{array}$ & $\begin{array}{c}0.824^{* *} \\
(2.25)\end{array}$ & $\begin{array}{l}0.655 \\
(1.64)\end{array}$ & $\begin{array}{l}-0.054 \\
(-0.19)\end{array}$ & $\begin{array}{l}-0.269 \\
(-0.97)\end{array}$ \\
\hline Carhart Alpha & $\begin{array}{l}2.887 \\
(1.60)\end{array}$ & $\begin{array}{l}0.984 \\
(1.40)\end{array}$ & $\begin{array}{c}0.833^{* *} \\
(2.31)\end{array}$ & $\begin{array}{c}0.662^{*} \\
(1.71)\end{array}$ & $\begin{array}{l}-0.045 \\
(-0.16)\end{array}$ & $\begin{array}{l}-0.267 \\
(-0.98)\end{array}$ \\
\hline 5-Factor Alpha & $\begin{array}{l}2.192 \\
(1.00) \\
\end{array}$ & $\begin{array}{l}0.726 \\
(0.85) \\
\end{array}$ & $\begin{array}{c}0.809^{* *} \\
(2.02) \\
\end{array}$ & $\begin{array}{c}0.731^{*} \\
(1.76) \\
\end{array}$ & $\begin{array}{l}0.088 \\
(0.32) \\
\end{array}$ & $\begin{array}{l}-0.189 \\
(-0.68) \\
\end{array}$ \\
\hline \multicolumn{7}{|c|}{ Panel B: Middle Tercile } \\
\hline Avg. Return & $\begin{array}{c}4.061^{* * *} \\
(3.17)\end{array}$ & $\begin{array}{c}1.572^{* *} \\
(2.25)\end{array}$ & $\begin{array}{c}1.665^{* * *} \\
(3.26)\end{array}$ & $\begin{array}{l}0.739 \\
(1.66)\end{array}$ & $\begin{array}{l}0.026 \\
(0.08)\end{array}$ & $\begin{array}{l}-0.248 \\
(-0.88)\end{array}$ \\
\hline CAPM Alpha & $\begin{array}{c}4.249^{* * *} \\
(4.04)\end{array}$ & $\begin{array}{c}1.678^{* * *} \\
(2.86)\end{array}$ & $\begin{array}{c}1.733^{* * *} \\
(3.86)\end{array}$ & $\begin{array}{c}0.812^{*} \\
(1.98)\end{array}$ & $\begin{array}{l}0.073 \\
(0.23)\end{array}$ & $\begin{array}{l}-0.212 \\
(-0.71)\end{array}$ \\
\hline FF Alpha & $\begin{array}{c}4.222^{* * *} \\
(4.42)\end{array}$ & $\begin{array}{c}1.603^{* * *} \\
(3.22)\end{array}$ & $\begin{array}{c}1.718^{* * *} \\
(3.89)\end{array}$ & $\begin{array}{c}0.828^{* *} \\
(2.07)\end{array}$ & $\begin{array}{l}0.057 \\
(0.19)\end{array}$ & $\begin{array}{l}-0.214 \\
(-0.72)\end{array}$ \\
\hline Carhart Alpha & $\begin{array}{c}4.228^{* * *} \\
(4.62)\end{array}$ & $\begin{array}{c}1.602^{* * *} \\
(3.18)\end{array}$ & $\begin{array}{c}1.706^{* * *} \\
(3.82)\end{array}$ & $\begin{array}{c}0.807^{* *} \\
(2.13)\end{array}$ & $\begin{array}{l}0.042 \\
(0.14)\end{array}$ & $\begin{array}{l}-0.218 \\
(-0.75)\end{array}$ \\
\hline 5-Factor Alpha & $\begin{array}{c}3.577^{* * *} \\
(4.24)\end{array}$ & $\begin{array}{c}1.385^{* * *} \\
(3.24) \\
\end{array}$ & $\begin{array}{c}1.525^{* * *} \\
(3.60)\end{array}$ & $\begin{array}{c}0.656^{*} \\
(1.76) \\
\end{array}$ & $\begin{array}{l}-0.035 \\
(-0.12)\end{array}$ & $\begin{array}{l}-0.295 \\
(-1.03)\end{array}$ \\
\hline \multicolumn{7}{|c|}{ Panel C: Bottom Tercile } \\
\hline Avg. Return & $\begin{array}{l}2.640 \\
(1.59)\end{array}$ & $\begin{array}{l}0.421 \\
(0.56)\end{array}$ & $\begin{array}{l}0.587 \\
(0.88)\end{array}$ & $\begin{array}{l}0.616 \\
(1.13)\end{array}$ & $\begin{array}{c}-0.884^{*} \\
(-1.91)\end{array}$ & $\begin{array}{l}-0.414 \\
(-1.30)\end{array}$ \\
\hline CAPM Alpha & $\begin{array}{l}2.591 \\
(1.47)\end{array}$ & $\begin{array}{l}0.446 \\
(0.79)\end{array}$ & $\begin{array}{l}0.709 \\
(1.36)\end{array}$ & $\begin{array}{l}0.686 \\
(1.43)\end{array}$ & $\begin{array}{c}-0.797^{*} \\
(-1.97)\end{array}$ & $\begin{array}{l}-0.383 \\
(-1.19)\end{array}$ \\
\hline FF Alpha & $\begin{array}{l}2.595 \\
(1.63)\end{array}$ & $\begin{array}{l}0.426 \\
(0.73)\end{array}$ & $\begin{array}{l}0.653 \\
(1.26)\end{array}$ & $\begin{array}{l}0.678 \\
(1.31)\end{array}$ & $\begin{array}{c}-0.795^{* *} \\
(-2.02)\end{array}$ & $\begin{array}{l}-0.406 \\
(-1.44)\end{array}$ \\
\hline Carhart Alpha & $\begin{array}{l}2.664^{*} \\
(1.71)\end{array}$ & $\begin{array}{l}0.435 \\
(0.74)\end{array}$ & $\begin{array}{l}0.651 \\
(1.25)\end{array}$ & $\begin{array}{l}0.686 \\
(1.38)\end{array}$ & $\begin{array}{c}-0.820^{* *} \\
(-2.18)\end{array}$ & $\begin{array}{l}-0.416 \\
(-1.52)\end{array}$ \\
\hline 5-Factor Alpha & $\begin{array}{l}2.637^{*} \\
(1.69)\end{array}$ & $\begin{array}{l}0.636 \\
(0.95)\end{array}$ & $\begin{array}{l}0.403 \\
(0.70)\end{array}$ & $\begin{array}{l}0.603 \\
(1.19)\end{array}$ & $\begin{array}{c}-0.933^{* *} \\
(-2.17)\end{array}$ & $\begin{array}{l}-0.433 \\
(-1.53)\end{array}$ \\
\hline
\end{tabular}




\section{Table 2.14: Powerful Republicans: Power and Pre/Post-Power Years}

This table presents both average monthly raw returns and risk-adjusted returns (alphas) over the 2004M01-2011M12 period on the long/short portfolios constructed based on the transactions by the members of the Republican party serving on the top 20 powerful committees. We identify 50 powerful members of the Republican Party, and measure their portfolio performance between the time that they were powerful (Panel A) and the time that they were not powerful (Panel B). We include only US common stocks listed on NYSE, AMEX, or NASDAQ. The transactions data is from Center for Responsive Politics, the stock returns from CRSP, and the five factors (market, size, value, momentum, and liquidity) along with the risk-free rate from WRDS. Daily portfolio returns are calculated based on four different weighting schemes summarized in Figure 1 under six different holding periods ranging from one week to 12 months and then compounded to monthly returns. In the table below, we only report the results based on the EW-MEW weighting scheme (equally weighted transactions \& equally weighted returns across traders). t-statistics are provided in parenthesis that are calculated with NeweyWest robust standard errors using three lags. ${ }^{*}, * *, * * *$ denote the 10,5 , and $1 \%$ significance levels, respectively. All returns are in percentages.

\begin{tabular}{lcccccc}
\hline Holding Period (Months): & $1 / 4$ & 1 & 2 & 3 & 6 & 12 \\
\hline \multirow{2}{c}{ Panel A: Power Years } & & & \\
\hline Avg. Return & $2.851^{* * *}$ & $0.990^{* *}$ & $0.675^{* *}$ & $0.604^{* *}$ & 0.126 & -0.160 \\
CAPM Alpha & $(4.22)$ & $(2.26)$ & $(2.12)$ & $(2.12)$ & $(0.50)$ & $(-0.66)$ \\
& $2.881^{* * *}$ & $1.081^{* * *}$ & $0.758^{* * *}$ & $0.690^{* * *}$ & 0.184 & -0.139 \\
FF Alpha & $(4.50)$ & $(2.91)$ & $(2.87)$ & $(2.71)$ & $(0.80)$ & $(-0.66)$ \\
& $2.813^{* * *}$ & $1.002^{* * *}$ & $0.769^{* * *}$ & $0.687^{* * *}$ & 0.183 & -0.144 \\
Carhart Alpha & $(4.56)$ & $(3.24)$ & $(3.10)$ & $(2.89)$ & $(0.83)$ & $(-0.63)$ \\
& $2.814^{* * *}$ & $1.005^{* * *}$ & $0.762^{* * *}$ & $0.672^{* * *}$ & 0.173 & -0.152 \\
5-Factor Alpha & $(4.53)$ & $(3.31)$ & $(3.03)$ & $(2.87)$ & $(0.79)$ & $(-0.68)$ \\
& $2.536^{* * *}$ & $0.780^{* *}$ & $0.579^{* *}$ & $0.446^{* *}$ & 0.044 & -0.324 \\
& $(4.11)$ & $(2.51)$ & $(2.42)$ & $(2.15)$ & $(0.19)$ & $(-1.49)$ \\
& & & & & & \\
\hline Avg. Return & Panel B: Pre-Power \& Post-Power Years & & \\
& -0.095 & -0.249 & -0.483 & -0.510 & $-1.046^{*}$ & 0.580 \\
CAPM Alpha & $(-0.08)$ & $(-0.23)$ & $(-0.51)$ & $(-0.71)$ & $(-1.80)$ & $(1.17)$ \\
& -0.261 & -0.393 & -0.774 & -0.557 & $-1.083^{*}$ & 0.585 \\
FF Alpha & $(-0.28)$ & $(-0.37)$ & $(-0.86)$ & $(-0.80)$ & $(-1.80)$ & $(1.00)$ \\
& -0.254 & -0.537 & -0.891 & -0.319 & $-1.071^{*}$ & 0.645 \\
Carhart Alpha & $(-0.32)$ & $(-0.57)$ & $(-1.00)$ & $(-0.45)$ & $(-1.87)$ & $(1.07)$ \\
& -0.289 & -0.560 & -0.752 & -0.335 & $-1.075^{*}$ & 0.655 \\
5-Factor Alpha & $(-0.35)$ & $(-0.59)$ & $(-0.89)$ & $(-0.47)$ & $(-1.88)$ & $(1.08)$ \\
& -0.466 & -0.288 & -0.690 & 0.007 & -0.923 & 0.780 \\
& $(-0.43)$ & $(-0.26)$ & $(-0.69)$ & $(0.01)$ & $(-1.58)$ & $(1.30)$ \\
\hline
\end{tabular}




\section{Table 2.15: Majority Control, Party Membership, and Portfolio Performance}

This table presents average monthly raw and risk-adjusted returns (alphas) in percentages on buyminus-sell portfolios from the transactions in NYSE/AMEX/NASDAQ common stocks by the powerful members of Congress. Transactions data is from Center for Responsive Politics, stock returns from CRSP, and five factors and risk-free rate from WRDS. Daily portfolio returns are calculated using four different weighting schemes under holding periods from 1 week to 12 months and compounded to monthly returns. We report the results based on equal-weighted transactions and portfolios (EW-MEW). NeweyWest t-statistics (three lags) are in parenthesis. ${ }^{*}, * *, * * *$ denote 10,5 , and $1 \%$ significance levels.

\begin{tabular}{|c|c|c|c|c|c|c|}
\hline Holding Period (Months): & $1 / 4$ & 1 & 2 & 3 & 6 & 12 \\
\hline \multicolumn{7}{|c|}{ Panel A: Republicans During Republican Majority Period (2004-2006) } \\
\hline \multirow[t]{2}{*}{ Avg. Return } & $2.116^{* * *}$ & $0.641^{* *}$ & $0.748^{* * *}$ & 0.170 & 0.424 & -0.188 \\
\hline & $(4.97)$ & $(2.47)$ & $(2.87)$ & $(0.58)$ & $(1.24)$ & $(-1.08)$ \\
\hline \multirow[t]{2}{*}{ CAPM Alpha } & $1.825^{* * *}$ & $0.651^{* * *}$ & $0.722^{* * *}$ & 0.170 & 0.498 & -0.219 \\
\hline & $(4.18)$ & $(3.58)$ & $(2.77)$ & $(0.60)$ & $(1.10)$ & $(-1.47)$ \\
\hline \multirow[t]{2}{*}{ FF Alpha } & $1.413^{* * *}$ & $0.461^{*}$ & $0.574^{* *}$ & -0.047 & 0.703 & -0.204 \\
\hline & (3.08) & $(1.93)$ & $(2.20)$ & $(-0.15)$ & $(1.02)$ & $(-1.45)$ \\
\hline \multirow[t]{2}{*}{ Carhart Alpha } & $1.457^{* * *}$ & $0.440^{*}$ & $0.526^{*}$ & -0.081 & 0.753 & -0.126 \\
\hline & (2.94) & $(1.84)$ & $(1.92)$ & $(-0.21)$ & $(1.08)$ & $(-0.86)$ \\
\hline \multirow[t]{2}{*}{ 5-Factor Alpha } & $1.458^{* * *}$ & $0.444^{*}$ & $0.547^{*}$ & -0.033 & 0.739 & -0.007 \\
\hline & $(2.99)$ & $(1.86)$ & $(1.96)$ & $(-0.10)$ & $(1.22)$ & $(-0.04)$ \\
\hline \multicolumn{7}{|c|}{ Panel B: Democrats During Republican Majority Period (2004-2006) } \\
\hline \multirow[t]{2}{*}{ Avg. Return } & 1.098 & 0.457 & 0.377 & -0.012 & 0.031 & -0.388 \\
\hline & $(1.36)$ & $(0.81)$ & $(0.87)$ & $(-0.03)$ & $(0.08)$ & $(-1.22)$ \\
\hline \multirow[t]{2}{*}{ CAPM Alpha } & 1.203 & 0.623 & 0.256 & -0.028 & 0.059 & -0.409 \\
\hline & $(1.67)$ & $(1.43)$ & $(0.70)$ & $(-0.08)$ & $(0.18)$ & $(-1.16)$ \\
\hline \multirow[t]{2}{*}{ FF Alpha } & $1.476^{*}$ & 0.830 & 0.557 & 0.006 & 0.170 & -0.507 \\
\hline & $(1.71)$ & $(1.36)$ & $(1.44)$ & $(0.02)$ & $(0.54)$ & $(-1.27)$ \\
\hline \multirow[t]{2}{*}{ Carhart Alpha } & $1.645^{*}$ & 0.787 & 0.523 & 0.090 & 0.194 & -0.321 \\
\hline & $(1.92)$ & $(1.34)$ & $(1.23)$ & $(0.28)$ & $(0.62)$ & $(-1.10)$ \\
\hline \multirow[t]{2}{*}{ 5-Factor Alpha } & $1.631^{* *}$ & 0.776 & 0.478 & 0.051 & 0.103 & -0.501 \\
\hline & $(2.05)$ & $(1.33)$ & $(1.02)$ & $(0.16)$ & $(0.26)$ & $(-1.25)$ \\
\hline \multicolumn{7}{|c|}{ Panel C: Republicans During Democratic Majority Period (2007-2010) } \\
\hline \multirow[t]{2}{*}{ Avg. Return } & $3.403^{* * *}$ & $1.296^{*}$ & $0.862^{*}$ & $0.740^{*}$ & -0.090 & -0.329 \\
\hline & $(3.62)$ & $(1.94)$ & $(1.81)$ & $(1.82)$ & $(-0.31)$ & $(-1.13)$ \\
\hline \multirow[t]{2}{*}{ CAPM Alpha } & $3.457^{* * *}$ & $1.354^{* * *}$ & $0.931^{* * *}$ & $0.809^{* *}$ & -0.061 & -0.319 \\
\hline & $(4.15)$ & $(3.09)$ & $(2.72)$ & $(2.56)$ & $(-0.24)$ & $(-1.09)$ \\
\hline \multirow[t]{2}{*}{ FF Alpha } & $3.156^{* * *}$ & $1.058^{* *}$ & $0.778^{* *}$ & $0.766^{* *}$ & -0.151 & -0.369 \\
\hline & $(3.68)$ & $(2.31)$ & $(2.19)$ & $(2.39)$ & $(-0.68)$ & $(-1.28)$ \\
\hline \multirow[t]{2}{*}{ Carhart Alpha } & $3.114^{* * *}$ & $1.062^{* *}$ & $0.796^{* *}$ & $0.787^{* *}$ & -0.107 & -0.336 \\
\hline & (3.71) & $(2.26)$ & $(2.17)$ & $(2.37)$ & $(-0.49)$ & $(-1.17)$ \\
\hline \multirow[t]{2}{*}{ 5-Factor Alpha } & $2.983^{* * *}$ & $0.975^{*}$ & $0.761^{*}$ & $0.769^{* *}$ & -0.085 & -0.336 \\
\hline & $(3.48)$ & $(1.99)$ & $(2.01)$ & $(2.31)$ & $(-0.40)$ & $(-1.16)$ \\
\hline \multicolumn{7}{|c|}{ Panel D: Democrats During Democratic Majority Period (2007-2010) } \\
\hline \multirow[t]{2}{*}{ Avg. Return } & 0.269 & -0.613 & -0.346 & 0.025 & -0.069 & 0.058 \\
\hline & $(0.27)$ & $(-1.15)$ & $(-0.63)$ & $(0.06)$ & $(-0.19)$ & $(0.19)$ \\
\hline \multirow[t]{2}{*}{ CAPM Alpha } & 0.285 & -0.605 & -0.361 & -0.007 & -0.090 & 0.056 \\
\hline & $(0.29)$ & $(-1.39)$ & $(-0.93)$ & $(-0.02)$ & $(-0.31)$ & $(0.20)$ \\
\hline \multirow[t]{2}{*}{ FF Alpha } & 0.240 & -0.671 & -0.363 & 0.012 & -0.117 & -0.005 \\
\hline & $(0.24)$ & $(-1.60)$ & $(-0.99)$ & $(0.04)$ & $(-0.47)$ & $(-0.02)$ \\
\hline \multirow[t]{2}{*}{ Carhart Alpha } & 0.140 & -0.663 & -0.317 & 0.032 & -0.133 & -0.035 \\
\hline & $(0.16)$ & $(-1.65)$ & $(-0.91)$ & $(0.12)$ & $(-0.52)$ & $(-0.14)$ \\
\hline 5-Factor Alpha & 0.263 & -0.561 & -0.214 & 0.092 & -0.129 & -0.031 \\
\hline & $(0.28)$ & $(-1.38)$ & $(-0.65)$ & $(0.35)$ & $(-0.50)$ & $(-0.12)$ \\
\hline
\end{tabular}




\section{Table 2.16: President's Party, Party Membership, and Portfolio Performance}

This table presents average monthly raw and risk-adjusted returns (alphas) in percentages on buyminus-sell portfolios from the transactions in NYSE/AMEX/NASDAQ common stocks by the powerful members of Congress. Transactions data is from Center for Responsive Politics, stock returns from CRSP, and five factors and risk-free rate from WRDS. Daily portfolio returns are calculated using four different weighting schemes under holding periods from 1 week to 12 months and compounded to monthly returns. We report the results based on equal-weighted transactions and portfolios (EW-MEW). NeweyWest t-statistics (three lags) are in parenthesis. ${ }^{*}, * *, * * *$ denote 10,5 , and $1 \%$ significance levels.

\begin{tabular}{|c|c|c|c|c|c|c|}
\hline Holding Period (Months): & $1 / 4$ & 1 & 2 & 3 & 6 & 12 \\
\hline \multicolumn{7}{|c|}{ Panel A: Republicans During Bush Presidency (2004-2008) } \\
\hline Avg. Return & $\begin{array}{c}2.842^{* * *} \\
(4.77)\end{array}$ & $\begin{array}{c}1.377^{* * *} \\
(2.80)\end{array}$ & $\begin{array}{c}0.852^{* * *} \\
(2.78)\end{array}$ & $\begin{array}{c}0.991^{* * *} \\
(2.81)\end{array}$ & $\begin{array}{l}-0.013 \\
(-0.06)\end{array}$ & $\begin{array}{l}-0.167 \\
(-0.86)\end{array}$ \\
\hline CAPM Alpha & $\begin{array}{c}2.715^{* * *} \\
(5.08)\end{array}$ & $\begin{array}{c}1.196^{* * *} \\
(3.87)\end{array}$ & $\begin{array}{c}0.766^{* * *} \\
(3.38)\end{array}$ & $\begin{array}{c}0.934^{* *} \\
(2.25)\end{array}$ & $\begin{array}{l}-0.027 \\
(-0.13)\end{array}$ & $\begin{array}{l}-0.159 \\
(-0.78)\end{array}$ \\
\hline FF Alpha & $\begin{array}{c}2.565^{* * *} \\
(4.24)\end{array}$ & $\begin{array}{c}1.171^{* * *} \\
(3.99)\end{array}$ & $\begin{array}{c}0.729^{* * *} \\
(3.23)\end{array}$ & $\begin{array}{c}0.915^{* *} \\
(2.08)\end{array}$ & $\begin{array}{l}-0.005 \\
(-0.02)\end{array}$ & $\begin{array}{l}-0.132 \\
(-0.63)\end{array}$ \\
\hline Carhart Alpha & $\begin{array}{c}2.449^{* * *} \\
(4.77)\end{array}$ & $\begin{array}{c}1.158^{* * *} \\
(3.51)\end{array}$ & $\begin{array}{c}0.663^{* * *} \\
(3.07)\end{array}$ & $\begin{array}{c}0.987^{* *} \\
(2.04)\end{array}$ & $\begin{array}{l}0.003 \\
(0.02)\end{array}$ & $\begin{array}{l}-0.133 \\
(-0.78)\end{array}$ \\
\hline 5-Factor Alpha & $\begin{array}{c}2.328^{* * * *} \\
(4.30)\end{array}$ & $\begin{array}{c}0.787^{* * * *} \\
(2.88)\end{array}$ & $\begin{array}{c}0.694^{* * *} \\
(3.52)\end{array}$ & $\begin{array}{c}1.133^{* *} \\
(2.17)\end{array}$ & $\begin{array}{l}0.079 \\
(0.50)\end{array}$ & $\begin{array}{l}-0.087 \\
(-0.52)\end{array}$ \\
\hline \multicolumn{7}{|c|}{ Panel B: Democrats During Bush Presidency (2004-2008) } \\
\hline Avg. Return & $\begin{array}{l}0.723 \\
(1.19)\end{array}$ & $\begin{array}{l}0.025 \\
(0.05)\end{array}$ & $\begin{array}{l}0.269 \\
(0.73)\end{array}$ & $\begin{array}{l}-0.092 \\
(-0.22)\end{array}$ & $\begin{array}{l}0.052 \\
(0.16)\end{array}$ & $\begin{array}{l}0.013 \\
(0.05)\end{array}$ \\
\hline CAPM Alpha & $\begin{array}{l}0.653 \\
(1.24)\end{array}$ & $\begin{array}{l}0.014 \\
(0.04)\end{array}$ & $\begin{array}{l}0.250 \\
(0.69)\end{array}$ & $\begin{array}{l}0.012 \\
(0.03)\end{array}$ & $\begin{array}{l}0.071 \\
(0.22)\end{array}$ & $\begin{array}{l}0.014 \\
(0.06)\end{array}$ \\
\hline FF Alpha & $\begin{array}{l}0.645 \\
(1.23)\end{array}$ & $\begin{array}{l}0.001 \\
(0.00)\end{array}$ & $\begin{array}{l}0.312 \\
(0.95)\end{array}$ & $\begin{array}{l}0.083 \\
(0.23)\end{array}$ & $\begin{array}{l}0.153 \\
(0.56)\end{array}$ & $\begin{array}{l}0.074 \\
(0.39)\end{array}$ \\
\hline Carhart Alpha & $\begin{array}{l}0.621 \\
(1.11)\end{array}$ & $\begin{array}{l}0.000 \\
(0.00)\end{array}$ & $\begin{array}{l}0.413 \\
(1.32)\end{array}$ & $\begin{array}{l}0.180 \\
(0.47)\end{array}$ & $\begin{array}{l}0.147 \\
(0.54)\end{array}$ & $\begin{array}{l}0.075 \\
(0.40)\end{array}$ \\
\hline 5-Factor Alpha & $\begin{array}{l}0.799 \\
(1.43)\end{array}$ & $\begin{array}{l}0.296 \\
(0.71)\end{array}$ & $\begin{array}{l}0.276 \\
(0.82)\end{array}$ & $\begin{array}{l}0.327 \\
(0.73)\end{array}$ & $\begin{array}{l}0.126 \\
(0.43)\end{array}$ & $\begin{array}{l}-0.024 \\
(-0.11)\end{array}$ \\
\hline \multicolumn{7}{|c|}{ Panel C: Republicans During Obama Presidency (2009-2010) } \\
\hline Avg. Return & $\begin{array}{c}2.835^{* *} \\
(2.47)\end{array}$ & $\begin{array}{l}0.999 \\
(0.91)\end{array}$ & $\begin{array}{l}1.024 \\
(0.99)\end{array}$ & $\begin{array}{l}0.871 \\
(0.93)\end{array}$ & $\begin{array}{l}0.574 \\
(0.68)\end{array}$ & $\begin{array}{l}0.007 \\
(0.01)\end{array}$ \\
\hline CAPM Alpha & $\begin{array}{l}3.406^{*} \\
(1.96)\end{array}$ & $\begin{array}{l}1.962^{*} \\
(1.73)\end{array}$ & $\begin{array}{l}2.138 \\
(1.66)\end{array}$ & $\begin{array}{l}1.902 \\
(1.58)\end{array}$ & $\begin{array}{l}1.513 \\
(1.49)\end{array}$ & $\begin{array}{l}0.560 \\
(0.62)\end{array}$ \\
\hline FF Alpha & $\begin{array}{l}2.252 \\
(1.40)\end{array}$ & $\begin{array}{l}0.740 \\
(0.89)\end{array}$ & $\begin{array}{l}1.053 \\
(1.15)\end{array}$ & $\begin{array}{l}0.960 \\
(1.16)\end{array}$ & $\begin{array}{l}0.504 \\
(0.78)\end{array}$ & $\begin{array}{l}-0.177 \\
(-0.32)\end{array}$ \\
\hline Carhart Alpha & $\begin{array}{l}2.075 \\
(1.33)\end{array}$ & $\begin{array}{l}0.582 \\
(0.69)\end{array}$ & $\begin{array}{l}0.991 \\
(1.10)\end{array}$ & $\begin{array}{l}0.939 \\
(1.21)\end{array}$ & $\begin{array}{l}0.484 \\
(0.78)\end{array}$ & $\begin{array}{l}-0.237 \\
(-0.42)\end{array}$ \\
\hline 5-Factor Alpha & $\begin{array}{l}1.891 \\
(1.09) \\
\end{array}$ & $\begin{array}{l}0.322 \\
(0.32) \\
\end{array}$ & $\begin{array}{l}0.719 \\
(0.73) \\
\end{array}$ & $\begin{array}{l}0.562 \\
(0.73) \\
\end{array}$ & $\begin{array}{l}0.266 \\
(0.45) \\
\end{array}$ & $\begin{array}{l}-0.298 \\
(-0.60) \\
\end{array}$ \\
\hline \multicolumn{7}{|c|}{ Panel D: Democrats During Obama Presidency (2009-2010) } \\
\hline Avg. Return & $\begin{array}{l}0.277 \\
(0.16)\end{array}$ & $\begin{array}{l}-1.036 \\
(-1.27)\end{array}$ & $\begin{array}{l}-0.649 \\
(-0.67)\end{array}$ & $\begin{array}{l}0.053 \\
(0.08)\end{array}$ & $\begin{array}{l}-0.280 \\
(-0.42)\end{array}$ & $\begin{array}{l}-0.393 \\
(-0.75)\end{array}$ \\
\hline CAPM Alpha & $\begin{array}{l}0.245 \\
(0.15)\end{array}$ & $\begin{array}{l}-1.034 \\
(-1.31)\end{array}$ & $\begin{array}{l}-0.944 \\
(-1.12)\end{array}$ & $\begin{array}{l}-0.391 \\
(-0.54)\end{array}$ & $\begin{array}{l}-0.610 \\
(-0.92)\end{array}$ & $\begin{array}{l}-0.585 \\
(-1.06)\end{array}$ \\
\hline FF Alpha & $\begin{array}{l}-0.292 \\
(-0.20)\end{array}$ & $\begin{array}{l}-1.368 \\
(-1.57)\end{array}$ & $\begin{array}{l}-1.261 \\
(-1.27)\end{array}$ & $\begin{array}{l}-0.532 \\
(-0.69)\end{array}$ & $\begin{array}{l}-0.648 \\
(-0.92)\end{array}$ & $\begin{array}{l}-0.578 \\
(-1.02)\end{array}$ \\
\hline Carhart Alpha & $\begin{array}{l}-0.905 \\
(-0.68)\end{array}$ & $\begin{array}{l}-1.401 \\
(-1.62)\end{array}$ & $\begin{array}{l}-0.913 \\
(-1.00)\end{array}$ & $\begin{array}{l}-0.354 \\
(-0.53)\end{array}$ & $\begin{array}{l}-0.534 \\
(-0.83)\end{array}$ & $\begin{array}{l}-0.512 \\
(-0.96)\end{array}$ \\
\hline 5-Factor Alpha & $\begin{array}{l}-0.443 \\
(-0.27)\end{array}$ & $\begin{array}{l}-1.378 \\
(-1.39)\end{array}$ & $\begin{array}{l}-0.489 \\
(-0.66)\end{array}$ & $\begin{array}{l}-0.116 \\
(-0.19)\end{array}$ & $\begin{array}{l}-0.446 \\
(-0.71)\end{array}$ & $\begin{array}{l}-0.494 \\
(-0.96)\end{array}$ \\
\hline
\end{tabular}




\section{Table 2.17: Connected and Non-Connected Portfolios}

This table presents average monthly raw and risk-adjusted returns (alphas) in percentages on buy-minussell portfolios from the transactions in NYSE/AMEX/NASDAQ common stocks by the unsophisticated (not an option trader/short-seller) members of of the Republican Party who serve on the most powerful 20 committees in Congress. We sort the trades by these politicians into two portfolios on the basis of whether politicians worked closely with a financial institution in the execution of these trades (connected and non-connected portfolios). Transactions data is from Center for Responsive Politics, stock returns from CRSP, and five factors and risk-free rate from WRDS. Daily portfolio returns are calculated using four different weighting schemes under holding periods from 1 week to 12 months and compounded to monthly returns. We report the results based on equal-weighted transactions and portfolios (EW-MEW). Newey-West t-statistics (three lags) are in parenthesis. ${ }^{*}, * *, * * *$ denote 10,5 , and $1 \%$ significance levels.

\begin{tabular}{lcccccc}
\hline Holding Period (Months): & $1 / 4$ & 1 & 2 & 3 & 6 & 12 \\
\hline & \multicolumn{2}{c}{ Panel A: Connected Portfolios } \\
\hline Avg. Return & $2.830^{*}$ & $1.376^{*}$ & 0.956 & 0.726 & -0.646 & -0.202 \\
& $(1.94)$ & $(1.84)$ & $(1.50)$ & $(1.41)$ & $(-1.26)$ & $(-0.45)$ \\
CAPM Alpha & $2.877^{*}$ & $1.481^{* * *}$ & $1.106^{* *}$ & $0.802^{*}$ & -0.582 & -0.190 \\
& $(1.98)$ & $(2.70)$ & $(2.09)$ & $(1.75)$ & $(-1.30)$ & $(-0.45)$ \\
FF Alpha & $2.723^{*}$ & $1.525^{* *}$ & $1.199^{* *}$ & $0.927^{* *}$ & -0.534 & -0.146 \\
& $(1.90)$ & $(2.63)$ & $(2.42)$ & $(2.10)$ & $(-1.30)$ & $(-0.36)$ \\
Carhart Alpha & $2.733^{*}$ & $1.508^{* * *}$ & $1.184^{* *}$ & $0.903^{*}$ & $-0.591^{*}$ & -0.166 \\
& $(1.94)$ & $(2.80)$ & $(2.34)$ & $(1.97)$ & $(-1.85)$ & $(-0.40)$ \\
5-Factor Alpha & $3.005^{* *}$ & $1.834^{* * *}$ & $1.201^{* *}$ & $0.917^{*}$ & -0.391 & 0.062 \\
& $(2.08)$ & $(3.33)$ & $(2.23)$ & $(1.89)$ & $(-1.11)$ & $(0.14)$ \\
\hline & Panel B: Non-Connected Portfolios & & \\
\hline Avg. Return & $3.010^{* * *}$ & $1.339^{* *}$ & $1.080^{* * *}$ & $0.720^{* * *}$ & 0.052 & -0.176 \\
& $(3.40)$ & $(2.43)$ & $(3.33)$ & $(2.66)$ & $(0.27)$ & $(-0.97)$ \\
CAPM Alpha & $3.077^{* * *}$ & $1.432^{* * *}$ & $1.144^{* * *}$ & $0.800^{* * *}$ & 0.082 & -0.159 \\
& $(4.16)$ & $(3.03)$ & $(3.96)$ & $(2.93)$ & $(0.43)$ & $(-1.00)$ \\
FF Alpha & $2.984^{* * *}$ & $1.334^{* * *}$ & $1.138^{* * *}$ & $0.813^{* * *}$ & 0.081 & -0.155 \\
& $(3.74)$ & $(3.05)$ & $(4.07)$ & $(2.98)$ & $(0.42)$ & $(-0.96)$ \\
Carhart Alpha & $2.991^{* * *}$ & $1.346^{* * *}$ & $1.138^{* * *}$ & $0.816^{* * *}$ & 0.077 & -0.158 \\
& $(3.76)$ & $(3.17)$ & $(4.06)$ & $(3.01)$ & $(0.40)$ & $(-1.00)$ \\
5-Factor Alpha & $2.455^{* *}$ & $1.037^{* *}$ & $1.017^{* * *}$ & $0.762^{* *}$ & 0.110 & -0.137 \\
& $(2.52)$ & $(2.04)$ & $(3.23)$ & $(2.54)$ & $(0.52)$ & $(-0.84)$ \\
\hline
\end{tabular}




\section{Chapter 3}

\section{Informed Trading through Family}

\section{Members: Evidence from}

\section{Congressional Trading}

\subsection{Introduction}

Say I find out some information, I tell my wife and she goes and trades on it, what's the difference?

Massachusetts Senator Scott Brown ${ }^{1}$

We hear often in the media about people passing on insider information (material and nonpublic) to friends or family members, and the Securities and Exchange Commission (SEC) pressing charges against them. For example, the SEC filed a lawsuit against an insider trading ring with 10 members for exploiting inside information on mergers. ${ }^{2}$ The key person in this insider trading ring was a Wells Fargo securities employee, and the tippees included friends, family members, and business colleagues. Besides such ordinary people and corporate insiders, the public also started hearing about another group of traders who allegedly exploit

\footnotetext{
${ }^{1}$ http://www.cnn.com/2012/07/19/politics/stock-act-loophole/index.html

${ }^{2}$ http://www.sec.gov/news/press/2012/2012-255.htm
} 
and pass on their private information for personal gains: members of Congress.

The members of the U.S. House, Senate and Executive Branch (politicians hereafter) have been under public pressure due to the allegations that they use insider information in their stock trades. This pressure played a pivotal role in the bipartisan efforts to pass the STOCK Act (Stop Trading on Congressional Knowledge Act), which was signed by the President into law on April 4, 2012. In this study, we investigate whether politicians share private information with their family members (spouses and dependent children), and thus enable them to trade on value-relevant information. The motivation for this quest comes from a CNN report that revealed a loophole in the implementation of the STOCK Act. ${ }^{3}$ The House Ethics committee excluded the coverage of the act to the family members of politicians while the Senate Ethics committee extended the coverage to both politicians and their family members. The House immediately closed the loophole after the CNN report.

Despite the public's interest to learn more about congressional trading, there are only a few academic studies addressing this issue. Ziobrowski et al. (2004; 2011) document that members of Congress' common stock investments outperform the market using data from the 90s and early 2000s. Karadas (2014c) presents evidence that politicians trade on macroeconomic information such that their aggregate trades predict future stock market returns during the 2004-2010 period. Using the data from the same period, Karadas (2014a) shows that firm-level congressional trading predicts future firm-level stock returns. Furthermore, there are short-term abnormal returns on congressional stock trades. Eggers and Hainmueller (2013b) find that politicians' investments in companies from their district or State generate $3 \%$ abnormal returns on the annual basis over the 2004-2008 period.

We first calculate the cumulative abnormal returns (CARs) on the politicians' and their

\footnotetext{
${ }^{3}$ http://www.cnn.com/2012/07/19/politics/stock-act-loophole/index.html
} 
family members' transactions. Next, we construct transactions-based calendar-time portfolios following Ziobrowski et al. (2004) and estimate the alphas (abnormal returns) on portfolios that long the buy transactions and short the sell transactions (long/short or buyminus-sell portfolios). We carry out the estimations of alphas separately for the politicians and their family members. The calendar-time portfolio approach is commonly applied in measuring the trading skills of retail traders (Odean, 1999; Seasholes and Zhu, 2010), and it allows us to measure the information content of the stock transactions in a dynamic fashion under different holding periods.

We are inspired by Berkman et al. (2013) who show that informed guardians exploit their private information by trading on behalf of babies and young children. We apply this idea to politicians and investigate whether politicians take advantage of their private information by trading through the accounts of their family members. Politicians can share information with their family members for a variety of reasons. First, they may think that there is less publicity associated with their families' trades than their own trades. Second, they may want to enhance their family members' well-being by providing them with value-relevant information. Third, they may lack the expertise in trading stocks and have their family members trade on their information. This paper is the first academic study that separately investigates the presence of informed trading by politicians and their family members. Our analysis documents that the transactions reported in the politicians and the spouses' accounts both contain value-relevant information capable of generating short-term abnormal returns, which suggests that politicians share information with their spouses.

The rest of the paper proceeds as follows. Section 2 introduces the hypotheses. Section 3 describes the data. Section 4 and 5 outline the empirical methodology and present the results. Section 6 provides a direct comparison between politicians and their spouses' portfolios. Section 7 examines the portfolios of the politicians' spouses based on the trading behavior 
of the politicians. Section 8 concludes the paper.

\subsection{Hypotheses}

We formulate four hypotheses to test the presence and extent of informed trading by politicians and their family members. We are interested in quantifying the extent of informed trading by politicians. Since the presence of abnormal returns is a strong indicator of informed trading, we hypothesize that politicians place value-relevant transactions generating abnormal returns in their portfolios:

- Hypothesis 1: Politicians trade on value-relevant information such that there are abnormal returns on their stock portfolios.

Our primary motivation in this study is to document whether members of Congress share their value-relevant private information with their family members. The incidence of such information sharing implies that the transactions placed by the family members also yield abnormal returns:

- Hypothesis 2: Politicians share some of their private information with their family members such that there are abnormal returns on the family members' portfolios.

Politicians and their family members trade via taxable and tax-deferred trading accounts such as IRAs, 401(k)s, and trusts. These tax-deferred accounts are mainly used for tax saving purposes, and they have long-term investment horizon. We hypothesize that the transactions the taxable accounts contain much more time-sensitive information than those in tax-deferred accounts. Therefore, we anticipate short-term (long-term) abnormal returns on the portfolios constructed from the transactions in taxable (tax-deferred) accounts:

- Hypothesis 3: The portfolios of the transactions in tax-deferred trading accounts have long-term abnormal returns whereas the portfolios of those in taxable trading account have short-term abnormal returns. 
Powerful politicians are exposed to more value-relevant information than non-powerful politicians. For example, Karadas (2014a) presents evidence that the transactions reported by the non-powerful members of Congress (politicians and family members combined) do not have any value-relevant information. We hypothesize that the more informed politicians are, the more informed their family members become. As a result, we anticipate higher abnormal returns on the portfolios of the powerful politicians' family members (powerful family members) compared to the portfolios of the other politicians' family members (nonpowerful family members):

- Hypothesis 4: Family members of powerful politicians are more informed than those of non-powerful politicians.

\subsection{Data}

The source of raw transactions data is the Center for Responsive Politics (www.opensecrets.org), which extracts these records from the annual financial disclosure reports (FDRs) filed by the members of Congress. Members of Congress are required to file these reports not only for their transactions but also for the transactions made by their spouses and dependent children (family members). The transactions data in this paper covers the 2004-2010 period and comes with the following information for each transaction: transaction date, the name of the asset involved, the name of the politician who filed the FDRs (filer), account type, and transaction amount. There are four different account types that the filers reported: politicians' own accounts (P), their spouses (S) and dependent children's (D) accounts, and joint accounts $(\mathrm{J})$. We follow the same procedures as in Karadas (2014a) to clean the data. At the end of the cleaning process, we are left with 61,998 transactions from 2671 unique stocks. These stocks are mostly split between NYSE and NASDAQ (49.76\%, 46.72\%, respectively) with only $3.52 \%$ of them listed on AMEX. 
Table 3.1 presents information on the types of the filers and the number of transactions each filer reported for each account type over the 20004-2010 sample period. We identified three different filer types among politicians such that Type I politicians only reported the trades for themselves, Type II politicians reported trades for themselves and their family members, and Type III politicians reported trades only for their family members. For example, there are 130 Type II politicians who reported 17,164 transactions for themselves. Some of these 130 politicians also reported transactions for the remaining account types $(\mathrm{S}$, D, and J): 21 of them reported 537 transactions for their dependent children, 94 of them reported 11, 635 transactions for their spouses, and finally 49 of them reported 3,176 joint transactions. Overall, members of Congress reported 34,180 transactions for themselves, 19,559 for their spouses, 2,600 for their dependent children, and 5,659 for the joint accounts that they have with their family members.

Table 3.2 shows the descriptive statistics of the transaction values for each account type. The mean transaction value by the spouses is more than twice as much the mean transaction value by the other account types. Furthermore, politicians and spouses both have substantially large transactions up to $\$ 50$ million whereas the highest transaction value is less than one tenth of this limit for the dependent children's and joint transactions.

\subsection{Event Analysis and Results}

The main tools for empirical analysis in the study are event analysis and transactions-based calendar-time portfolio approach. Both methods enable us to measure the returns on the common stock investments of politicians and their family members through time. We first present the results from the event analysis. 


\subsubsection{Setup}

We use the market-adjusted model as in Ziobrowski et al. (2004) in the calculation of abnormal returns by assuming a market beta of 1 for all stocks. We first calculate the cumulative abnormal returns (CARs) for each transaction from trading day 0 (transaction date) to trading day 252 :

$$
C A R_{j, T}=\sum_{t=0}^{T}\left(R_{j t}-R_{m t}\right)
$$

where $T$ goes from 0 to $252, R_{j t}$ is the return on transaction $j$ on day $t$, and $R_{m t}$ stands for the CRSP value-weighted market index return. Next, we average CARs across transactions on each trading day to obtain the average cumulative abnormal returns:

$$
\overline{C A R_{T}}=\sum_{j=1}^{J} w_{j, T} C A R_{j, T}
$$

where $J$ is the number of transactions in the buy or sell sample, and $w_{j, T}$ is the weight of transaction $j$ on trading day $T$. We calculate equal-weighted average cumulative abnormal returns such that $w_{j, T}$ equals $\frac{1}{J_{T}}$ where $J_{T}$ is the number of transactions on trading day $T$.

We re-group the joint transactions under politicians' transactions and combine the transactions by spouses and dependent children as the family transactions. As a result, we have 39,839 transactions (18,859 buy and 20,980 sell) in the politician sample and 22,159 transactions (11,926 buy and 10,233 sell) in the family sample. We use the event analysis mainly for the graphical representation of cumulative abnormal returns. We avoid drawing any inferences from the CARs because of the cross-sectional dependence issue. The standard event study approaches assume that cumulative abnormal returns are cross-sectionally independent. However, in our data set, we have event-clustering (transactions taking place on the same trading day) and overlapping event windows (the same stock could have been bought or sold within few days of each other). As a result, the standard test statistics are biased (Kothari and Warner, 2007). 


\subsubsection{Results}

As part of our research question, we are interested in the return differences between the buy and sell transactions. Thus, we calculate the difference between the CARs from the buy and sell transactions in the politician and family sample. Figure 1 shows this difference for the equal-weighted CARs in addition to the CARs on buy and sell transactions. The buy transactions of the family members outperform those of the politicians. Similarly, the sell transactions of the family members underperform those of the politicians. Nevertheless, the difference between the families' and politicians' performance is much larger when it comes to the buy transactions compared to the sell transactions. Overall, the transactions by the family members earn significantly higher returns than those by politicians with the difference exceeding five fold suggesting that the transaction by the family members contain more value-relevant information than those by the politicians.

\section{[Figure 1 About Here]}

\subsection{Transactions-Based Calendar-Time Portfolios}

Fama (1998) recommends the use of the calendar-time portfolio methodology in event studies because it eliminates the cross-sectional dependence between abnormal returns. Based on this recommendation, Ziobrowski et al. (2004; 2011) construct transactions-based calendartime portfolios assuming a one-year holding period. The assumption of a one-year holding period can be justified by the average holding period for retail investors (Seasholes and Zhu, 2010). We follow the methodology in Ziobrowski et al. (2004; 2011) and construct the calendar-time portfolios, but we allow the holding period to change from 1 week (5 trading days) to one year (252 trading days). Even though a one-year holding period could give us a better picture about the abnormal returns captured by politicians, shorter holding periods present us the opportunity to examine whether politicians and their family members 
are informed traders using time-sensitive information. Karadas (2013a) provides a richer discussion on the calendar-time portfolios and the issues of informed trading.

\subsubsection{Portfolio Construction}

The first step towards setting up the calendar-time portfolios is to calculate the daily returns on the portfolio on trading day $t$ by $R_{p o r t, t}=\frac{\sum_{j=1}^{J} c o m p_{j t} R_{j t}}{\sum_{j=1}^{J} c o m p_{j t}}$. The denominator sums the compounded value of each transaction at the beginning of trading day $t$, and the numerator sums the dollar returns on each transaction on trading day $t$.

We use four different weighting schemes in the calculation of daily returns. Figure 2 presents the chart of these weighting schemes. $E W-M E W$ assigns equal weights to all transactions and all traders. This weighting scheme neutralizes the importance of transaction amounts and the portfolio size by assuming a value of $\$ 1$ for all transactions and averaging trader-level returns equally on each trading day. $E W-M V W$ still assigns equal-weights to all transactions, but weight returns across traders by their portfolio size. Naturally, traders with larger portfolios get more weight. Since all transactions are assumed to be $\$ 1$, large portfolios can be acquired only by more intensive trading and better trading decisions. $T W-M E W$ uses the actual transaction values, but still neutralizes the importance of the portfolio size. Finally, $T W-M V W$ uses actual transaction amounts and weights trader-level returns by the portfolio size.

If a trader took a very large position in a particular transaction and faced losses, the returns based on $E W-M E W$ and $E W-M V W$ will not be sensitive to this particular trade because all transactions are assumed to be the same amount. On the other hand, the results based on $T W-M E W$ and $T W-M V W$ will be sensitive with the former being less affected due to equal weights assigned to all traders. If a trader with a very large portfolio size faces losses, only the results based on $E W-M V W$ and $T W-M V W$ will be sensitive. 


\section{[Figure 2 About Here]}

The second step in constructing the calendar-time portfolios is to compound the daily returns to get the monthly returns. As a result of these steps, we have monthly stock returns starting in January of 2004 and ending in December of 2010. We also have additional months of stock returns up to 12 months depending on the holding period assumption. For example, when the holding period is one year, the return series extend until December of 2011. We execute these two steps for buy and sell transactions separately. Our interest lies in the portfolio that longs the buy transactions and shorts the sell transactions. If a group of traders are informed, the returns on what they buy should exceed that on what they sell (Seasholes and Zhu, 2010). We measure the extent of informed trading based on the magnitude and statistical significance of alphas (abnormal returns) on this long/short (i.e., hedged, buy-minus-sell) portfolio.

\subsubsection{Alphas on the Long/Short Portfolios}

We measure the abnormal returns based on four different models using the CAPM as the baseline equation. We employ Fama-French three-factor, Carhart four-factor, and five factors models to add robustness to our results. The full model we estimate (five-factor model) is:

$$
r_{p, t}=\alpha_{i}+\beta_{i}\left(r_{m, t}-r_{f, t}\right)+s_{p} S M B_{t}+h_{p} H M L_{t}+m_{p} U M D_{t}+l_{p} L I Q U I D_{t}+\varepsilon_{p, t}
$$

where $r_{p, t}$ is the return on the long/short portfolio (buy-minus-sell) on the transactions in the politicians or family members sample. The first factor, $r_{m, t}-r_{f, t}$, is the excess returns on the CRSP value-weighted index. $S M B$ (small-minus-big) and $H M L$ (high-minus-low)

are the size and value factors described in Fama (1993). UMD (up-minus-down) captures 
the momentum in stock returns whereas LIQUID measures the liquidity risk (Pastor and Stambaugh, 2003). We are primarily interest in the sign, magnitude (economic significance), and statistical significance of the alphas in each model. A statistically and economically significant positive alpha implies that politicians or family members are informed traders and the extent of their informational advantage is non-negligible.

\subsubsection{Portfolio Performance of Four Different Account Types}

In the portfolio analysis, we separately measure the portfolio performance of each category of accounts: politicians, spouses, dependent children, and joint. The CAR analysis suggests that politicians share information with their family members. It then becomes interesting to reveal how this information is shared. Mainly, we are interested in finding out whether politicians take advantage of their value-relevant information trading through their spouses' or dependent children's accounts. We are also interested in revealing the information content of the joint transactions as they offer an interesting perspective into how politicians share information with their family members under the joint ownership of the accounts.

\section{[Table 3.3 About Here]}

\section{[Table 3.4 About Here]}

We present the results of our portfolio analysis in Tables 3.3, 3.4, 3.5, and 3.6. For politicians, the abnormal returns exceed $12 \%$ at the one-week holding period, but they disappear within two months of the transaction date. Furthermore, when we weight the portfolio returns across politicians by their portfolio size (panel D), the statistical significance

of the abnormal returns completely disappear. This finding suggests that there are some politicians in the sample with large transactions and hence large portfolios who suffered sizable losses. Overall, we have support for Hypothesis 1. 


\title{
[Table 3.5 About Here]
}

\author{
[Table 3.6 About Here]
}

The abnormal returns in the spouses' portfolios exceed $12 \%$, similarly to those in the politicians' portfolios, at the one-week holding period. Nevertheless, the abnormal returns persist up to one year. This finding suggests that the spouses' transactions contain less timesensitive information than the politicians' transactions. On the other hand, the dependent children's portfolios underperform the market while there is a marginal evidence of abnormal performance for the joint portfolios. Overall, these results suggest that politicians take advantage of their private information only through their spouses' accounts, and we have partial support for Hypothesis 2.

\subsubsection{Investments through Taxable versus Tax-Deferred Trading Accounts}

Members of Congress and their spouses take advantage of tax-deferred investment opportunities either through retirement accounts (IRA and 401(k)) or by setting up trusts. The total number of retirement transactions for politicians and their spouses are 2,910 and 1,716, respectively. On the other hand, the total number of trust transactions for politicians and their spouses are 3,157 and 3,341, respectively. We separately investigate the information content of the retirement and trust transactions since they serve different purposes. In particular, retirement income is for spouses and politicians themselves, but the trust income is for intergenerational wealth transfers. As we laid out in Hypothesis 3, we anticipate longterm abnormal returns in the trust and retirement portfolios. At this point of our analysis, 
we proxy the long-term investment horizon with one-year holding period. ${ }^{4}$

[Table 3.7 About Here]

[Table 3.8 About Here]

We show the results of the politicians' retirement and trust portfolios' analyses in Tables 3.7 and 3.8. Contrary to what we anticipated, there is no trace of abnormal performance in the retirement portfolio in long-term period. On the other hand, the trust portfolios underperform the market, and this underperformance persists from short-term to long-term. Once we exclude the retirement transactions from the politicians' portfolios, the abnormal returns slightly deteriorate and they disappear within two months of the transaction date. ${ }^{5}$ Once the trust transactions are excluded, the abnormal returns increase in magnitude, but still preserve their short-term nature as presented in Table 3.9.

\section{[Table 3.9 About Here]}

Similar to politicians, the spouses' retirement portfolios do not have any abnormal returns in the short and long-term horizons. However, their trust portfolios have abnormal returns at the six-month holding period. Once we remove the trust and retirement transactions from the spouses' portfolios, the abnormal returns deteriorate and persist only until six months, which is consistent with what we anticipated in Hypothesis 3. In the end, we have only partial support for Hypothesis 3 due to lack of long-term abnormal returns in the trust and retirement portfolios for both politicians and spouses. ${ }^{6}$

\footnotetext{
${ }^{4} 12$-months trading window is considered to be the lower bound of long-horizon investing in Kothari and Warner (2007).

${ }^{5}$ The results are available from the author upon request.

${ }^{6} \mathrm{We}$ do not present the results of the spouses' retirement and trust portfolios' analyses to save space. The results are available upon request.
} 


\subsubsection{Powerful Family Members}

Members of Congress widely differ with respect to how much power they have in Congress. Following Karadas (2014a), we pool the politicians serving on the most powerful ten committees in each chamber into the powerful group and the rest of them into the non-powerful group. We argue that the families of the powerful politicians have more value-relevant in-

formation than those of the non-powerful politicians. Since there is no evidence of informed trading the accounts of the dependent children, we only focus on the transactions by spouses. Out of 19,559 transactions that spouses made, 16,304 of them were made by the spouses of the powerful politicians who we refer as the powerful spouses.

[Table 3.10 About Here]

[Table 3.11 About Here]

We present the results in Tables 3.10 and 3.11. The abnormal returns on the powerful spouses' portfolios are higher compared to the case where we evaluate the portfolio performance of the powerful and non-powerful spouses together (see Table 3.4). On the contrary, the non-powerful spouses do not demonstrate any evidence of informed trading. These findings lend empirical support for Hypothesis 4.

\subsection{Direct Comparison Between Politicians and Their Spouses}

Our analysis so far has grouped the transactions by all of the spouses together in comparing the performance of the spouses' portfolios to that of the politicians' portfolios. Nevertheless, according to Table 3.1, only 94 Type II politicians reported trades for themselves and for their spouses at the same time. In this section of our study, we compare the portfolio 
performance of these 94 politicians to that of their spouses. Such a comparison presents us with a unique opportunity to examine how politicians and their spouses differ with respect to their trading performance when they both trade. There are 12,882 transactions in the paired politicians' sample and 11,635 transactions in the paired spouses' transactions.

\section{[Table 3.12 About Here]}

\section{[Table 3.13 About Here]}

The results in Tables 3.12 and 3.13 demonstrate that when politicians and their spouses both trade, there is no evidence of informed trading on the part of the politicians. On the other hand, the portfolios of the spouses still have abnormal returns. Based on this evidence, we can now say that the portfolios of the politicians underperform those of their spouses. These results also bring up an interesting question: Do the spouses of the politicians who themselves do not trade (Type III politicians) trade on more or less value-relevant information compared to the spouses of the Type II politicians? We take up this question in the next section.

\subsection{Spouses of Type II Politicians versus Spouses of Type III Politicians}

The preceding section clearly shows that the spouses of the Type II politicians are informed traders. As we remember from Table 3.1, 57 out of 98 Type III politicians also reported trades for their spouses even though they themselves did not trade any common stocks during our sample period. Our analysis rests on the idea that members of Congress (politicians) share information with their family members. We are now faced with two different types of politicians who reported trades for their spouses: ones who also trade (Type II), and ones 
who do not trade (Type III).

Even though we do not know exactly why Type III politicians do not trade, it is reasonable to argue that they are either intentionally distancing themselves from trading stocks so that they do not have any conflict of interest in performing their duties or they do not have enough expertise in trading stocks. It is also likely that Type III politicians have the most valuable information, and they are intentionally exploiting their informational advantage by trading through their spouses' accounts in order to avoid any publicity. The results in Table 3.14 indicate that the spouses of the Type III politicians trade on less valuerelevant information than those of the Type II politicians. The abnormal returns for the Type II politicians' spouses have much higher abnormal returns than those for the Type III politicians' spouses (see Table 3.13). Furthermore, the abnormal returns in Table 3.14 are not robust to different weighting schemes. It is possible that the spouses of Type III politicians place both information-driven (for themselves) and regular (for politicians) trades, and combing these two different types of trades may lower the overall returns on their portfolios. On the contrary, the spouses of Type II politicians have their own trading account separate from Type II politicians to take advantage of private information, which may explain why the portfolios of Type II politicians' spouses outperform those of Type III politicians' spouses.

[Table 3.14 About Here]

\subsection{Conclusion}

The previous studies lump the transactions by politicians and their family members together. In this study, we separately examine the information content of common stock transactions by politicians and their family members. We provide evidence that politicians and their 
spouses trade on value-relevant information, but the content of information is less timesensitive for spouses. We also find that the transactions in tax-deferred trading accounts such as individual retirement accounts (IRAs) contain less valuable information than those in taxable trading accounts for both politicians and their spouses, which suggest that politicians and their spouses use these investment tools mainly for tax saving purposes. Furthermore, we document that the spouses of the powerful politicians do better in their investments than those of the non-powerful politicians with annualized abnormal returns ranging from $5.6 \%$ to 8.0\% under the 3-month holding period. The direct comparison between politicians and their spouses reveals that the portfolios of politicians underperform those of their spouses. Finally, we find that the spouses of Type II politicians (politicians who trade stocks) invest in stocks based on much more value-relevant information than the spouses of Type III politicians (politicians who do not trade stocks). Overall, these results suggest that politicians exploit some of their value-relevant information trading through the accounts of their spouses. There is a possibility that some spouses may obtain private information on their own due to their influential positions in the lobbying industry or similar places. We hope that future research takes on this interesting issue. 


\section{Table 3.1: Politician Types and Number of Transactions}

This table presents information on the types of the politicians (filer types) based on their trading patterns and the number of transactions these filers report. Members of Congress report common stock transactions for themselves (politicians, P), their spouses (S), dependent children (D), and finally for the joint accounts that they have with their family members $(\mathrm{J})$. These four groups represent all of the account types in our dataset, which we construct based on the raw data from Center of Responsive Politics. Type I politicians are the ones who report transactions only for themselves. Type II politicians report trades for themselves and for their family members. Type III politicians report trades only for their family members. Panel A provides information on the breakdown of how many account types each filer type reports. For example, there are 98 Type III politicians, and 17 of them reported trades for their dependent children' accounts. Panel $\mathrm{B}$ presents information on the number of transaction for each account type. For example, Type II politicians reported 17,164 transactions for themselves and 537 transactions for their dependent children.

\begin{tabular}{lrrrr} 
& \multicolumn{4}{c}{ Panel A: Filer and Account Types } \\
Account Type & Type I & Type II & Type III & Total \\
\hline P & 175 & 130 & 98 & 403 \\
D & 0 & 21 & 17 & 38 \\
S & 0 & 94 & 57 & 151 \\
J & 0 & 49 & 52 & 101 \\
\hline Total & 175 & 294 & 224 & 693
\end{tabular}

Panel B: Number of Transactions

\begin{tabular}{lrrrr} 
Account Type & Type I & Type II & Type III & Total \\
\hline P & 17,016 & 17,164 & 0 & 34,180 \\
D & 0 & 537 & 2,063 & 2,600 \\
S & 0 & 11,635 & 7,924 & 19,559 \\
J & 0 & 3,176 & 2,483 & 5,659 \\
\hline Total & 17,016 & 32,512 & 12,470 & 61,998
\end{tabular}




\section{Table 3.2: Descriptive Statistics}

This table presents the descriptive statistics of the transaction values for each account type. We have four different account types in our dataset: politicians $(\mathrm{P})$, spouses $(\mathrm{S})$, dependent children $(\mathrm{D})$, and joint transactions $(\mathrm{J})$. We obtain the raw transactions data over the 2004-2010 period from Center for Responsive Politics. We only keep transactions referring to US common stocks trading on major US exchanges.

\begin{tabular}{rrrrrr} 
Account Type & $\mathbf{N}$ & Mean & StdDev & Minimum & Maximum \\
\hline P & 34,180 & 21,162 & 454,129 & 100 & $50,000,001$ \\
D & 2,600 & 18,824 & 90,061 & 102 & $3,000,001$ \\
S & 19,559 & 49,535 & 506,198 & 103 & $50,000,001$ \\
J & 5,659 & 19,791 & 66,986 & 100 & $3,000,001$ \\
\hline
\end{tabular}




\section{Figure 3.1: CARs on the Long/Short (Buy-Minus-Sell) Transactions}

This table presents the cumulative abnormal returns (CARs) on the transactions in the politician (transactions by politicians), and the family samples (transactions by the family members of politicians) for the 252 trading days following the event day (transaction date). We first separately calculate the CARs for both buy and sell samples and then subtract the CARs on the sell transactions from those on the buy transactions. We obtain the transactions data from Center for Responsive Politics, the stock returns from CRSP, and the risk-free rate from WRDS. We only keep the U.S. domestic stocks (CRSP share code 10 or 11) listed on NYSE, AMEX, or NASDAQ. All returns are in percentages.
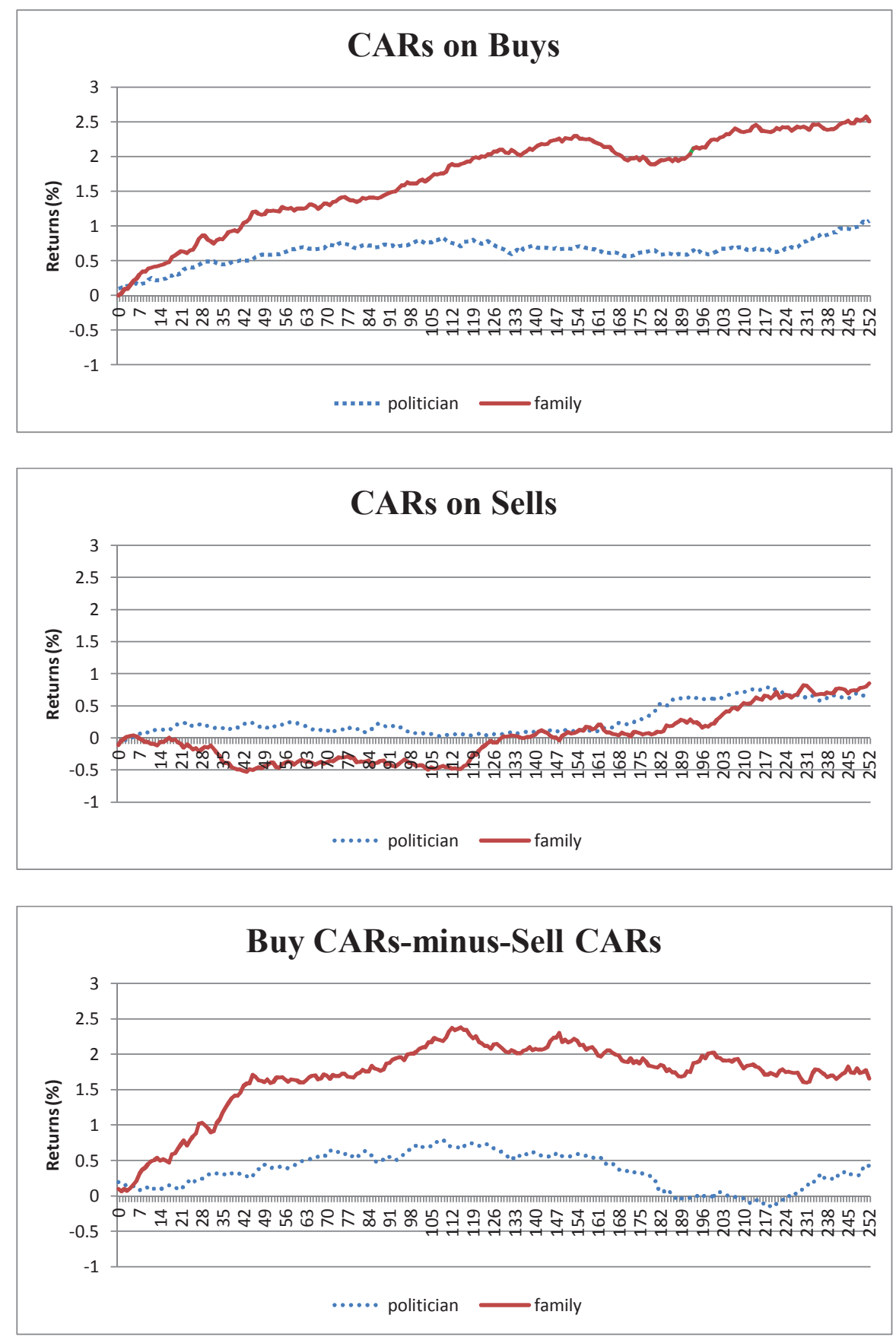
Figure 3.2: Calendar Time Portfolio Chart

This chart presents the four different weighting schemes used to calculate the calendartime portfolio returns. The word member is interchangeably used for trader.

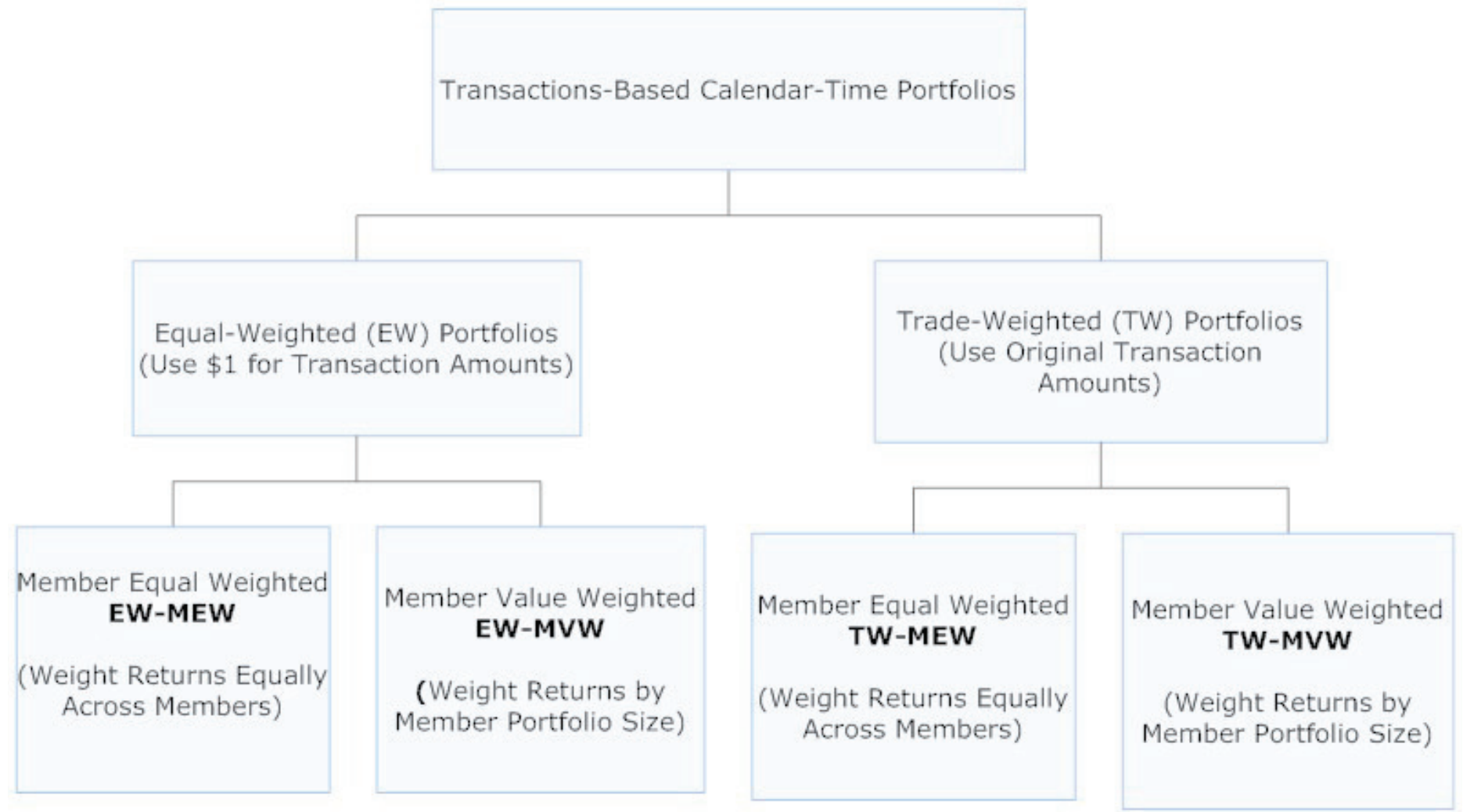




\section{Table 3.3: Politicians Only}

This table presents average monthly raw and risk-adjusted returns (alphas) in percentages over 2004M012011M12 on the buy-minus-sell portfolios from the transactions in NYSE/AMEX/NASDAQ common stocks by the politicians only. Transactions data is from Center for Responsive Politics, stock returns from CRSP, and five factors and risk-free rate from WRDS. Daily portfolio returns are calculated using four different weighting schemes under holding periods from 1 week to 12 months and compounded to monthly returns. Newey-West robust t-statistics (three lags) are in parenthesis.* , **, *** denote 10, 5, and $1 \%$ significance levels.

\begin{tabular}{|c|c|c|c|c|c|c|}
\hline Holding Period (Months): & $1 / 4$ & 1 & 2 & 3 & 6 & 12 \\
\hline \multicolumn{7}{|c|}{ Panel A: Equal-Weighted Transactions and Equal-Weighted Portfolios (EW-MEW) } \\
\hline \multirow[t]{2}{*}{ Avg. Return } & $1.991^{* * *}$ & $0.531^{* *}$ & 0.376 & 0.235 & -0.039 & -0.034 \\
\hline & $(3.38)$ & $(2.05)$ & $(1.58)$ & $(1.09)$ & $(-0.23)$ & $(-0.27)$ \\
\hline \multirow{2}{*}{ CAPM Alpha } & $2.112^{* * *}$ & $0.577^{* *}$ & $0.399^{*}$ & 0.252 & -0.037 & -0.037 \\
\hline & $(4.15)$ & $(2.53)$ & $(1.87)$ & $(1.13)$ & $(-0.24)$ & $(-0.31)$ \\
\hline \multirow{2}{*}{ FF Alpha } & $2.038^{* * *}$ & $0.602^{* *}$ & $0.437^{* *}$ & 0.304 & -0.009 & -0.033 \\
\hline & $(4.14)$ & $(2.52)$ & $(2.16)$ & $(1.46)$ & $(-0.06)$ & $(-0.29)$ \\
\hline \multirow[t]{2}{*}{ Carhart Alpha } & $2.038^{* * *}$ & $0.596^{* *}$ & $0.426^{* *}$ & 0.294 & -0.021 & -0.035 \\
\hline & $(4.13)$ & $(2.47)$ & $(2.07)$ & (1.37) & $(-0.15)$ & $(-0.30)$ \\
\hline \multirow{2}{*}{ 5-Factor Alpha } & $2.012^{* * *}$ & $0.572^{* *}$ & $0.409^{*}$ & 0.284 & -0.009 & -0.022 \\
\hline & $(3.61)$ & $(2.22)$ & $(1.98)$ & $(1.27)$ & $(-0.06)$ & $(-0.17)$ \\
\hline \multicolumn{7}{|c|}{ Panel B: Equal-Weighted Transactions and Value-Weighted Portfolios (EW-MVW) } \\
\hline \multirow{2}{*}{ Avg. Return } & $1.155^{* * *}$ & 0.198 & 0.119 & 0.091 & 0.000 & -0.074 \\
\hline & $(2.80)$ & $(0.94)$ & $(0.72)$ & $(0.57)$ & $(0.00)$ & $(-0.83)$ \\
\hline \multirow[t]{2}{*}{ CAPM Alpha } & $1.202^{* * *}$ & 0.232 & 0.166 & 0.135 & 0.035 & -0.058 \\
\hline & $(3.20)$ & (1.20) & (1.33) & (1.13) & $(0.40)$ & $(-0.74)$ \\
\hline \multirow[t]{2}{*}{ FF Alpha } & $1.174^{* * *}$ & 0.241 & 0.171 & 0.146 & 0.043 & -0.058 \\
\hline & $(3.19)$ & (1.31) & $(1.45)$ & (1.32) & $(0.53)$ & $(-0.78)$ \\
\hline \multirow[t]{2}{*}{ Carhart Alpha } & $1.179^{* * *}$ & 0.241 & 0.161 & 0.133 & 0.031 & -0.065 \\
\hline & $(3.26)$ & (1.29) & $(1.22)$ & $(0.99)$ & (0.39) & $(-0.94)$ \\
\hline \multirow{2}{*}{ 5-Factor Alpha } & $1.006^{* *}$ & 0.160 & 0.091 & 0.095 & -0.003 & -0.107 \\
\hline & $(2.48)$ & $(0.77)$ & $(0.62)$ & $(0.63)$ & $(-0.04)$ & $(-1.65)$ \\
\hline \multicolumn{7}{|c|}{ Panel C: Value-Weighted Transactions and Equal-Weighted Portfolios (TW-MEW) } \\
\hline \multirow[t]{2}{*}{ Avg. Return } & $1.929^{* * *}$ & $0.526^{* *}$ & 0.339 & 0.190 & -0.066 & -0.038 \\
\hline & (3.09) & (2.03) & (1.38) & $(0.87)$ & $(-0.38)$ & $(-0.28)$ \\
\hline \multirow[t]{2}{*}{ CAPM Alpha } & $2.068^{* * *}$ & $0.564^{* *}$ & 0.351 & 0.195 & -0.075 & -0.049 \\
\hline & $(3.98$ & $(2.40)$ & (1.57) & $(0.82)$ & $(-0.46)$ & $(-0.38)$ \\
\hline \multirow[t]{2}{*}{ FF Alpha } & $1.989 * * *$ & $0.584^{* *}$ & $0.393^{*}$ & 0.246 & -0.051 & -0.044 \\
\hline & $(3$. & & (1.83) & (1.10) & $(-0.31)$ & $(-0.34)$ \\
\hline \multirow[t]{2}{*}{ Carhart Alpha } & $1.988^{* * *}$ & $0.579^{* *}$ & $0.383^{*}$ & 0.237 & -0.061 & -0.043 \\
\hline & & & $(1.75)$ & $(1.05)$ & $(-0.39)$ & $(-0.34)$ \\
\hline \multirow[t]{2}{*}{ 5-Factor Alpha } & $1.951^{* * *}$ & $0.581^{* *}$ & $0.374^{*}$ & 0.231 & -0.038 & -0.018 \\
\hline & $(3.38)$ & $(2.17)$ & $(1.74)$ & $(0.99)$ & $(-0.24)$ & $(-0.13)$ \\
\hline \multicolumn{7}{|c|}{ Panel D: Value-Weighted Transactions and Value-Weighted Portfolios (TW-MVW) } \\
\hline \multirow[t]{2}{*}{ Avg. Return } & 0.544 & -0.238 & -0.343 & -0.334 & -0.305 & -0.152 \\
\hline & $(0.95)$ & $(-0.57)$ & $(-0.99)$ & $(-1.07)$ & $(-1.22)$ & $(-0.94)$ \\
\hline \multirow[t]{2}{*}{ CAPM Alpha } & 0.600 & -0.242 & -0.351 & -0.345 & -0.292 & -0.146 \\
\hline & $(1.15)$ & $(-0.76)$ & $(-1.02)$ & $(-1.07)$ & $(-1.18)$ & $(-0.98)$ \\
\hline \multirow[t]{2}{*}{ FF Alpha } & 0.667 & -0.168 & -0.307 & -0.312 & -0.289 & -0.142 \\
\hline & $(1.24)$ & $(-0.54)$ & $(-0.93)$ & $(-0.98)$ & $(-1.15)$ & $(-0.95)$ \\
\hline \multirow[t]{2}{*}{ Carhart Alpha } & 0.648 & -0.191 & -0.335 & -0.334 & -0.305 & -0.145 \\
\hline & (1.17) & $(-0.56)$ & $(-0.98)$ & $(-1.04)$ & $(-1.24)$ & $(-0.99)$ \\
\hline 5-Factor Alpha & 0.571 & -0.175 & -0.444 & -0.485 & -0.399 & -0.210 \\
\hline & $(0.93)$ & $(-0.44)$ & $(-1.20)$ & $(-1.38)$ & $(-1.53)$ & $(-1.36)$ \\
\hline
\end{tabular}




\section{Table 3.4: Spouses Only}

This table presents average monthly raw and risk-adjusted returns (alphas) in percentages over 2004M012011M12 on the buy-minus-sell portfolios from the transactions in NYSE/AMEX/NASDAQ common stocks by the politicians' spouses only. Transactions data is from Center for Responsive Politics, stock returns from CRSP, and five factors and risk-free rate from WRDS. Daily portfolio returns are calculated using four different weighting schemes under holding periods from 1 week to 12 months and compounded to monthly returns. Newey-West robust t-statistics (three lags) are in parenthesis.*, ${ }^{* *},{ }^{* * *}$ denote 10 , 5 , and $1 \%$ significance levels.

\begin{tabular}{|c|c|c|c|c|c|c|}
\hline \multirow{2}{*}{$\begin{array}{l}\text { Holding Period (Months): } \\
\text { Panel A. Equal-Weighte }\end{array}$} & $1 / 4$ & 1 & 2 & 3 & 6 & 12 \\
\hline & d Transac & ions and & qual-Weigl & ed Portfol & Ss (EW-M & $\overline{\mathrm{EW})}$ \\
\hline \multirow[t]{2}{*}{ Avg. Return } & 0.977 & 0.244 & 0.491 & $0.484^{*}$ & 0.163 & 0.039 \\
\hline & $(1.54)$ & $(0.61)$ & $(1.64)$ & $(1.96)$ & $(0.61)$ & $(0.18)$ \\
\hline \multirow[t]{2}{*}{ CAPM Alpha } & $1.038^{*}$ & 0.300 & $0.562^{* *}$ & $0.552^{* *}$ & 0.237 & 0.080 \\
\hline & $(1.88)$ & $(0.88)$ & $(2.43)$ & $(2.43)$ & $(1.03)$ & $(0.39)$ \\
\hline \multirow[t]{2}{*}{ FF Alpha } & $1.079 * *$ & 0.239 & $0.552^{* *}$ & $0.528^{* *}$ & 0.254 & 0.096 \\
\hline & $(1.99)$ & $(0.77)$ & $(2.50)$ & $(2.45)$ & (1.13) & $(0.50)$ \\
\hline \multirow[t]{2}{*}{ Carhart Alpha } & $1.090^{* *}$ & 0.245 & $0.546^{* *}$ & $0.519^{* *}$ & 0.246 & 0.091 \\
\hline & $(2.08)$ & $(0.75)$ & $(2.49)$ & $(2.39)$ & $(1.13)$ & $(0.49)$ \\
\hline \multirow[t]{2}{*}{ 5-Factor Alpha } & $1.108^{*}$ & 0.164 & $0.519^{* *}$ & $0.558^{* *}$ & 0.307 & 0.114 \\
\hline & $(1.88)$ & $(0.47)$ & $(2.25)$ & $(2.43)$ & $(1.34)$ & $(0.55)$ \\
\hline \multicolumn{7}{|c|}{ Panel B: Equal-Weighted Transactions and Value-Weighted Portfolios (EW-MVW) } \\
\hline \multirow[t]{2}{*}{ Avg. Return } & 0.908 & $0.521^{* *}$ & $0.590^{* * *}$ & $0.451^{* * *}$ & $0.369^{* *}$ & $0.216^{*}$ \\
\hline & $(1.60)$ & $(2.01)$ & $(2.94)$ & $(2.64)$ & $(2.41)$ & $(1.75)$ \\
\hline \multirow[t]{2}{*}{ CAPM Alpha } & 0.934 & $0.526^{* *}$ & $0.589^{* * *}$ & $0.451^{* * *}$ & $0.375^{* *}$ & $0.223^{*}$ \\
\hline & $(1.63)$ & $(2.51)$ & $(3.52)$ & $(2.92)$ & $(2.40)$ & $(1.76)$ \\
\hline \multirow[t]{2}{*}{ FF Alpha } & 0.902 & $0.485^{* *}$ & $0.584^{* * *}$ & $0.430^{* * *}$ & $0.357^{* *}$ & $0.215^{*}$ \\
\hline & $(1.61)$ & $(2.37)$ & $(3.60)$ & $(2.89)$ & $(2.38)$ & $(1.84)$ \\
\hline \multirow[t]{2}{*}{ Carhart Alpha } & 0.908 & $0.486^{* *}$ & $0.581^{* * *}$ & $0.421^{* * *}$ & $0.345^{* *}$ & $0.208^{*}$ \\
\hline & $(1.64)$ & $(2.35)$ & $(3.59)$ & $(2.95)$ & $(2.49)$ & $(1.86)$ \\
\hline \multirow[t]{2}{*}{ 5-Factor Alpha } & 0.987 & $0.562^{* * *}$ & $0.668^{* * *}$ & $0.524^{* * *}$ & $0.368^{* *}$ & $0.231^{*}$ \\
\hline & $(1.63)$ & $(2.77)$ & $(3.67)$ & $(3.05)$ & $(2.28)$ & $(1.75)$ \\
\hline \multicolumn{7}{|c|}{ Panel C: Value-Weighted Transactions and Equal-Weighted Portfolios (TW-MEW) } \\
\hline \multirow[t]{2}{*}{ Avg. Return } & 1.012 & 0.146 & 0.445 & $0.494^{* *}$ & 0.135 & 0.037 \\
\hline & $(1.57)$ & $(0.37)$ & $(1.53)$ & $(2.00)$ & $(0.51)$ & $(0.18)$ \\
\hline \multirow[t]{2}{*}{ CAPM Alpha } & $1.063^{*}$ & 0.197 & $0.497^{* *}$ & $0.549^{* *}$ & 0.198 & 0.064 \\
\hline & $(1.79)$ & $(0.58)$ & $(2.15)$ & $(2.28)$ & $(0.91)$ & $(0.33)$ \\
\hline \multirow[t]{2}{*}{ FF Alpha } & $1.103^{*}$ & 0.139 & $0.479^{* *}$ & $0.518^{* *}$ & 0.208 & 0.077 \\
\hline & $(1.88)$ & $(0.45)$ & $(2.21)$ & $(2.36)$ & $(0.97)$ & $(0.41)$ \\
\hline \multirow[t]{2}{*}{ Carhart Alpha } & $1.115^{*}$ & 0.144 & $0.472^{* *}$ & $0.508^{* *}$ & 0.203 & 0.075 \\
\hline & $(1.98)$ & $(0.45)$ & $(2.22)$ & $(2.31)$ & $(0.97)$ & $(0.40)$ \\
\hline \multirow[t]{2}{*}{ 5-Factor Alpha } & $1.154^{*}$ & 0.072 & $0.481^{* *}$ & $0.573^{* *}$ & 0.298 & 0.111 \\
\hline & $(1.84)$ & $(0.21)$ & $(2.23)$ & $(2.54)$ & (1.39) & $(0.56)$ \\
\hline \multicolumn{7}{|c|}{ Panel D: Value-Weighted Transactions and Value-Weighted Portfolios (TW-MVW) } \\
\hline \multirow[t]{2}{*}{ Avg. Return } & $1.414^{* *}$ & 0.526 & 0.502 & $0.532^{* *}$ & $0.274^{*}$ & 0.080 \\
\hline & $(2.08)$ & $(1.47)$ & $(1.60)$ & $(2.25)$ & $(1.74)$ & $(0.59)$ \\
\hline \multirow[t]{2}{*}{ CAPM Alpha } & $1.404^{*}$ & 0.522 & $0.496^{* *}$ & $0.531^{* *}$ & $0.281^{*}$ & 0.079 \\
\hline & $(1.84)$ & $(1.65)$ & $(2.02)$ & $(2.60)$ & $(1.76)$ & $(0.61)$ \\
\hline \multirow[t]{2}{*}{ FF Alpha } & $1.452^{*}$ & $0.528^{*}$ & $0.509^{* *}$ & $0.520^{* * *}$ & $0.284^{*}$ & 0.086 \\
\hline & $(1.93)$ & $(1.70)$ & $(2.19)$ & $(2.67)$ & $(1.74)$ & $(0.72)$ \\
\hline \multirow[t]{2}{*}{ Carhart Alpha } & $1.470^{* *}$ & $0.532^{*}$ & $0.516^{* *}$ & $0.523^{* * *}$ & $0.287^{*}$ & 0.085 \\
\hline & $(2.05)$ & (1.69) & $(2.18)$ & $(2.64)$ & $(1.75)$ & $(0.71)$ \\
\hline 5-Factor Alpha & $1.599^{* *}$ & 0.507 & $0.534^{* *}$ & $0.593^{* *}$ & $0.324^{*}$ & 0.098 \\
\hline & $(2.11)$ & (1.61) & $(2.06)$ & $(2.64)$ & $(1.86)$ & $(0.77)$ \\
\hline
\end{tabular}




\section{Table 3.5: Dependent Children Only}

This table presents average monthly raw and risk-adjusted returns (alphas) in percentages over 2004M012011M12 on the buy-minus-sell portfolios from the transactions in NYSE/AMEX/NASDAQ common stocks by the politicians' dependent children only. Transactions data is from Center for Responsive Politics, stock returns from CRSP, and five factors and risk-free rate from WRDS. Daily portfolio returns are calculated using four different weighting schemes under holding periods from 1 week to 12 months and compounded to monthly returns. Newey-West robust t-statistics (three lags) are in parenthesis.*, **, $* * *$ denote 10,5 , and $1 \%$ significance levels.

\begin{tabular}{|c|c|c|c|c|c|c|}
\hline \multirow{2}{*}{$\begin{array}{l}\text { Holding Period (Months): } \\
\text { Panel A: Equal-Weighted }\end{array}$} & $1 / 4$ & 1 & 2 & 3 & 6 & 12 \\
\hline & Transactions & and Equ & 1-Weigh & ed Port & lios (E) & -MEW) \\
\hline \multirow[t]{2}{*}{ Avg. Return } & $-2.685^{* *}$ & -0.724 & 0.171 & 0.281 & -0.081 & -0.313 \\
\hline & $(-2.30)$ & $(-0.86)$ & $(0.22)$ & $(0.38)$ & $(-0.12)$ & $(-0.49)$ \\
\hline \multirow{2}{*}{ CAPM Alpha } & $-3.217^{* *}$ & -0.460 & 0.193 & 0.308 & -0.050 & -0.213 \\
\hline & $(-2.40)$ & $(-0.57)$ & $(0.28)$ & $(0.50)$ & $(-0.07)$ & $(-0.41)$ \\
\hline \multirow[t]{2}{*}{ FF Alpha } & $-3.212^{* *}$ & -0.429 & 0.441 & 0.524 & 0.079 & -0.125 \\
\hline & $(-2.39)$ & $(-0.57)$ & $(0.66)$ & $(0.81)$ & $(0.16)$ & $(-0.29)$ \\
\hline \multirow[t]{2}{*}{ Carhart Alpha } & $-3.270 * *$ & -0.430 & 0.386 & 0.458 & 0.044 & -0.154 \\
\hline & $(-2.55)$ & $(-0.57)$ & $(0.57)$ & $(0.70)$ & $(0.09)$ & $(-0.35)$ \\
\hline \multirow[t]{2}{*}{ 5-Factor Alpha } & -1.980 & 0.202 & 0.716 & 0.897 & 0.044 & -0.164 \\
\hline & $(-1.47)$ & $(0.25)$ & $(1.07)$ & $(1.32)$ & $(0.08)$ & $(-0.34)$ \\
\hline \multicolumn{7}{|c|}{ Panel B: Equal-Weighted Transactions and Value-Weighted Portfolios (EW-MVW) } \\
\hline \multirow[t]{2}{*}{ Avg. Return } & $-2.626^{* *}$ & -0.273 & 0.403 & 0.490 & 0.142 & 0.242 \\
\hline & $(-2.17)$ & $(-0.34)$ & $(0.58)$ & $(0.84)$ & $(0.28)$ & $(0.69)$ \\
\hline \multirow[t]{2}{*}{ CAPM Alpha } & $-3.310^{* *}$ & -0.052 & 0.374 & 0.469 & 0.054 & 0.181 \\
\hline & $(-2.42)$ & $(-0.06)$ & $(0.54)$ & $(0.86)$ & $(0.10)$ & $(0.62)$ \\
\hline \multirow[t]{2}{*}{ FF Alpha } & $-3.313^{* *}$ & -0.057 & 0.531 & 0.610 & 0.137 & 0.226 \\
\hline & $(-2.38)$ & $(-0.07)$ & $(0.79)$ & $(1.10)$ & $(0.30)$ & $(0.86)$ \\
\hline \multirow[t]{2}{*}{ Carhart Alpha } & $-3.408 * * *$ & -0.060 & 0.512 & 0.591 & 0.133 & 0.223 \\
\hline & $(-2.68)$ & $(-0.08)$ & $(0.77)$ & $(1.08)$ & $(0.30)$ & $(0.84)$ \\
\hline \multirow[t]{2}{*}{ 5-Factor Alpha } & -2.212 & 0.451 & 0.677 & 0.756 & 0.137 & 0.129 \\
\hline & $(-1.65)$ & $(0.50)$ & $(1.02)$ & $(1.28)$ & $(0.27)$ & $(0.45)$ \\
\hline \multicolumn{7}{|c|}{ Panel C: Value-Weighted Transactions and Equal-Weighted Portfolios (TW-MEW) } \\
\hline \multirow[t]{2}{*}{ Avg. Return } & $-2.778^{* *}$ & -0.874 & 0.041 & 0.179 & 0.066 & -0.406 \\
\hline & $(-2.38)$ & $(-1.04)$ & $(0.05)$ & $(0.24)$ & $(0.10)$ & $(-0.64)$ \\
\hline \multirow[t]{2}{*}{ CAPM Alpha } & $-3.254^{* *}$ & -0.592 & 0.072 & 0.215 & 0.135 & -0.315 \\
\hline & $(-2.34)$ & $(-0.73)$ & $(0.10)$ & $(0.33)$ & $(0.21)$ & $(-0.65)$ \\
\hline \multirow[t]{2}{*}{ FF Alpha } & $-3.254^{* *}$ & -0.566 & 0.319 & 0.448 & 0.249 & -0.224 \\
\hline & $(-2.32)$ & $(-0.74)$ & $(0.48)$ & $(0.70)$ & $(0.50)$ & $(-0.54)$ \\
\hline \multirow[t]{2}{*}{ Carhart Alpha } & $-3.321^{* *}$ & -0.567 & 0.272 & 0.391 & 0.222 & -0.247 \\
\hline & $(-2.50)$ & $(-0.75)$ & $(0.40)$ & $(0.59)$ & $(0.43)$ & $(-0.60)$ \\
\hline \multirow[t]{2}{*}{ 5-Factor Alpha } & -2.161 & 0.069 & 0.580 & 0.778 & 0.248 & -0.253 \\
\hline & $(-1.54)$ & $(0.09)$ & $(0.87)$ & $(1.12)$ & $(0.47)$ & $(-0.56)$ \\
\hline \multicolumn{7}{|c|}{ Panel D: Value-Weighted Transactions and Value-Weighted Portfolios (TW-MVW) } \\
\hline \multirow[t]{2}{*}{ Avg. Return } & $-2.473^{* *}$ & -0.166 & 0.353 & 0.492 & 0.883 & 0.366 \\
\hline & $(-2.07)$ & $(-0.21)$ & & $(0.79)$ & & $(0.96)$ \\
\hline \multirow[t]{2}{*}{ CAPM Alpha } & $-3.112^{* *}$ & 0.062 & 0.325 & 0.476 & 0.865 & 0.334 \\
\hline & $(-2.32)$ & $(0.07)$ & & $(0.73)$ & $(1.24)$ & $(0.83)$ \\
\hline \multirow[t]{2}{*}{ FF Alpha } & $-3.126^{* *}$ & 0.072 & 0.507 & 0.622 & 0.892 & 0.329 \\
\hline & $(-2.29)$ & $(0.09)$ & $(0.71)$ & $(0.96)$ & $(1.52)$ & $(0.93)$ \\
\hline \multirow[t]{2}{*}{ Carhart Alpha } & $-3.222^{* *}$ & 0.068 & 0.500 & 0.620 & 0.906 & 0.332 \\
\hline & $(-2.60)$ & $(0.08)$ & $(0.71)$ & $(0.96)$ & $(1.58)$ & $(0.94)$ \\
\hline 5-Factor Alpha & -2.199 & 0.531 & 0.610 & 0.699 & 0.808 & 0.258 \\
\hline & $(-1.64)$ & $(0.57)$ & $(0.84)$ & $(1.01)$ & $(1.33)$ & $(0.74)$ \\
\hline
\end{tabular}




\section{Table 3.6: Joint Portfolios Only}

This table presents average monthly raw and risk-adjusted returns (alphas) in percentages over 2004M012011M12 on the buy-minus-sell portfolios from the joint transactions in NYSE/AMEX/NASDAQ common stocks by the politicians and their family members only. Transactions data is from Center for Responsive Politics, stock returns from CRSP, and five factors and risk-free rate from WRDS. Daily portfolio returns are calculated using four different weighting schemes under holding periods from 1 week to 12 months and compounded to monthly returns. Newey-West robust t-statistics (three lags) are in parenthesis. ${ }^{*}, * *, * *$ denote 10,5 , and $1 \%$ significance levels.

\begin{tabular}{|c|c|c|c|c|c|c|}
\hline Holding Period (Months): & $1 / 4$ & 1 & 2 & 3 & 6 & 12 \\
\hline \multicolumn{7}{|c|}{ Panel A: Equal-Weighted Transactions and Equal-Weighted Portfolios (EW-MEW) } \\
\hline \multirow[t]{2}{*}{ Avg. Return } & 0.412 & 0.411 & 0.420 & 0.203 & 0.272 & 0.154 \\
\hline & $(0.39)$ & $(0.81)$ & $(0.87)$ & $(0.57)$ & $(1.00)$ & $(0.54)$ \\
\hline \multirow[t]{2}{*}{ CAPM Alpha } & 0.418 & 0.448 & 0.433 & 0.191 & 0.265 & 0.197 \\
\hline & $(0.46)$ & $(1.15)$ & $(1.13)$ & $(0.57)$ & $(0.91)$ & $(0.84)$ \\
\hline \multirow[t]{2}{*}{ FF Alpha } & 0.462 & 0.371 & 0.406 & 0.271 & 0.295 & 0.198 \\
\hline & $(0.51)$ & $(1.00)$ & $(1.11)$ & $(0.87)$ & $(1.11)$ & $(0.90)$ \\
\hline \multirow[t]{2}{*}{ Carhart Alpha } & 0.448 & 0.360 & 0.403 & 0.270 & 0.302 & 0.203 \\
\hline & $(0.49)$ & $(0.96)$ & $(1.11)$ & $(0.87)$ & $(1.17)$ & $(0.94)$ \\
\hline \multirow[t]{2}{*}{ 5-Factor Alpha } & 0.670 & 0.435 & 0.430 & 0.276 & 0.205 & 0.222 \\
\hline & $(0.64)$ & $(0.98)$ & $(1.00)$ & $(0.80)$ & $(0.80)$ & (1.03) \\
\hline \multicolumn{7}{|c|}{ Panel B: Equal-Weighted Transactions and Value-Weighted Portfolios (EW-MVW) } \\
\hline \multirow[t]{2}{*}{ Avg. Return } & 0.276 & 0.312 & -0.180 & -0.093 & 0.196 & 0.020 \\
\hline & $(0.27)$ & $(0.68)$ & $(-0.44)$ & $(-0.34)$ & $(1.25)$ & $(0.11)$ \\
\hline \multirow[t]{2}{*}{ CAPM Alpha } & 0.206 & 0.352 & -0.174 & -0.144 & 0.174 & 0.012 \\
\hline & $(0.23)$ & $(0.87)$ & $(-0.54)$ & $(-0.60)$ & $(1.13)$ & $(0.09)$ \\
\hline \multirow[t]{2}{*}{ FF Alpha } & 0.234 & 0.295 & -0.160 & -0.100 & 0.169 & 0.002 \\
\hline & $(0.26)$ & $(0.82)$ & $(-0.53)$ & $(-0.45)$ & $(1.11)$ & $(0.01)$ \\
\hline \multirow[t]{2}{*}{ Carhart Alpha } & 0.230 & 0.286 & -0.164 & -0.101 & 0.175 & 0.007 \\
\hline & $(0.25)$ & $(0.82)$ & $(-0.56)$ & $(-0.46)$ & $(1.15)$ & $(0.05)$ \\
\hline \multirow[t]{2}{*}{ 5-Factor Alpha } & 0.484 & 0.416 & -0.107 & -0.086 & 0.186 & 0.056 \\
\hline & $(0.47)$ & $(1.08)$ & $(-0.34)$ & $(-0.38)$ & $(1.19)$ & $(0.45)$ \\
\hline \multicolumn{7}{|c|}{ Panel C: Value-Weighted Transactions and Equal-Weighted Portfolios (TW-MEW) } \\
\hline \multirow[t]{2}{*}{ Avg. Return } & 1.000 & 0.539 & 0.357 & 0.115 & 0.157 & 0.068 \\
\hline & $(0.96)$ & $(1.04)$ & $(0.70)$ & $(0.31)$ & $(0.58)$ & $(0.24)$ \\
\hline \multirow[t]{2}{*}{ CAPM Alpha } & 1.037 & 0.563 & 0.381 & 0.103 & 0.147 & 0.108 \\
\hline & (1.18) & (1.38) & $(0.94)$ & $(0.29)$ & $(0.50)$ & $(0.47)$ \\
\hline \multirow[t]{2}{*}{ FF Alpha } & 1.062 & 0.483 & 0.354 & 0.182 & 0.186 & 0.111 \\
\hline & $(1.22)$ & $(1.21)$ & $(0.89)$ & $(0.55)$ & $(0.69)$ & $(0.51)$ \\
\hline \multirow[t]{2}{*}{ Carhart Alpha } & 1.062 & 0.475 & 0.348 & 0.181 & 0.197 & 0.117 \\
\hline & $(1.22)$ & $(1.16)$ & $(0.89)$ & $(0.55)$ & $(0.77)$ & $(0.55)$ \\
\hline \multirow[t]{2}{*}{ 5-Factor Alpha } & 1.214 & 0.557 & 0.401 & 0.222 & 0.139 & 0.147 \\
\hline & $(1.28)$ & $(1.22)$ & $(0.86)$ & $(0.60)$ & $(0.54)$ & $(0.69)$ \\
\hline \multicolumn{7}{|c|}{ Panel D: Value-Weighted Transactions and Value-Weighted Portfolios (TW-MVW) } \\
\hline \multirow[t]{2}{*}{ Avg. Return } & 0.970 & 0.365 & -0.248 & -0.166 & $0.405^{*}$ & 0.260 \\
\hline & $(0.96)$ & $(0.77)$ & $(-0.56)$ & $(-0.49)$ & $(1.78)$ & $(1.25)$ \\
\hline \multirow[t]{2}{*}{ CAPM Alpha } & 0.932 & 0.379 & -0.234 & -0.232 & 0.386 & 0.247 \\
\hline & $(0.99)$ & $(1.03)$ & $(-0.57)$ & $(-0.68)$ & $(1.59)$ & $(1.47)$ \\
\hline \multirow[t]{2}{*}{ FF Alpha } & 0.939 & 0.337 & -0.185 & -0.208 & 0.382 & 0.228 \\
\hline & $(0.98)$ & $(0.89)$ & $(-0.46)$ & $(-0.60)$ & $(1.51)$ & $(1.37)$ \\
\hline \multirow[t]{2}{*}{ Carhart Alpha } & 0.957 & 0.334 & -0.187 & -0.205 & 0.387 & 0.232 \\
\hline & $(1.05)$ & $(0.89)$ & $(-0.47)$ & $(-0.58)$ & $(1.53)$ & $(1.38)$ \\
\hline 5-Factor Alpha & 1.323 & 0.511 & -0.090 & -0.105 & $0.527^{* *}$ & $0.352^{* *}$ \\
\hline & (1.32) & $(1.31)$ & $(-0.23)$ & $(-0.31)$ & $(2.18)$ & $(2.32)$ \\
\hline
\end{tabular}




\section{Table 3.7: Politicians' Retirement Portfolios}

This table presents average monthly raw and risk-adjusted returns (alphas) in percentages over 2004M012011M12 on the buy-minus-sell portfolios from the transactions in NYSE/AMEX/NASDAQ common stocks that the politicians made in their retirement accounts (IRAs and 401(k)s). Transactions data is from Center for Responsive Politics, stock returns from CRSP, and five factors and risk-free rate from WRDS. Daily portfolio returns are calculated using four different weighting schemes under holding periods from 1 week to 12 months and compounded to monthly returns. Newey-West robust t-statistics (three lags) are in parenthesis.*, ${ }^{* *}, * * *$ denote 10,5 , and $1 \%$ significance levels.

\begin{tabular}{|c|c|c|c|c|c|c|}
\hline Holding Period (Months): & $1 / 4$ & 1 & 2 & 3 & 6 & 12 \\
\hline \multicolumn{7}{|c|}{ 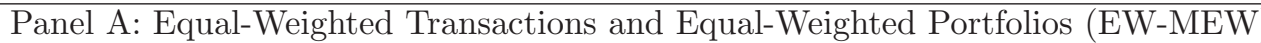 } \\
\hline \multirow[t]{2}{*}{ Avg. Return } & 1.949 & 0.305 & -0.008 & 0.056 & 0.138 & -0.038 \\
\hline & $(1.17)$ & $(0.39)$ & $(-0.01)$ & $(0.12)$ & $(0.30)$ & $(-0.11)$ \\
\hline \multirow[t]{2}{*}{ CAPM Alpha } & 2.001 & 0.334 & 0.167 & 0.159 & 0.180 & -0.039 \\
\hline & $(1.56)$ & $(0.39)$ & $(0.25)$ & $(0.33)$ & $(0.37)$ & $(-0.11)$ \\
\hline \multirow[t]{2}{*}{ FF Alpha } & 1.829 & 0.383 & 0.194 & 0.118 & 0.185 & -0.039 \\
\hline & $(1.51)$ & $(0.49)$ & $(0.32)$ & $(0.25)$ & $(0.41)$ & $(-0.11)$ \\
\hline \multirow[t]{2}{*}{ Carhart Alpha } & 1.533 & 0.381 & 0.212 & 0.114 & 0.175 & -0.035 \\
\hline & $(1.30)$ & $(0.49)$ & $(0.35)$ & $(0.24)$ & $(0.39)$ & $(-0.10)$ \\
\hline \multirow[t]{2}{*}{ 5-Factor Alpha } & 1.387 & 0.359 & -0.044 & 0.017 & 0.192 & -0.013 \\
\hline & $(1.10)$ & $(0.45)$ & $(-0.07)$ & $(0.04)$ & $(0.43)$ & $(-0.04)$ \\
\hline \multicolumn{7}{|c|}{ Panel B: Equal-Weighted Transactions and Value-Weighted Portfolios (EW-MVW) } \\
\hline \multirow[t]{2}{*}{ Avg. Return } & 1.245 & 0.150 & -0.398 & -0.040 & 0.177 & -0.071 \\
\hline & $(0.86)$ & $(0.23)$ & $(-0.74)$ & $(-0.10)$ & $(0.66)$ & $(-0.34)$ \\
\hline \multirow[t]{2}{*}{ CAPM Alpha } & 1.272 & 0.164 & -0.329 & 0.007 & 0.224 & -0.028 \\
\hline & $(1.13)$ & $(0.25)$ & $(-0.58)$ & $(0.02)$ & $(0.89)$ & $(-0.14)$ \\
\hline \multirow[t]{2}{*}{ FF Alpha } & 1.098 & 0.153 & -0.298 & 0.007 & 0.198 & -0.051 \\
\hline & $(1.05)$ & $(0.26)$ & $(-0.60)$ & $(0.02)$ & $(0.81)$ & $(-0.27)$ \\
\hline \multirow[t]{2}{*}{ Carhart Alpha } & 0.799 & 0.149 & -0.281 & 0.018 & 0.188 & -0.058 \\
\hline & $(0.76)$ & $(0.25)$ & $(-0.57)$ & $(0.05)$ & $(0.78)$ & $(-0.31)$ \\
\hline \multirow[t]{2}{*}{ 5-Factor Alpha } & 0.653 & 0.251 & -0.344 & 0.058 & 0.234 & -0.024 \\
\hline & $(0.60)$ & $(0.44)$ & $(-0.66)$ & $(0.15)$ & $(0.86)$ & $(-0.12)$ \\
\hline \multicolumn{7}{|c|}{ Panel C: Value-Weighted Transactions and Equal-Weighted Portfolios (TW-MEW) } \\
\hline \multirow[t]{2}{*}{ Avg. Return } & 1.910 & 0.134 & 0.008 & 0.088 & 0.084 & -0.086 \\
\hline & $(1.14)$ & $(0.17)$ & $(0.01)$ & $(0.19)$ & $(0.18)$ & $(-0.24)$ \\
\hline \multirow[t]{2}{*}{ CAPM Alpha } & 1.957 & 0.145 & 0.172 & 0.178 & 0.126 & -0.089 \\
\hline & $(1.48)$ & $(0.17)$ & $(0.26)$ & $(0.37)$ & $(0.26)$ & $(-0.23)$ \\
\hline \multirow[t]{2}{*}{ FF Alpha } & 1.772 & 0.176 & 0.198 & 0.142 & 0.128 & -0.084 \\
\hline & $(1.44)$ & $(0.22)$ & $(0.33)$ & $(0.30)$ & $(0.28)$ & $(-0.23)$ \\
\hline \multirow[t]{2}{*}{ Carhart Alpha } & 1.458 & 0.169 & 0.215 & 0.136 & 0.114 & -0.082 \\
\hline & $(1.22)$ & $(0.21)$ & $(0.36)$ & $(0.30)$ & $(0.25)$ & $(-0.23)$ \\
\hline \multirow[t]{2}{*}{ 5-Factor Alpha } & 1.319 & 0.267 & -0.060 & 0.015 & 0.120 & -0.069 \\
\hline & $(1.03)$ & $(0.33)$ & $(-0.09)$ & $(0.03)$ & $(0.27)$ & $(-0.19)$ \\
\hline \multicolumn{7}{|c|}{ Panel D: Value-Weighted Transactions and Value-Weighted Portfolios (TW-MVW) } \\
\hline \multirow[t]{2}{*}{ Avg. Return } & 2.005 & 0.074 & 0.171 & 0.460 & 0.349 & 0.084 \\
\hline & $(1.17)$ & $(0.08)$ & $(0.23)$ & $(0.96)$ & $(1.08)$ & $(0.35)$ \\
\hline \multirow[t]{2}{*}{ CAPM Alpha } & 2.066 & 0.133 & 0.335 & 0.524 & 0.374 & 0.108 \\
\hline & $(1.52)$ & $(0.16)$ & $(0.51)$ & $(1.15)$ & $(1.16)$ & $(0.47)$ \\
\hline \multirow[t]{2}{*}{ FF Alpha } & 1.873 & 0.092 & 0.287 & 0.521 & 0.349 & 0.086 \\
\hline & $(1.45)$ & $(0.12)$ & $(0.48)$ & $(1.21)$ & $(1.12)$ & $(0.38)$ \\
\hline \multirow[t]{2}{*}{ Carhart Alpha } & 1.515 & 0.083 & 0.311 & 0.534 & 0.342 & 0.077 \\
\hline & (1.20) & $(0.11)$ & $(0.53)$ & $(1.26)$ & (1.13) & $(0.35)$ \\
\hline 5-Factor Alpha & 1.462 & 0.216 & 0.262 & 0.590 & 0.391 & 0.109 \\
\hline & (1.09) & $(0.28)$ & $(0.41)$ & $(1.29)$ & $(1.24)$ & $(0.47)$ \\
\hline
\end{tabular}




\section{Table 3.8: Politicians' Trust Portfolios}

This table presents average monthly raw and risk-adjusted returns (alphas) in percentages over 2004M012011M12 on the buy-minus-sell portfolios from the transactions in NYSE/AMEX/NASDAQ common stocks that the politicians made via their trusts. Transactions data is from Center for Responsive Politics, stock returns from CRSP, and five factors and risk-free rate from WRDS. Daily portfolio returns are calculated using four different weighting schemes under holding periods from 1 week to 12 months and compounded to monthly returns. Newey-West robust t-statistics (three lags) are in parenthesis.*, **, *** denote 10,5 , and $1 \%$ significance levels.

\begin{tabular}{|c|c|c|c|c|c|c|}
\hline Holding Period (Months): & $1 / 4$ & 1 & 2 & 3 & 6 & 12 \\
\hline \multicolumn{7}{|c|}{ Panel A: Equal-Weighted Transactions and Equal-Weighted Portfolios (EW-MEW) } \\
\hline Avg. Return & $\begin{array}{c}-1.588^{*} \\
(-1.74)\end{array}$ & $\begin{array}{c}-1.476^{* *} \\
(-2.09)\end{array}$ & $\begin{array}{l}-0.388 \\
(-0.84)\end{array}$ & $\begin{array}{l}-0.277 \\
(-0.53)\end{array}$ & $\begin{array}{l}-0.145 \\
(-0.37)\end{array}$ & $\begin{array}{l}-0.306 \\
(-0.80)\end{array}$ \\
\hline CAPM Alpha & $\begin{array}{l}-1.582 \\
(-1.63)\end{array}$ & $\begin{array}{c}-1.468^{* *} \\
(-2.07)\end{array}$ & $\begin{array}{l}-0.342 \\
(-0.69)\end{array}$ & $\begin{array}{l}-0.199 \\
(-0.34)\end{array}$ & $\begin{array}{l}-0.089 \\
(-0.24)\end{array}$ & $\begin{array}{l}-0.225 \\
(-0.76)\end{array}$ \\
\hline FF Alpha & $\begin{array}{l}-1.491 \\
(-1.58)\end{array}$ & $\begin{array}{c}-1.348^{* *} \\
(-1.99)\end{array}$ & $\begin{array}{l}-0.311 \\
(-0.61)\end{array}$ & $\begin{array}{l}-0.183 \\
(-0.32)\end{array}$ & $\begin{array}{l}-0.064 \\
(-0.17)\end{array}$ & $\begin{array}{l}-0.241 \\
(-0.85)\end{array}$ \\
\hline Carhart Alpha & $\begin{array}{l}-1.398 \\
(-1.54)\end{array}$ & $\begin{array}{c}-1.435^{* *} \\
(-2.30)\end{array}$ & $\begin{array}{l}-0.321 \\
(-0.66)\end{array}$ & $\begin{array}{l}-0.199 \\
(-0.35)\end{array}$ & $\begin{array}{l}-0.094 \\
(-0.27)\end{array}$ & $\begin{array}{l}-0.256 \\
(-0.92)\end{array}$ \\
\hline 5-Factor Alpha & $\begin{array}{c}-1.960^{*} \\
(-1.92)\end{array}$ & $\begin{array}{c}-1.515^{* *} \\
(-2.42)\end{array}$ & $\begin{array}{l}-0.559 \\
(-1.07)\end{array}$ & $\begin{array}{l}-0.568 \\
(-1.03)\end{array}$ & $\begin{array}{l}-0.304 \\
(-0.88)\end{array}$ & $\begin{array}{c}-0.507^{*} \\
(-1.89)\end{array}$ \\
\hline \multicolumn{7}{|c|}{ Panel B: Equal-Weighted Transactions and Value-Weighted Portfolios (EW-MVW) } \\
\hline Avg. Return & $\begin{array}{c}-1.963^{*} \\
(-1.82)\end{array}$ & $\begin{array}{c}-1.209^{*} \\
(-1.77)\end{array}$ & $\begin{array}{c}-0.852^{*} \\
(-1.98)\end{array}$ & $\begin{array}{c}-0.907^{*} \\
(-1.77)\end{array}$ & $\begin{array}{c}-0.684^{* *} \\
(-2.18)\end{array}$ & $\begin{array}{l}-0.304 \\
(-1.53)\end{array}$ \\
\hline CAPM Alpha & $\begin{array}{l}-1.970 \\
(-1.57)\end{array}$ & $\begin{array}{l}-1.193 \\
(-1.46)\end{array}$ & $\begin{array}{l}-0.786 \\
(-1.45)\end{array}$ & $\begin{array}{l}-0.834 \\
(-1.19)\end{array}$ & $\begin{array}{c}-0.614^{*} \\
(-1.71)\end{array}$ & $\begin{array}{l}-0.259 \\
(-1.39)\end{array}$ \\
\hline FF Alpha & $\begin{array}{l}-1.771 \\
(-1.51)\end{array}$ & $\begin{array}{l}-1.016 \\
(-1.35)\end{array}$ & $\begin{array}{l}-0.722 \\
(-1.36)\end{array}$ & $\begin{array}{l}-0.840 \\
(-1.20)\end{array}$ & $\begin{array}{l}-0.597 \\
(-1.66)\end{array}$ & $\begin{array}{l}-0.251 \\
(-1.37)\end{array}$ \\
\hline Carhart Alpha & $\begin{array}{l}-1.636 \\
(-1.42)\end{array}$ & $\begin{array}{l}-1.086 \\
(-1.54)\end{array}$ & $\begin{array}{l}-0.742 \\
(-1.59)\end{array}$ & $\begin{array}{l}-0.859 \\
(-1.25)\end{array}$ & $\begin{array}{c}-0.620^{*} \\
(-1.87)\end{array}$ & $\begin{array}{l}-0.259 \\
(-1.48)\end{array}$ \\
\hline 5-Factor Alpha & $\begin{array}{c}-2.306^{*} \\
(-1.78)\end{array}$ & $\begin{array}{c}-1.407^{*} \\
(-1.93)\end{array}$ & $\begin{array}{c}-0.952^{*} \\
(-1.93)\end{array}$ & $\begin{array}{c}-1.115^{*} \\
(-1.68)\end{array}$ & $\begin{array}{c}-0.779 * * \\
(-2.47)\end{array}$ & $\begin{array}{c}-0.385^{* *} \\
(-2.20)\end{array}$ \\
\hline \multicolumn{7}{|c|}{ Panel C: Value-Weighted Transactions and Equal-Weighted Portfolios (TW-MEW) } \\
\hline Avg. Return & $\begin{array}{c}-2.200^{* *} \\
(-2.33)\end{array}$ & $\begin{array}{c}-1.649^{* *} \\
(-2.28)\end{array}$ & $\begin{array}{l}-0.348 \\
(-0.74)\end{array}$ & $\begin{array}{l}-0.243 \\
(-0.48)\end{array}$ & $\begin{array}{l}-0.119 \\
(-0.31)\end{array}$ & $\begin{array}{l}-0.321 \\
(-0.88)\end{array}$ \\
\hline CAPM Alpha & $\begin{array}{c}-2.198^{* *} \\
(-2.23)\end{array}$ & $\begin{array}{c}-1.672^{* *} \\
(-2.33)\end{array}$ & $\begin{array}{l}-0.348 \\
(-0.70)\end{array}$ & $\begin{array}{l}-0.202 \\
(-0.37)\end{array}$ & $\begin{array}{l}-0.094 \\
(-0.26)\end{array}$ & $\begin{array}{l}-0.259 \\
(-0.91)\end{array}$ \\
\hline FF Alpha & $\begin{array}{c}-2.119^{* *} \\
(-2.16)\end{array}$ & $\begin{array}{c}-1.564^{* *} \\
(-2.31)\end{array}$ & $\begin{array}{l}-0.326 \\
(-0.64)\end{array}$ & $\begin{array}{l}-0.176 \\
(-0.34)\end{array}$ & $\begin{array}{l}-0.059 \\
(-0.16)\end{array}$ & $\begin{array}{l}-0.271 \\
(-0.96)\end{array}$ \\
\hline Carhart Alpha & $\begin{array}{c}-2.039^{* *} \\
(-2.12)\end{array}$ & $\begin{array}{c}-1.642^{* *} \\
(-2.54)\end{array}$ & $\begin{array}{l}-0.328 \\
(-0.65)\end{array}$ & $\begin{array}{l}-0.180 \\
(-0.35)\end{array}$ & $\begin{array}{l}-0.081 \\
(-0.23)\end{array}$ & $\begin{array}{l}-0.279 \\
(-0.98)\end{array}$ \\
\hline 5-Factor Alpha & $\begin{array}{c}-2.598^{* *} \\
(-2.31)\end{array}$ & $\begin{array}{c}-1.631^{* *} \\
(-2.44)\end{array}$ & $\begin{array}{l}-0.544 \\
(-1.02)\end{array}$ & $\begin{array}{l}-0.572 \\
(-1.16)\end{array}$ & $\begin{array}{l}-0.260 \\
(-0.73)\end{array}$ & $\begin{array}{c}-0.514^{*} \\
(-1.92)\end{array}$ \\
\hline \multicolumn{7}{|c|}{ Panel D: Value-Weighted Transactions and Value-Weighted Portfolios (TW-MVW) } \\
\hline Avg. Return & $\begin{array}{c}-2.782^{* *} \\
(-2.35)\end{array}$ & $\begin{array}{c}-1.989^{* *} \\
(-2.37)\end{array}$ & $\begin{array}{c}-1.051^{*} \\
(-1.68)\end{array}$ & $\begin{array}{l}-1.026 \\
(-1.59)\end{array}$ & $\begin{array}{c}-1.241^{* *} \\
(-2.41)\end{array}$ & $\begin{array}{l}-0.531 \\
(-1.29)\end{array}$ \\
\hline CAPM Alpha & $\begin{array}{c}-2.793^{* *} \\
(-2.10)\end{array}$ & $\begin{array}{c}-2.025^{* *} \\
(-2.09)\end{array}$ & $\begin{array}{l}-1.049 \\
(-1.44)\end{array}$ & $\begin{array}{l}-1.019 \\
(-1.31)\end{array}$ & $\begin{array}{c}-1.149^{* *} \\
(-2.10)\end{array}$ & $\begin{array}{l}-0.458 \\
(-1.37)\end{array}$ \\
\hline FF Alpha & $\begin{array}{c}-2.638^{* *} \\
(-2.04)\end{array}$ & $\begin{array}{c}-1.765^{* *} \\
(-2.12)\end{array}$ & $\begin{array}{l}-0.931 \\
(-1.39)\end{array}$ & $\begin{array}{l}-0.951 \\
(-1.29)\end{array}$ & $\begin{array}{c}-1.123^{* *} \\
(-2.09)\end{array}$ & $\begin{array}{l}-0.488 \\
(-1.46)\end{array}$ \\
\hline Carhart Alpha & $\begin{array}{c}-2.585^{*} \\
(-1.96)\end{array}$ & $\begin{array}{c}-1.827^{* *} \\
(-2.29)\end{array}$ & $\begin{array}{l}-0.949 \\
(-1.48)\end{array}$ & $\begin{array}{l}-0.985 \\
(-1.35)\end{array}$ & $\begin{array}{c}-1.171^{* *} \\
(-2.42)\end{array}$ & $\begin{array}{l}-0.497 \\
(-1.50)\end{array}$ \\
\hline 5-Factor Alpha & $\begin{array}{c}-3.180^{* *} \\
(-2.14)\end{array}$ & $\begin{array}{c}-2.237^{* * *} * \\
(-2.68)\end{array}$ & $\begin{array}{c}-1.318^{*} \\
(-1.93)\end{array}$ & $\begin{array}{c}-1.409 * * \\
(-2.07)\end{array}$ & $\begin{array}{c}-1.463^{* * *} \\
(-3.10)\end{array}$ & $\begin{array}{c}-0.661^{*} \\
(-1.89)\end{array}$ \\
\hline
\end{tabular}




\section{Table 3.9: Politicians' Portfolios (Excluding Trust Transactions)}

This table presents average monthly raw and risk-adjusted returns (alphas) in percentages over 2004M012011M12 on the buy-minus-sell portfolios from the transactions in NYSE/AMEX/NASDAQ common stocks that the politicians made except for the ones in their trusts. Transactions data is from Center for Responsive Politics, stock returns from CRSP, and five factors and risk-free rate from WRDS. Daily portfolio returns are calculated using four different weighting schemes under holding periods from 1 week to 12 months and compounded to monthly returns. Newey-West robust t-statistics (three lags) are in parenthesis. ${ }^{*},{ }^{*}, * * *$ denote 10,5 , and $1 \%$ significance levels.

\begin{tabular}{|c|c|c|c|c|c|c|}
\hline Holding Period (Months): & $1 / 4$ & 1 & 2 & 3 & 6 & 12 \\
\hline \multicolumn{7}{|c|}{ Panel A: Equal-Weighted Transactions and Equal-Weighted Portfolios (EW-MEW) } \\
\hline Avg. Return & $\begin{array}{c}2.310^{* * *} \\
(3.66)\end{array}$ & $\begin{array}{c}0.693^{* *} \\
(2.52)\end{array}$ & $\begin{array}{l}0.432^{*} \\
(1.76)\end{array}$ & $\begin{array}{l}0.249 \\
(1.11)\end{array}$ & $\begin{array}{l}-0.013 \\
(-0.07)\end{array}$ & $\begin{array}{l}-0.002 \\
(-0.02)\end{array}$ \\
\hline CAPM Alpha & $\begin{array}{c}2.452^{* * *} \\
(4.44)\end{array}$ & $\begin{array}{c}0.743^{* * *} \\
(3.24)\end{array}$ & $\begin{array}{c}0.451^{* *} \\
(2.14)\end{array}$ & $\begin{array}{l}0.262 \\
(1.25)\end{array}$ & $\begin{array}{l}-0.016 \\
(-0.11)\end{array}$ & $\begin{array}{l}-0.007 \\
(-0.06)\end{array}$ \\
\hline FF Alpha & $\begin{array}{c}2.355^{* * *} \\
(4.64)\end{array}$ & $\begin{array}{c}0.756^{* * *} \\
(3.18)\end{array}$ & $\begin{array}{c}0.488^{* *} \\
(2.42)\end{array}$ & $\begin{array}{l}0.314 \\
(1.56)\end{array}$ & $\begin{array}{l}0.013 \\
(0.09)\end{array}$ & $\begin{array}{l}-0.002 \\
(-0.02)\end{array}$ \\
\hline Carhart Alpha & $\begin{array}{c}2.353^{* * *} \\
(4.59)\end{array}$ & $\begin{array}{c}0.753^{* * *} \\
(3.14)\end{array}$ & $\begin{array}{c}0.479^{* *} \\
(2.32)\end{array}$ & $\begin{array}{l}0.304 \\
(1.47)\end{array}$ & $\begin{array}{l}0.002 \\
(0.02)\end{array}$ & $\begin{array}{l}-0.002 \\
(-0.02)\end{array}$ \\
\hline 5-Factor Alpha & $\begin{array}{c}2.384^{* * * *} \\
(4.22)\end{array}$ & $\begin{array}{c}0.764^{* * *} \\
(3.01) \\
\end{array}$ & $\begin{array}{c}0.485^{* *} \\
(2.39) \\
\end{array}$ & $\begin{array}{l}0.318 \\
(1.49)\end{array}$ & $\begin{array}{l}0.023 \\
(0.16) \\
\end{array}$ & $\begin{array}{l}0.016 \\
(0.13)\end{array}$ \\
\hline \multicolumn{7}{|c|}{ Panel B: Equal-Weighted Transactions and Value-Weighted Portfolios (EW-MVW) } \\
\hline Avg. Return & $\begin{array}{c}1.369^{* * *} \\
(3.17)\end{array}$ & $\begin{array}{l}0.320 \\
(1.42)\end{array}$ & $\begin{array}{l}0.186 \\
(1.13)\end{array}$ & $\begin{array}{l}0.148 \\
(0.93)\end{array}$ & $\begin{array}{l}0.047 \\
(0.40)\end{array}$ & $\begin{array}{l}-0.048 \\
(-0.53)\end{array}$ \\
\hline CAPM Alpha & $\begin{array}{c}1.431^{* * *} \\
(3.59)\end{array}$ & $\begin{array}{l}0.365 \\
(1.64)\end{array}$ & $\begin{array}{c}0.237^{*} \\
(1.78)\end{array}$ & $\begin{array}{l}0.193^{*} \\
(1.70)\end{array}$ & $\begin{array}{l}0.078 \\
(0.86)\end{array}$ & $\begin{array}{l}-0.036 \\
(-0.43)\end{array}$ \\
\hline FF Alpha & $\begin{array}{c}1.365^{* * *} \\
(3.79)\end{array}$ & $\begin{array}{c}0.362^{*} \\
(1.76)\end{array}$ & $\begin{array}{l}0.236^{*} \\
(1.92)\end{array}$ & $\begin{array}{l}0.203^{*} \\
(1.88)\end{array}$ & $\begin{array}{l}0.086 \\
(1.00)\end{array}$ & $\begin{array}{l}-0.036 \\
(-0.46)\end{array}$ \\
\hline Carhart Alpha & $\begin{array}{c}1.372^{* * *} \\
(3.94)\end{array}$ & $\begin{array}{l}0.362^{*} \\
(1.78)\end{array}$ & $\begin{array}{l}0.229 \\
(1.66)\end{array}$ & $\begin{array}{l}0.190 \\
(1.47)\end{array}$ & $\begin{array}{l}0.076 \\
(0.86)\end{array}$ & $\begin{array}{l}-0.042 \\
(-0.57)\end{array}$ \\
\hline 5-Factor Alpha & $\begin{array}{c}1.263^{* * *} \\
(3.33)\end{array}$ & $\begin{array}{l}0.326 \\
(1.46)\end{array}$ & $\begin{array}{l}0.185 \\
(1.17)\end{array}$ & $\begin{array}{l}0.183 \\
(1.21)\end{array}$ & $\begin{array}{l}0.068 \\
(0.71)\end{array}$ & $\begin{array}{l}-0.072 \\
(-0.94)\end{array}$ \\
\hline \multicolumn{7}{|c|}{ Panel C: Value-Weighted Transactions and Equal-Weighted Portfolios (TW-MEW) } \\
\hline Avg. Return & $\begin{array}{c}2.291^{* * *} \\
(3.48)\end{array}$ & $\begin{array}{c}0.688^{* *} \\
(2.52)\end{array}$ & $\begin{array}{c}0.385 \\
(1.51)\end{array}$ & $\begin{array}{l}0.197 \\
(0.86)\end{array}$ & $\begin{array}{l}-0.045 \\
(-0.25)\end{array}$ & $\begin{array}{l}-0.008 \\
(-0.06)\end{array}$ \\
\hline CAPM Alpha & $\begin{array}{c}2.454^{* * *} \\
(4.39)\end{array}$ & $\begin{array}{c}0.731^{* * *} \\
(3.14)\end{array}$ & $\begin{array}{c}0.397^{*} \\
(1.80)\end{array}$ & $\begin{array}{l}0.201 \\
(0.90)\end{array}$ & $\begin{array}{l}-0.057 \\
(-0.35)\end{array}$ & $\begin{array}{l}-0.019 \\
(-0.15)\end{array}$ \\
\hline FF Alpha & $\begin{array}{c}2.351^{* * *} \\
(4.56)\end{array}$ & $\begin{array}{c}0.739^{* * *} \\
(2.98)\end{array}$ & $\begin{array}{c}0.437^{* *} \\
(2.05)\end{array}$ & $\begin{array}{l}0.249 \\
(1.14)\end{array}$ & $\begin{array}{l}-0.032 \\
(-0.20)\end{array}$ & $\begin{array}{l}-0.014 \\
(-0.11)\end{array}$ \\
\hline Carhart Alpha & $\begin{array}{c}2.348^{* * *} \\
(4.49)\end{array}$ & $\begin{array}{c}0.735^{* * *} \\
(2.96)\end{array}$ & $\begin{array}{c}0.427^{*} \\
(1.97)\end{array}$ & $\begin{array}{l}0.240 \\
(1.10)\end{array}$ & $\begin{array}{l}-0.042 \\
(-0.27)\end{array}$ & $\begin{array}{l}-0.012 \\
(-0.10)\end{array}$ \\
\hline 5-Factor Alpha & $\begin{array}{c}2.377^{* * *} \\
(4.14)\end{array}$ & $\begin{array}{c}0.772^{* * *} \\
(3.00)\end{array}$ & $\begin{array}{c}0.444^{* *} \\
(2.14)\end{array}$ & $\begin{array}{l}0.259 \\
(1.17)\end{array}$ & $\begin{array}{l}-0.011 \\
(-0.07)\end{array}$ & $\begin{array}{l}0.018 \\
(0.13)\end{array}$ \\
\hline Panel D: Value-We & Transactic & is and Vali & -Weighte & Portfol & os (TW-1 & IVW) \\
\hline Avg. Return & $\begin{array}{l}0.777 \\
(1.29)\end{array}$ & $\begin{array}{l}0.011 \\
(0.03)\end{array}$ & $\begin{array}{l}-0.187 \\
(-0.55)\end{array}$ & $\begin{array}{l}-0.271 \\
(-0.85)\end{array}$ & $\begin{array}{l}-0.207 \\
(-0.82)\end{array}$ & $\begin{array}{l}-0.096 \\
(-0.58)\end{array}$ \\
\hline CAPM Alpha & $\begin{array}{l}0.814 \\
(1.49)\end{array}$ & $\begin{array}{l}0.015 \\
(0.05)\end{array}$ & $\begin{array}{l}-0.195 \\
(-0.59)\end{array}$ & $\begin{array}{l}-0.287 \\
(-0.93)\end{array}$ & $\begin{array}{l}-0.203 \\
(-0.83)\end{array}$ & $\begin{array}{l}-0.098 \\
(-0.63)\end{array}$ \\
\hline FF Alpha & $\begin{array}{l}0.857 \\
(1.52)\end{array}$ & $\begin{array}{l}0.068 \\
(0.21)\end{array}$ & $\begin{array}{l}-0.172 \\
(-0.51)\end{array}$ & $\begin{array}{l}-0.259 \\
(-0.81)\end{array}$ & $\begin{array}{l}-0.195 \\
(-0.78)\end{array}$ & $\begin{array}{l}-0.088 \\
(-0.58)\end{array}$ \\
\hline Carhart Alpha & $\begin{array}{c}0.841 \\
(1.43)\end{array}$ & $\begin{array}{c}0.051 \\
(0.15)\end{array}$ & $\begin{array}{l}-0.194 \\
(-0.56)\end{array}$ & $\begin{array}{l}-0.277 \\
(-0.86)\end{array}$ & $\begin{array}{l}-0.205 \\
(-0.83)\end{array}$ & $\begin{array}{l}-0.091 \\
(-0.60)\end{array}$ \\
\hline 5-Factor Alpha & $\begin{array}{c}0.787 \\
(1.23)\end{array}$ & $\begin{array}{c}0.164 \\
(0.42)\end{array}$ & $\begin{array}{l}-0.209 \\
(-0.59)\end{array}$ & $\begin{array}{l}-0.336 \\
(-0.99)\end{array}$ & $\begin{array}{l}-0.251 \\
(-0.98)\end{array}$ & $\begin{array}{l}-0.140 \\
(-0.86)\end{array}$ \\
\hline
\end{tabular}




\section{Table 3.10: Powerful Spouses}

This table presents average monthly raw and risk-adjusted returns (alphas) in percentages over 2004M012011M12 on the buy-minus-sell portfolios from the transactions in NYSE/AMEX/NASDAQ common stocks by the spouses of powerful politicians (i.e., powerful spouses). Transactions data is from Center for Responsive Politics, stock returns from CRSP, and five factors and risk-free rate from WRDS. Daily portfolio returns are calculated using four different weighting schemes under holding periods from 1 week to 12 months and compounded to monthly returns. Newey-West robust t-statistics (three lags) are in parenthesis.*, ${ }^{* *}, * * *$ denote 10,5 , and $1 \%$ significance levels.

\begin{tabular}{|c|c|c|c|c|c|c|}
\hline Holding Period (Months): & $1 / 4$ & 1 & 2 & 3 & 6 & 12 \\
\hline \multicolumn{7}{|c|}{ Panel A: Equal-Weighted Transactions and Equal-Weighted Portfolios (EW-MEW) } \\
\hline Avg. Return & $\begin{array}{l}1.264^{*} \\
(1.96)\end{array}$ & $\begin{array}{l}0.489 \\
(1.08)\end{array}$ & $\begin{array}{l}0.492 \\
(1.50)\end{array}$ & $\begin{array}{c}0.591^{* *} \\
(2.20)\end{array}$ & $\begin{array}{l}0.254 \\
(0.98)\end{array}$ & $\begin{array}{c}0.039 \\
(0.16)\end{array}$ \\
\hline CAPM Alpha & $\begin{array}{c}1.327^{* *} \\
(2.05)\end{array}$ & $\begin{array}{l}0.593^{*} \\
(1.84)\end{array}$ & $\begin{array}{c}0.581^{* *} \\
(2.53)\end{array}$ & $\begin{array}{c}0.670^{* * *} \\
(2.83)\end{array}$ & $\begin{array}{l}0.308 \\
(1.42)\end{array}$ & $\begin{array}{l}0.067 \\
(0.28)\end{array}$ \\
\hline FF Alpha & $\begin{array}{c}1.358^{* *} \\
(2.15)\end{array}$ & $\begin{array}{l}0.569^{*} \\
(1.77)\end{array}$ & $\begin{array}{c}0.583^{* *} \\
(2.51)\end{array}$ & $\begin{array}{c}0.651^{* * *} \\
(2.68)\end{array}$ & $\begin{array}{l}0.324 \\
(1.49)\end{array}$ & $\begin{array}{l}0.084 \\
(0.37)\end{array}$ \\
\hline Carhart Alpha & $\begin{array}{c}1.372^{* *} \\
(2.28)\end{array}$ & $\begin{array}{c}0.580^{*} \\
(1.76)\end{array}$ & $\begin{array}{c}0.584^{* *} \\
(2.52)\end{array}$ & $\begin{array}{c}0.651^{* * *} \\
(2.68)\end{array}$ & $\begin{array}{l}0.329 \\
(1.51)\end{array}$ & $\begin{array}{l}0.088 \\
(0.39)\end{array}$ \\
\hline 5-Factor Alpha & $\begin{array}{l}1.203^{*} \\
(1.89)\end{array}$ & $\begin{array}{l}0.338 \\
(0.95)\end{array}$ & $\begin{array}{c}0.513^{* *} \\
(2.13)\end{array}$ & $\begin{array}{c}0.646^{* *} \\
(2.56)\end{array}$ & $\begin{array}{l}0.371 \\
(1.66)\end{array}$ & $\begin{array}{l}0.065 \\
(0.26)\end{array}$ \\
\hline \multicolumn{7}{|c|}{ Panel B: Equal-Weighted Transactions and Value-Weighted Portfolios (EW-MVW) } \\
\hline Avg. Return & $\begin{array}{l}1.045^{*} \\
(1.72)\end{array}$ & $\begin{array}{c}0.746^{* * *} \\
(2.84)\end{array}$ & $\begin{array}{c}0.713^{* * *} \\
(3.36)\end{array}$ & $\begin{array}{c}0.485^{* * *} \\
(2.67)\end{array}$ & $\begin{array}{c}0.430^{* * *} \\
(2.72)\end{array}$ & $\begin{array}{l}0.171 \\
(1.05)\end{array}$ \\
\hline CAPM Alpha & $\begin{array}{l}1.079 \\
(1.66)\end{array}$ & $\begin{array}{c}0.777^{* * *} \\
(3.09)\end{array}$ & $\begin{array}{c}0.717^{* * *} \\
(3.94)\end{array}$ & $\begin{array}{c}0.487^{* * * *} \\
(2.88)\end{array}$ & $\begin{array}{c}0.435^{* * *} \\
(2.72)\end{array}$ & $\begin{array}{l}0.180 \\
(1.09)\end{array}$ \\
\hline FF Alpha & $\begin{array}{l}1.027 \\
(1.59)\end{array}$ & $\begin{array}{c}0.754^{* * *} \\
(3.17)\end{array}$ & $\begin{array}{c}0.723^{* * *} \\
(4.12)\end{array}$ & $\begin{array}{c}0.474 * * * \\
(2.89)\end{array}$ & $\begin{array}{c}0.422^{* * *} \\
(2.73)\end{array}$ & $\begin{array}{l}0.172 \\
(1.08)\end{array}$ \\
\hline Carhart Alpha & $\begin{array}{l}1.035 \\
(1.64)\end{array}$ & $\begin{array}{c}0.760^{* * * *} \\
(3.26)\end{array}$ & $\begin{array}{c}0.724^{* * *} \\
(4.13)\end{array}$ & $\begin{array}{c}0.469 * * * \\
(2.88)\end{array}$ & $\begin{array}{c}0.414^{* * *} \\
(2.73)\end{array}$ & $\begin{array}{l}0.168 \\
(1.06)\end{array}$ \\
\hline 5-Factor Alpha & $\begin{array}{l}1.030 \\
(1.54)\end{array}$ & $\begin{array}{c}0.701^{* * *} \\
(2.86)\end{array}$ & $\begin{array}{c}0.792^{* * *} \\
(3.87)\end{array}$ & $\begin{array}{c}0.562^{* * *} \\
(2.88)\end{array}$ & $\begin{array}{c}0.431^{* *} \\
(2.45)\end{array}$ & $\begin{array}{l}0.153 \\
(0.79)\end{array}$ \\
\hline \multicolumn{7}{|c|}{ Panel C: Value-Weighted Transactions and Equal-Weighted Portfolios (TW-MEW) } \\
\hline Avg. Return & $\begin{array}{l}1.186^{*} \\
(1.76)\end{array}$ & $\begin{array}{l}0.422 \\
(0.92)\end{array}$ & $\begin{array}{l}0.501 \\
(1.60)\end{array}$ & $\begin{array}{c}0.619^{* *} \\
(2.29)\end{array}$ & $\begin{array}{l}0.213 \\
(0.79)\end{array}$ & $\begin{array}{l}0.003 \\
(0.01)\end{array}$ \\
\hline CAPM Alpha & $\begin{array}{l}1.240^{*} \\
(1.79)\end{array}$ & $\begin{array}{l}0.526 \\
(1.65)\end{array}$ & $\begin{array}{c}0.580^{* * * *} \\
(2.68)\end{array}$ & $\begin{array}{c}0.696^{* * *} \\
(2.73)\end{array}$ & $\begin{array}{l}0.261 \\
(1.19)\end{array}$ & $\begin{array}{l}0.018 \\
(0.08)\end{array}$ \\
\hline FF Alpha & $\begin{array}{l}1.273^{*} \\
(1.88)\end{array}$ & $\begin{array}{l}0.511 \\
(1.62)\end{array}$ & $\begin{array}{c}0.572^{* *} \\
(2.63)\end{array}$ & $\begin{array}{c}0.667^{* * *} \\
(2.66)\end{array}$ & $\begin{array}{l}0.272 \\
(1.24)\end{array}$ & $\begin{array}{l}0.032 \\
(0.14)\end{array}$ \\
\hline Carhart Alpha & $\begin{array}{c}1.289^{* *} \\
(2.00)\end{array}$ & $\begin{array}{l}0.523 \\
(1.61)\end{array}$ & $\begin{array}{c}0.573^{* *} \\
(2.63)\end{array}$ & $\begin{array}{c}0.666^{* * *} \\
(2.65)\end{array}$ & $\begin{array}{l}0.279 \\
(1.29)\end{array}$ & $\begin{array}{l}0.037 \\
(0.16)\end{array}$ \\
\hline 5-Factor Alpha & $\begin{array}{l}1.103 \\
(1.62)\end{array}$ & $\begin{array}{l}0.254 \\
(0.74)\end{array}$ & $\begin{array}{c}0.516^{* *} \\
(2.29)\end{array}$ & $\begin{array}{c}0.660^{* *} \\
(2.56)\end{array}$ & $\begin{array}{l}0.336 \\
(1.56)\end{array}$ & $\begin{array}{l}0.025 \\
(0.10)\end{array}$ \\
\hline Panel D: Value-Weighte & d Transac & ions and $\mathrm{V}$ & lue-Weigh & ed Portfol & S $(\mathrm{TW}-\mathrm{M}$ & W) \\
\hline Avg. Return & $\begin{array}{c}1.641^{* *} \\
(2.49)\end{array}$ & $\begin{array}{c}0.713^{* *} \\
(2.11)\end{array}$ & $\begin{array}{l}0.614^{*} \\
(1.96)\end{array}$ & $\begin{array}{c}0.480^{* *} \\
(2.02)\end{array}$ & $\begin{array}{l}0.281 \\
(1.60)\end{array}$ & $\begin{array}{l}0.013 \\
(0.08)\end{array}$ \\
\hline CAPM Alpha & $\begin{array}{c}1.669^{* *} \\
(2.23)\end{array}$ & $\begin{array}{c}0.723^{* *} \\
(2.21)\end{array}$ & $\begin{array}{c}0.607^{* *} \\
(2.38)\end{array}$ & $\begin{array}{c}0.477^{* *} \\
(2.31)\end{array}$ & $\begin{array}{l}0.288 \\
(1.53)\end{array}$ & $\begin{array}{l}0.012 \\
(0.08)\end{array}$ \\
\hline FF Alpha & $\begin{array}{c}1.711^{* *} \\
(2.32)\end{array}$ & $\begin{array}{c}0.746^{* *} \\
(2.46)\end{array}$ & $\begin{array}{c}0.619^{* *} \\
(2.60)\end{array}$ & $\begin{array}{c}0.467^{* *} \\
(2.33)\end{array}$ & $\begin{array}{l}0.289 \\
(1.52)\end{array}$ & $\begin{array}{l}0.016 \\
(0.12)\end{array}$ \\
\hline Carhart Alpha & $\begin{array}{c}1.733^{* *} \\
(2.53)\end{array}$ & $\begin{array}{c}0.752^{* *} \\
(2.47)\end{array}$ & $\begin{array}{c}0.623^{* *} \\
(2.61)\end{array}$ & $\begin{array}{c}0.469^{* *} \\
(2.32)\end{array}$ & $\begin{array}{l}0.294 \\
(1.54)\end{array}$ & $\begin{array}{l}0.017 \\
(0.12)\end{array}$ \\
\hline 5-Factor Alpha & $\begin{array}{c}1.838^{* *} \\
(2.44)\end{array}$ & $\begin{array}{c}0.661^{* *} \\
(2.05)\end{array}$ & $\begin{array}{c}0.653^{* *} \\
(2.43)\end{array}$ & $\begin{array}{c}0.554^{* *} \\
(2.33)\end{array}$ & $\begin{array}{l}0.338 \\
(1.63)\end{array}$ & $\begin{array}{l}0.011 \\
(0.07)\end{array}$ \\
\hline
\end{tabular}




\section{Table 3.11: Nonpowerful Spouses}

This table presents average monthly raw and risk-adjusted returns (alphas) in percentages over 2004M012011M12 on the buy-minus-sell portfolios from the transactions in NYSE/AMEX/NASDAQ common stocks by the spouses of non-powerful politicians (i.e., non-powerful spouses). Transactions data is from Center for Responsive Politics, stock returns from CRSP, and five factors and risk-free rate from WRDS. Daily portfolio returns are calculated using four different weighting schemes under holding periods from 1 week to 12 months and compounded to monthly returns. Newey-West robust t-statistics (three lags) are in parenthesis. ${ }^{*}, * *, * * *$ denote 10,5 , and $1 \%$ significance levels.

\begin{tabular}{|c|c|c|c|c|c|c|}
\hline Holding Period (Months): & $1 / 4$ & 1 & 2 & 3 & 6 & 12 \\
\hline \multicolumn{7}{|c|}{ Panel A: Equal-Weighted Transactions and Equal-Weighted Portfolios (EW-MEW) } \\
\hline \multirow[t]{2}{*}{ Avg. Return } & -0.659 & -0.386 & 0.094 & -0.118 & -0.402 & 0.035 \\
\hline & $(-0.56)$ & $(-0.43)$ & $(0.13)$ & $(-0.18)$ & $(-0.76)$ & $(0.10)$ \\
\hline \multirow[t]{2}{*}{ CAPM Alpha } & -0.549 & -0.426 & 0.199 & -0.057 & -0.293 & 0.124 \\
\hline & $(-0.59)$ & $(-0.53)$ & $(0.26)$ & $(-0.09)$ & $(-0.60)$ & $(0.39)$ \\
\hline \multirow[t]{2}{*}{ FF Alpha } & -0.412 & -0.530 & 0.189 & -0.062 & -0.269 & 0.147 \\
\hline & $(-0.46)$ & $(-0.72)$ & $(0.25)$ & $(-0.10)$ & $(-0.55)$ & $(0.53)$ \\
\hline \multirow[t]{2}{*}{ Carhart Alpha } & -0.438 & -0.538 & 0.113 & -0.118 & -0.306 & 0.125 \\
\hline & $(-0.51)$ & $(-0.74)$ & $(0.18)$ & $(-0.21)$ & $(-0.65)$ & $(0.51)$ \\
\hline \multirow[t]{2}{*}{ 5-Factor Alpha } & -0.080 & -0.548 & -0.149 & -0.152 & -0.297 & 0.139 \\
\hline & $(-0.08)$ & $(-0.75)$ & $(-0.23)$ & $(-0.24)$ & $(-0.55)$ & $(0.54)$ \\
\hline \multicolumn{7}{|c|}{ Panel B: Equal-Weighted Transactions and Value-Weighted Portfolios (EW-MVW) } \\
\hline \multirow[t]{2}{*}{ Avg. Return } & -0.899 & -0.644 & -0.599 & -0.261 & -0.375 & -0.121 \\
\hline & $(-0.81)$ & $(-0.85)$ & $(-1.03)$ & $(-0.53)$ & $(-1.45)$ & $(-0.64)$ \\
\hline \multirow[t]{2}{*}{ CAPM Alpha } & -0.816 & -0.701 & -0.574 & -0.265 & -0.376 & -0.105 \\
\hline & $(-0.92)$ & $(-1.15)$ & $(-0.97)$ & $(-0.54)$ & $(-1.33)$ & $(-0.51)$ \\
\hline \multirow[t]{2}{*}{ FF Alpha } & -0.673 & -0.679 & -0.530 & -0.231 & -0.364 & -0.076 \\
\hline & $(-0.79)$ & $(-1.16)$ & $(-0.92)$ & $(-0.49)$ & $(-1.31)$ & $(-0.39)$ \\
\hline \multirow[t]{2}{*}{ Carhart Alpha } & -0.701 & -0.698 & -0.608 & -0.303 & $-0.392^{*}$ & -0.092 \\
\hline & $(-0.87)$ & $(-1.26)$ & $(-1.44)$ & $(-0.85)$ & $(-1.75)$ & $(-0.62)$ \\
\hline \multirow[t]{2}{*}{ 5-Factor Alpha } & -0.417 & -0.651 & -0.700 & -0.325 & $-0.406^{*}$ & -0.045 \\
\hline & $(-0.47)$ & $(-1.17)$ & $(-1.57)$ & $(-0.91)$ & $(-1.69)$ & $(-0.28)$ \\
\hline \multicolumn{7}{|c|}{ Panel C: Value-Weighted Transactions and Equal-Weighted Portfolios (TW-MEW) } \\
\hline \multirow[t]{2}{*}{ Avg. Return } & -0.483 & -0.500 & -0.076 & 0.014 & -0.333 & 0.123 \\
\hline & $(-0.40)$ & $(-0.54)$ & $(-0.10)$ & $(0.02)$ & $(-0.60)$ & $(0.34)$ \\
\hline \multirow[t]{2}{*}{ CAPM Alpha } & -0.363 & -0.535 & -0.010 & 0.025 & -0.249 & 0.195 \\
\hline & $(-0.37)$ & $(-0.66)$ & $(-0.01)$ & $(0.04)$ & $(-0.51)$ & $(0.58)$ \\
\hline \multirow[t]{2}{*}{ FF Alpha } & -0.261 & -0.628 & -0.005 & 0.034 & -0.218 & 0.216 \\
\hline & $(-0.28)$ & $(-0.85)$ & $(-0.01)$ & $(0.05)$ & $(-0.45)$ & $(0.76)$ \\
\hline \multirow[t]{2}{*}{ Carhart Alpha } & -0.290 & -0.639 & -0.089 & -0.029 & -0.253 & 0.198 \\
\hline & $(-0.32)$ & $(-0.88)$ & $(-0.14)$ & $(-0.05)$ & $(-0.54)$ & $(0.75)$ \\
\hline \multirow[t]{2}{*}{ 5-Factor Alpha } & 0.101 & -0.564 & -0.283 & -0.006 & -0.154 & 0.232 \\
\hline & $(0.10)$ & $(-0.76)$ & $(-0.42)$ & $(-0.01)$ & $(-0.30)$ & $(0.86)$ \\
\hline \multicolumn{7}{|c|}{ Panel D: Value-Weighted Transactions and Value-Weighted Portfolios (TW-MVW) } \\
\hline \multirow[t]{2}{*}{ Avg. Return } & $\begin{array}{l}-0.469 \\
\quad\end{array}$ & -0.243 & -0.090 & 0.194 & -0.043 & 0.039 \\
\hline & & $(-0.25)$ & $(-0$ & $(0.24)$ & & $(0.11)$ \\
\hline \multirow[t]{2}{*}{ CAPM Alpha } & -0.336 & -0.277 & -0.028 & 0.243 & -0.005 & 0.063 \\
\hline & $(-0.30)$ & $(-0.36)$ & $(-0.03)$ & $(0.36)$ & & $(0.18)$ \\
\hline \multirow[t]{2}{*}{ FF Alpha } & -0.180 & -0.391 & 0.017 & 0.247 & 0.038 & 0.083 \\
\hline & $(-0.17)$ & $(-0.51)$ & $\left(\Omega_{0}\right.$ & $(0.36)$ & $(0.07)$ & $(0.24)$ \\
\hline \multirow[t]{2}{*}{ Carhart Alpha } & -0.215 & -0.387 & -0.051 & 0.217 & 0.028 & 0.079 \\
\hline & $(-0.21)$ & $(-0.50)$ & $(-0$. & $(0.33)$ & $(0.05)$ & $(0.24)$ \\
\hline 5-Factor Alpha & 0.178 & -0.354 & -0.169 & 0.305 & 0.185 & 0.146 \\
\hline & $(0.16)$ & $(-0.43)$ & $(-0.22)$ & $(0.42)$ & $(0.34)$ & $(0.40)$ \\
\hline
\end{tabular}




\section{Table 3.12: Politicians' Paired Portfolios}

This table presents average monthly raw and risk-adjusted returns (alphas) in percentages over 2004M012011M12 on the buy-minus-sell portfolios from the transactions in NYSE/AMEX/NASDAQ common stocks by the politicians who also reported transactions for their spouses. Transactions data is from Center for Responsive Politics, stock returns from CRSP, and five factors and risk-free rate from WRDS. Daily portfolio returns are calculated using four different weighting schemes under holding periods from 1 week to 12 months and compounded to monthly returns. Newey-West robust t-statistics (three lags) are in parenthesis. ${ }^{*}, * *, * * *$ denote 10,5 , and $1 \%$ significance levels.

\begin{tabular}{|c|c|c|c|c|c|c|}
\hline Holding Period (Months): & $1 / 4$ & 1 & 2 & 3 & 6 & 12 \\
\hline \multicolumn{7}{|c|}{ Panel A: Equal-Weighted Transactions and Equal-Weighted Portfolios (EW-MEW) } \\
\hline \multirow[t]{2}{*}{ Avg. Return } & 1.283 & 0.384 & 0.318 & 0.247 & 0.012 & -0.073 \\
\hline & $(1.38)$ & $(0.85)$ & $(0.90)$ & $(0.88)$ & $(0.05)$ & $(-0.42)$ \\
\hline \multirow[t]{2}{*}{ CAPM Alpha } & 1.402 & 0.429 & 0.392 & 0.339 & 0.049 & -0.079 \\
\hline & $(1.50)$ & $(1.09)$ & $(1.18)$ & $(1.42)$ & $(0.23)$ & $(-0.46)$ \\
\hline \multirow[t]{2}{*}{ FF Alpha } & 1.328 & 0.501 & 0.448 & 0.374 & 0.077 & -0.073 \\
\hline & $(1.45)$ & $(1.32)$ & $(1.33)$ & $(1.50)$ & $(0.36)$ & $(-0.41)$ \\
\hline \multirow[t]{2}{*}{ Carhart Alpha } & 1.357 & 0.504 & 0.437 & 0.349 & 0.054 & -0.076 \\
\hline & $(1.58)$ & $(1.34)$ & $(1.24)$ & $(1.40)$ & $(0.26)$ & $(-0.41)$ \\
\hline \multirow[t]{2}{*}{ 5-Factor Alpha } & 1.513 & 0.605 & 0.426 & 0.339 & 0.103 & -0.074 \\
\hline & (1.62) & $(1.52)$ & $(1.17)$ & $(1.32)$ & $(0.48)$ & $(-0.38)$ \\
\hline \multicolumn{7}{|c|}{ Panel B: Equal-Weighted Transactions and Value-Weighted Portfolios (EW-MVW) } \\
\hline \multirow[t]{2}{*}{ Avg. Return } & 0.253 & 0.036 & 0.040 & -0.048 & -0.060 & -0.077 \\
\hline & $(0.38)$ & $(0.11)$ & $(0.16)$ & $(-0.20)$ & $(-0.34)$ & $(-0.54)$ \\
\hline \multirow[t]{2}{*}{ CAPM Alpha } & 0.281 & 0.053 & 0.088 & 0.019 & -0.016 & -0.055 \\
\hline & $(0.40)$ & $(0.14)$ & $(0.38)$ & $(0.10)$ & $(-0.09)$ & $(-0.36)$ \\
\hline \multirow[t]{2}{*}{ FF Alpha } & 0.259 & 0.093 & 0.137 & 0.064 & 0.013 & -0.047 \\
\hline & $(0.37)$ & $(0.25)$ & $(0.58)$ & $(0.33)$ & $(0.08)$ & $(-0.32)$ \\
\hline \multirow[t]{2}{*}{ Carhart Alpha } & 0.293 & 0.106 & 0.133 & 0.042 & -0.004 & -0.056 \\
\hline & $(0.46)$ & $(0.32)$ & $(0.56)$ & $(0.21)$ & $(-0.02)$ & $(-0.41)$ \\
\hline \multirow[t]{2}{*}{ 5-Factor Alpha } & 0.358 & 0.126 & 0.055 & -0.048 & -0.052 & -0.119 \\
\hline & $(0.54)$ & $(0.35)$ & $(0.21)$ & $(-0.22)$ & $(-0.31)$ & $(-0.84)$ \\
\hline \multicolumn{7}{|c|}{ Panel C: Value-Weighted Transactions and Equal-Weighted Portfolios (TW-MEW) } \\
\hline \multirow[t]{2}{*}{ Avg. Return } & 1.083 & 0.290 & 0.251 & 0.142 & -0.014 & -0.051 \\
\hline & $(1.13)$ & $(0.63)$ & $(0.69)$ & $(0.51)$ & $(-0.06)$ & $(-0.28)$ \\
\hline \multirow[t]{2}{*}{ CAPM Alpha } & 1.200 & 0.311 & 0.298 & 0.213 & 0.005 & -0.068 \\
\hline & $(1.27)$ & $(0.79)$ & $(0.84)$ & $(0.86)$ & $(0.02)$ & $(-0.36)$ \\
\hline \multirow[t]{2}{*}{ FF Alpha } & 1.111 & 0.372 & 0.357 & 0.248 & 0.028 & -0.063 \\
\hline & $(1.19)$ & $(0.95)$ & $(1.02)$ & $(0.97)$ & $(0.13)$ & $(-0.33)$ \\
\hline \multirow[t]{2}{*}{ Carhart Alpha } & 1.136 & 0.376 & 0.348 & 0.223 & 0.007 & -0.062 \\
\hline & $(1.28)$ & $(0.98)$ & $(0.95)$ & $(0.88)$ & $(0.03)$ & $(-0.32)$ \\
\hline \multirow[t]{2}{*}{ 5-Factor Alpha } & 1.352 & 0.516 & 0.330 & 0.198 & 0.057 & -0.050 \\
\hline & $(1.40)$ & $(1.25)$ & $(0.89)$ & $(0.76)$ & $(0.25)$ & $(-0.24)$ \\
\hline \multicolumn{7}{|c|}{ Panel D: Value-Weighted Transactions and Value-Weighted Portfolios (TW-MVW) } \\
\hline \multirow[t]{2}{*}{ Avg. Return } & 1.193 & 0.186 & -0.079 & 0.168 & -0.078 & -0.008 \\
\hline & $(1.41)$ & $(0.39)$ & $(-0.22)$ & $(0.56)$ & $(-0.31)$ & $(-0.04)$ \\
\hline \multirow[t]{2}{*}{ CAPM Alpha } & 1.325 & 0.112 & -0.159 & 0.133 & -0.088 & -0.022 \\
\hline & $(1.48)$ & $(0.23)$ & $(-0.41)$ & $(0.44)$ & $(-0.34)$ & $(-0.13)$ \\
\hline \multirow[t]{2}{*}{ FF Alpha } & 1.295 & 0.149 & -0.105 & 0.176 & -0.079 & -0.034 \\
\hline & $(1.44)$ & $(0.31)$ & $(-0.28)$ & $(0.60)$ & $(-0.31)$ & $(-0.20)$ \\
\hline \multirow[t]{2}{*}{ Carhart Alpha } & 1.321 & 0.163 & -0.094 & 0.170 & -0.096 & -0.036 \\
\hline & $(1.50)$ & $(0.37)$ & $(-0.26)$ & $(0.57)$ & $(-0.39)$ & $(-0.22)$ \\
\hline 5-Factor Alpha & $1.651^{*}$ & 0.216 & -0.273 & -0.054 & -0.247 & -0.138 \\
\hline & $(1.75)$ & $(0.43)$ & $(-0.68)$ & $(-0.16)$ & $(-0.87)$ & $(-0.75)$ \\
\hline
\end{tabular}




\section{Table 3.13: Spouses' Paired Portfolios (Spouses of Type II Politicians)}

This table presents average monthly raw and risk-adjusted returns (alphas) in percentages over 2004M012011M12 on the buy-minus-sell portfolios from the transactions in NYSE/AMEX/NASDAQ common stocks by the spouses of politicians who also reported transactions for themselves (Type II politicians). Transactions data is from Center for Responsive Politics, stock returns from CRSP, and five factors and risk-free rate from WRDS. Daily portfolio returns are calculated using four different weighting schemes under holding periods from 1 week to 12 months and compounded to monthly returns. Newey-West robust t-statistics (three lags) are in parenthesis.*, ${ }^{*},{ }^{* * *}$ denote 10,5 , and $1 \%$ significance levels.

\begin{tabular}{|c|c|c|c|c|c|c|}
\hline Holding Period (Months): & $1 / 4$ & 1 & 2 & 3 & 6 & 12 \\
\hline Panel A: Equal-Weigh & d Transa & tions and & qual-Weig & ted Portfo & ios $(\mathrm{EW}-\mathrm{M}$ & EW) \\
\hline Avg. Return & 0.543 & 0.610 & $0.723^{* *}$ & $0.594^{* *}$ & 0.068 & 0.070 \\
\hline & $(0.78)$ & $(1.18)$ & $(2.11)$ & $(2.10)$ & $(0.22)$ & $(0.28)$ \\
\hline CAPM Alpha & 0.578 & 0.636 & $0.755^{* * *}$ & $0.625^{* *}$ & 0.117 & 0.108 \\
\hline & $(0.93)$ & $(1.38)$ & $(2.91)$ & $(2.44)$ & $(0.45)$ & $(0.45)$ \\
\hline FF Alpha & 0.640 & 0.589 & $0.713^{* * *}$ & $0.593^{* *}$ & 0.141 & 0.122 \\
\hline & $(1.09)$ & $(1.44)$ & $(2.81)$ & $(2.2$ & $(0.54)$ & $(0.51)$ \\
\hline Carhart Alpha & 0.648 & 0.587 & $0.711^{* * *}$ & $0.596^{* *}$ & 0.137 & 0.125 \\
\hline & (1.11) & $(1.44)$ & $(2.80)$ & $(2$. & $(0.53)$ & $(0.53)$ \\
\hline 5-Factor Alpha & 0.335 & 0.547 & $0.666^{* *}$ & $0.601^{* *}$ & 0.176 & 0.118 \\
\hline & $(0.61)$ & $(1.21)$ & $(2.29)$ & $(2.07)$ & $(0.65)$ & $(0.45)$ \\
\hline Panel B: Equal-Weigh & d Trans: & tions and & alue-Weig & ted Portfo & os (EW-M & $\mathrm{JW})$ \\
\hline Avg. Return & $\begin{array}{l}1.245^{*} \\
(1.73)\end{array}$ & $\begin{array}{c}0.778^{* *} \\
(2.56)\end{array}$ & $\begin{array}{c}0.594^{* *} \\
(2.22)\end{array}$ & $\begin{array}{c}0.527^{* *} \\
(2.51)\end{array}$ & $\begin{array}{c}0.507^{* * *} \\
(2.99)\end{array}$ & $\begin{array}{c}0.282^{*} \\
(1.96)\end{array}$ \\
\hline CAPM Alpha & 1.268 & $0.809^{* * *}$ & $0.609^{* * *}$ & $0.536^{* * * *}$ & $0.517^{* * *}$ & $0.293^{*}$ \\
\hline FF Alpha & $1.285^{*}$ & $0.793^{* * *}$ & $0.613^{* * *}$ & $0.509^{* * *}$ & $0.504^{* * *}$ & $0.292^{* *}$ \\
\hline & $(1.84)$ & $(303)$ & $(269)$ & $(273)$ & & $(2.03)$ \\
\hline Carhart Alpha & $1.308^{* *}$ & $0.794^{* * *}$ & $0.609^{* * *}$ & $0.505^{* * *}$ & $0.498 * * *$ & $0.288^{* *}$ \\
\hline & $(2.01)$ & $(303)$ & $(269)$ & $(272)$ & $(3.03)$ & $(2.03)$ \\
\hline 5-Factor Alpha & $1.056^{*}$ & $0.703^{* *}$ & $0.595^{* *}$ & $0.544^{* *}$ & $0.541^{* * *}$ & $0.328^{* *}$ \\
\hline & $(1.87)$ & $(2.50)$ & $(2.22)$ & $(2.42)$ & $(2.87)$ & $(2.03)$ \\
\hline Panel C: Value- & d Transar & tions and & qual-Weig & ted Portfo & os (TW-M & $\mathrm{EW})$ \\
\hline Avg. Return & 0.518 & 0.495 & $0.681^{* *}$ & $0.603^{* *}$ & 0.045 & 0.066 \\
\hline & $(0.72)$ & & & $(2.1$ & $(0.14)$ & $(0.27)$ \\
\hline CAPM Alpha & 0.540 & 0.520 & $0.691^{* * *}$ & $0.615^{* *}$ & 0.074 & 0.087 \\
\hline & $(0.86)$ & & & & $(0.29)$ & $(0.37)$ \\
\hline FF Alpha & 0.605 & 83 & $0.644^{* * *}$ & $0.576^{* *}$ & 0.096 & 0.098 \\
\hline & $(1.01)$ & & & & $(0.37)$ & $(0.42)$ \\
\hline Carhart Alpha & 0.616 & 0.481 & $0.638^{* * *}$ & $0.576^{* *}$ & 0.096 & 0.105 \\
\hline & $(1.03)$ & & & & $(0.37)$ & $(0.45)$ \\
\hline 5-Factor Alpha & 0.344 & 0.452 & $0.643^{* *}$ & $0.600^{* *}$ & 0.163 & 0.114 \\
\hline & $(0.59)$ & $(1.01)$ & $(2.41)$ & $(2.08)$ & $(0.61)$ & $(0.46)$ \\
\hline Panel D: Val & d Transa & ons and & lue-Weig & ted Portfo & os (TW-M & JW) \\
\hline Avg. Return & $1.851^{* *}$ & 0.672 & 0.452 & $0.558^{* *}$ & $0.460^{* *}$ & 0.102 \\
\hline & & & & & & $(0.61)$ \\
\hline CAPM Alpha & $1.814^{*}$ & $0.656^{*}$ & 0.432 & $0.556^{* *}$ & $0.470 * * *$ & 0.103 \\
\hline & $(1.90)$ & & & & $(2.71)$ & $(0.67)$ \\
\hline FF Alpha & $1.887^{* *}$ & $0.661^{*}$ & 0.443 & $0.525^{* *}$ & $0.469 * * *$ & 0.113 \\
\hline & $(2.13)$ & & & & & $(0.75)$ \\
\hline Carhart Alpha & $1.925^{* *}$ & $0.665^{*}$ & 0.450 & $0.534^{* *}$ & $0.479 * * *$ & 0.117 \\
\hline & $(2.44)$ & & & & & $(0.76)$ \\
\hline 5-Factor Alpha & $1.831^{* *}$ & $\begin{array}{l}0.552 \\
(142)\end{array}$ & $\begin{array}{l}0.433 \\
(137)\end{array}$ & $0.585^{* *}$ & $0.567^{* * *}$ & 0.163 \\
\hline & $(2.41)$ & $(1.4$ & & & & $(1.01)$ \\
\hline
\end{tabular}




\section{Table 3.14: Spouses of Type III Politicians}

This table presents average monthly raw and risk-adjusted returns (alphas) in percentages over 2004M012011M12 on the buy-minus-sell portfolios from the transactions in NYSE/AMEX/NASDAQ common stocks by the spouses of politicians who did not report transactions for themselves (Type III politicians). Transactions data is from Center for Responsive Politics, stock returns from CRSP, and five factors and risk-free rate from WRDS. Daily portfolio returns are calculated using four different weighting schemes under holding periods from 1 week to 12 months and compounded to monthly returns. Newey-West robust t-statistics (three lags) are in parenthesis.*, ${ }^{*},{ }^{* * *}$ denote 10,5 , and $1 \%$ significance levels.

\begin{tabular}{|c|c|c|c|c|c|c|}
\hline Holding Period (Months): & $1 / 4$ & 1 & 2 & 3 & 6 & 12 \\
\hline \multicolumn{7}{|c|}{ Panel A: Equal-Weighted Transactions and Equal-Weighted Portfolios (EW-MEW) } \\
\hline \multirow[t]{2}{*}{ Avg. Return } & 0.854 & 0.091 & 0.244 & 0.299 & 0.177 & -0.005 \\
\hline & $(0.92)$ & $(0.14)$ & $(0.48)$ & $(0.69)$ & $(0.51)$ & $(-0.02)$ \\
\hline \multirow[t]{2}{*}{ CAPM Alpha } & 0.955 & 0.174 & 0.401 & 0.419 & 0.288 & 0.045 \\
\hline & $(1.07)$ & $(0.34)$ & $(1.02)$ & $(0.94)$ & $(1.00)$ & $(0.15)$ \\
\hline \multirow[t]{2}{*}{ FF Alpha } & 0.878 & 0.094 & 0.449 & 0.405 & 0.299 & 0.073 \\
\hline & $(1.00)$ & $(0.19)$ & $(1.22)$ & $(0.93)$ & $(1.05)$ & $(0.24)$ \\
\hline \multirow[t]{2}{*}{ Carhart Alpha } & 0.890 & 0.119 & 0.446 & 0.373 & 0.281 & 0.055 \\
\hline & (1.04) & $(0.23)$ & $(1.22)$ & $(0.97)$ & $(1.13)$ & $(0.22)$ \\
\hline \multirow[t]{2}{*}{ 5-Factor Alpha } & 1.272 & 0.006 & 0.436 & 0.483 & 0.358 & 0.122 \\
\hline & $(1.44)$ & $(0.01)$ & $(1.18)$ & $(1.14)$ & $(1.46)$ & $(0.48)$ \\
\hline \multicolumn{7}{|c|}{ Panel B: Equal-Weighted Transactions and Value-Weighted Portfolios (EW-MVW) } \\
\hline \multirow[t]{2}{*}{ Avg. Return } & 0.649 & 0.297 & 0.348 & $0.363^{* *}$ & 0.199 & 0.174 \\
\hline & $(0.81)$ & $(0.73)$ & (1.44) & $(2.01)$ & $(1.38)$ & $(1.50)$ \\
\hline \multirow[t]{2}{*}{ CAPM Alpha } & 0.554 & 0.257 & 0.336 & $0.352^{* *}$ & 0.199 & 0.165 \\
\hline & $(0.73)$ & $(0.70)$ & (1.50) & $(2.24)$ & $(1.33)$ & $(1.41)$ \\
\hline \multirow[t]{2}{*}{ FF Alpha } & 0.511 & 0.206 & 0.340 & $0.353^{* *}$ & 0.186 & 0.154 \\
\hline & $(0.66)$ & $(0.54)$ & (1.51) & $(2.26)$ & $(1.23)$ & $(1.33)$ \\
\hline \multirow[t]{2}{*}{ Carhart Alpha } & 0.530 & 0.209 & 0.345 & $0.345^{* *}$ & 0.169 & 0.143 \\
\hline & $(0.72)$ & $(0.54)$ & (1.54) & $(2.29)$ & $(1.28)$ & $(1.46)$ \\
\hline \multirow[t]{2}{*}{ 5-Factor Alpha } & 0.808 & 0.424 & $0.505^{* *}$ & $0.508^{* * *}$ & 0.186 & 0.150 \\
\hline & $(1.04)$ & $(1.15)$ & $(2.37)$ & $(3.64)$ & $(1.45)$ & $(1.54)$ \\
\hline \multicolumn{7}{|c|}{ Panel C: Value-Weighted Transactions and Equal-Weighted Portfolios (TW-MEW) } \\
\hline \multirow[t]{2}{*}{ Avg. Return } & 0.847 & 0.023 & 0.206 & 0.260 & 0.110 & -0.015 \\
\hline & $(0.87)$ & $(0.03)$ & $(0.42)$ & $(0.61)$ & $(0.33)$ & $(-0.05)$ \\
\hline \multirow[t]{2}{*}{ CAPM Alpha } & 0.942 & 0.093 & 0.351 & 0.380 & 0.221 & 0.025 \\
\hline & $(0.98)$ & $(0.18)$ & $(0.93)$ & $(0.86)$ & $(0.84)$ & $(0.08)$ \\
\hline \multirow[t]{2}{*}{ FF Alpha } & 0.853 & -0.008 & 0.382 & 0.359 & 0.220 & 0.048 \\
\hline & $(0.90)$ & $(-0.02)$ & (1.06) & $(0.83)$ & $(0.84)$ & $(0.15)$ \\
\hline \multirow[t]{2}{*}{ Carhart Alpha } & 0.864 & 0.021 & 0.382 & 0.329 & 0.204 & 0.031 \\
\hline & $(0.92)$ & $(0.04)$ & & & $(0.87)$ & $(0.12)$ \\
\hline \multirow[t]{2}{*}{ 5-Factor Alpha } & 1.208 & -0.100 & 0.384 & 0.477 & 0.322 & 0.102 \\
\hline & $(1.27)$ & $(-0.17)$ & $(1.04)$ & $(1.16)$ & $(1.38)$ & $(0.37)$ \\
\hline \multicolumn{7}{|c|}{ Panel D: Value-Weighted Transactions and Value-Weighted Portfolios (TW-MVW) } \\
\hline \multirow[t]{2}{*}{ Avg. Return } & 0.108 & -0.166 & 0.262 & 0.254 & -0.028 & 0.249 \\
\hline & $(0.11)$ & $(-0.30)$ & $(0.66)$ & $(0.80)$ & $(-0.11)$ & $(1.19)$ \\
\hline \multirow[t]{2}{*}{ CAPM Alpha } & 0.022 & -0.162 & 0.281 & 0.270 & -0.027 & 0.233 \\
\hline & $(0.02)$ & $(-0.29)$ & $(0.69)$ & $(0.87)$ & $(-0.10)$ & $(1.03)$ \\
\hline \multirow[t]{2}{*}{ FF Alpha } & 0.002 & -0.201 & 0.322 & 0.300 & -0.018 & 0.234 \\
\hline & $(0.00)$ & $(-0.37)$ & $(0.81)$ & $(0.98)$ & $(-0.07)$ & $(1.06)$ \\
\hline \multirow[t]{2}{*}{ Carhart Alpha } & 0.023 & -0.186 & 0.325 & 0.292 & -0.027 & 0.222 \\
\hline & $(0.03)$ & $(-0.34)$ & $(0.82)$ & $(0.98)$ & $(-0.10)$ & $(1.10)$ \\
\hline 5-Factor Alpha & 0.292 & -0.135 & 0.456 & $0.478^{*}$ & 0.018 & 0.221 \\
\hline & $(0.32)$ & $(-0.24)$ & $(1.23)$ & $(1.75)$ & $(0.07)$ & $(1.09)$ \\
\hline
\end{tabular}




\section{Chapter 4}

\section{Aggregate Congressional Trading and Stock Market Returns}

\subsection{Introduction}

The STOCK Act makes it clear that if members of Congress use nonpublic information to gain an unfair advantage in the market, then they are breaking the law. It creates new disclosure requirements and new measures of accountability and transparency for thousands of federal employees. That is a good and necessary thing. We were sent here to serve the American people and look out for their interests - not to look out for our own interests.

President Barack Obama, April 4, 2012. ${ }^{1}$

Allegations of congressional insider trading have held public attention for a long time. The American public became aware of the extent to which politicians reaped personal benefits using information gained from their official positions thanks to an influential academic study undertaken by Ziobrowski et al. (2004). They demonstrated that members of the U.S. Senate beat the market for the 1993-1998 period. The frustration with Congress over insider

\footnotetext{
${ }^{1}$ http://www.whitehouse.gov/blog/2012/04/04/president-obama-signs-stock-act
} 
trading spiked after Schweizer (2011) provided anecdotal evidence that politicians traded on nonpublic information and sometimes used their power to influence legislation that could favorably affect their personal finances. Public pressure on Congress reached its climax after a highly influential episode of 60 Minutes exposed congressional trading in great detail. ${ }^{2}$

Capitol Hill was not completely silent about the insider trading allegations. Representatives Brian Baird and Louise M. Slaughter introduced the Stop Trading on Congressional Knowledge (STOCK) Act to prevent politicians from trading on material nonpublic information in 2006. It would take six years to see the STOCK Act officially signed by the President on April 4, 2012. Public pressure played an important role in forcing Congress to enact the STOCK Act, which was seen as an opportunity to rebuild public trust for Congress by the bill's main sponsors (See Slaughter, 2011).

Even though there is now evidence to suggest that members of Congress may have been trading on material nonpublic information, we do not know enough about the information content of congressional stock trades. This paper sheds light on this issue by attempting to answer the following question: Does aggregate congressional trading predict future stock market returns over the 2004M01-2010M12 period? The term aggregate congressional trading refers to the transactions by the members of the U.S. House, Senate and Executive Branch (i.e. politicians).

We find that aggregate congressional trading predicts excess market returns two to three months in advance. This finding suggests that politicians, similar to corporate insiders, trade on information that has macroeconomic components and their stock trades contain economy-wide information regarding the future states of the economy. Our results still hold when we aggregate congressional stock trades at twelve different industry levels. We

\footnotetext{
${ }^{2}$ http://www.cbsnews.com/video/watch/?id=7388130n
} 
provide evidence that the members of the U.S. Senate do not trade on macroeconomic information, while the members of the U.S. House do. Transactions (trades) by the members of the Democratic and Republican parties both predict market returns, but the evidence for possessing macroeconomic information is stronger for Democrats.

We contribute to the literature in several ways. First, to the best of our knowledge, this paper is the first empirical study examining the relationship between aggregate congressional trading and stock market returns. Second, we help bridge the gap between the insider trading literature and political investment (or congressional trading) literature. Corporate insiders have two distinctive properties: they earn abnormal returns on their transactions, and their aggregate transactions predict stock market returns (Seyhun, 1988; Cohen et al., 2012). The previous literature shows that politicians earn abnormal returns on their stock trades (Ziobrowski et al., 2004), and our study documents that their transactions predict market returns. For example, Seyhun (1988) finds that one standard deviation in aggregate insider trading activity predicts a $1.7 \%$ increase in future excess market returns. Similarly, we document that one standard deviation change in congressional trading activity is associated with a $1.18 \%$ to $1.57 \%$ increase in future excess market returns. Thus, we add to this existing knowledge by showing that politicians resemble corporate insiders in that they beat the market and their transactions have predictive ability. This conclusion also helps to support the argument that politicians are not just politicians, they are also informed traders. Finally, we recommend policy changes on the disclosure requirements of the congressional stock trades in the STOCK Act.

The rest of the paper proceeds as follows. Section 2 briefly provides the legal framework and motivation behind the STOCK Act. Section 3 reviews the literature and introduces the hypotheses. Section 4 describes the data cleaning process, the data and how we construct our aggregate congressional trading measure. Section 5 outlines the empirical analysis and 
presents the results. Section 6 provides the subgroup analysis at the chamber and party levels. Section 7 introduces an alternative measure of aggregate congressional trading as a robustness check, and Section 8 concludes the paper and provides policy recommendations.

\subsection{Legal Framework and the STOCK Act}

In this section, we review expert opinions on the legal status of congressional trading from witnesses at congressional testimonies preceding the enactment of the STOCK Act. This act was first introduced by Representatives Brian Baird and Louise M. Slaughter in 2006. Slaughter (2011) argues that passing the STOCK Act can help Congress reverse its extremely low approval rate $(6 \%)$ and send a strong signal to the public that Congress is interested in addressing their concerns.

Khuzami (2011), as the Director of Enforcement at the Securities and Exchange Commission (SEC), clarifies that members of Congress and their staffers are not exempt from insider trading laws whose legal framework is based on the Section 10(b) and Rule of 10b-5 of the SEC Act of 1934. However, he emphasizes that the enforcement of insider trading violations on members of Congress may be challenging due to the lack of any precedent. He argues that "Congressional staff, as employees, owe a duty of trust and confidence to their employer" based on the case law and they are subject to the insider trading laws in case they breach this duty by using material nonpublic information gleaned from their work for personal gains. On the other hand, such a duty is ambiguous for members of Congress since "there does not appear to be any case law that addresses the duty of a Member with respect to trading on the basis of information he or she learns in an official capacity." Therefore, he suggests that any law or amendment to existing laws should clearly state that members of Congress have a duty of trust and confidence that prohibits them from trading on material nonpublic information. 
Nagy (2011) firmly states that insider trading by members of Congress is not legal since "congressional insider trading in securities violates the broad anti-fraud provisions in federal securities law as well as the federal mail and wire fraud statutes." She proposes an amendment to the existing law such that members of Congress and federal employees owe a duty of trust and confidence when they obtain material nonpublic information at their job. Similar to Khuzami (2011), she argues that Congress does not have to pass a new law explicitly banning congressional insider trading. There seems to be a consensus among the enforcement authorities and legal scholars of insider trading laws that the STOCK Act was not really necessary and the same goal could be accomplished by amending the existing laws.

The STOCK Act brings sweeping changes to the way members of Congress, the Executive Branch, and their staff trade and report their transactions. Section 3 of the STOCK Act bans members and employees of Congress from using nonpublic information that they obtain in the process of performing their official duties. Section 4 of the STOCK Act explicitly states that members and employees of Congress are subject to the insider trading laws. Prior to the STOCK Act, politicians were required to report their transactions by May 15th of each year for the previous calendar year and these transactions would become public in the paper (not online) with a further one month delay. Sections 6 and 8 of the STOCK Act require these transactions to be reported no later than 30 days after members of Congress are notified of such transactions, but definitely no later than 45 days after they take place. Some politicians state that they do not actually follow which stocks are bought or sold in their accounts because their brokers handle their investments. By emphasizing the word "notified", these sections of the law ensure that politicians keep track of their transactions irrespective of who executes them. There are also similar restrictions and regulations for employees and members of the Executive Branch. ${ }^{3}$

\footnotetext{
${ }^{3}$ The 2013 amendment of the STOCK Act abolished the online posting requirement due to national security and identity theft concerns, and instead it allowed members of Congress to post their transactions
} 
The STOCK Act does not take any action against so-called political intelligence firms except for requiring an official study examining the extent and influence of political intelligence activities. Furthermore, Section 14 of the STOCK Act provides an exception to "widely held investment fund (whether such fund is a mutual fund, regulated investment company, pension or deferred compensation plan, or other investment fund), if (1)(A) the

fund is publicly traded; or (B) the assets of the fund are widely diversified; and (2) the reporting individual neither exercises control over nor has the ability to exercise control over the financial interests held by the fund." "The STOCK Act also requires the transactions by politicians to be available online for the public to easily search. The Clerk of the House has been publishing the financial disclosure reports of the members of the U.S. House online since 2008 as a requirement under the Honest Leadership and Open Government Act of 2007 (Section 304). Nevertheless, the information content of these publications is very shallow since they only report the filing date of these reports, but not the content of them. Therefore, this act is not comparable to the STOCK Act in its scope.

\subsection{Literature Review and Hypothesis Development}

\subsubsection{Politicians and Stock Returns: Political Investment}

Ziobrowski et al. (2004) provide evidence that members of the U.S. Senate earn abnormal returns in their common stock investments (85 basis points a month) for the 1993-1998 period. Their empirical setup uses transaction-based calendar-time portfolios and assumes a fixed one-year holding period. In a separate study, Ziobrowski et al. (2011) document that members of the U.S. House outperform the market by a significant margin ( 55 basis points

in electronically locked files (inaccessible to public) at their own discretion. It also restricted the coverage of the STOCK Act to the members of Congress by exempting the federal workers from complying with the requirements of this act.

${ }^{4}$ http://thomas.loc.gov/cgi-bin/query/z?c112:S.2038: 
a month) for the 1985-2001 period. Their research has generated a great deal of interest and has stimulated campaigns to stop politicians from trading on material nonpublic information.

Eggers and Hainmueller (2013a, 2013b) investigate the abnormal returns for the U.S. House and Senate for the 2004-2008 period in two different studies. They do not find evidence in favor of abnormal returns on the common stock portfolios of politicians. However, they document a local bias in politicians' investments such that the share of local companies (i.e. companies headquartered in their district or state) in politicians' portfolios is thirteen times more than that of other companies. By using pooled OLS with clustered standard errors by month, they show that a portfolio of these local investments indeed outperforms the market by approximately $3.00 \%$ on annual basis. Overall, their results suggest that politicians have an informational advantage at the local scale, not at the market scale. The recent studies by Karadas (2014a) and Karadas (2014b) present evidence that members of Congress are informed traders trading on time-sensitive information, and they share some of their private information with their spouses. Nevertheless, the scope of these studies is limited to the investigation of the firm-specific information in congressional stock trades.

There are also studies investigating the influence of politicians on stock returns. Gao and Huang (2011) find that politically connected hedge funds beat the market by $1.5 \%$ to $1.6 \%$ on a monthly basis, which indicates the pervasiveness of information-gathering efforts by hedge funds. Political connections may not only provide private information but may also help companies influence a legislation process in their favor. Cooper et al. (2010) document a strong relationship between a firm's contribution to political campaigns and abnormal returns on its stock prices in the subsequent periods. Goldman et al. (2009) show that the appointment of someone who has strong connections with politicians to the board of directors in a firm has a positive impact on stock prices. Faccio and Parsley (2009) provide evidence that firms headquartered in a politician's hometown experience abnormal positive 
returns when he or she takes office and suffer a negative shock when he or she dies.

\subsubsection{Corporate Insiders and Market Returns}

Seyhun (1988) documents a positive correlation between aggregate insider trading in a given month and two consecutive periods of market returns. Seyhun (1992) investigates why aggregate insider trading predicts future market returns by comparing two competing explanations, the cash-flows and fads hypotheses. According to the cash-flows hypothesis, corporate insiders are better positioned to predict their firms' future cash-flows and they trade on this unique advantage before anyone else. Their prediction can be based on firm-specific news or macroeconomic conditions. To the extent that their prediction of future cash-flows is based on the future macroeconomic conditions, aggregate insider trading predicts future market returns. Seyhun (1992) lends support to the cash-flow hypothesis by showing that current aggregate insider trading is highly correlated with the growth rates of industrial production, gross national product and after-tax corporate profits.

Lakonishok and Lee (2001) also document that aggregate insider trading is positively related to future stock market returns, but find smaller results after controlling for contrarian trading by insiders. Jiang and Zaman (2010) provide more rigorous evidence to the cash-

flows hypothesis by disentangling the unexpected cash-flow and unexpected discount rate news from the realized market returns via a VAR decomposition process that uses (1) excess market returns, (2) term yield, (3) S\&P 500 earnings growth, and (4) small value spread as the state variables. They document that the ability of corporate insiders to predict future market returns is strongly related to their ability to predict future cash-flow news.

\subsubsection{Hypothesis Development}

Our theoretical framework rests on the synthesis between the insider trading literature and the political investment literature. Such a synthesis requires us to address three key issues: 
(i) the relationship between aggregate insider trading by corporate insiders and stock market returns; (ii) the comparison of politicians and corporate insiders; and (iii) the relationship between aggregate congressional trading and stock market returns.

There is strong empirical support from the insider trading literature that corporate insiders can recognize the deviations of their companies' stock prices from fundamentals (i.e. mispricing) and trade profitably by exploiting them (see Lakonishok and Lee, 2001). There are two main reasons for such mispricing to occur (see Seyhun, 1988; Chowdhury et al., 1993; Jiang and Zaman, 2010). The first reason is that noise traders push stock prices away from their fundamental values and cause mispricing. If there is an economy-wide noise diverting stock prices from fundamentals and corporate insiders react to it, we expect a negative relation between future aggregate insider trading and past stock market returns.

The mispricing of stocks can also occur due to changes in cash-flows that are not observed yet by outsiders (ordinary investors and analysts). Corporate insiders have an advantage over outsiders in predicting their firms' cash-flows due to their day-to-day involvement with firms' operations. As a result, they can assess whether the current stock price reflects their own valuation based on the fundamentals that are not completely captured by outsiders and trade on any mispricing they observe. When corporate insiders recognize changes in their future cash flows, they may not necessarily know whether these changes are motivated by firm-specific or macroeconomic information (see Seyhun, 1988). The following example illustrates how insider trading can be related to stock returns under these two different information types.

Suppose that the CEO of a construction materials company recognizes that there is a growing demand for their products in the market and thus anticipates higher future cashflows. At the same time, he observes that the stock price of the company does not reflect the 
trend in the market and decides to purchase shares. If the growing demand for the company's products and higher future cash-flows are caused only by firm-specific factors such as better product design or marketing, then we do not expect any relationship between insider trading and stock market returns. On the other hand, if the change in future cash-flows is motivated (at least partially) by economy-wide factors such as an increase in the demand for housing, we then expect a relationship between insider trading and stock market returns. To the extent that cash-flow changes take place as a result of economy-wide factors, we expect a positive relationship between past aggregate insider trading and future stock market returns (see Seyhun, 1988; 1992).

The second issue we need to address is how politicians compare to corporate insiders. Politicians are not insiders in a sense that they do not have the information possessed by corporate insiders to do an accurate cash-flow analysis that could enable them to spot any mispricing of stocks. Nevertheless, politicians are likely to have information that has the potential to affect a company's stock price and cash-flows. Furthermore, it is quite unlikely for politicians to recognize economy-wide noise in stock prices, which arises in the absence of new information. Therefore, we argue that politicians are overall more likely to trade on new information than past stock returns.

The third issue to address is the relationship between aggregate congressional trading and market returns. As Eggers and Hainmueller (2013b) point out, politicians are in close contact with the firms headquartered in their districts or states and they can collect useful information about the state of the economy from these firms. We argue that firms headquartered elsewhere can also provide a politician with an outlook on the state of the economy as long as they operate in a politician's district or state. Furthermore, politicians are aware of upcoming or pending legislation that is not public yet. Some of this legislation may contain either only firm-specific information such as regulations targeting specific firms or 
information with economy-wide components such as bail-outs.

Politicians also exchange information with their lobbyists and campaign contributors that in the past has led to the growth of the political intelligence industry at Capitol Hill. Politicians are likely to take some cues about the economy from these exchanges. It is also likely that politicians may interpret publicly available data differently based on what they already know. For example, a reported increase in the growth rate of GDP in a postrecession period is clearly good news and ordinary investors are likely to react positively. However, a politician attuned to economic affairs may interpret this piece of news as a temporary improvement based on how he or she thinks the economy will do in the long-run. In conclusion, we argue that some congressional trades are driven (at least partially) by macroeconomic information, and most of this information comes from firms that politicians routinely interact with. Therefore, we expect that as an aggregate opinion of politicians, aggregate congressional trading is positively related to stock market returns with aggregate congressional trading predicting stock market returns.

\subsubsection{Research Question and Hypotheses}

Our research question is whether aggregate congressional trading predicts future excess stock market returns over the 2004M01-2010M12 period. Based on the synthesis between the insider trading and political investment literatures, we test the following hypotheses:

Null Hypothesis: There is no relationship between past aggregate congressional trading and future excess market returns.

Alternative Hypothesis: There is a statistically significant positive relationship between past aggregate congressional trading and future excess market returns.

Politicians have information regarding the future state of the economy (i.e. macroeco- 
nomic information). They are also likely to have knowledge concerning how the firms they are in close contact with will be affected by particular macroeconomic events. We hypothesize that politicians identify and trade on such macroeconomic information ahead of other market participants. Therefore, similar to Seyhun (1988), we anticipate that lagged values of aggregate congressional trading are positively related to future excess market returns. Due to this anticipation, we employ one-tailed t-test in testing our hypotheses. We hope to reject the null hypothesis in favor of the alternative hypothesis.

\subsection{Data and Aggregate Congressional Trading}

\subsubsection{Raw Data}

The transactions data used in this study cover the 2004-2010 period and come from the Center for Responsive Politics (CRP). CRP extracts these data from the Financial Disclosure Reports (FDR) filed by politicians. All members of the U.S. House of the Representatives and their employees with the pay grade above GS-15 need to file a FDR. When they file, they must include transactions made by their spouse and dependent children. Their financial transactions need to be declared in the FDR if the transaction exceeds $\$ 1,000$. Members of the U.S. Senate and the Executive Branch are also subject to similar disclosure requirements.

The data cover all of the FDRs by incumbent members of the U.S. House, Senate, and Executive Branch, their spouses and dependent children over the 2004-2010 period. ${ }^{5}$ Transactions in the FDRs are specified as buy, or sell, or exchange with the dates (day/month/year) that they take place. The FDRs (hence the raw dataset) do not provide security identifiers, which could enable users to collect more information on individual securities such as secu-

\footnotetext{
${ }^{5}$ Freshman politicians file their first FDRs in their first year in the office for the previous calendar year during which they were not in Congress. These pre-election transactions account for only $6 \%$ of the observations in the "clean" (final) dataset. These transactions actually bias our results towards finding an insignificant relationship between aggregate congressional trading and future stock returns. Therefore, we keep them in the final sample to add more robustness to our estimations.
} 
rity types, prices and returns. Therefore, we match asset names in the transactions with company names from the Center for Research in Security Prices (CRSP). The matching process takes a significant amount of time and effort due to the inconsistencies in the way that asset names are written in the FDRs (e.g. General Motors, Genrl Motors, etc.). However, we painstakingly check the accuracy of each match and ensure that every asset in the final sample has a permanent security identifier PERMNO.

Another critical issue with the FDRs is that they do not specify the number of shares bought or sold on a transaction or the share price at which a transaction is executed. Instead, they provide a dollar amount of a transaction within intervals. Some of these intervals are $\$ 0-\$ 1,000, \$ 1001-\$ 15,000$, and $\$ 15,001-\$ 50,000$ with the upper limit going up to $\$ 50,000,001$. However, there are some transactions reported with the exact dollar amount. We use the exact dollar amount whenever it is available. When it is unavailable, we take the midpoint of a given interval and assume that this point represents the dollar amount of the transaction (see Ziobrowski et al., 2004).

Due to the matching process and filters that we impose, transactions falling under one or more of the following categories are dropped: (1) missing transaction date or amount, (2) transaction amounts less than $\$ 100$, (3) duplicates, (4) exchanges of shares (e.g. mergers and acquisitions), (5) transactions specified as both purchase and sell, (6) real assets (e.g. land), (7) options, treasury securities, corporate bonds and certificate of deposits, (8) neither ordinary common shares nor American Depository Receipts, and (9) asset names that are not listed in CRSP. As a result of these filters, the number of transactions drops from 166,916 to 77,663 with 38,383 buy and 39,280 sell transactions. 


\subsubsection{Data Description}

Table 4.1 summarizes security types involved in the 77,663 transactions in our final dataset. All of the transactions in Table 4.1 represent either ordinary common shares or American Depository Receipts (ADRs). The largest category (81.21\%) is the transactions involving the U.S. common stocks (share code 10 and 11). The second (10.99\%) and third (5.73\%) largest categories are ADRs and ordinary common shares of companies incorporated outside the U.S., respectively. Ziobrowski et al. (2004) only keep the observations with share code 10 and 11 in their study. Excluding the rest of the share codes would cost us 14,597 transactions. Therefore, we keep all of the share codes in Table 4.1. There are 3,503 stocks (i.e. PERMNOs) in our final sample, $78.05 \%$ of which are U.S. common stocks.

\section{[Table 4.1 About Here]}

Table 4.2 summarizes the characteristics of transactions. Most of the transactions in both buy and sell samples are less than or equal to $\$ 15,000$. The highest number of buy transactions took place in 2010 and the highest number of sell transactions occurred in 2006. Furthermore, the number of sell transactions was greater than that of buy transactions for 2004, 2005, 2006, and 2007. In 2008, 2009 and 2010, there were more buy transactions than sell transactions. These numbers suggest that politicians were more engaged in selling stocks than buying stocks in the run-up to the Great Recession of 2008-2009. Table 4.3 lists all-time top ten traders in the buy and sell samples. The top nine traders in both samples are the same people but their ranks change. Transactions in the sell sample seem to be more evenly distributed than those in the buy sample, in which Michael McCaul carried out $14.82 \%$ of the transactions.

\section{[Table 4.2 About Here]}

\section{[Table 4.3 About Here]}

In the beginning, we had 723 politicians in our data set. However, the filters we imposed 
on the raw data reduced this number to 433 with the following distribution: 88 senators, 321 representatives, and 24 executive branch members and 183 democrats, 247 republicans, and 3 independents.

Table 4.4 shows the breakdown of the transactions in the final dataset by the chamber and party affiliations. Over the sample period, Senators and Representatives have 19,645 (223.24) and 57,813 (180.10) transactions in total (on average), respectively. Democrats and Republicans have 28,376 (155.06) and 49,120 (198.87) transactions in total (on average) over the same period, respectively.

\section{[Table 4.4 About Here]}

\subsubsection{Measure of Aggregate Congressional Trading}

Following Jiang and Zaman (2010), we create a person-based trading index (PTI) to capture aggregate congressional trading in three steps. First, for every firm-month (e.g. June 2010 for IBM, July 2010 for IBM, etc.), we calculate the total number of politicians buying and selling (hereafter total buyers and total sellers, respectively) a company's shares. Next, we subtract the total sellers from the total buyers and divide this difference by the sum of the total buyers and the total sellers for every firm-month. In the last step, we average the firm-month level series from the earlier step over the number of companies in a given month. The formula for PTI:

$$
\mathrm{PTI}_{t}=\frac{\sum_{k=1}^{N} \frac{\text { TBuyer }_{t, k}-\text { TSeller }_{t, k}}{\text { TBuyer }_{t, k}+\text { TSeller }_{t, k}}}{N}
$$

where TBuyer $_{t, k}$ and TSeller $_{t, k}$ are the total number of buyers and sellers, respectively, in

firm $k$ and month $t$, which starts at January 2004 and ends at December 2010, spanning a total of 84 months. $N$ is the number of firms in month $t$. This method does not take into consideration the frequency of trades by a politician in a firm in a given month. For example, a politician may have bought General Motors shares ten times in March of 2010, but PTI 
will only assign a value of 1 for all of these transactions since they are carried out by the same person. By focusing on the number of people trading a company's shares instead of the number of times the shares of a company is bought or sold, PTI prevents more active traders from skewing the results. ${ }^{6}$

\subsection{Empirical Analysis and Results}

We now investigate the ability of our person-based trading index (PTI) to predict future excess market returns on the equal-weighted market index $(E R E W)$ and on the valueweighted market index $(E R V W)$. We obtain the equal- and value-weighted market returns and one-month T-bill rate from CRSP. We compute excess returns as 100 times the difference between the raw market returns and one-month T-bill rate. One key difference between equal and value-weighted returns is that CRSP excludes American Depository Receipts (ADRs) in the construction of the value-weighted market index while it keeps them in the construction of the equal-weighted market index. Due to this methodical difference, we define a full sample and a limited sample. The full (limited) sample includes all transactions (all transactions except for ADRs) in the entire sample or in a given subgroup such as the Senate. As a result, when the dependent variable is $E R E W(E R V W)$, we use the transactions in the full (limited) sample to construct PTI.

Our empirical strategy involves three steps. First, we estimate a baseline model by using only the past values of PTI as our independent variables. Second, we control for macroeconomic variables that the past literature documented to be related to market returns. We use default spread, term spread and earnings price ratio as the set of macroeconomic variables and explain how they are constructed in Section 5.3. Third, we compute PTI at the 12 Fama-French industry levels and use the past values of PTI along with the past

\footnotetext{
${ }^{6}$ We also calculate $P T I$ based on the number of transactions instead of number of politicians. Our results are robust to the way we calculate PTI, which are available from the author upon request.
} 
industry returns as the independent variables. Such a specification also allows us to control for the correlation between future and past stock returns.

\subsubsection{Descriptive Statistics of Variables}

We report the descriptive statistics of the variables employed in the regression analysis in Table 4.5 over the $2004-2010$ period. The average excess return on the equal-weighted market index $(E R E W)$ is $0.64 \%$ a month and $7.68 \%$ a year while the average excess return on the value-weighted market index $(E R V W)$ is $0.37 \%$ a month and $4.44 \%$ a year. The average default spread, term spread and earnings price ratio are $1.19 \%, 1.84 \%$ and -0.66 , respectively.

\section{[Table 4.5 About Here]}

PTI has a mean value of -0.012 and a standard deviation of 0.157 . There is no statistically significant contemporaneous correlation between PTI and the excess market returns. Figure 1 depicts the values of PTI based on the full and limited sample over the 2004-2010 period. PTI reaches its lowest value (-0.51) in August of 2007 and its highest value (0.36) in December of 2010. PTI also appears to be a stationary series. The autocorrelation between PTI and its first 5 lags is 0.094, -0.038, 0.132, 0.037, and 0.077, respectively, all of which are statistically insignificant.

\subsubsection{Baseline Regression}

We estimate a functional form following Seyhun (1988) with the heteroskedasticity and autocorrelation (HAC) robust t-statistics over the 2004-2010 period ${ }^{7}$ :

$$
E R E W_{t}\left(E R V W_{t}\right)=\beta_{0}+\beta_{1} P T I_{t-1}+\beta_{2} P T I_{t-2}+\beta_{3} P T I_{t-3}+\varepsilon_{t}
$$

\footnotetext{
${ }^{7}$ We also estimate Eq. (2) without correcting for heteroskedasticity and autocorrelation. We obtain very similar results, which are available from the authors upon request.
} 
where $E R E W_{t}\left(E R V W_{t}\right)=r_{m t}-r_{f t} . r_{m t}$ is the return either on the CRSP equal-weighted market index or on the CRSP value-weighted market index in month $t$, and $r_{f t}$ is the risk-free rate in month $t$ proxied by the one-month T-bill rate.

Panel A and B in Table 4.6 provide the estimation results based on the transactions from all politicians in Congress and the Executive Branch for the baseline model. Panel A (B) summarizes the regression results when the dependent variable is the excess returns on the CRSP equal (value)-weighted market index, EREW (ERVW). In order to construct PTI, we use 38,383 (34,302) buy and 39,280 (34,823) sell transactions in Panel A (B). We use one-tailed t-test for the coefficients of $P T I_{t-1}, P T I_{t-2}$, and $P T I_{t-3}$ due to their anticipated positive signs. On the other hand, we use two-tailed t-test for the rest of the variables.

\section{[Table 4.6 About Here]}

In Panel $\mathrm{A}$, the intercept and coefficient of $P T I_{t-1}$ are statistically insignificant. On the other hand, the coefficients of $P T I_{t-2}$ and $P T I_{t-3}$ are statistically significant at the conventional levels even when they are both included in the same regression in Model IV. Furthermore, their signs are positive as we expected. The statistical significance of $P T I_{t-2}$ and $P T I_{t-3}$ is also accompanied by economic significance. For example, in Model IV in Panel A, one standard deviation increase in $P T I_{t-2}$ is associated with a $1.18 \%$ increase in the monthly excess returns at time $t$. Similarly, one standard deviation increase in $P T I_{t-3}$ is associated with a $1.57 \%$ increase in the monthly excess returns at time $t$. Panel B provides very similar results to those in Panel $\mathrm{A}$. In both panels, the adjusted $R^{2}$ stays below $8 \%$.

The positive coefficients of $P T I_{t-2}$ and $P T I_{t-3}$ in Panel $\mathrm{A}$ and $\mathrm{B}$ are consistent with the idea that politicians correctly anticipate macroeconomic changes that will affect stock returns two to three months in advance. When other market participants become aware of 
these macroeconomic changes, they push stock prices to levels anticipated by politicians. As a result, similar to what Seyhun (1988) documents for corporate insiders, the past aggregate trades by politicians predict future excess market returns. The statistically and economically insignificant coefficient of $P T I_{t-1}$ suggests that politicians invest in the stocks that are affected earliest by the anticipated macroeconomic changes, and the relationship between their past trading activity and future excess market returns takes longer than a month to emerge.

\subsubsection{Macroeconomic Variables}

We now investigate whether PTI still predicts excess market returns after controlling for macroeconomic variables known to be related to the market returns. We keep $P T I_{t-2}$ and $P T I_{t-3}$ in our model, but exclude $P T I_{t-1}$ since it does not predict excess market returns. We also experiment with other lags and find that only the second and/or third lag predicts excess market returns. As a result, we estimate the following equation with the HAC robust t-statistics:

$E R E W_{t}\left(E R V W_{t}\right)=\beta_{0}+\beta_{1} P T I_{t-2}+\beta_{2} P T I_{t-3}+\beta_{3} D$ Spread $_{t}+\beta_{4} T$ Spread $_{t}+\beta_{5} E P$ Ratio $_{t}+\varepsilon_{t}$

where DSpread, TSpread, and EP_Ratio are default spread, term spread and earnings price ratio. We subtract the rate on 3-month T-bill from the yield on 10-year Treasury bond in order to calculate TSpread. We follow Welch and Goyal (2007) to compute DSpread and EP_Ratio. We construct DSpread as the difference between the yield on BAA rated corporate debt and the yield on AAA rated corporate debt. For EP_Ratio, we first calculate the 12 month moving sum of the S\&P 500 earnings. Next, we subtract log price from log earnings. We obtain the necessary data for DSpread and TSpread from the Federal Reserve Bank of St. Louis and for EP_Ratio from Robert Shiller's website. 
Panel C and D in Table 4.6 summarize the regression results when the dependent variable is EREW and ERVW, respectively. We construct PTI in Panel C (D) the same way as we do in Panel A (B). In both panels, the coefficients of the default and term premiums are always statistically insignificant at the conventional levels. However, the earnings price ratio is statistically significant even when we estimate the model with all of the independent variables in Model $\mathrm{V}$. The coefficients of $P T I_{t-2}$ and $P T I_{t-3}$ are statistically significant at the $5 \%$ level in all of the models except in Model IV in Panel D where $P T I_{t-3}$ is statistically significant only at the $10 \%$ level. $^{8}$

\subsubsection{Industry-Level Returns}

In this section, we investigate whether our person-based trading index $(P T I)$ predicts excess returns at the industry-level by following the methodology in Howe et al. (2009). They present evidence that aggregate recommendations by analysts predict excess returns at the market and industry level. Based on a sample size exceeding 350,000 observations, they aggregate analyst recommendations at the 48 industries following the Fama-French (1997) classification and estimate pooled and Fama-MacBeth (1973) type regressions. We use all of the 77,663 transactions in our sample. Since our sample size is about one-fifth of that in Howe et al. (2009), we aggregate congressional trading at the 12 industry groups instead of 48 groups.

In the pooled regression, we control for 12 industry fixed-effects and calculate t-statistics robust to correlation within industries (clusters). In the Fama-MacBeth (1973) type regression, we first estimate time series regression for each industry and then test whether the

\footnotetext{
${ }^{8}$ We also check whether PTI takes away the significance that the macroeconomic variables would otherwise have. We first estimate a model with only macroeconomic variables and then add $P T I_{t-2}$ and $P T I_{t-3}$. We repeat this procedure for equal- and value-weighted returns. The default and term premium do not predict excess market returns with and without PTI. On the other hand, the statistical significance of earnings price ratio slightly improves after including $P T I_{t-2}$ and $P T I_{t-3}$ in the regression. For both equaland value-weighted returns, the adjusted $R^{2}$ more than doubles after including $P T I_{t-2}$ and $P T I_{t-3}$. These findings suggest that PTI adds independent information to our models. The results are available from the author upon request.
} 
average coefficients from these time series regressions are statistically significantly different from zero. Since the second step in the Fama-MacBeth regression uses two-tailed t-test, we also use two-tailed t-test in the pooled regression in order to maintain consistency. For both types of regressions, we estimate the following equation:

$\operatorname{EREWIP} P_{i, t}\left(\operatorname{ERVWIP_{i,t}}\right)=\beta_{0}+\sum_{j=1}^{3} \beta_{j} P T I_{i, t-j}+\sum_{j=1}^{3} \theta_{j} E R E W I P_{i, t-j}\left(E R V W I P_{i, t-j}\right)+\varepsilon_{i, t}$

where $E R E W I P_{i, t}\left(E R V W I P_{i, t}\right)$ is the excess returns at time $t$ on the equal (value)-weighted industry portfolio $i$. We add industry dummies to this equation in the pooled regression. The econometric specification in Eq. (4) also helps us control for the ability of the past stock returns to predict the future stock returns.

\section{[Table 4.7 About Here]}

We summarize the results of the industry-level analysis in Table 4.7. Panel A reports the estimation results from the pooled regression with the industry-clustered t-statistics. When the dependent variable is EREWIP, the coefficients of $P T I_{t-2}$ and $P T I_{t-3}$ are statistically significant at the $5 \%$ and $10 \%$ level, respectively. When the dependent variable is $E R V W I P$, $P T I_{t-3}$ loses its predictive ability, but $P T I_{t-2}$ gains additional predictive power with its coefficient statistically significant at the $1 \%$ level. Irrespective of the choice for dependent variables, the past values of the dependent variable and all of the industry-dummies have statistically significant coefficients. Overall, the model with EREWIP as the dependent variable performs better with higher $R^{2}$.

Panel B summarizes the estimation results from the second step of the Fama-MacBeth (1973) type regression. In the first step, the past values of PTI predict excess returns in eight (four) out of twelve industries when the dependent variable is $E R E W I P(E R V W I P)$. 
Irrespective of the dependent variable, there is not a statistically significant relationship between industry-level PTI and excess returns for the following industries: Durable Goods, Manufacturing, and Chemicals. In Panel $\mathrm{B}$, the coefficients of $P T I_{t-2}$ and $P T I_{t-3}$ are statistically significant at the $1 \%$ and $5 \%$ level, respectively when the dependent variable is EREWIP. However, when the dependent variable is $E R V W I P$, only $P T I_{t-2}$ predicts excess returns. Similar to the results in Panel A, the past values of PTI performs better when the dependent variable is the excess returns on the equal-weighted portfolios.

Lakonishok and Lee (2001) document that "aggregate insider trading activity is more informative in predicting returns of smaller companies relative to large companies." Given that small companies have a larger impact on equal-weighted returns than on value-weighted returns, we argue that the better performance of PTI in explaining excess returns on equalweighted portfolios compared to value-weighted portfolios can be explained by the firm size factor documented by Lakonishok and Lee (2001).

\subsection{Subgroup Analysis: Chambers and Parties}

Ziobrowski et al. (2004) conduct subgroup analysis among senators by separately investigating the performance of common stock investments of members of the Democratic Party and Republican Party in the U.S. Senate. They find that Democrats have superior performance to Republicans in terms of market-adjusted returns, but the difference is not statistically significant. Ziobrowski et al. (2011) examine the abnormal returns from the transactions of the U.S. House and report lower but still statistically significant abnormal returns compared to the U.S. Senate. They also present evidence that the portfolios of Democrats seem to outperform those of Republicans. Based on these studies, we carry out a subgroup analysis by estimating Eq. (3) at the U.S. House, U.S. Senate, Democratic Party and Republican Party level, respectively. Since the first lag of PTI does not explain the excess market returns, we 
exclude it in the subgroup analysis. We do not carry out a separate analysis on aggregate trading by members of the Executive Branch because there are only 205 transactions from this group over the 2004-2010 period.

\section{House versus Senate}

Table 4.8 reports the regression results when the subgroup is the U.S. House (Panel A and B) and the U.S. Senate (Panel C and D), respectively. The coefficients of $P T I_{t-2}$ and $P T I_{t-3}$ are still statistically significant even when we restrict our sample to the transactions from the U.S. House. However, the statistical significance gets weaker in Panel B where $P T I_{t-3}$ is statistically significant only at the $10 \%$ level. On the other hand, there is not a significant relationship between the future excess market returns and the past values of PTI when the sample is only composed of transactions from the U.S. Senate as reported in Panel C and D. Furthermore, the coefficients of $P T I_{t-2}$ and $P T I_{t-3}$ in Panel $\mathrm{C}$ and $\mathrm{D}$ are in magnitude less than one third of those in Panel A and B. These results suggest that only Representatives trade on information with macroeconomic components. We remind readers that the number of transactions from the House is about three times the number of transactions from the Senate (see Table 4.4). Therefore, it is possible that the results in Panel C and D may have been driven by the smaller sample size.

[Table 4.8 About Here]

\section{Democrats versus Republicans}

Table 4.9 presents the regression results when the subgroup is Democrats (Panel A and B) and Republicans (Panel $\mathrm{C}$ and $\mathrm{D}$ ), respectively. In Panel A and B, $P T I_{t-2}$ consistently predicts the future excess market returns. However, $P T I_{t-3}$ has the persistent predictive ability only in Model V. In Panel $\mathrm{C}$ and $\mathrm{D}, P T I_{t-3}$ predicts the excess market returns in 
all but one model, but $P T I_{t-2}$ does not have any predictive ability. Overall, these results suggest that aggregate trading by Democrats and Republicans still predict excess market returns, but the evidence is stronger for Democrats than Republicans and for EREW than ERVW.

\section{[Table 4.9 About Here]}

\subsection{Robustness Check}

We use an alternative measure to capture aggregate congressional trading and test whether previous results hold under a different index. Seyhun (1988) develops a standardized measure to capture both the firm-level and economy-wide insider trading. We slightly modify his methodology to construct a transaction-based trading index (TTI) from congressional stock trades. We construct TTI in two steps. First, we find the total number of buy and sell transactions (hereafter total buys and total sells, respectively) in every month. Next, we subtract the total sells from the total buys and divide this difference by the sum of the total buys and the total sells on a monthly basis such that:

$$
T T I_{t}=\frac{P_{t}-S_{t}}{P_{t}+S_{t}}
$$

where $P_{t}$ and $S_{t}$ are the total buys and the total sells in month $t$, respectively. $t$ starts at January 2004 and ends at December 2010 spanning a total of 84 months. TTI has a mean of -0.012 and standard deviation of 0.169 . The minimum and maximum values it takes are -0.448 and 0.427 . Compared to PTI, TTI has the same mean but slightly higher standard deviation. These two indexes move in the same direction most of the time with a correlation coefficient of 0.84 .

[Table 4.10 About Here] 
Table 4.10 reports the coefficient estimates when we replace PTI with TTI. In Panel A and $\mathrm{B}$, we present the results from estimating the baseline model in Eq. (2) while Panel C and $\mathrm{D}$ show the coefficient estimates after controlling for macroeconomic variables. $T T I_{t-2}$ consistently predicts the future excess market returns. $T T I_{t-3}$ also has the predictive ability, but not as much as $T T I_{t-2}$. The results in Table 4.10 are very similar to those in Table 4.6 except that t-statistics associated with PTI are higher than those associated with TTI. Furthermore, the coefficients of $T T I_{t-2}$ and $T T I_{t-3}$ are also economically significant. One standard deviation increase in $T T I_{t-2}$ and $T T I_{t-3}$ is associated with $1.27 \%$ and $1.52 \%$ increase in the future monthly excess returns based on Model IV in Panel A. Overall, these results suggest that our findings are robust to different measures of aggregate congressional trading.

\subsection{Conclusion and Policy Implications}

This study investigates the ability of congressional stock trades to predict market returns. We provide evidence that aggregate congressional trading predicts excess market returns two to three months in advance using 77,663 stock transactions over the 2004-2010 period. This finding implies that politicians, similar to corporate insiders, trade on information containing macroeconomic components. Our subsample analysis reveals that the transactions by the members of the House and the Democratic Party seem to have more economy-wide information than those by the members of the Senate and the Republican Party.

Under the current provisions of the STOCK Act of 2012 and its 2013 amendment, it takes 60 to 75 days for congressional stock trades to be publicly available in paper. We suggest that Congress amend the STOCK Act to reduce this reporting lag and reinstate the online posting requirement so that investors can potentially use aggregate congressional trading as a leading indicator of economic performance and a market timing tool. Further- 
more, ordinary investors can mitigate the harmful effects of political uncertainty by following aggregate congressional trading since they are not likely to have access to political intelligence firms, which provide their clients with insider information from Capitol Hill. We argue that Congress can alleviate identity theft and national security concerns by assigning anonymous identifications to members of Congress. Investigating the source of predictive ability of aggregate congressional trading is an area that we hope that future research sheds light on. 


\section{Table 4.1: Types of Securities in the Final Sample}

This table presents the security types involved in all transactions by politicians (members of the U.S. House, Senate and Executive Branch) over the 2004-2010 period. We obtain share codes from CRSP that designate the type of a security. When the share code's first digit equals 1, it denotes ordinary common shares. When its first digit equals 3 , then it denotes American Depository Receipts. Accordingly, 10 and 11 represent the domestic common stocks. 12 represents the ordinary common shares of companies incorporated outside the U.S. 14, 15, and 18 represent ordinary common shares of closed-end funds, closed-end funds incorporated outside the U.S. and the real investment trusts (REIT), respectively.

Raw Data Source: Center for Responsive Politics (CRP)

\begin{tabular}{ccccc}
\hline \hline Share Code & No. of Transactions & Percent (\%) & No. of Stocks & Percent (\%) \\
\hline \hline 10 & 21 & 0.03 & 8 & 0.23 \\
11 & 63,045 & 81.18 & 2,734 & 78.05 \\
12 & 4,448 & 5.73 & 228 & 6.51 \\
14 & 604 & 0.78 & 113 & 3.23 \\
15 & 21 & 0.03 & 1 & 0.03 \\
18 & 986 & 1.27 & 112 & 3.20 \\
30 & 428 & 0.55 & 12 & 0.34 \\
31 & 8,110 & 10.44 & 295 & 8.42 \\
\hline \hline Total & 77,663 & 100 & 3,503 & 100 \\
\hline \hline
\end{tabular}


Figure 4.1: Person-Based Trading Index (PTI)

\section{Person-Based Trading Index (PTI)}

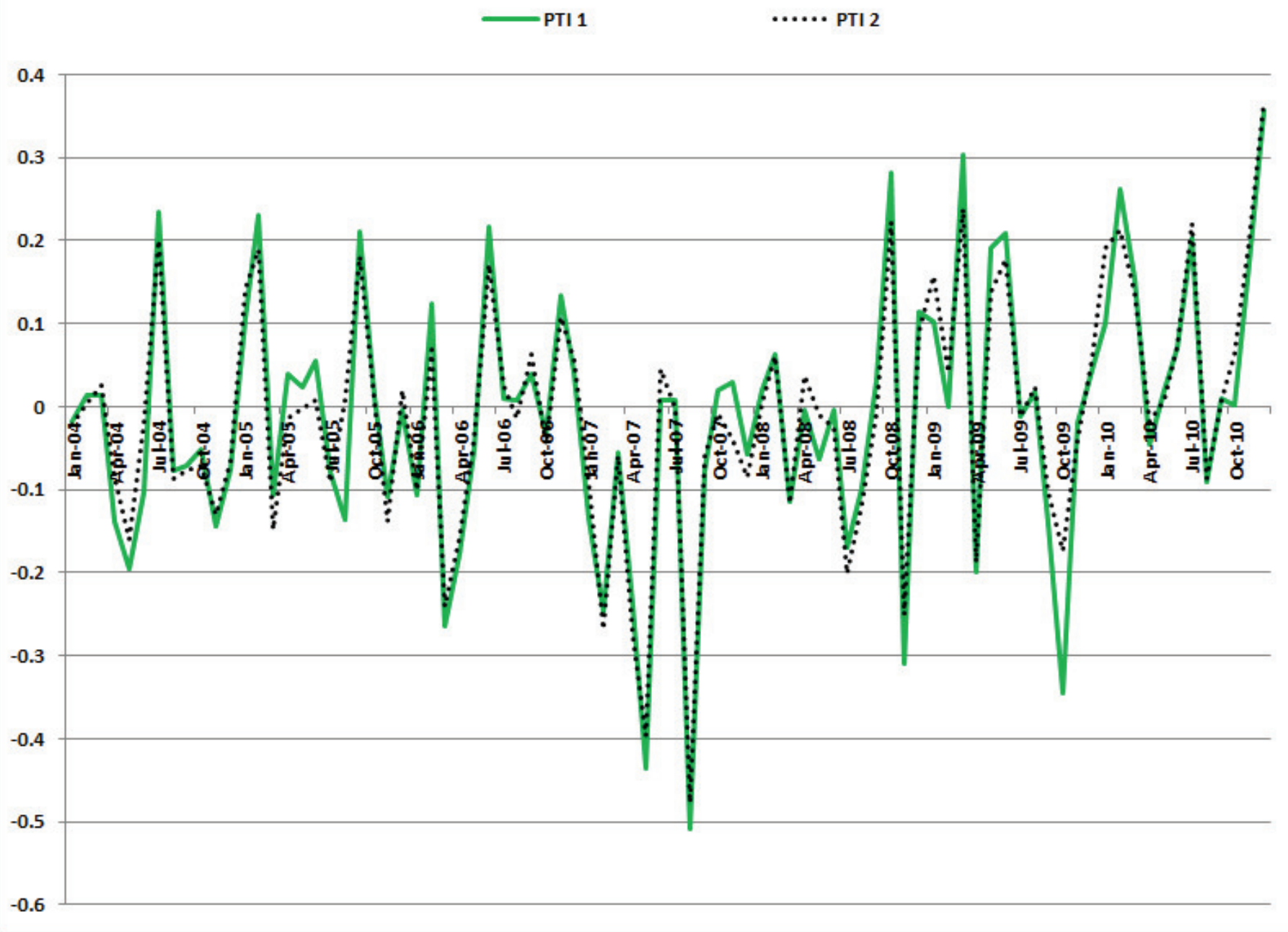

Figure 1: This figure illustrates the time series movement of person-based trading Index (PTI), which we construct by Eq. (1) using congressional stock transactions (trades) that took place over the 2004-2010 period. PTI1 takes into account all trades (full sample) while PTI2 excludes trades representing American Depository Receipts (limited sample). We obtain the transactions data from Center for Responsive Politics (CRP), available at http://www.opensecrets.org/index.php. 


\section{Table 4.2: Dollar Amounts of Transactions by Politicians}

This table provides information on the dollar amounts of transactions by politicians (members of the U.S. House, Senate and Executive Branch) over the 2004-2010 period. Panel A presents the number of buy transactions at different intervals as well as the total number of buy transactions for each year in the sample period. Similarly, Panel B shows the number of sell transactions at different intervals as well as the total number of sell transactions for each year in the sample period.

Raw Data Source: Center for Responsive Politics (CRP)

\begin{tabular}{lllllllll}
\hline \hline Panel A: Buy Transactions & 2004 & 2005 & 2006 & 2007 & 2008 & 2009 & 2010 & Total \\
\hline \hline Amount $\leq 15,000$ & 3,639 & 3,593 & 4,915 & 3,883 & 4,592 & 3,824 & 6,359 & 30,805 \\
$15,000<$ Amount $\leq 50,000$ & 778 & 715 & 558 & 767 & 620 & 427 & 820 & 4,685 \\
$50,000<$ Amount $\leq 100,000$ & 296 & 187 & 239 & 244 & 228 & 113 & 289 & 1,596 \\
Amount > 100,000 & 313 & 112 & 316 & 164 & 156 & 63 & 173 & 1,297 \\
Total & 5,026 & 4,607 & 6,028 & 5,058 & 5,596 & 4,427 & 7,641 & 38,383 \\
\hline \hline Panel B: Sell Transactions & 2004 & 2005 & 2006 & 2007 & 2008 & 2009 & 2010 & Total \\
\hline \hline Amount $\leq 15,000$ & 4,348 & 3,905 & 5,970 & 5,441 & 3,781 & 2,747 & 4,621 & 30,813 \\
$15,000<$ Amount $\leq 50,000$ & 883 & 819 & 650 & 658 & 693 & 656 & 768 & 5,127 \\
$50,000<$ Amount $\leq 100,000$ & 291 & 215 & 191 & 227 & 323 & 187 & 278 & 1,712 \\
Amount > 100,000 & 366 & 152 & 230 & 226 & 290 & 167 & 197 & 1,628 \\
Total & 5,888 & 5,091 & 7,041 & 6,552 & 5,087 & 3,757 & 5,864 & 39,280 \\
\hline \hline
\end{tabular}




\section{Table 4.3: Top Ten Traders During the 2004-2010 Period}

This table presents the politicians (members of the U.S. House, Senate and Executive Branch) who trade the most frequently (top traders) during the 2004-2010 period. Panel A presents the top 10 traders on the buy side along with their number of transactions and the percentage of the transactions they carry out in the buy sample. Similarly, Panel B presents the top 10 traders on the sell side along with their number of transactions and the percentage of the transactions they carry out in the sell sample.

Raw Data Source: Center for Responsive Politics (CRP)

\begin{tabular}{lllll}
\hline \hline Panel A: Top Buyers & Rank & Name & Number & Percent (\%) \\
\hline \hline & 1 & Michael McCaul & 5,572 & 14.82 \\
& 2 & Lamar Smith & 2,235 & 5.95 \\
& 3 & John Kerry & 2,185 & 5.81 \\
& 4 & Vernon Buchanan & 1,854 & 4.93 \\
& 5 & Kenny E. Marchant & 1,805 & 4.80 \\
& 6 & Kay R. Hagan & 1,539 & 4.09 \\
& 7 & Tom Osborne & 1,470 & 3.91 \\
& 8 & Jane Harman & 1,313 & 3.49 \\
& 9 & Jeff Bingaman & 1,264 & 3.36 \\
& 10 & Carolyn McCarthy & 1,080 & 2.87 \\
\hline \hline Panel B: Top Sellers & Rank & Name & Number & Percent (\%) \\
\hline \hline & 1 & Michael McCaul & 3,147 & 8.22 \\
& 2 & Kenny E. Marchant & 2,108 & 5.51 \\
& 3 & John Kerry & 2,022 & 5.28 \\
& 4 & Lamar Smith & 1,825 & 4.77 \\
& 5 & Jane Harman & 1,751 & 4.58 \\
6 & Vernon Buchanan & 1,713 & 4.48 \\
& 7 & Carolyn McCarthy & 1,709 & 4.47 \\
8 & Jeff Bingaman & 1,533 & 4.01 \\
9 & Tom Osborne & 1,166 & 3.05 \\
10 & Jim Moran & 1,089 & 2.85 \\
\hline \hline
\end{tabular}




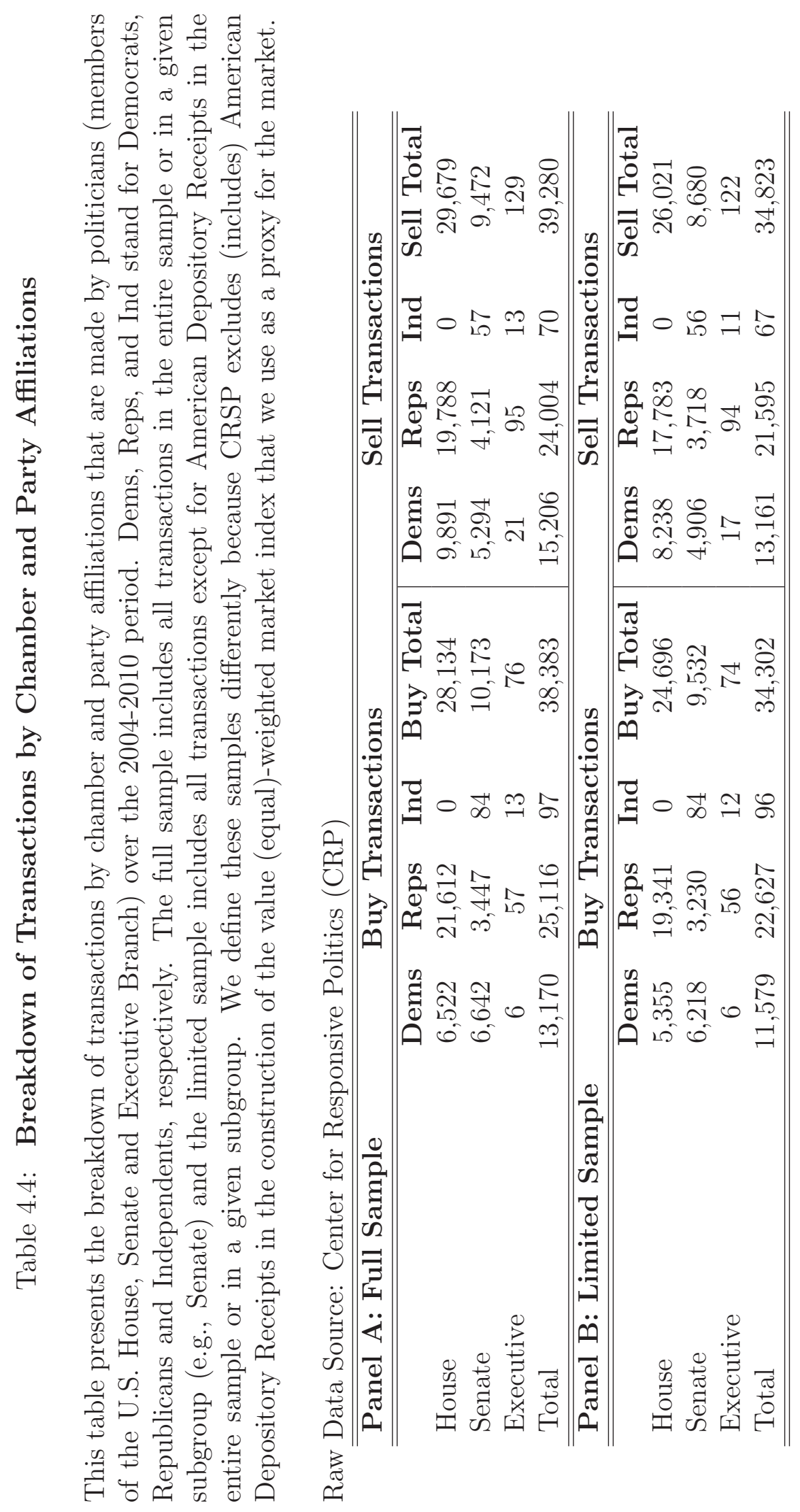




\section{Table 4.5: Descriptive Statistics}

This table presents the descriptive statistics of the variables used in the regression analysis over the 2004M01-2010M12 period. PTI is the person-based trading index constructed by Eq. (1) from the transactions data provided by Center for Responsive Politics. EREW (ERVW) is the excess returns, $100^{*}$ [raw market returns minus one-month T-bill rate], on the CRSP equal (value)-weighted market index. DSpread is the default spread (rate on BAA-corporate debt minus rate on AAA-corporate debt), TSpread is the term spread (10 year T-bond rate minus 3 month T-bill rate), and EP_Ratio is the earnings price ratio (log of 12 month moving sum of S\&P 500 earnings minus log of price). *, **, *** denote the 10,5 , and $1 \%$ significance level, respectively.

Univariate Analysis

\begin{tabular}{llllll}
\hline Variables & Mean & Median & St Dev & Min & Max \\
\hline PTI & -0.0119 & 0.0007 & 0.1568 & -0.5092 & 0.3562 \\
$E R E W(\%)$ & 0.6395 & 1.1308 & 5.7789 & -20.6022 & 19.2660 \\
$E R V W(\%)$ & 0.3734 & 0.9363 & 4.7432 & -18.5403 & 10.9259 \\
DSpread $(\%)$ & 1.1864 & 0.9500 & 0.6231 & 0.6200 & 3.3800 \\
TSpread $(\%)$ & 1.8389 & 2.2050 & 1.3189 & -0.3800 & 3.7000 \\
EP_Ratio & -0.6613 & -0.5128 & 0.3847 & -1.9724 & -0.3531 \\
\hline
\end{tabular}

Correlation Analysis

\begin{tabular}{lllllll}
\hline Variables & $P T I$ & $E R E W(\%)$ & $E R V W(\%)$ & DSpread $(\%)$ & TSpread $(\%)$ & EP_Ratio \\
\hline PTI & 1.0000 & & & & & \\
EREW $(\%)$ & 0.02 & 1.0000 & & & & \\
& $(0.16)$ & & & & & \\
$\operatorname{ERVW}(\%)$ & -0.03 & $0.95^{* * *}$ & 1.0000 & & & \\
& $(-0.26)$ & $(26.41)$ & & & & \\
DSpread $(\%)$ & 0.16 & -0.05 & -0.16 & 1.0000 & & \\
& $(1.43)$ & $(-0.43)$ & $(-1.46)$ & & & \\
TSpread $(\%)$ & $0.22^{* *}$ & 0.04 & -0.01 & $0.33^{* * *}$ & 1.0000 & \\
& $(2.06)$ & $(0.40)$ & $(-0.11)$ & $(3.14)$ & & \\
EP_Ratio & -0.03 & $-0.26^{* *}$ & $-0.21^{*}$ & -0.04 & $-0.61^{* * *}$ & 1.0000 \\
& $(-0.30)$ & $(-2.41)$ & $(-1.99)$ & $(-0.34)$ & $(-7.04)$ & \\
\hline
\end{tabular}




\section{Table 4.6: Aggregate Congressional Trading and Excess Market Returns}

This table reports the regression results on the predictive ability of aggregate congressional trading over the 2004M01-2010M12 period with all transactions included. The key explanatory variable, PTI, is the person-based trading index constructed by Eq. (1) from the transactions data provided by Center for Responsive Politics. The dependent variable, EREW (ERVW), is the excess returns, 100*[raw returns minus one-month T-bill rate], on the CRSP equal (value)-weighted market index. DSpread is the default spread (rate on BAA-corporate debt minus rate on AAA-corporate debt), TSpread is the term spread (10 year T-bond rate minus 3 month T-bill rate), and EP_Ratio is the earnings price ratio (log of 12 month moving sum of S\&P 500 earnings minus log of price). Heteroskedasticity and autocorrelation (HAC) robust t-statistics are provided in the parenthesis. ${ }^{*}, * *, * * *$ denote the 10,5 , and $1 \%$ significance levels of one-tailed (two-tailed) t-test for PTI (the others). Intercepts are not presented to save space.

\begin{tabular}{|c|c|c|c|c|c|}
\hline Panel A: EREW & Model I & Model II & Model III & Model IV & \\
\hline$P T I_{t-1}$ & $\begin{array}{l}0.62 \\
(0.13)\end{array}$ & & & $\begin{array}{l}0.59 \\
(0.14)\end{array}$ & \\
\hline$P T I_{t-2}$ & & $\begin{array}{l}8.18^{* *} \\
(2.28)\end{array}$ & & $\begin{array}{l}7.51^{* *} \\
(1.95)\end{array}$ & \\
\hline$P T I_{t-3}$ & & & $\begin{array}{l}10.45^{* * *} \\
(2.63)\end{array}$ & $\begin{array}{l}10.00^{* *} \\
(2.34)\end{array}$ & \\
\hline $\operatorname{Adj} R^{2}(\%)$ & -1.21 & 3.37 & 6.27 & 7.88 & \\
\hline Panel B: ERVW & Model I & Model II & Model III & Model IV & \\
\hline$P T I_{t-1}$ & $\begin{array}{l}-0.90 \\
(-0.26)\end{array}$ & & & $\begin{array}{l}-1.67 \\
(-0.55)\end{array}$ & \\
\hline$P T I_{t-2}$ & & $\begin{array}{l}9.01^{* *} \\
(2.23)\end{array}$ & & $\begin{array}{l}8.29^{* *} \\
(2.07)\end{array}$ & \\
\hline$P T I_{t-3}$ & & & $\begin{array}{l}8.49^{* *} \\
(2.06)\end{array}$ & $\begin{array}{l}7.34^{* *} \\
(1.75)\end{array}$ & \\
\hline $\operatorname{Adj} R^{2}(\%)$ & -1.17 & 5.43 & 4.66 & 7.80 & \\
\hline Panel C: EREW & Model I & Model II & Model III & Model IV & Model V \\
\hline$P T I_{t-2}$ & $\begin{array}{l}7.55^{* *} \\
(1.97)\end{array}$ & $\begin{array}{l}8.17^{* *} \\
(1.93)\end{array}$ & $\begin{array}{l}7.83^{* *} \\
(1.90)\end{array}$ & $\begin{array}{l}6.95^{* *} \\
(2.06)\end{array}$ & $\begin{array}{l}8.28^{* *} \\
(2.24)\end{array}$ \\
\hline$P T I_{t-3}$ & $\begin{array}{l}9.97^{* *} \\
(2.34)\end{array}$ & $\begin{array}{l}10.36^{* *} \\
(2.30)\end{array}$ & $\begin{array}{l}10.19^{* *} \\
(2.28)\end{array}$ & $\begin{array}{l}8.95^{* *} \\
(2.12)\end{array}$ & $\begin{array}{l}9.61^{* *} \\
(2.24)\end{array}$ \\
\hline DSpread & & $\begin{array}{l}-0.97 \\
(-0.45)\end{array}$ & & & $\begin{array}{l}-0.31 \\
(-0.15)\end{array}$ \\
\hline TSpread & & & $\begin{array}{l}-0.19 \\
(-0.33)\end{array}$ & & $\begin{array}{l}-1.08 \\
(-1.48)\end{array}$ \\
\hline EP_Ratio & & & & $\begin{array}{l}-3.07^{* *} \\
(-2.27)\end{array}$ & $\begin{array}{l}-5.24^{* *} \\
(-1.94)\end{array}$ \\
\hline $\operatorname{Adj} R^{2}(\%)$ & 9.04 & 8.96 & 8.05 & 12.09 & 14.28 \\
\hline Panel D: ERVW & Model I & Model II & Model III & Model IV & Model V \\
\hline$P T I_{t-2}$ & $\begin{array}{l}8.04^{* *} \\
(1.99)\end{array}$ & $\begin{array}{l}9.14^{* *} \\
(2.03)\end{array}$ & $\begin{array}{l}8.93^{* *} \\
(2.03)\end{array}$ & $\begin{array}{l}7.43^{* *} \\
(1.90)\end{array}$ & $\begin{array}{l}9.39^{* *} \\
(2.17)\end{array}$ \\
\hline$P T I_{t-3}$ & $\begin{array}{l}7.45^{* *} \\
(1.77)\end{array}$ & $\begin{array}{l}8.01^{* *} \\
(1.85)\end{array}$ & $\begin{array}{l}8.15^{* *} \\
(1.87)\end{array}$ & $\begin{array}{l}6.56^{*} \\
(1.55)\end{array}$ & $\begin{array}{l}7.48^{* *} \\
(1.78)\end{array}$ \\
\hline DSpread & & $\begin{array}{l}-1.68 \\
(-1.10)\end{array}$ & & & $\begin{array}{l}-1.11 \\
(-0.81)\end{array}$ \\
\hline TSpread & & & $\begin{array}{l}-0.44 \\
(-0.89)\end{array}$ & & $\begin{array}{l}-0.90 \\
(-1.55)\end{array}$ \\
\hline EP_Ratio & & & & $\begin{array}{l}-1.83^{* *} \\
(-2.28)\end{array}$ & $\begin{array}{l}-3.62^{* *} \\
(-2.07)\end{array}$ \\
\hline $\operatorname{Adj} R^{2}(\%)$ & 8.74 & 12.42 & 8.95 & 9.73 & 15.72 \\
\hline
\end{tabular}


Table 4.7: Industry Level Congressional Trading and Excess Market Returns

This table provides the estimation results over the 2004M01-2010M12 period from the pooled and Fama-MacBeth (1973) type regressions with the aggregate congressional trading measured at 12 different industry levels. The key explanatory variable, PTI, is the person-based trading index constructed by Eq. (1) from the transactions data provided by Center for Responsive Politics. The dependent variable, EREWIP (ERVWIP), is the excess returns, $100 *$ [raw industry returns minus one-month T-bill rate], on equal (value)weighted industry portfolio. $D V$ stands for the dependent variable. The t-statistics (in parenthesis) are robust to within-industry correlations in Panel A. *,**, *** denote the 10,5 , and $1 \%$ significance levels, respectively. We do two-tailed t-test for all coefficients. Industry fixed effects and intercepts are not presented to save space.

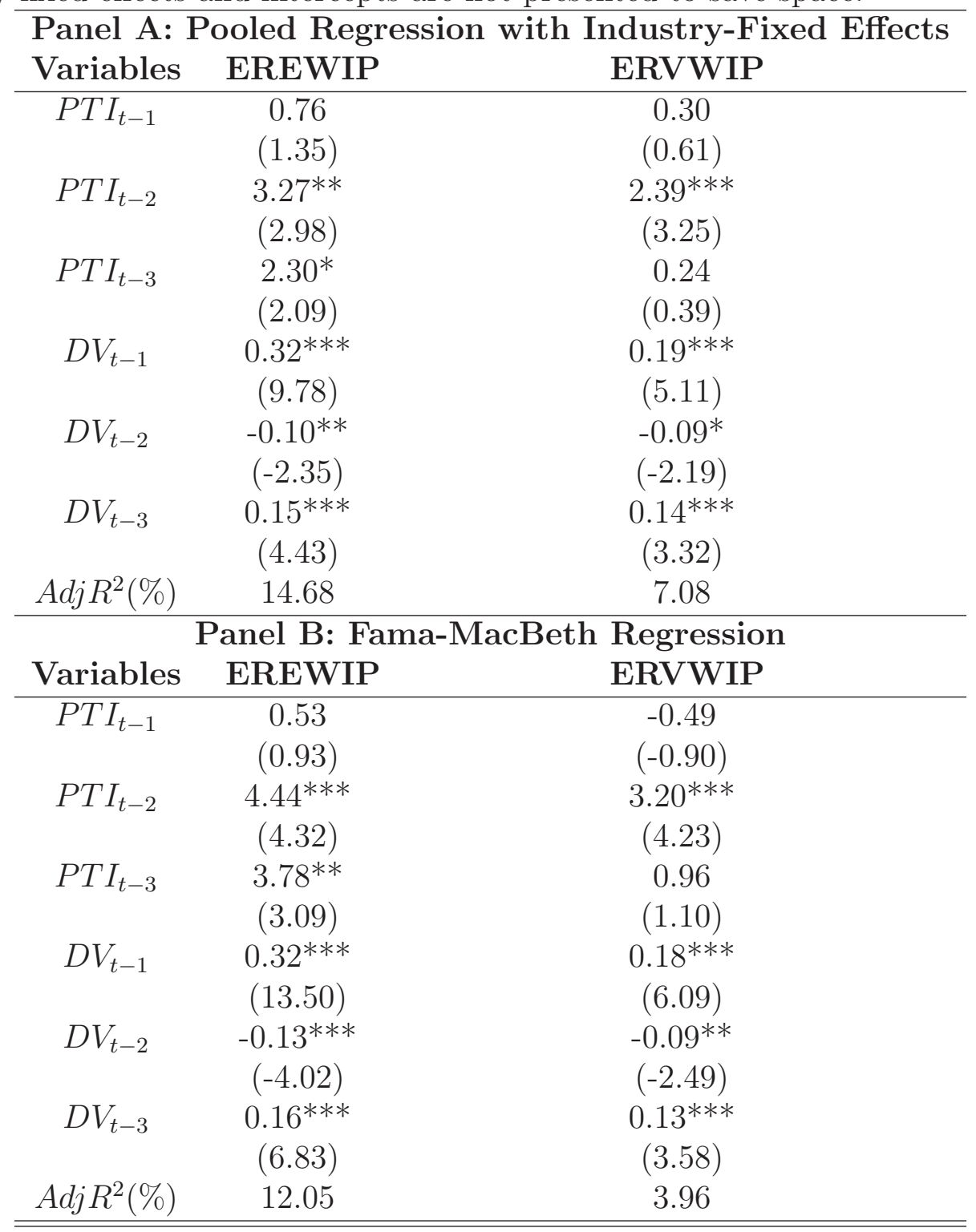




\section{Table 4.8: U.S. House and U.S. Senate}

This table summarizes the regression analysis for U.S. House and Senate over the 2004M01-2010M12 period. PTI is person-based trading index (Equation 1). EREW $(E R V W)$ is excess returns on CRSP equal (value)-weighted market index. DSpread is default spread (BAA-corporate debt yield minus AAAcorporate debt yield), TSpread is term spread (10 year T-bond yield minus 3 month T-bill rate), and EP_Ratio is earnings price ratio (log of 12 month moving sum of $\mathrm{S} \& \mathrm{P} 500$ earnings minus log of price). HAC robust t-statistics are in the parenthesis. ${ }^{*}, * *, * * *$ denote the 10,5 , and $1 \%$ significance levels of one-tailed (two-tailed) t-test for PTI (the rest). Intercepts are not presented to save space.

\begin{tabular}{|c|c|c|c|c|c|c|}
\hline Panel/Chamber/Dep.Var. & Variable & Model I & Model II & Model III & Model IV & Model V \\
\hline \multirow[t]{10}{*}{ A/House/ EREW } & $P T I_{t-2}$ & $\begin{array}{l}7.16^{* *} \\
(2.06)\end{array}$ & $\begin{array}{l}7.93^{* *} \\
(198)\end{array}$ & $\begin{array}{l}7.15^{* *} \\
(200)\end{array}$ & $\begin{array}{l}7.07^{* * *} \\
(252)\end{array}$ & $\begin{array}{l}7.87^{* * *} \\
(245)\end{array}$ \\
\hline & $P T I_{t-3}$ & $8.29^{* *}$ & $8.90^{* *}$ & $8.28^{* *}$ & $7.62^{* *}$ & $7.94^{* *}$ \\
\hline & & $(1.87)$ & $(1.86)$ & $(1.84)$ & $(1.80)$ & $(1.82)$ \\
\hline & DSpread & & -1.17 & & & -0.71 \\
\hline & & & $(-0.54)$ & & & $(-0.37)$ \\
\hline & TSpread & & & 0.02 & & -0.77 \\
\hline & & & & $(0.03)$ & & $(-1.07)$ \\
\hline & EP_Ratio & & & & $-3.42^{* *}$ & $-5.06^{*}$ \\
\hline & & & & & $(-2.41)$ & $(-1.86)$ \\
\hline & $\operatorname{Adj} R^{2}(\%)$ & 8.81 & 9.19 & 7.63 & 12.99 & 14.19 \\
\hline \multirow[t]{11}{*}{ B/House/ ERVW } & $P T I_{t-2}$ & $6.95^{* *}$ & $8.14^{* *}$ & $7.10^{* *}$ & $6.75^{* *}$ & $8.04^{* *}$ \\
\hline & & $(2.15)$ & $(2.12)$ & $(2.07)$ & $(2.27)$ & $(2.31)$ \\
\hline & $P T I_{t-3}$ & $5.26^{*}$ & $6.13^{*}$ & $5.37^{*}$ & $4.66^{*}$ & $5.32 *$ \\
\hline & & $(1.47)$ & $(1.52)$ & $(1.46)$ & $(1.31)$ & $(1.39)$ \\
\hline & DSpread & & -1.78 & & & -1.40 \\
\hline & & & $(-1.18)$ & & & $(-1.04)$ \\
\hline & TSpread & & & -0.19 & & -0.62 \\
\hline & & & & $(-0.42)$ & & $(-1.05)$ \\
\hline & EP_Ratio & & & & $-2.31^{* *}$ & $-3.65^{*}$ \\
\hline & & & & & $(-2.55)$ & $(-1.92)$ \\
\hline & $\operatorname{Adj}^{2}(\%)$ & 6.39 & 10.53 & 5.45 & 8.75 & 13.68 \\
\hline \multirow[t]{11}{*}{ C/Senate/ EREW } & $P T I_{t-2}$ & 2.78 & 2.78 & 2.77 & 2.02 & 2.36 \\
\hline & & $(0.95)$ & $(0.95)$ & $(0.92)$ & $(0.73)$ & $(0.87)$ \\
\hline & $P T I_{t-3}$ & -0.25 & -0.33 & -0.27 & -0.66 & -0.16 \\
\hline & & $(-0.07)$ & $(-0.09)$ & $(-0.07)$ & $(-0.17)$ & $(-0.04)$ \\
\hline & DSpread & & -0.34 & & & 0.24 \\
\hline & & & $(-0.14)$ & & & $(0.11)$ \\
\hline & TSpread & & & 0.02 & $-3.58^{* *}$ & -1.00 \\
\hline & & & & $(0.03)$ & $(-2.04)$ & $(-1.45)$ \\
\hline & EP_Ratio & & & & & $-5.52^{*}$ \\
\hline & & & & & & $(-1.85)$ \\
\hline & $\operatorname{Adj} R^{2}(\%)$ & -1.02 & -2.20 & -2.33 & 3.33 & 3.72 \\
\hline \multirow[t]{11}{*}{ D/Senate/ ERVW } & $P T I_{t-2}$ & 2.00 & 2.00 & 2.18 & 1.49 & 1.78 \\
\hline & & $(0.77)$ & $(0.79)$ & $(0.81)$ & $(0.59)$ & $(0.74)$ \\
\hline & $P T I_{t-3}$ & 0.85 & 0.61 & 1.00 & 0.51 & 0.68 \\
\hline & & $(0.31)$ & $(0.21)$ & $(0.36)$ & $(0.18)$ & $(0.22)$ \\
\hline & DSpread & & -1.15 & & & -0.70 \\
\hline & & & $(-0.67)$ & & & $(-0.45)$ \\
\hline & TSpread & & & -0.21 & & -0.77 \\
\hline & & & & $(-0.46)$ & & $(-1.53)$ \\
\hline & EP_Ratio & & & & $-2.37^{* *}$ & $-3.95^{*}$ \\
\hline & & & & & $(-2.02)$ & $(-1.93)$ \\
\hline & $\operatorname{Adj} R^{2}(\%)$ & -0.51 & 0.51 & -1.49 & 1.80 & 4.36 \\
\hline
\end{tabular}




\section{Table 4.9: Democrats (Dems) and Republicans (Reps)}

This table summarizes the estimation results for Democrats and Republicans over 2004M01-2010M12 period. $P T I$ is person-based trading index (Equation 1). EREW $(E R V W)$ is excess returns on CRSP equal (value)-weighted market index. DSpread is default spread (BAA-corporate debt yield minus AAAcorporate debt yield), TSpread is term spread (10 year T-bond yield minus 3 month T-bill rate), and EP_Ratio is earnings price ratio (log of 12 month moving sum of $\mathrm{S} \& \mathrm{P} 500$ earnings minus log of price). HAC robust t-statistics are in the parenthesis. ${ }^{*}, * *, * * *$ denote the 10,5 , and $1 \%$ significance levels of one-tailed (two-tailed) t-test for PTI (the rest). Intercepts are not presented to save space.

\begin{tabular}{|c|c|c|c|c|c|c|}
\hline Panel/Party/Dep.Var. & Variable & Model I & Model II & Model III & Model IV & Model V \\
\hline \multirow[t]{10}{*}{ A/Dems/ EREW } & $P T I_{t-2}$ & $5.33^{* *}$ & $5.34^{* *}$ & $5.40^{* *}$ & $5.26^{* *}$ & $6.71^{* * *}$ \\
\hline & & $(1.80)$ & $(1.83)$ & $(1.72)$ & (1.89) & $(2.40)$ \\
\hline & $P T I_{t-3}$ & 2.28 & $2.31^{*}$ & 2.37 & 2.23 & $4.17^{* *}$ \\
\hline & & (1.15) & (1.45) & (1.04) & (1.07) & $(2.24)$ \\
\hline & DSpread & & 0.06 & & & 1.34 \\
\hline & & & $(0.03)$ & & & $(0.69)$ \\
\hline & TSpread & & & -0.10 & & $-1.72^{* *}$ \\
\hline & & & & $(-0.17)$ & & $(-2.18)$ \\
\hline & EP_Ratio & & & & $-3.71^{* *}$ & $-7.12^{* *}$ \\
\hline & $\operatorname{Adj} R^{2}(\%)$ & 4.48 & 3.24 & 3.30 & 9.59 & 14.24 \\
\hline \multirow[t]{10}{*}{ B/Dems/ ERVW } & $P T I_{t-2}$ & $5.04^{* *}$ & $4.81^{* *}$ & $5.36^{* *}$ & $4.88^{* *}$ & $6.06^{* *}$ \\
\hline & & $(1.84)$ & $(1.85)$ & (1.87) & (1.81) & $(2.28)$ \\
\hline & $P T I_{t-3}$ & 1.64 & 1.21 & 1.98 & 1.50 & $2.82^{*}$ \\
\hline & & $(0.86)$ & $(0.83)$ & $(0.90)$ & $(0.77)$ & (1.49) \\
\hline & DSpread & & $\begin{array}{l}-0.83 \\
(-0.52)\end{array}$ & & & 0.26 \\
\hline & TSpread & & & -0.35 & & $-1.39^{* *}$ \\
\hline & & & & $(-0.65)$ & & $(-2.24)$ \\
\hline & EP_Ratio & & & & $-2.44^{* *}$ & $-5.21 * * *$ \\
\hline & & & & & $(-2.59)$ & $(-2.65)$ \\
\hline & $\operatorname{Adj}^{2}(\%)$ & 5.47 & 5.39 & 5.12 & 8.27 & 13.73 \\
\hline \multirow[t]{10}{*}{ C/Reps/ EREW } & $P T I_{t-2}$ & 1.80 & 3.98 & 1.89 & 0.89 & 2.83 \\
\hline & & $(0.45)$ & (1.11) & $(0.51)$ & $(0.24)$ & $(0.89)$ \\
\hline & $P T I_{t-3}$ & $8.38^{* *}$ & $10.53^{* *}$ & $8.44^{* *}$ & $6.99^{* *}$ & $8.40^{* *}$ \\
\hline & & $(1.85)$ & $(2.13)$ & (1.88) & (1.51) & (1.77) \\
\hline & DSpread & & $\begin{array}{l}-1.76 \\
(-071)\end{array}$ & & & -1.07 \\
\hline & TSpread & & & -0.06 & & -0.69 \\
\hline & & & & $(-0.12)$ & & $(-0.93)$ \\
\hline & EP_Ratio & & & & $-3.09^{*}$ & -4.35 \\
\hline & & & & & $(-1.82)$ & $(-1.49)$ \\
\hline & $\operatorname{Adj}^{2}(\%)$ & 3.90 & 5.52 & 2.67 & 6.82 & 8.07 \\
\hline \multirow[t]{8}{*}{ D/Reps/ ERVW } & $P T I_{t-2}$ & 1.90 & 5.13 & 2.21 & 1.19 & 4.26 \\
\hline & $P T I_{t-3}$ & $4.95 *$ & $\begin{array}{l}(1.03) \\
8.02^{* *}\end{array}$ & $5.15^{*}$ & $\begin{array}{l}(0.01) \\
3.84\end{array}$ & $6.41^{*}$ \\
\hline & & $(1.42)$ & $(1.92)$ & $(1.48)$ & $(1.06)$ & $(1.56)$ \\
\hline & DSpread & & $\begin{array}{l}-2.38 \\
(1.29)\end{array}$ & & & -1.90 \\
\hline & & & $(1.32)$ & & & $(-1.14)$ \\
\hline & TSpread & & & $\begin{array}{l}-0.20 \\
(-0.47)\end{array}$ & & $\begin{array}{l}-0.48 \\
(-0.80)\end{array}$ \\
\hline & EP_Ratio & & & & $-2.24^{*}$ & -2.98 \\
\hline & $\operatorname{Adj}^{2}(\%)$ & 0.63 & 7.05 & -0.36 & $\begin{array}{l}(-1.9 \\
2.54\end{array}$ & $\begin{array}{l}(-1.48) \\
8.04\end{array}$ \\
\hline
\end{tabular}




\section{Table 4.10: Aggregate Congressional Trading and Excess Market Returns}

This table reports the regression results on the predictive ability of aggregate congressional trading over the 2004M01-2010M12 period with all transactions included. The key explanatory variable, TTI, is the transaction-based trading index constructed by Eq. (5) from the transactions data provided by Center for Responsive Politics. The dependent variable, EREW $(E R V W)$, is the excess returns, 100* raw returns minus one-month T-bill rate], on the CRSP equal (value)-weighted market index. DSpread is the default spread (rate on BAA-corporate debt minus rate on AAA-corporate debt), TSpread is the term spread (10 year T-bond rate minus 3 month T-bill rate), and EP_Ratio is the earnings price ratio (log of 12 month moving sum of S\&P 500 earnings minus log of price). Heteroskedasticity and autocorrelation (HAC) robust t-statistics are provided in the parenthesis. ${ }^{*}, * *, * * *$ denote the 10,5 , and $1 \%$ significance levels of one-tailed (two-tailed) t-test for PTI (the others). Intercepts are not presented to save space.

\begin{tabular}{|c|c|c|c|c|c|}
\hline Panel A: EREW & Model I & Model II & Model III & Model IV & \\
\hline$T T I_{t-1}$ & $\begin{array}{l}1.57 \\
(0.29)\end{array}$ & & & $\begin{array}{l}-1.64 \\
(-0.34)\end{array}$ & \\
\hline$T T I_{t-2}$ & & $\begin{array}{l}8.96^{* *} \\
(2.23)\end{array}$ & & $\begin{array}{l}7.49^{* *} \\
(2.15)\end{array}$ & \\
\hline$T T I_{t-3}$ & & & $\begin{array}{l}10.21^{* *} \\
(2.09)\end{array}$ & $\begin{array}{l}9.01^{* *} \\
(1.89)\end{array}$ & \\
\hline $\operatorname{Adj} R^{2}(\%)$ & -1.03 & 5.48 & 7.45 & 9.54 & \\
\hline Panel B: ERVW & Model I & Model II & Model III & Model IV & \\
\hline$T T I_{t-1}$ & $\begin{array}{l}-0.27 \\
(-0.07)\end{array}$ & & & $\begin{array}{l}-3.15 \\
(-0.77)\end{array}$ & \\
\hline$T T I_{t-2}$ & & $\begin{array}{l}7.20^{* *} \\
(2.04)\end{array}$ & & $\begin{array}{l}6.49^{* *} \\
(1.91)\end{array}$ & \\
\hline$T T I_{t-3}$ & & & $\begin{array}{l}6.89^{* *} \\
(1.80)\end{array}$ & $\begin{array}{l}6.00^{*} \\
(1.62)\end{array}$ & \\
\hline $\operatorname{Adj} R^{2}(\%)$ & -1.22 & 4.57 & 4.07 & 6.33 & \\
\hline Panel C: EREW & Model I & Model II & Model III & Model IV & Model V \\
\hline$T T I_{t-2}$ & $\begin{array}{l}7.21^{* *} \\
(2.15)\end{array}$ & $\begin{array}{l}10.32^{* *} \\
(2.12)\end{array}$ & $\begin{array}{l}8.89^{* *} \\
(2.16)\end{array}$ & $\begin{array}{l}6.24^{* *} \\
(1.87)\end{array}$ & $\begin{array}{l}10.26^{* *} \\
(2.11)\end{array}$ \\
\hline$T T I_{t-3}$ & $\begin{array}{l}8.75^{* *} \\
(1.92)\end{array}$ & $\begin{array}{l}11.15^{* *} \\
(2.02)\end{array}$ & $\begin{array}{l}10.31^{* *} \\
(1.96)\end{array}$ & $\begin{array}{l}7.42^{* *} \\
(1.54)\end{array}$ & $\begin{array}{l}10.46^{* *} \\
(1.84)\end{array}$ \\
\hline DSpread & & $\begin{array}{l}-2.45 \\
(-1.13)\end{array}$ & & & $\begin{array}{l}-1.62 \\
(-0.82)\end{array}$ \\
\hline TSpread & & & $\begin{array}{l}-0.71 \\
(-1.03)\end{array}$ & & $\begin{array}{l}-1.16 \\
(-1.56)\end{array}$ \\
\hline EP_Ratio & & & & $\begin{array}{l}-2.00 \\
(-1.37)\end{array}$ & $\begin{array}{l}-3.62 \\
(-1.47)\end{array}$ \\
\hline $\operatorname{Adj} R^{2}(\%)$ & 10.48 & 14.96 & 11.48 & 10.89 & 17.25 \\
\hline Panel D: ERVW & Model I & Model II & Model III & Model IV & Model V \\
\hline$T T I_{t-2}$ & $\begin{array}{l}5.84^{* *} \\
(1.89)\end{array}$ & $\begin{array}{l}9.65^{* *} \\
(2.03)\end{array}$ & $\begin{array}{l}8.07^{* *} \\
(2.06)\end{array}$ & $\begin{array}{l}5.11^{*} \\
(1.60)\end{array}$ & $\begin{array}{l}10.26^{* *} \\
(2.04)\end{array}$ \\
\hline$T T I_{t-3}$ & $\begin{array}{l}5.46^{*} \\
(1.55)\end{array}$ & $\begin{array}{l}8.18^{* *} \\
(1.89)\end{array}$ & $\begin{array}{l}7.53^{* *} \\
(1.80)\end{array}$ & $\begin{array}{l}4.48 \\
(1.14)\end{array}$ & $\begin{array}{l}8.40^{* *} \\
(1.76)\end{array}$ \\
\hline DSpread & & $\begin{array}{l}-2.87^{*} \\
(-1.93)\end{array}$ & & & $\begin{array}{l}-2.30 \\
(-1.64)\end{array}$ \\
\hline TSpread & & & $\begin{array}{l}-0.82 \\
(-1.36)\end{array}$ & & $\begin{array}{l}-0.95^{*} \\
(-1.72)\end{array}$ \\
\hline EP_Ratio & & & & $\begin{array}{l}-1.25 \\
(-1.14)\end{array}$ & $\begin{array}{l}-2.09 \\
(-1.23)\end{array}$ \\
\hline $\operatorname{Adj}^{2}(\%)$ & 6.49 & 16.76 & 9.16 & 6.11 & 18.29 \\
\hline
\end{tabular}




\section{Chapter 5}

\section{Conclusion}

This dissertation documents that members of Congress (politicians) are informed traders in that the stocks that they buy go up in value and the stocks that they sell decline in value. They trade on such private information that their portfolios earn short-term abnormal returns. Party membership, committee membership (a proxy for power), and trading experience are important determinants of abnormal returns on congressional stock portfolios. In particular, the unsophisticated powerful members of the Republican Party have the best performing portfolios with short-term annualized abnormal returns exceeding $34 \%$.

Informed trading extends beyond members of Congress. We present evidence that spouses of politicians also trade on private information generating short-term abnormal returns. These short-term abnormal returns are higher for the spouses of powerful politicians. Also, trading behavior of politicians explains a big part of abnormal returns on spousal portfolios. When politicians have their own trading accounts, their spouses' portfolios outperform the market. On the other hand, when politicians do not have their own trading accounts (i.e., politicians who do not trade themselves) their spouses' portfolios mostly have mediocre performance. 
We find that the nature of congressional trading is not limited to firm-specific information. We present evidence that politicians, similar to corporate insiders, also trade on macroeconomic information. In other words, their trades are driven by economy-wide information to a certain extent. Aggregate analysis of congressional stock trades reveals that both Republicans and Democrats trade on economy-wide information. Interestingly, the first essay clearly shows that it is only Republicans who trade on value-relevant firm-specific information, and there are no abnormal returns on the portfolios of Democrats. Combining the results of portfolio analysis and aggregate analysis helps us conclude that Republicans are informed traders with respect to both firm-specific and macroeconomic information whereas Democrats are informed traders only with respect to macroeconomic information. Overall, the results in this dissertation essays suggest that members of Congress are better than average investors when it comes to investing in common stocks.

We hope that future research sheds light on the channels through which members of Congress receive firm-specific and macroeconomic information. It will be interesting to examine if politicians are more likely to have private political information on firms that they directly regulate. Investigating whether politicians from states with large economies are more likely to trade on macroeconomic information than those from states with small economies is another interesting question for future research. 


\section{References}

[1] Amihud, Y., 2002. Illiquidity and stock returns: cross-section and time-series effects. Journal of Financial Markets 5, 31-56.

[2] Belo, F., Gala, V.D., Li, J., 2013. Government spending, political cycles, and the cross section of stock returns. Journal of Financial Economics 107 (2), 305-324.

[3] Berkman, H., Koch, P.D., Westerholm, P.J., 2013. Informed trading through the accounts of children. Journal of Finance (forthcoming).

[4] Chowdhury, M., Howe, J.S., Lin, J.C., 1993. The relation between aggregate insider transactions and stock market returns. Journal of Financial and Quantitative Analysis 28, 431-437.

[5] Cohen, L., Coval, J., Malloy, C., 2011. Do powerful politicians cause corporate downsizing? Journal of Political Economy 119 (6), 1015-1060.

[6] Cohen, L., Malloy, C., Pomorski, L., 2012. Decoding inside information. Journal of Finance 67 (3), 1009-1043.

[7] Cooper, M.J., Gulen, H., Ovtchinnikov, A.V., 2010. Corporate political contributions and stock returns. Journal of Finance 65 (2), 687-724.

[8] Edwards, K.M., Stewart III, C., 2006. The value of committee assignments in Congress since 1994. Working Paper.

[9] Eggers, A., Hainmueller, J., 2013 (a).Capitol losses: The mediocre performance of congressional stock portfolios, 2004-2008. Journal of Politics.

[10] Eggers, A., Hainmueller, J., 2013(b). Political Capital: Corporate connections and stock investments in the U.S. Congress, 2004-2008. Working paper, available at http://papers.ssrn.com/sol3/papers.cfm?abstract_id=1967628.

[11] Faccio, M., Parsley, D.C., 2009. Sudden deaths: taking stock of geographic ties. Journal of Financial and Quantitative Analysis 44, 683-718.

[12] Fama, E. F., 1998. Market efficiency, long-term results and behavioral finance. Journal of Financial Economics 49, 283-306.

[13] Fama, E., French, K., 1992. The cross-section of expected stock returns. Journal of Finance 47 (2), 427-465. 
[14] Fama, E., French, K., 1993. Common risk factors in returns on stocks and bonds. Journal of Financial Economics 33, 3-56.

[15] Fama, E., French, K., 1997. Industry cost of equity. Journal of Financial Economics 43, 153-193.

[16] Fama, E., French, K., 2008. Dissecting Anomalies. Journal of Finance 63(4), 1653-1678.

[17] Fama, E., MacBeth, J., 1973. Risk, return, and equilibrium: Empirical tests. Journal of Political Economy 81, 607-636.

[18] Gao, M., Huang, J., 2011. Capitalizing on capital hill: Informed trading by hedge fund managers. Working Paper, available at http://papers.ssrn.com/sol3/papers.cfm?abstract_id=1707181

[19] Goldman, E., Rocholl, J., So, J., 2009. Do politically connected boards affect firm value. Review of Financial Studies 22, 2331-2360.

[20] Howe, J.S., Unlu, E., Yan, X., 2009. The predictive content of aggregate analyst recommendations. Journal of Accounting Research 47, 799-821.

[21] Ivkovic, Z., Weisbenner, S., 2005. Local does as local is: Information content of the geography of individual investors' common stock investments. Journal of Finance 60(1), 267-306.

[22] Jeng, L.A., Metrick, A., Zeckhauser, R., 2003. Estimating returns to insider trading: A performance-evaluation perspective. Review of Economics and Statistics 85(2), 453-471.

[23] Jiang, X., Zaman, M., 2010. Aggregate insider trading: Contrarian beliefs or superior information. Journal of Banking and Finance 34, 1225-1236.

[24] Karadas, S., 2014(a). Informed Trading at Capitol Hill: Evidence from Congressional Trading. Working Paper.

[25] Karadas, S., 2014(b). Informed Trading through Family Members: Evidence from Congressional Trading. Working Paper.

[26] Karadas, S., 2014(c). Aggregate congressional trading and stock market returns. Working Paper.

[27] Khuzami, R., 2011. Statement to the House, Committee on Financial Services. The Stop Trading Congressional Act, Testimony, December 6, 2011. Available at: http://financialservices.house.gov/UploadedFiles/120611khuzami.pdf

[28] Kim, C., Pantzalis, C., Park, J.C., 2012. Political geography and stock returns: The value and risk implications of proximity to political power. Journal of Financial Economics 106 (1), 196-228.

[29] Kolari, J.W., Pynnonen, S., 2010. Event study testing cross-sectional correlation of abnormal returns. Review of Financial Studies 23, 3996-4025.

[30] Kothari, S.P., Warner, J.B., 2007. Econometrics of event studies. Handbook of Corporate Finance 1. 
[31] Lakonishok, J., Lee, I., 2001. Are insider trades informative? Review of Financial Studies 14(1), 79-111.

[32] Loughran, T., Ritter, J.R., 2000. Uniformly least powerful tests of market efficiency. Journal of Financial Economics 55(3), 361-389.

[33] Lyon, J.D., Barber, B.M., Tsai, C., 1999. Improved methods for tests for long-run abnormal stock returns. Journal of Finance 54 (1), 165-201.

[34] Mitchell, M.L., Stafford, E. Managerial decisions and long-term stock price performance. Journal of Business 73, 287-320.

[35] Nagy, D.M., 2011. Statement to the House, Committee on Financial Services. the Stop Trading Congressional Act, Testimony, December 6, 2011. Available at: http://financialservices.house.gov/UploadedFiles/120611nagy.pdf

[36] Odean, T., 1999. Do investors trade too much? American Economic Review 89-5, 1279-1298.

[37] Pastor, L., Stambaugh, R. F., 2003. Liquidity risk and expected stock returns. Journal of Political Economy 111(3), 642-685.

[38] Schweizer, P., 2011. Throw them all out: How politicians and their friends get rich off insider stock tips, land deals, and cronyism that would send the rest of us to prison. Houghton Mifflin Harcourt, Boston.

[39] Seasholes, M.S., Zhu, N., 2010. Individual investors and local bias. Journal of Finance $65,1988-2010$.

[40] Seru, A., Shumway, T., Stoffman, N., 2009. Learning by trading. Review of Financial Studies 23, 705-739.

[41] Seyhun, H.N., 1988. The information content of aggregate insider trading. Journal of Business 61, 1-24.

[42] Seyhun, H.N., 1992. Why does aggregate insider trading predict future stock returns. Quarterly Journal of Economics 107, 1303-1331.

[43] Seyhun, H. N., 2000. Investment intelligence from insider trading. MIT Press.

[44] Slaughter, L.M., 2011. Statement to the House, Committee on Financial Services. the Stop Trading Congressional Act, Testimony, December 6, 2011. Available at: http://financialservices.house.gov/UploadedFiles/120611slaughter.pdf

[45] Stewart III, C., 2012. The Value of committee assignments since 1994. MIT working paper 2012-7, available at http://papers.ssrn.com/sol3/papers.cfm?abstract_id=2035632.

[46] Stewart III, C., Woon, J., 2011. Congressional committee assignments, 103rd to 112th Congresses, 1993-2011.

[47] Tahoun, A., Van Lent, L., 2010. The personal wealth interests of politicians and government intervention in the economy. Working paper available at http://papers.ssrn.com/sol3/papers.cfm?abstract_id=1570219. 
[48] Welch, I., Goyal, A., 2007. A comprehensive look at the empirical performance of equity premium prediction. Review of Financial Studies 21, 1455-1508.

[49] Ziobrowski, A.J., Cheng, P., Boyd, J.W., Ziobrowski, B.J., 2004. Abnormal returns from the common stock investments of the U.S. Senate. Journal of Financial and Quantitative Analysis 39, 661-676.

[50] Ziobrowski, A.J., Boyd, J.W., Cheng, P., Ziobrowski, B.J., 2011. Abnormal returns from the common stock investments of the members of the U.S. House of Representatives. Business and Politics 13 (1)-4. 